UNIVERSIDADE DE SÃO PAULO

FACULDADE DE EDUCAÇÃO

DANIELA WALDMAN TEPERMAN

FAMÍLIA, PARENTALIDADE E ÉPOCA:

UM "NÓS" QUE NÃO EXISTE

SÃO PAULO

2012 
DANIELA WALDMAN TEPERMAN

\title{
FAMÍLIA, PARENTALIDADE E ÉPOCA: UM "NÓS” QUE NÃO EXISTE
}

\author{
Tese apresentada ao Programa de \\ Pós-Graduação da Faculdade de Educação \\ da Universidade de São Paulo, para \\ obtenção do título de Doutor em Educação. \\ Área de Concentração: \\ Psicologia e Educação \\ Orientador: Prof. Dr. Rinaldo Voltolini
}


Autorizo a reprodução e divulgação total ou parcial deste trabalho, por qualquer meio convencional ou eletrônico, para fins de estudo e pesquisa, desde que citada a fonte.

Catalogação na Publicação

Serviço de Biblioteca e Documentação

Faculdade de Educação da Universidade de São Paulo

156.42 Teperman, Daniela Waldman

T314f Família, parentalidade e época: um "nós" que não existe / Daniela

Waldman Teperman ; orientação Rinaldo Voltolini. São Paulo : s.n., 2012 .

$198 \mathrm{p}$.

Tese (Doutorado - Programa de Pós-Graduação em Educação.

Área de Concentração : Psicologia e Educação) - Faculdade de

Educação da Universidade de São Paulo)

1. Psicanálise 2. Família 3. Parentalidade 4. Sujeito 5.

Contemporaneidade 6. Educação I. Voltolini, Rinaldo, orient. 
DANIELA WALDMAN TEPERMAN

\section{FAMÍLIA, PARENTALIDADE E ÉPOCA: UM "NÓS" QUE NÃO EXISTE}

Tese apresentada ao Programa de Pós-Graduação da Faculdade de Educação da Universidade de São Paulo, para obtenção do título de Doutor em Educação.

Área de Concentração: Psicologia e Educação

Banca Examinadora

Prof. Dr. Instituição:

Assinatura:

Prof. Dr. Instituição:

Assinatura:

Prof. Dr. Instituição:

Assinatura:

Prof. Dr. Instituição:

Assinatura:

Prof. Dr. Instituição:

Assinatura:

SÃO PAULO

2012 


\section{AGRADECIMENTOS}

A meu orientador, Rinaldo Voltolini, pela confiança, pelo respeito e pela tranqüilidade, fundamentais para que eu pudesse suportar o tempo - tão demorado! - de compreender, e para que os "achados" surgissem nesta pesquisa.

A Caty Koltai, professora querida desde os tempos da graduação, pelas contribuições preciosas e instigantes no exame de qualificação, decisivas para os destinos desta pesquisa.

A querida Leda Bernardino, que testemunha um modo possível de pensar a clínica e de circular entre os psicanalistas e entre os profissionais de outras áreas; amiga desde o mestrado, leitora delicada e dedicada no exame de qualificação.

A Inês Loureiro, pela disponibilidade, pela generosidade e pelo cuidado impressionantes na leitura e nos comentários deste trabalho e por me fazer lembrar porque escolhi a pesquisa acadêmica.

A minha mãe, Marta, de quem herdei, não sem relutar um pouco, algumas inquietações e o especial interesse por aqueles que "têm um brilho no olhar".

A meu pai, Rogério, que faz tanta diferença na minha vida, que me acompanha sempre de perto.

A Luisa, que me mostrou desde os primeiros dias de vida como uma filha pode ser tão amada e tão diferente da mãe, e que tem me mostrado que é possível inventar a própria família de outro jeito, do seu jeito, que eu respeito e admiro.

Aos meus irmãos André, Fernando, Ricardo e Julia, tão queridos! A Maria Helena, que faz parte da minha família desde sempre. A Dani, minha cunhada querida, Ricardo, meu primeiro sobrinho, e Dudu, o mais novo integrante da família. E a Bia, cunhada-parceira em tantos momentos.

A Renata Petri, pela amizade preciosa, construída aos poucos, fortalecida ao longo dos anos.

A Luciana Pires, amiga-irmã, que é parte da minha história, por tantos bons momentos partilhados.

A Luciana Annunziata Lopes, pela amizade de uma vida inteira.

A Ilana Katz Fragelli amiga querida, comadre, e que, junto com Guto, Miguel e Deco, é também minha família.

A Débora Valentini, por sua admirável integridade, por seu modo de mostrar-se amiga.

A Heloisa Prado, por me mostrar com tanta precisão como posição ética e estilo podem andar tão bem juntos. 
A Domingos Infante, pela transmissão viva, pela generosidade ao partilhar suas construções fundamentadas na pesquisa e na clínica e por marcar sempre os riscos das generalizações na clínica psicanalítica, recomendação que me acompanha sempre e que procurei seguir à risca nesta pesquisa.

A Ethel Akkerman, pela amizade, pelo carinho e por acompanhar-me de perto no dia a dia e na confecção deste trabalho. E às minhas queridas parceiras de consultório Maria Elisa Pessoa Labaki e Margaret Cross Silva.

Aos colegas do Núcleo de Estudos e Pesquisas em Psicanálise com Crianças: Adriana Barbosa Pereira, Alexandre de Bellis, Carina Faria, Cecília Santana, Domingos Infante, Ilana Katz Fragelli, Julieta Jerusalinky, Marcia Funabashi, Rejane Rubino, Renata Guarido e Renata Petri, pela experiência clínica compartilhada, pelas discussões instigantes e pelos comentários preciosos.

A Tatiana Mazzarella, com quem partilho inquietações na clínica e na transmissão.

A Suzana Fontenelle, amiga carinhosa, parceira em caminhadas sempre animadas por discussões temáticas.

A Bel Abreu, pela atenção, pelo cuidado e pela companhia durante o doutorado.

A Maria Luiza Bonanata da Rocha pela revisão criteriosa e pelo cuidado de não modificar meu estilo de escrita.

A CAPES, que financiou esta pesquisa. 
"Todas as famílias felizes são parecidas; as infelizes o são cada uma à sua maneira"

Leon Tolstoi. 


\section{RESUMO}

TEPERMAN, D. W. Família, parentalidade e época: um "nós" que não existe. Tese (doutorado). Faculdade de Educação, Universidade de São Paulo, São Paulo, 2012.

"Parentalidade" é um neologismo que vem ganhando consistência nos últimos anos e que tende a substituir o termo "família”. É possível localizar essa preocupação em diversos autores, de diferentes disciplinas, extraindo da possível substituição diferentes consequências. Haveria mesmo nesse novo termo e, nos discursos que lhe são subjacentes, essa pretensão? Sustentar-se-ia tal pretensão na leitura de que a família vive uma crise sem precedentes na atualidade? A parentalidade implicaria um risco para a transmissão familiar? Foi a partir desses interrogantes que iniciei esta pesquisa. $\mathrm{O}$ incômodo inicial foi provocado pelo entendimento de que o novo termo seria indissociável da intervenção do especialista no campo da família e pela desconfiança de que fincaria suas bases na indiferenciação e na assepsia na transmissão familiar. A investigação das origens desse neologismo, dos discursos que lhe são subjacentes e das práticas que autoriza permitiu identificar três vertentes por meio das quais ele comparece na atualidade: como modo de nomear o parent, como modo de dar conta das mudanças no campo da família e sob a forma de um discurso público, veiculado pelo especialista da família. Analisar separadamente cada uma dessas vertentes, ler a consistência que o termo parentalidade vem ganhando na atualidade como o que é "sintomático desta época", e circunscrever a família em sua função de resíduo reduzida às condições mínimas necessárias para que haja sujeito -, foi fundamental para estabelecer as bases para as articulações possíveis entre família, parentalidade e época. O percurso realizado permite afirmar que a família como resíduo, ancorada nas funções materna e paterna e nos modos como pai e mãe se conformam em semblantes, está do lado da estrutura: necessária, mas pendente do que é da ordem da contingência, ou seja, é descompletada pelos traços, posições e valores que prevalecem em determinada época no laço social e pela posição singular dos sujeitos implicados em cada uma dessas funções. A psicanálise, ao bascular entre o universal e o homogêneo que os discursos sobre a parentalidade veiculam e a singularidade inerente à noção de família como resíduo, faz comparecer a impossibilidade de recobrimento da falta (condensada no aforismo lacaniano "não há relação sexual"). De modo que ao PARA TODOS inerente 
aos discursos sobre a parentalidade, à psicanálise cabe responder reenviando cada família à sua singularidade. Contudo, o impasse se produz quando a parentalidade é apresentada como necessariamente aniquiladora da família em sua condição de resíduo, implicando um risco para as crianças, para "os filhos da parentalidade”. O encontro com o livro $O$ dia em que meu pai se calou, de Virginie Linhart principalmente o espanto diante do enunciado "as crianças de 68" -, permitiu que esta investigação se distanciasse de modos genéricos ou universalizantes de compreensão, aos quais o tema pesquisado revelou-se particularmente sensível. Habilitou também um posicionamento diante dos autores que, ancorados nas mudanças no âmbito da família, prenunciam um futuro dramático para o sujeito. Ao longo desta pesquisa, penso ter reunido elementos para questionar a validade de enunciados como "os filhos da parentalidade" e, um dos "achados" em direção ao qual o espanto me precipitou, é que uma época não conforma um "nós" com os sujeitos que dela fazem parte. Ao exceder o "nós" no modo de gozo singular do qual cada pai e cada mãe dão testemunho na transmissão, a família tende a continuar abrindo furos na consistência e na assepsia previstas nos discursos normativos e ortopédicos sobre a parentalidade.

Palavras-chave: psicanálise, família, parentalidade, sujeito, contemporaneidade, educação 


\begin{abstract}
TEPERMAN, D. W. Family, parenting and age: an "us" that does not exist. Thesis

(doctorate). Faculdade de Educação, Universidade de São Paulo, São Paulo, 2012.
\end{abstract}

"Parenting" is a neologism that has been achieving consistency over the last years and that tends to replace the term "family". It is possible to identify this concern in various authors, from different disciplines, extracting different consequences from the possible replacement of the term. Would there actually be such an aspiration in this new term and in its underlying speeches? Would such an aspiration be sustainable when one understands that, at the present times, the family experiences an unprecedented crisis? Would parenting implicate a risk for the familial transmission? Questioning such issues was the starting point from which I initiated this research. The initial unease was provoked by the understanding that the new term would be inseparable from the intervention of the specialist in the sphere of the family and by the mistrust that it would secure its basis in the lack of differentiation and asepsis in the familial transmission. The investigation of the origins of this neologism, of its underlying speeches and of the practices that it authorizes has enabled the identification of three streams through which it appears today: how to nominate the parent, as a means to handle the changes in the sphere of the family and shaped as a public speech conveyed by the family specialist. To evaluate each of these aspects individually, to recognize the consistency that the term parenting continues to achieve in current times as "symptomatic of today's scenario", and to circumscribe the family in its function of residue - reduced to the minimum necessary conditions for existence of subject - was fundamental in order to establish the basis for the possible articulations among family, parenting and age. The roadmap that was accomplished allow us to state that the family as residue, grounded in the motherhood and fatherhood functions and in the manners by which father and mother are shaped as semblants, is side by side with the structure: needed, however dependent on what relates to contingency, that is, it is uncompleted by the features, positions and values that prevail in social speech in the social ties in a certain age, and by the singular position of the subjects implicated in each of these functions. Psychoanalysis, as it tilts between the universal and the homogeneous that are 
driven by the speeches about parenting and the singularity that is inherent to the notion of family as residue, report the impossibility of covering the lack (condensed in the lacanian aphorism "there is no sexual relationship"). In such a way that FOR EVERY ONE inherent to the speeches about parenting, the role of psychoanalysis is to respond by resending each family to its singularity. Nevertheless, a deadlock is generated when parenting is presented necessarily annihilating the family in its condition of residue, implicating in risk for the children, for "the sons of parenting". The encounter with the book The Day in which my father went silent, from Virginie Linhart - mainly the amazement in the face of the consistency of the statement "the children from 68" -, has enabled this investigation to distance from generic or universalized manners of comprehension, to which the researched theme has proved to be particularly sensitive. It has also enabled a positioning in the face of the authors, who, grounded in the sphere of the family, foreshadow a dramatic future for the subject. Throughout this research I believe I have gathered the elements to question the validity of statements such as "the sons of parenting", and one of the "findings" to which direction I was led by the amazement is that an age does not shape an "us" with the subjects that are part of them. As it exceeds the "us" in the singular jouissance from which each father and each mother provide their testimony in the transmission, the family is inclined to continue to generate leaks in the consistency and in the asepsis foreseen in the normative and orthopedic speeches about parenting.

Key words: psychoanalysis, family, parenting, subject, contemporaneousness, education. 


\section{SUMÁRIO}

INTRODUÇÃO.................................................................................................................14

\section{CAPÍTULO 1 - A FAMÍlIA NA PSICANÁLISE DE ORIENTAÇÃO LACANIANA.....19}

1.1 - UMA PRIMEIRA FORMULAÇÃO SOBRE A FAMÍLIA: O LACAN DE 1938 ............................20

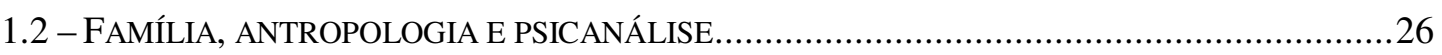

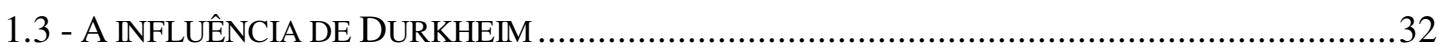

1. 4 - A TESE DO DECLÍNIO DA IMAGO PATERNA E SUAS CONSEQÜÊNCIAS................................37

1.5 - DO PAI DE FAMÍLIA AO PAI COMO RESÍDUO: AS DECLINAÇÕES DO PAI EM LACAN ..........44

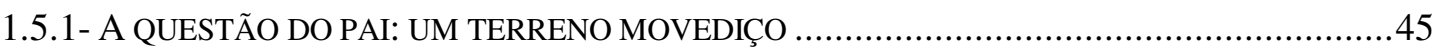

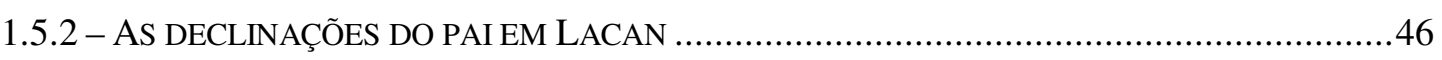

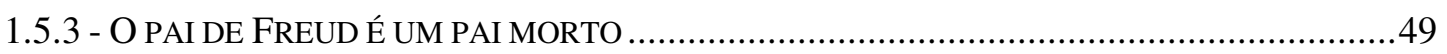

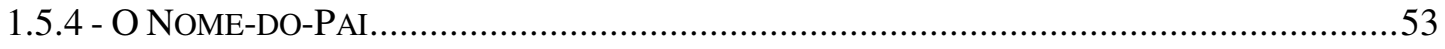

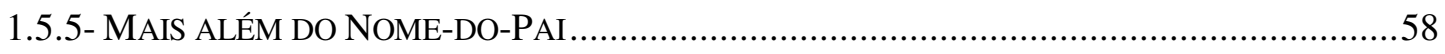

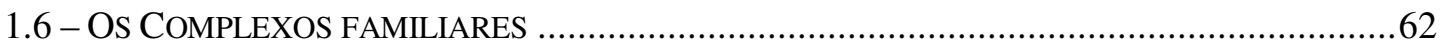

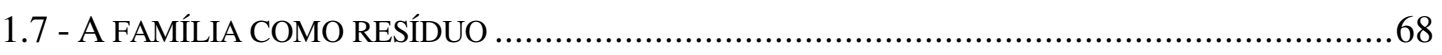

CAPÍTULO 2 - MUDANÇAS NO CONTEXTO HISTÓRICO, MUDANÇAS NA

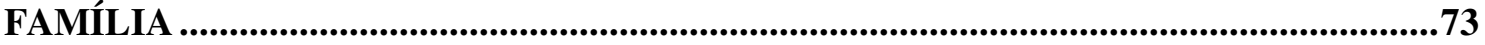

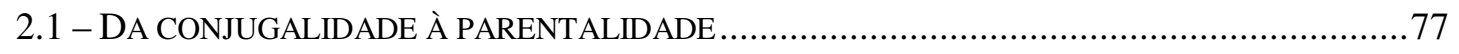

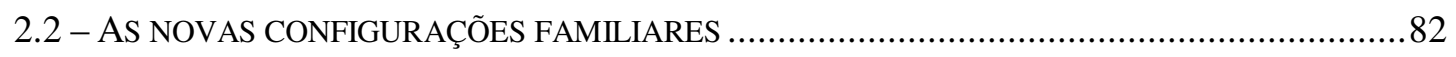

2.3 - ÉPOCA: UM RECORTE ESPECÍFICO NA HISTÓRIA .......................................................91

2. 4 - DO MAL-ESTAR NA CIVILIZAÇÃO AO MAL-ESTAR NA ATUALIDADE ...............................98

\section{CAPÍTULO 3 - PARENTALIDADE: UM NEOLOGISMO QUE GANHA} CONSISTÊNCIA NA ATUALIDADE

3.1 - A PARENTALIDADE COMO UM MEIO DE NOMEAR O PARENT OU AQUELE QUE OCUPA O LUGAR

3.2 - A PARENTALIDADE COMO UM MEIO DE DAR CONTA DAS TRANSFORMAÇÕES NO CAMPO DA FAMÍLIA 
3.3 - A PARENTALIDADE COMO UM DISCURSO DE ORDEM PÚBLICA

3.3.1 - AS ORIGENS DAS POLÍTICAS PÚBLICAS DE APOIO À PARENTALIDADE NA FRANÇA.... 122

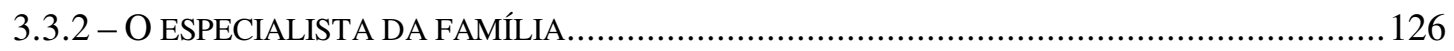

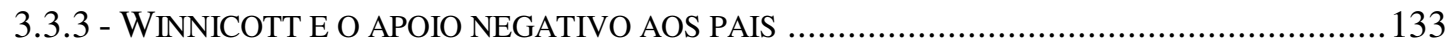

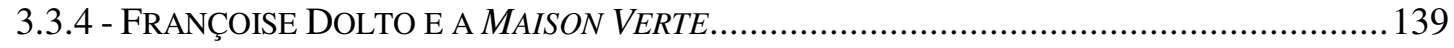

3.4 - A PARENTALIDADE COMO O SINTOMÁTICO DESTA ÉPOCA …......................................147

CAPÍTULO 4 - UM “NÓS” QUE NÃO EXISTE.............................................................156

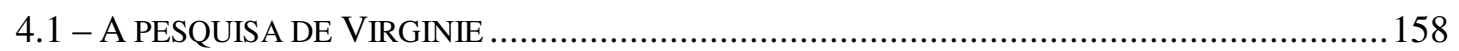

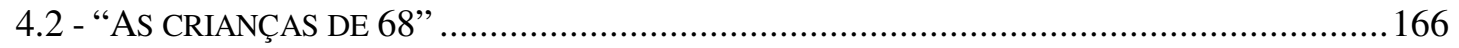

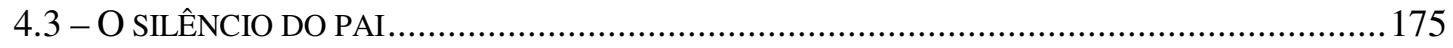

CAPÍTULO 5 - CONSIDERAÇÕES FINAIS: A PARENTALIDADE PARA TODOS,

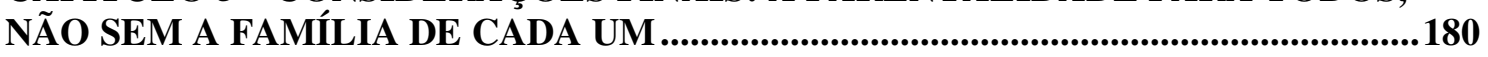

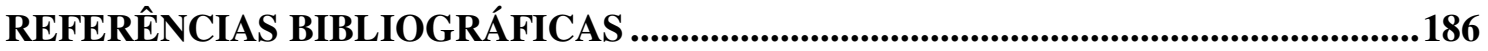




\section{Introdução}

"Parentalidade" é um neologismo que vem ganhando consistência nos últimos anos e que tende a substituir o termo "família”. É possível localizar essa preocupação em diversos autores, de diferentes disciplinas, extraindo da possível substituição diferentes consequências. Haveria mesmo nesse novo termo e nos discursos que lhe são subjacentes essa pretensão? Sustentar-se-ia tal pretensão na leitura de que a família vive uma crise sem precedentes na atualidade? A parentalidade implicaria em um risco para a transmissão familiar? Foi a partir desses interrogantes que iniciei esta pesquisa.

O termo "parentalidade" vem chamando a minha atenção há algum tempo. O incômodo inicial foi provocado pelo entendimento que ele seria indissociável da intervenção do especialista no campo da família (dando corpo a ofertas como as "Escolas para Pais" "), pela imprecisão com a qual era utilizado por psicólogos e psicanalistas e pela desconfiança de que fincaria suas bases na indiferenciação e na assepsia na transmissão familiar.

Eu vislumbrava que o uso crescente do termo "parentalidade" poderia ser revelador do modo pelo qual o mal-estar comparece na atualidade ao se particularizar no campo da família. Mas bem, se apresentaria a parentalidade como uma solução para o mal-estar ou seria ela mesma a causadora deste? Interrogante que me levou ao estudo da família e das novas configurações que esta vem adquirindo na atualidade.

O estudo das publicações dedicadas às novas configurações familiares mostra que esse é um tema extremamente espinhoso, sobretudo porque envolve discussões que tendem à normalização e à indiscriminação entre dados de pesquisa, formulações teóricas e posicionamentos pessoais. Permite também observar que esse tema é particularmente sensível a generalizações, que empobrecem a discussão e autorizam enunciados como

\footnotetext{
${ }^{1}$ Em reportagem de 12 de fevereiro de 2009, o Caderno Equilíbrio da Folha de São Paulo divulgou a abertura na Espanha de uma Universidade de Pais, que pretende "ensinar adultos a educar seus filhos" e cuja proposta é "monitorar os pais desde o último trimestre de gravidez até os 16 anos da criança, por meio de aulas organizadas por especialistas e fundamentadas em princípios da pedagogia e da psicologia".
} 
"esses pais", "essas famílias", "as famílias de hoje”, etc. Assim sendo, uma preocupação que estará na base dessa investigação é a de como abordar tal temática sem recair em enunciados como esses. No capítulo 2, além de realizar um levantamento dos estudos sobre a família na atualidade, procurarei destacar como os psicanalistas se situam diante da demanda, cada vez mais insistente, de marcar uma posição diante das novas formas pelas quais a família tem reivindicado legitimidade.

Ao deter-me na possível tendência de o termo "parentalidade" vir a substituir o termo "família", procurarei isolar a família em sua condição mínima para a transmissão dos elementos necessários para que haja sujeito, o que o leitor encontrará traduzido nos termos de a família como resíduo.

É a particularidade do modo como a psicanálise de orientação lacaniana toma a família como objeto que permite localizar a sua função de resíduo, assim como afirmar que a família resiste, mesmo que se apresente na atualidade por meio de novas configurações. Ao longo do capítulo 1, procurarei circunscrever a família em sua função de resíduo. Com isso, pretendo discriminar a psicanálise dos dispositivos de normalização e separála das disciplinas que preconizam que determinada forma de família é mais adequada para a educação das crianças. Ressaltarei também que não existe uma forma de organização familiar ideal que possa garantir as condições necessárias para a constituição do sujeito e que o modelo de família nuclear nunca foi sinônimo de "normalidade".

O percurso realizado ao circunscrever a família em sua função de resíduo visará esvaziar a perspectiva de que existiria um bom modo de ser pai ou de ser mãe, e, mais que isso, destacar que a diferença sexual, assim como as "faltas" ou imperfeições, são imprescindíveis na transmissão familiar. Contudo, a parentalidade parece comportar um ideal: apresenta-se investida por pais competentes, implicados em um modo de vida voltado à educação das crianças e despojado dos dramas inerentes à família. $\mathrm{O}$ especialista, ao oferecer-se como indispensável e dispor de pautas para o exercício das funções parentais, incute nos pais na idéia de que existe um modo, um bom modo, de TODOS eles se converterem em bons pais. Será que a crescente consistência que o neologismo "parentalidade" vem adquirindo na atualidade poderá perturbar a 
transmissão familiar? Será que a família, ao assumir-se como uma "parentalidade", finalmente se verá livre dos excessos e das faltas inerentes à transmissão familiar?

Diante desse cenário, dedicarei alguns parágrafos a dois psicanalistas que sempre me serviram de norte no que tange à interferência do especialista no campo da família. Winnicott já defendia um "apoio negativo aos pais" na década de 60, posicionando-se vigorosamente contra a interferência no campo da família. Tendo se disposto a se dirigir aos pais em programas de rádio e em seus escritos, o psicanalista esteve sempre atento aos perigos implicados nesse tipo de transmissão. Françoise Dolto também participou de programas de rádio, e também se mostrava advertida em relação aos riscos de dirigirse ao grande público, atividade que a levou a receber inúmeras críticas de seus pares. Mas Dolto comparece nessa pesquisa mais especificamente pela criação da Maison Verte, instituição de acolhimento a pais e bebês ou crianças pequenas, sustentada na psicanálise e contemporânea ao incremento das políticas de apoio à parentalidade na França. Tendo se recusado a participar das avaliações promovidas pelas agências financiadoras e a submeter-se ao controle pelo poder público, a Maison Verte distanciou-se do "para todos igual" inevitável em qualquer política pública e, ao mesmo tempo, permaneceu fiel a seu projeto inicial, mantendo o lugar para a criança como sujeito do desejo e para a invenção na intervenção sustentada no discurso psicanalítico.

Ao atualizar o posicionamento de Winnicott e de Dolto em relação à intervenção do especialista no campo da família e aos discursos normativos e ortopédicos que este muitas vezes veicula, espero esclarecer que, apesar da demanda dos pais por certezas na educação de seus filhos, demanda que reconheço como legítima, cabe questionar o modo como o psicanalista se posiciona diante dessa demanda. (Vale marcar que muitas vezes é o próprio especialista que gera, ou incrementa tal demanda, a partir das ofertas que institui atribuindo-lhes o caráter de indispensáveis para o bom desempenho das competências parentais). Faço referência especificamente ao psicanalista porque ele não se confunde - pelo menos não necessariamente - com a figura do especialista, e porque "a criança encontra na psicanálise um meio eficaz para lutar contra os efeitos nefastos do discurso que domina o campo social contemporâneo, esse misto de capitalismo e de ciência [...]" (SAURET, 1998, p. 44). Se o psicanalista não escolhe o lugar em que se impõe o pedido social - lugar em que é demandado - pode sim escolher a sua resposta. 
Em relação a esse ponto, Sauret (1998) lembra duas observações de Lacan. A primeira é um convite a examinar as instituições que recebem crianças, de modo a localizar a forma pela qual o campo social entende tratar o sujeito.

A segunda é uma denúncia dos próprios psicanalistas por, não apenas não terem sabido impor a concepção do sujeito que decorre da descoberta freudiana, mas ainda por se terem feito os cúmplices de uma psicologização, e até mesmo de uma mitologização dos indivíduos, que entrega estes últimos de mãos e pés atados ao tratamento a que o campo social entende submetê-los (p. 61).

Ao situar a família como resíduo do lado da estrutura e ao ler a parentalidade como um fenômeno atual - ou como o sintomático desta época conforme proporei no capítulo 3 do lado da história torna-se imprescindível formular as articulações possíveis entre estrutura e história. Procurarei investir nessa articulação de forma cuidadosa, mas não exaustiva, valendo-me do modo a que Lacan sempre esteve atento, na tentativa de isolar o que é da ordem da estrutura, para também inscrever ali a história do sujeito, submetendo a primeira à prova com a vivacidade da clínica. Para realizar essa tarefa recorrerei a outros autores que retomam o texto de Lacan e lhe acrescentam novos alinhavos.

Tomando a recomendação de Lacan de que o psicanalista deve estar à altura de sua época, movida pelo mal-estar diante da insistência do termo parentalidade nos diversos discursos sobre a criança e sobre a família, senti-me convocada a localizar o contexto e as circunstâncias nas quais esse termo vem encontrando um terreno fértil. No capítulo 3 o leitor encontrará uma investigação sobre as origens do termo parentalidade e sobre cada uma das três vertentes por meio das quais esse neologismo comparece na atualidade: como modo de nomear o parent, em um discurso psicológico/psicanalítico; como modo de dar conta das mudanças no campo da família, sejam elas produzidas pelas mudanças nos costumes (famílias monoparentais, homoparentais, pluriparentais) e/ou pela procriação medicamente assistida, em um discurso social/jurídico, e sob a forma de um discurso público, veiculado pelo especialista da família, ou pelo "especialista da subjetividade", conforme o estudo realizado por Volpe (2011). É 
importante destacar que essas vertentes e os discursos que ensejam se influenciam mutuamente.

Para avançar nessa pesquisa e me separar das confusões e imprecisões que identifico em muitos estudos sobre o termo parentalidade, tratarei separadamente cada uma dessas vertentes. Acredito que tal discriminação faz falta nas leituras realizadas por alguns dos autores que se ocupam desse tema. Ao longo da pesquisa, tratarei mais detidamente da parentalidade como um modo de reconhecer e legitimar as novas formas de família no campo jurídico e da parentalidade como um discurso público, que traduzo como um discurso normativo e ortopédico. Nas referências à parentalidade como um modo de sutura da falta prevalente na atualidade, ou seja, como o que é sintomático nesta época, avalio que esta discriminação não será necessária.

Iniciei esta pesquisa mobilizada pelo mal-estar que me causava a consistência crescente dos discursos sobre a parentalidade no campo social, mais especificamente no terreno da educação e da psicologia. A investigação das articulações possíveis entre família e parentalidade mostra que o impasse se produz quando a parentalidade é apresentada como necessariamente aniquiladora da família em sua condição de resíduo, implicando um risco para as crianças, para "os filhos da parentalidade". O encontro com o livro O dia em que meu pai se calou, de Virginie Linhart (descrito no capítulo 4), e o espanto diante da consistência do enunciado "as crianças de 68" abrem brechas para evitar o risco de recair em modos genéricos ou universalizantes de compreensão aos quais esse tema é particularmente sensível. Permite também evitar a possível identificação com os autores que, ancorados nas mudanças no campo da família, prenunciam um futuro dramático para o sujeito. 


\section{Capítulo 1 - A família na psicanálise de orientação lacaniana}

"o sujeito é unicamente responsável pelo que ele faz de seus determinantes" (SAURET, 1998, p. 30)

A família é reconhecidamente objeto de estudo da sociologia, da antropologia e, cada vez mais, do campo jurídico, devido à demanda pela regulamentação e pelo reconhecimento das novas e variadas configurações familiares que têm se apresentado na atualidade. Neste capítulo, examinarei o particular recorte que a psicanálise de orientação lacaniana realiza ao debruçar-se sobre a família, e, para estabelecer o que é uma família na orientação lacaniana será preciso retornar a um texto precursor de Lacan, traduzido inicialmente como A família e depois como Os Complexos Familiares na formação do indivíduo. Veremos que o pensamento de Durkheim influenciou Lacan naquele tempo - o texto data de 1938 - e procurarei destacar o que há nele de extremamente atual, malgrado as críticas de familiarista rendidas a seu autor. Esse texto também deu margem - ao confundir o pai de família com a função paterna - à exaustiva discussão em torno do declínio da imago paterna, que ainda persiste e é referida ao ensino de Lacan, apesar do distanciamento do psicanalista, ao longo do seu ensino, dessa perspectiva inicial. Tal temática foi retomada por Lacan a partir de 1953 quando se dedicou a explorar o "movediço" para o qual a questão do pai pareceu arrastar os psicanalistas.

Ao debruçar-se sobre a família, a psicanálise de orientação lacaniana procura isolar sua condição de resíduo, ou seja, a condição mínima para a transmissão dos elementos necessários para que haja sujeito. Trata-se da família reduzida ao que é irredutível na transmissão. É com ela que a psicanálise de orientação lacaniana opera e que, veremos ao longo deste trabalho, habilita um posicionamento diante da consistência que os discursos sobre a parentalidade vêm ganhando na atualidade. 


\section{1 - Uma primeira formulação sobre a família: o Lacan de 1938}

Diversos autores, entre eles Miller (2007, 1984), Peusner (2009) e Roudinesco (2003), situam o texto de Lacan intitulado Os complexos familiares na formação do indivíduo, publicado em 1938, como particularmente especial, devido ao modo pelo qual este responde ao convite para compor a seção sobre "Família" no tomo VIII da Encyclopédie Française (publicada pelo Editorial Larousse, consagrado à "Vida mental"), e pelo que Lacan já alcança formular, mesmo em um tempo inicial de sua produção escrita. Ademais, essa publicação é tomada como precursora no ensino de Lacan e não oferece obstáculo ao que virá depois (Miller, 1984).

O texto recebeu inicialmente um título "falso": A família. Miller (1984) pontua que não é possível compreendê-lo se nos pautarmos por este título, lembrando que o texto fazia parte da Encyclopédie Française, cujas principais linhas foram traçadas pelo psicólogo Henri Wallon:

Graças lhe sejam dadas por ter recorrido a Lacan - que, na época, não era bem uma persona grata - para escrever um capítulo. Foi Wallon que organizou os capítulos: "A família", "A escola", "A profissão". É abusivo considerar que era com a família que Lacan se ocupava. $\mathrm{O}$ verdadeiro título do texto é completamente diferente: Os complexos familiares na formação do indivíduo (MILLER,1984, p. 2).

O estudo de Os complexos familiares na formação do indivíduo é central para o estabelecimento dos fundamentos dessa pesquisa ao permitir destacar e organizar o que é particular à psicanálise de orientação lacaniana no que diz respeito à família, distinguindo-a das outras disciplinas que se debruçam sobre esse campo de investigação, ainda que conte com as importantes contribuições que advêm daquelas (mais especificamente da sociologia, da antropologia e do direito, como veremos ao longo deste trabalho).

Lacan interessa-se pela família tomando-a como "objeto e circunstância psíquica" (1938, p. 19), descarta toda e qualquer possibilidade de restringi-la a um fenômeno biológico e introduz a noção de complexo em oposição à noção de instinto. Inicia $O s$ complexos familiares situando a família como "um grupo natural de indivíduos" unidos por uma dupla relação biológica, a geração e o ambiente, este último constituído por 
"adultos geradores que asseguram sua função". Já nas primeiras linhas é possível destacar a especificidade por meio da qual a família se institui como um objeto de estudo para a psicanálise, quando se volta para a família, interessa-lhe destacar o lugar dos "adultos geradores que asseguram sua função". Esse ponto é evidenciado em um escrito posterior, de 1969, tão diminuto quanto importante na obra de Lacan, Nota sobre a criança, no qual circunscreve a função de resíduo sustentada pela família conjugal, responsável por uma transmissão irredutível, assegurada pelo exercício das funções materna e paterna. Retornarei a esse escrito mais adiante.

Lacan destaca ainda que as relações que se estabelecem entre "geração" e "geradores" não interessam à psicanálise por seu caráter biológico, mas sim pelo que se apresenta como "continuidade psíquica"; sua intenção na época é organizar o campo da família, de modo a afastar a concepção psicanalítica da família definitivamente do acontecimento biológico. Posteriormente, na Nota sobre a criança, Lacan é enfático ao conduzir o leitor a não confundir as funções parentais com a satisfação das necessidades.

No texto de 1938, já é possível antever que a função que Lacan atribui aos adultos geradores não tem um caráter biológico, mas social, cultural. Nesse sentido, Peusner (2009) e Miller (1984) destacam o termo "economia paradoxal dos instintos". O "paradoxal" introduzido neste contexto visa a afastar toda e qualquer determinação biológica; o termo "comportamentos adaptativos de variedade infinita" também habilita a mesma leitura, assim como a afirmação de que "as instâncias culturais dominam as naturais". Com isso, já no segundo parágrafo do referido escrito, Lacan situa a especificidade da espécie humana.

Miller (2007) acrescenta o seguinte comentário acerca do termo "economia paradoxal dos instintos": "Os instintos são, na espécie humana, tributários das modificações paradoxais das necessidades" (p. 4). No seu comentário sobre Os Complexos Familiares, Miller (1984) destaca o modo como Lacan extrai o funcionamento instintivo da condição do ser falante, centrando-se nos complexos, formas dominadas pelos fatores culturais, traduzindo da seguinte forma o domínio das instâncias culturais sobre as naturais: "O que é uma maneira de dizer que, no homem, a língua, por meio do 
significante, domina tudo aquilo que é natural e que é o que se passa na família humana" (MILLER, 2007, p. 4).

Nesse ponto, não posso deixar de me deter para comentar uma publicação absolutamente particular, inteligente e irônica, ela resvala o tempo todo na radicalidade daquilo que nos separa do mundo instintivo dos animais, pelo modo como, ao falar e suportar o mal-entendido que este ato implica, uma perda irreparável se consuma. Tratase do livro em quadrinhos $O$ gato do rabino, de Joann Sfar. Ainda que o livro, como o título indica, se concentre no judaísmo - o gato do rabino quer fazer Bar-Mitzvah e persegue o rabino com insistentes indagações e questionamentos que justificam esta demanda -, toca naquilo que nos arranca da determinação biológica: o gato do rabino engole o papagaio da família e começa a falar. Mas o gato do rabino não se contenta em repetir algumas palavras tolamente, como fazia o papagaio, ele começa a falar. E, ao falar, torna-se tão humano que inclusive sonha: "desde que passei a falar, tudo mudou, tenho pesadelos" (SFAR, 2006, p.31). E em suas aventuras junto ao bicho homem, passa a sentir compaixão:

Desde que passei a falar, virei um bicho esquisito. Eis que sinto simpatia por esse humano que me desfere pontapés. Enquanto o achava intransigente e virtuoso, eu o odiava. A partir do momento em que sei que tem duas caras e é hipócrita, que o vejo se debater entre seus hormônios e suas convicções, amo-o (SFAR, 2006, p. 48).

A experiência do gato do rabino leva o leitor a deparar-se com a desnaturação da natureza: para falar, o homem paga com a necessidade de se separar; ao ganhar a linguagem, perde a certeza diante da palavra.

A condição humana, ou seja, o que o falar implica, afasta-nos definitivamente de qualquer determinação instintiva ou biológica: "Logo, são a perda, o vazio que especificam a condição humana. Em holandês, o título da obra de André Malraux, "A condição humana" foi traduzido por Het menselijke, a "falta humana". Não se podia dizer melhor!" (LEBRUN, 2008, p. 68).

Voltando ao comentário sobre os Complexos Familiares, penso que é notável como em apenas duas páginas o autor localiza a especificidade da psicanálise diante do que se denomina família. Agrupo-a a seguir em dois pontos centrais: 
- um fenômeno social, cultural, uma instituição não redutível ao fato biológico, na qual as instâncias culturais dominam e prevalecem sobre as naturais.

- uma estrutura hierárquica, que prevalece na primeira educação, na repressão dos instintos, na aquisição da língua materna, desempenhando um papel fundamental na transmissão da cultura.

Lacan destaca em seu escrito de 1938 o caráter singular das relações sociais preconizadas pela espécie humana. Nesse ponto, recorro ao Freud de O Mal-estar da civilização, texto de 1929, no qual o autor não só frisa o caráter singular das relações sociais, mas se concentra no mal-estar que elas implicam. Freud (1929) situa três modos pelos quais o sofrimento nos ameaça: a partir do próprio corpo, condenado à decadência e ao aniquilamento; a partir do mundo exterior, capaz de atentar contra nós com forças destrutíveis, onipotentes e implacáveis; e a partir das relações com outros seres humanos, nas quais constata “[...] a insuficiência de nossos métodos para regular as relações humanas na família, no Estado e na sociedade" (p. 3031). O autor define esta última fonte de sofrimento como a mais dolorosa para a humanidade!

Diante da dor que nos provocam as relações sociais, Freud formula uma pergunta crucial: por que as instituições que nós mesmos criamos não representam proteção e bem-estar para todos? Ao se dedicar a respondê-la podemos antever que o psicanalista começa já a suspeitar de que, se vamos tão mal no que diz respeito à prevenção do sofrimento, deve ser porque essa estaria referida a uma porção indomável da natureza, da natureza de nossa própria constituição psíquica.

No texto citado, Freud apresenta a seguinte definição de cultura: “[...] a soma das produções e instituições que distanciam nossa vida da de nossos antecessores animais e que servem a dois fins: proteger o homem contra a Natureza e regular as relações dos homens entre si” (FREUD, 1929, p. 3033, tradução livre).

Um traço característico de uma cultura seria a forma pela qual são reguladas as relações entre os homens, ou seja, as relações sociais que o indivíduo estabelece como membro de uma família ou de um Estado. Na base dessa "regulação" estabelecida pela cultura assenta a substituição do poder individual pelo da comunidade, de modo que seus 
membros restringem suas possibilidades de satisfação, enquanto que o indivíduo não reconhecia semelhantes restrições (FREUD, 1929).

Vejamos agora a definição de cultura que pode ser extraída do escrito de 1938 de Lacan: "Comportamentos adaptativos de variedade infinita são assim permitidos. Sua conservação e seu progresso, por dependerem de sua comunicação, são, antes de tudo, obra coletiva e constituem a cultura" (p. 11). Cultura, então, pode ser definida como a obra coletiva de conservação e progresso dos comportamentos adaptativos da espécie humana, pela via do simbólico, ainda que no texto Lacan utilize o termo "comunicação".

Em relação a esse pequeno trecho observo que, ao falar em 'variedade infinita', Lacan aponta para o fato de que, nas relações familiares, há lugar para a invenção; parece, portanto, abrir a possibilidade - será que inadvertidamente? - de reconhecer uma família independentemente das diferentes configurações com as quais ela possa se apresentar.

No decorrer desse escrito, conforme marcado anteriormente, Lacan dedica-se a fundamentar os pontos a partir dos quais a psicanálise se diferencia no que diz respeito à investigação em torno da família (um fenômeno cultural e não biológico):

As formas primitivas da família têm os traços essenciais de suas formas acabadas: autoridade, se não concentrada no tipo patriarcal, ao menos representada por um conselho, por um matriarcado ou seus delegados do sexo masculino; modo de parentesco, herança, sucessão, transmitidos, às vezes distintamente (Rivers), segundo uma linhagem paterna ou materna. Trata-se aí de famílias humanas devidamente constituídas. Mas, longe de nos mostrarem a pretensa célula social, veem-se nessas famílias, quanto mais primitivas são, não apenas um agregado mais amplo de casais biológicos, mas sobretudo um parentesco menos conforme aos laços naturais de consangüinidade (LACAN, 1938, p. 14).

Na sequência, Lacan observa que a família primitiva desconhece os laços biológicos de parentesco e que, em muitas culturas, o parentesco só é reconhecido por meio de ritos que legitimam os laços de sangue, criando até mesmo laços fictícios. Mesmo nos sistemas mais primitivos de agrupamento familiar, o sistema simbólico cria os vínculos familiares; dessa maneira, o vínculo familiar é simbólico por excelência. 
No direito romano, a paternidade natural não tem significação, a filiação biológica não é considerada se não for seguida pela palavra. Assim, o pai pode legitimar um filho natural, mas também pode instituir como herdeiro um estranho:

O pai não é, portanto, um pai procriador senão na medida em que é um pai pela fala. E esse lugar atribuído ao verbo tem como efeito ao mesmo tempo reunir e cindir as duas funções da paternidade (pater e genitor), a da nomeação e a da transmissão do sangue ou da raça (ROUDINESCO, 2003, p. 23).

Um aspecto interessante é que, em 1938, Lacan define a família moderna como um grupo reduzido, mas nem por isso mais simplificado; ao contrário, trata-se de uma “contração da instituição familiar" que apresenta uma estrutura profundamente complexa. Conclui o primeiro capítulo apontando para o remanejamento profundo que conduziu a instituição familiar à sua forma atual, e o atribui ao casamento. Neste ponto reitera a posição adotada por Durkheim de distinguir "casamento" de "família", daí a decisão de adotar o termo "família conjugal". Esse parágrafo se apresenta, no final das contas, de forma extremamente condensada, deixa entrever a influência do pensamento durkheimiano nas formulações de Lacan, mas não permite calcular sua dimensão. Mais adiante, examinarei cuidadosamente a aula ministrada por Durkheim acerca da família conjugal com o intuito de situar mais claramente essa influência.

O valor desse escrito precursor de Lacan é acentuado por Miller (1984) da seguinte maneira:

Tal como é praticado nos dias de hoje, o desmame poderia parecer mais próximo das exigências da natureza. Justamente aqui, as referências à antropologia e à história vêm, como peça de apoio, justificar, testemunhar que, na espécie humana, fez-se todo tipo de coisa com o desmame, que não se encontra nele uma fixidez comparável à do instinto e que, pelo contrário, é preciso dizer claramente que se inventaram diversas formas de desmame. Podemos ver para que servem essas referências à antropologia e à história. Aqui, servem sempre para demonstrar que não há relação com esse objeto, no sentido em que Lacan dirá mais tarde: 'não há relação sexual $^{2}$. Isso significa que não está escrito no instinto e, desde então,

\footnotetext{
${ }^{2}$ A noção de relação sinaliza um ajuste perfeito. O aforismo "não há relação sexual" aponta justamente para a impossibilidade de conjugar sem resto. Penso que essa formulação aparentemente enigmática e provocativa - como costumam ser as formulações de Lacan - pode e deve ser tratada sem rodeios uma vez que se declina como estrutural, e por isso, incontornável, "[...] já que uma relação sexual faz falta em todas as formas de sociedade" (LACAN, 1974, p. 13).
} 
há lugar para a invenção humana, para a invenção do mundo

simbólico, precisamente porque nesse lugar nada está escrito (p.10).

Lacan, em seu escrito de 1938, detalha o segundo ponto que destaquei anteriormente - a família como uma estrutura hierárquica, que prevalece na primeira educação, na repressão dos instintos, na aquisição da língua materna, desempenhando um papel fundamental na transmissão da cultura - marcando que outros grupos sociais se ocupam de aspectos como as tradições espirituais, a manutenção dos ritos e dos costumes, a conservação das técnicas e do patrimônio, mas “[...] a família prevalece na primeira educação, na repressão dos instintos, na aquisição da língua acertadamente chamada materna" (LACAN, 1938, p.13); acrescenta ainda que "a família preside os processos fundamentais do desenvolvimento psíquico", ultrapassando, dessa forma, em sua transmissão, os limites da consciência.

Continuando no texto de 1938, encontramos a seguinte definição de família: “[...] órgão privilegiado desta coação do adulto sobre a criança, coação à qual o homem deve uma etapa original e as bases arcaicas de sua formação moral" (p. 12). Lacan toca no ponto em que a família atualiza em seu núcleo uma função cultural, uma função civilizatória, mas ao mesmo tempo abre uma brecha para o entendimento de que o modo como cada família o faz e o modo pelo qual essa transmissão se atualiza em cada sujeito é absolutamente singular. Esses aspectos tornam-se mais evidentes quando o autor introduz a noção de constelação familiar e podem ser reconhecidos como eixos centrais para o que, mais adiante, será formulado em termos da família como resíduo.

\section{2 - Família, antropologia e psicanálise}

Destacar a família em sua função de resíduo, ou seja, em sua condição mínima necessária para que haja sujeito implica arrancá-la do contexto das determinações biológicas, mas não fazer o mesmo com suas determinações culturais. Se Durkheim influenciou o Lacan de 1938, a partir de 1953 a antropologia de Lévi-Strauss, mais particularmente seu estudo sobre as estruturas elementares de parentesco, inspirou fortemente sua produção. Para Lacan, a psicanálise só teria a se beneficiar ao estabelecer uma equivalência com os termos da antropologia, sobretudo no que tange ao incesto e à aliança e a troca (LACAN, 1953c). Os encontros da psicanálise lacaniana 
com a antropologia de Lévi-Strauss foram centrais para alicerçar a família em sua condição de estrutura.

Roudinesco (2003) inicia o livro A família em desordem destacando a universalidade da família (entendida como o laço que se organiza a partir de um nascimento ou de uma criança). Para tanto, recorre a Lévi-Strauss, que, em 1956, assinalou apresentar-se a vida familiar em praticamente todas as sociedades humanas (mesmo aquelas que possuem hábitos sexuais e educativos diferentes dos nossos). Ao repousar sobre a união mais ou menos duradoura e socialmente aprovada entre um homem, uma mulher e seus filhos, a família se institui como um fenômeno universal.

Até então, os antropólogos acreditavam que a família surgira recentemente, após longa e lenta evolução. Contudo, não se conhece praticamente nenhuma sociedade na história do gênero humano em que a família nuclear não tenha desempenhado papel importante, na imensa maioria dos casos, como grupo residente no mesmo domicílio.

Para estabelecer as propriedades invariantes que serviriam para descrever todas as famílias, Lévi-Strauss investigou arranjos familiares em diferentes sociedades e estabeleceu três pontos: a família tem origem no casamento; inclui o marido, a mulher e os filhos nascidos desta união, formando um núcleo ao qual outros parentes podem agregar-se; seus membros estão unidos entre si por laços jurídicos, por direitos e obrigações de natureza econômica, religiosa, por uma rede precisa de direitos e proibições sexuais e por um conjunto variável e diversificado de sentimentos (MANDELBAUN, 2008).

Segundo o antropólogo, a universalidade da família repousa na concepção naturalista da diferença dos sexos, o que não coincide com afirmar que a família consiste em um fenômeno biológico. Para a sua criação são necessárias outras duas famílias que forneçam um homem e uma mulher, sendo necessárias, para sua constituição, a aliança (casamento) e a filiação. A proibição do incesto rege a aliança e se estabelece como lei primordial que superpõe a cultura à natureza.

Diante da pergunta: “onde acaba a natureza e onde começa a cultura?", Lévi-Strauss (2008) observa que há vários meios de responder, mas todos se mostraram 
decepcionantes. Entre eles meios, situa a justificativa de que a proibição do incesto estaria associada a uma medida de proteção, visando defender a espécie dos resultados nefastos dos casamentos consangüíneos. Mas essa justificativa é de origem recente, não aparecendo antes do século XVI, ou seja, a proibição do incesto não teria se instituído a partir de sanções naturais.

A exogamia afirma a existência social de outrem, e só proíbe o casamento endógamo para introduzir e prescrever o casamento com um grupo diferente da família biológica. Certamente não é porque algum perigo biológico se ligue ao casamento consangüíneo, mas porque do casamento exógamo resulta um benefício social ${ }^{3}$. (LÉVISTRAUSS, 2008, p. 521).

Assim sendo, a proibição do incesto não é nem puramente de origem cultural nem puramente de origem natural; constitui o passo fundamental graças ao qual, pelo qual, mas, sobretudo, no qual se realiza a passagem da natureza à cultura. A proibição do incesto não se exprime sempre em função das regras de parentesco real, mas tem por objeto os indivíduos que se dirigem uns aos outros empregando certos termos.

E aqui entramos em um terreno importante: o que define o parentesco para LéviStrauss?

Entendemos por estruturas elementares do parentesco os sistemas nos quais a nomenclatura permite determinar imediatamente o círculo dos parentes e dos aliados, isto é, os sistemas que prescrevem o casamento com um certo tipo de parente. Ou, se preferirmos, os sistemas que, embora definindo todos os membros do grupo como parentes, dividem-nos em duas categorias, a dos cônjuges possíveis e a dos cônjuges proibidos (2008, p. 19).

O parentesco é determinante para a organização da unidade familiar num sistema e para o modo como este se organiza. Vale marcar que no centro das estruturas de parentesco está o nome, e que Lacan identifica nas denominações de parentesco, implicando as regras de aliança e filiação, a possibilidade do reconhecimento das diferenças de sexo e

\footnotetext{
3 "Para os Chukchee, uma 'má família' define-se como uma família isolada 'sem irmão e sem primo"” (BOGORAS apud LÉVI-STRAUSS, 2008, p. 526) Lévi-Strauss recorre a esse exemplo para comentar as respostas às perguntas que Margaret Mead fez aos Arapeshes sobre eventuais infrações às proibições do casamento: 'mas como, casar-te com a tua irmã, não queres um cunhado?'. Com isso o autor localizou as bases para afirmar que o incesto é socialmente absurdo antes de ser moralmente culpável. "A exclamação incrédula arrancada ao informante: Mas então não queres ter cunhado? fornece a regra de ouro do estado da sociedade" (LÉVI-STRAUSS, 2008, p. 526).
} 
de geração (1953c, p. 279). O conceito de parentesco se estabelece, portanto, como um fenômeno de ordem cultural, não determinado pela biologia.

Cada relação familiar define um certo conjunto de direitos e de deveres, e a ausência de relação familiar não define nada. Define a hostilidade. Direitos, privilégios, obrigações, tudo é determinado pelo parentesco. Um indivíduo qualquer deve ser ou um parente real ou fíctício ou então é um estranho, com o qual não se está ligado por nenhuma obrigação recíproca e que se trata como um virtual inimigo (LÉVI-STRAUSS, 2008).

É sempre um sistema de troca que está na origem das regras do casamento. A regra da exogamia tende a garantir, pela proibição do casamento nos graus interditos, a circulação total e contínua das mulheres e suas filhas. A proibição do incesto, dessa forma, é a regra do dom por excelência. A exogamia faz com que o grupo biológico não esteja só, o vínculo de aliança com uma família diferente assegura o domínio do social sobre o biológico, do cultural sobre o natural.

A proibição do incesto e a exogamia têm a função de estabelecer, entre os homens, um vínculo sem o qual não poderiam se elevar acima da organização biológica para atingir a organização social, viabilizando a comunicação com o outro e a integração do grupo. Assim sendo, é o casamento que dá origem a uma família, mas o casamento não é um assunto privado, pois une grupos e famílias; e constitui-se em uma instituição social que garante aos grupos familiares não se fecharem sobre si.

Lacan, no trecho a seguir, toma de empréstimo as formulações da antropologia e, em seu retorno a Freud $^{4}$, precisa a essência da troca que estaria na base das relações humanas:

É essencialmente na ligação sexual, com efeito, e ordenando-a pela lei das alianças preferenciais e das relações proibidas que se apoia a primeira combinatória das trocas de mulheres entre as linhagens nominais, para desenvolver, numa troca de bens gratuitos e numa troca de palavras-chaves, o comércio fundamental e o discurso

\footnotetext{
${ }^{4}$ Reproduzo a seguir o modo como Lacan traduz seu retorno a Freud, antecipando ao leitor que retomarei esse tema mais adiante: "O sentido de um retorno a Freud é um retorno ao sentido de Freud. E o sentido do que Freud disse pode ser comunicado a qualquer um, porque, mesmo dirigido a todos, cada um estará interessado - e basta uma palavra para fazer senti-lo: a descoberta de Freud questiona a verdade, e não há ninguém que não seja pessoalmente afetado pela verdade” (LACAN, 1955, p. 406).
} 
concreto que sustentam as sociedades humanas (LACAN, 1998, p. 433).

As idéias de Lévi-Strauss e de Freud a respeito da proibição do incesto não são incompatíveis, mas estabelecem diferentes focos. Enquanto o primeiro estabelece o valor funcional dessa proibição para a preservação e perpetuação dos grupos sociais, o segundo acentua o valor central da proibição do incesto para a constituição psíquica dos homens.

O antropólogo e o psicanalista também atribuem a origem do casamento a necessidades humanas de diferentes ordens: enquanto o primeiro situa a origem do casamento em necessidades de ordem econômica, ligadas à divisão do trabalho entre os sexos, o segundo a situa (em Totem e Tabu) no reconhecimento, por parte do homem, de suas necessidades sexuais e afetivas contínuas e, por parte da mulher, de sua necessidade de proteção para poder manter junto de si a sua cria (MANDELBAUN, 2008).

Em $O$ mal-estar na civilização, encontramos mais elementos sobre as hipóteses de Freud acerca do que levou o homem a constituir família: sua constituição está vinculada a certa evolução sofrida pela necessidade de satisfação genital, fazendo da mulher uma figura presente e não mais uma "inquilina", que se viu obrigada a permanecer, em interesse da prole, junto ao macho mais forte. De tal maneira, diz Freud, que Eros e Ananké (amor e necessidade) se converteram nos pais da cultura humana. E conclui: não é fácil compreender como esta cultura poderia deixar de fazer felizes os seus membros. Mais adiante, retomarei este mal-estar que, inicialmente, pareceu a Freud descabido e paradoxal.

Se a psicanálise e a antropologia, ao deter-se sobre o mesmo objeto - a família recortam-no a partir de perspectivas diferentes, ao mesmo tempo é possível localizar um parentesco entre elas na posição análoga que assumem em relação ao saber moderno, quando encontramos na antropologia o combate ao etnocentrismo e na psicanálise combate à psicologia da consciência (KOLTAI, 2010).

É cara a Lacan a atribuição por Lévi-Strauss de uma função simbólica à proibição do incesto, pois permite desbiologizar o complexo de Édipo, atribuindo-lhe uma função 
simbólica. Lévi- Strauss e Lacan encontram-se ao atribuir uma universalidade à função simbólica, mas não a seu conteúdo.

Lacan destaca que nem sempre as estruturas do parentesco são elementares, pontuando que as nossas são bastante complexas, mas não existiriam sem o sistema de palavras que as organizam

[...] e o fato é que os interditos que regulam em nós a troca humana das alianças, no sentido próprio da palavra, limitam-se a um número excessivamente restrito. Por conseguinte, tendemos a confundir termos como pai, mãe, filho, etc. com relações reais. É porque o sistema das relações de parentesco reduziu-se extremamente, em seu limite e em seu campo. Mas trata-se de símbolos (1953a, p. 32).

Em Função e campo da fala e da linguagem, Lacan retoma as estruturas elementares de parentesco explicitadas em termos das regras de aliança e troca, aplicando-lhes as leis da linguagem. Localiza nestas regras a dimensão inconsciente que, acredita, estaria na base das estruturas elementares. Observa que as regras da aliança ordenam o sentido em que é realizada a troca das mulheres e que ocorre em uma infinidade de formas; "a aliança rege uma ordem preferencial cuja lei, implicando os nomes de parentesco, é para o grupo, como a linguagem, imperativa em suas formas, mas inconsciente em sua estrutura" (1953c, p. 278). Nesse sentido, o Édipo marca a lógica subjetiva que se instala a partir da estrutura de parentesco como

[...] aquilo que o sujeito pode conhecer de sua participação inconsciente no movimento das estruturas complexas das alianças, verificando os efeitos simbólicos, em sua existência particular, do movimento tangencial para o incesto que se manifesta desde o advento de uma comunidade universal (1953c, p. 278).

É possível extrair desse trecho o modo como Lacan se permite articular estrutura e subjetividade, ao situar a lógica subjetiva implicada no Édipo examinado em termos das estruturas de parentesco, tema que retomarei no próximo capítulo. 
Vale destacar que, conforme Lacan avança em seu ensino em direção ao real5 como o impossível de ser simbolizado, as divergências com o antropólogo revelam-se mais marcadamente. O parentesco entre as disciplinas não se rompe - apesar de o caminho empreendido por Lacan levá-lo em direção ao real, a uma revisão da primazia do simbólico - pois ele se estabelece a partir de uma afinidade que está na base das duas. Ambas, “[...] nos confins de todos os conhecimentos sobre o homem, formam por certo um perpétuo princípio de inquietude, de retificação, de crítica, de contestação do que por ventura pode ter parecido, por outro lado, definitivamente adquirido" (FOUCAULT, 1966, apud KOLTAI, 2010).

Para encerrar este item dedicado a circunscrever a família a partir dos encontros entre a psicanálise e a antropologia, um pequeno trecho em que ouso reconhecer um LéviStrauss "lacaniano" ao situar a ilusão humana de driblar a falta quando esta resulta sempre incontornável: "Até nossos dias a humanidade sonhou apreender e fixar este instante fugitivo em que foi permitido acreditar ser possível enganar a lei da troca, ganhar sem perder, gozar sem partilhar" (LÉVI-STRAUSS, 2008, p. 537).

\section{3 - A influência de Durkheim}

O grupo reduzido formado pela família moderna não se apresenta, com efeito, ao exame, como uma simplificação, mas antes como uma contração da instituição familiar [...] Esse sentido é dado precisamente quando, à luz desse exame comparativo, se apreende o remanejamento profundo que conduziu a instituição familiar à sua forma atual; reconhece-se, ao mesmo tempo, que é preciso atribuí-lo à influência prevalente que assume aqui o casamento, instituição que devemos distinguir da família. Daí a excelência do termo 'família conjugal', pelo qual Durkheim a designa (LACAN, 1938, p. 16).

O parágrafo acima é um dos dois únicos momentos em que Lacan cita Durkheim em seu escrito de 1938. Ainda que Lacan não o explicite, o sociólogo francês representou uma forte influência na sua argumentação teórica referente à família. Peusner (2009) relata

\footnotetext{
${ }^{5}$ O Real não se confunde com o termo "realidade". Trata-se de um termo inventado por Lacan para fazer referência ao que escapa, ao que resiste à simbolização, ao que "não cessa de não se inscrever". $O$ conceito de Real organiza a teoria e a clínica lacaniana e não é fácil de ser apreendido, Lacan o traduziu de inúmeras formas ao longo de seu ensino. Kaufmann (1996) o define da seguinte maneira: "Ao Real será conferido o estatuto de vazio, de impossível de ser representado, situado fora de todo campo demarcável" (p. 445). Em A Terceira (1974), Lacan afirma que "o real é o que retorna sempre ao mesmo lugar. O acento deve ser colocado no 'retorna'. É o lugar que ele descobre, o lugar do semblante” (p. 9).
} 
ter se surpreendido ao debruçar-se sobre esse escrito de Lacan e identificar que, na ocasião de sua produção, o interlocutor de Lacan era Durkheim - e não Lévi-Strauss, como se supunha -, mais especificamente uma aula daquele, proferida em 1892 e intitulada "A família conjugal". Veremos mais adiante que outro autor estudioso das relações entre a psicanálise e as ciências sociais, Markus Zafiropoulos, não partilha da mesma surpresa em relação ao um Lacan durkheimiano na base do texto de 38 .

A aula em questão foi aberta com o seguinte comentário: "Chamo com este nome a família tal como está constituída nas sociedades surgidas de sociedades germânicas, ou seja, nos povos mais civilizados da Europa moderna" (DURKHEIM, 1892, apud PEUSNER, 2009, p. 92, tradução livre). Comentário particularmente eficaz para surpreender os leitores de Lacan com a escolha de Durkheim como um interlocutor! Mas avancemos no texto de 1892, na tentativa de localizar o que nele foi inspirador para Lacan, mesmo que já possa adiantar que não partilho da posição de Peusner - que vê na escolha da noção de 'família conjugal' um risco de se arrastar a psicanálise para uma concepção biológica da família - e que aprecio o aporte de Markos Zafiropoulos ao questionar a "contração" da qual esse modelo familiar teria sido o resultado.

Durkheim define a família conjugal como aquela que compreende o marido, a esposa e os filhos. Trata-se de uma contração da família paternal. Mas o que seria a família paternal, de acordo com o sociólogo? Seria aquela que compreende o pai, a mãe e todas as gerações surgidas deles, salvo as filhas e seus descendentes.

Continuando, o sociólogo francês acentua outra particularidade da família conjugal: a intervenção sempre crescente do Estado, e, no mesmo parágrafo, utiliza o termo "família moderna" para designar o tipo de família em questão6. O autor parece nomear como "família conjugal" o que Roudinesco (2003) define, conforme veremos no próximo capítulo, como "família moderna". O que chama a atenção é que, embora ambos os autores situem tal modelo familiar como sustentado no laço conjugal, o fazem de modos distintos, Roudinesco (assim como JULIEN, 2000) aponta para a escolha sexual como um diferencial importante em relação à família tradicional, portanto, para o fortalecimento do laço entre os cônjuges, e Durkheim para aquilo que resta - o conjugal - depois que os filhos crescem, conforme veremos mais adiante.

\footnotetext{
6 “Tal é a zona central da família moderna” (DURKHEIM, 1892, apud PEUSNER, 2009, p. 125).
} 
Durkheim assinala que não haveria nada que recordasse o estado de dependência perpétua que era a base da família paternal e da família patriarcal (a família patriarcal é anterior à paternal). Peusner (2009), por sua vez, se pergunta sobre o que seria tal dependência e se de fato ela teria sido abolida:

Qualquer psicanalista teria objetado: 'Como não há nada? Coloque qualquer pessoa no divã e se dará conta de que a gente continua tão dependente das gerações anteriores como o foi em qualquer outro estilo de conformação familiar. Somente há que fazê-lo falar' (p. 93, tradução livre).

Para corroborar essa afirmação, recorre à noção de família como continuidade psíquica entre as gerações, formulada por Lacan em 38. Mas, convenhamos, Durkheim se refere a uma dependência jurídica, propõe uma leitura sociológica da família e, nesse contexto, sua afirmação não só procede como é partilhada por outros pesquisadores pois, entre as principais mudanças que implicaram a passagem de um modelo tradicional de família (leia-se patriarcal) para a família moderna, estão o fortalecimento do laço conjugal e a participação crescente do Estado $^{7}$ no campo da família.

É neste ponto que o risco preconizado por Peusner parece descabido, já que Durkheim toma a família como objeto do ponto de vista jurídico, ocupando-se da evolução do direito que a regula. Lacan toma emprestado de Durkheim a concepção de família conjugal, adotando o entendimento deste de que ela seria o resultado de uma contração da instituição familiar; entretanto, nem por isso a reduz a um fenômeno de menor complexidade ou a um fato biológico.

Ainda descrevendo as particularidades da família conjugal, Durkheim faz o seguinte comentário:"Estamos então, na presença de um novo tipo de família. Posto que os únicos elementos permanentes nela são o marido e a esposa, uma vez que todas as crianças deixam cedo ou tarde a casa paterna, proponho chamá-la "família conjugal'" (DURKHEIM, 1892, apud PEUSNER, 2009, p. 124, tradução livre).

A originalidade do comentário reside no fato de o laço conjugal ser definido como o que resta dessa modalidade de família, enquanto outros autores que abordam as mudanças

\footnotetext{
${ }^{7} \mathrm{O}$ autor situa duas maneiras pelas quais o Estado pode intervir: ao exercer o direito de correção do pai e ao requerer a interdição do adulto.
} 
experimentadas pela família do ponto de vista histórico situam o laço conjugal como o que a funda. Contudo, e então talvez concorde com Durkheim, mas talvez por motivos alheios aos que ele apontaria, penso o laço conjugal como aquele que funda e também como aquele que resta, não se reduzindo aos laços parentais, testemunhando um desejo que está para além dos filhos: transmissão necessária e fundante da subjetividade.

Durkheim pontua, na sequência, outra particularidade deste modelo de família: a desestabilização do coletivismo familiar $^{8}$. O situado aqui pelo autor é o prenúncio da sobreposição, na família, das necessidades individuais sobre as do coletivo? O seguinte trecho comprova essa hipótese e a previsão de Durkheim em relação ao laço social que passaria a vigorar e a predominar em um futuro próximo: "Pode então ser certo que tal apagamento do coletivismo que caracteriza nosso direito doméstico não seja um acidente passageiro, mas pelo contrário, se acentuará cada vez em maior medida [...]" (DURKHEIM, 1892 apud PEUSNER, 2009, p. 128, tradução livre).

A noção de coletivismo é uma noção jurídica, relativa aos bens comuns a uma família. O fim do coletivismo está associado ao fato de que as coisas deixaram de ser um cimento da sociedade doméstica, de forma que esta se tornou absolutamente pessoal. Outrora, os laços que derivavam das coisas prevaleciam sobre os que surgiam das pessoas. Durkheim parece se ressentir do fato de que a família deixe de ser regulada pela manutenção do patrimônio e passe a ser edificada em torno dos sentimentos afetivos consumados no laço conjugal. O coletivismo que se retira da sociedade doméstica passa a concentrar-se na sociedade matrimonial

Para finalizar o comentário sobre o texto de Durkheim de 1892, vejamos como ele o conclui:

Tais são as conclusões gerais que se depreendem deste curso. O progresso da família foi o de concentrar-se e personalizar-se. A família se contrai cada vez mais; ao mesmo tempo as relações nela tomam um maior caráter pessoal devido ao apagamento progressivo do coletivismo doméstico. Enquanto a família perde terreno, o

\footnotetext{
${ }^{8}$ Foi um grupo de historiadores ingleses que, na década de 70, questionou as bases para a lei de contração familiar, postulada por Durkheim. Para explicar a estrutura da família e sua extensão, os sociólogos levavam em conta as condições demográficas e as condições jurídicas, particularmente a herança. Neste sentido, a idéia de um comunismo familiar, ou seja, a vigência de grandes famílias em um período anterior não foi absorvida como natural pelos ingleses dado que na Inglaterra prevalecia a divisão igualitária entre os herdeiros e uma tradição de organização restrita à família (ZAFIROPOULOS, 2002).
} 
casamento - pelo contrário - se fortifica (DURKHEIM, 1892 apud PEUSNER, 2009, p. 132, tradução livre).

No cenário atual, como veremos no capítulo 2, o que vemos fortificar-se são as novas formas de família, instituindo laços parentais que, muitas vezes, não só independem do casamento e mesmo de uma conjugalidade, mas também do ato sexual.

Depois de examinar mais detidamente a aula ministrada por Durkheim, não encontro justificativa para a preocupação manifestada por Peusner com os riscos de não se avaliar a extensão que teria na fundamentação de Lacan sobre a família o fato de ter tomado de empréstimo a noção de família conjugal do sociólogo francês ${ }^{9}$. Peusner destaca como central em Lacan o entendimento de que a família conjugal sustenta e mantém o irredutível da transmissão. No texto Nota sobre a criança, de 1969, Lacan atribui a função de resíduo à família conjugal, mas também enfatiza o exercício das funções parentais, pretendendo descolar a operacionalidade da função das figuras que ocupam os lugares de pai e mãe. Reitero que a especificidade da psicanálise ao tomar a família como objeto, marcada definitivamente na Nota sobre a criança, mas já presente no escrito de 1938, reside no caráter não redutível ao biológico das funções materna e paterna (adultos geradores), traduzindo a família em uma estrutura hierárquica, que prevalece na primeira educação, na repressão dos instintos e na aquisição da língua materna, desempenhando um papel fundamental na transmissão da cultura.

Agora, se as formulações de Durkheim sobre a família conjugal não levam Lacan a uma visão biológica da família, observo que há no texto do sociólogo francês que serviu de base para o Lacan de 38 dois pontos que podem ter contribuído para nos arrastar para algumas das confusões que persistem na atualidade no que diz respeito à família. $\mathrm{O}$ primeiro é o reconhecimento no que o autor define como "fim do comunismo familiar" de uma crise na família, de uma desestabilização como não se viu anteriormente. E o segundo é a assunção de uma linearidade entre a forma pela qual a família se apresenta e a constituição psíquica das crianças (Durkheim considera que a união livre é uma sociedade conjugal na qual as obrigações não existem, e, por isso, é uma sociedade imoral na qual as crianças desenvolvem taras morais).

\footnotetext{
9 “Proponho, então, que desconhecer o problema teórico implícito (a concepção e construção da noção de 'família conjugal'), produz como efeito atrelar uma concepção sociológica, biológica e ideológica ao campo do fazer clínico" (PEUSNER, 2009, p. 122, tradução livre).
} 
Ao investigar as influências do pensamento durkheimiano no texto de Lacan de 1938, deparei-me com o livro de Markus Zafiropoulos, intitulado Lacan y las ciencias sociales - la declinación del padre (1938-1953). Nesse trabalho, o autor dedica-se a oferecer subsídios para o descarte da lei de contração da instituição familiar como originária da família conjugal, postulada por Durkheim e adotada por Lacan em 1938. Zafiropoulos também mostra como o sociólogo francês influenciou a produção de Lacan e questiona com veemência a noção de declínio social da imago paterna, assumida pelo psicanalista naquele momento de seu ensino e situada na base de dois grandes problemas intimamente relacionados e ainda presentes na atualidade: a nostalgia do patriarcado e o "chamado ao pai" recorrente em algumas práticas clínicas e instituições.

\section{4 - A tese do declínio da imago ${ }^{10}$ paterna e suas conseqüências}

O declínio da imago paterna, para Lacan, estaria intimamente ligado à dialética da família conjugal, constituindo uma crise psicológica, possivelmente relacionada ao aparecimento da própria psicanálise ${ }^{11}$.

Essa tese de Lacan é recusada por Zafiropoulos. Suas pesquisas levam-no a questionar tal declínio, dado que as bases da noção de família conjugal, adotada por Lacan a partir de Durkheim, estavam fincadas em um erro e a descoberta deste, na opinião de Zafiropoulos, deveria fazer ruir toda a construção sustentada. O autor também discorda de que a psicanálise tivesse surgido a partir desse cenário - do declínio do pai - e, para tal, recorre aos pais dos pacientes de Freud para mostrar que não é devido à carência ${ }^{12}$ daqueles que seus filhos adoeciam. Apresentarei a seguir os principais eixos da pesquisa

\footnotetext{
${ }^{10}$ Em Chemama (1995), imago é definida como "termo introduzido por C.G. Jung (1911) para designar uma representação tal como o pai (imago paterna) ou a mãe (imago materna), que se fixa no inconsciente do sujeito e ulteriormente orienta sua conduta e seu modo de apreensão do outro. A imago é elaborada em uma relação intersubjetiva, podendo ser deformada em relação à realidade" (p. 105). De acordo com Laplanche e Pontalis (1998), "a imago e o complexo são noções próximas, relacionam-se ambas com o mesmo domínio - as relações da criança com o seu meio familiar e social. Mas o complexo designa o efeito sobre o sujeito da situação interpessoal no seu conjunto; a imago designa uma sobrevivência imaginária deste ou daquele participante dessa situação" (p. 235).

11 "Apenas o sublime acaso do gênio talvez não explique que tenha sido em Viena - então centro de um Estado que era o melting-pot das formas familiares mais diversas, das mais arcaicas às mais evoluídas, dos últimos agrupamentos agnáticos dos camponeses eslavos às formas mais decadentes do casal instável, passando pelos paternalismos feudais e mercantis - que um filho do patriarcado judeu tenha imaginado o complexo de Édipo. Seja como for, são as formas de neuroses dominantes no final do último século que revelaram que elas estavam intimamente dependentes das condições da família” (LACAN, 1938, p. 60).

${ }^{12} \mathrm{O}$ tema da carência do pai será examinado no próximo item.
} 
de Zafiropoulos: antecipo, todavia, que não partilho de algumas das posições que o autor assume.

Embora Lacan, no texto de 1938, faça apenas duas referências a Durkheim, vimos que toma de empréstimo do sociólogo a concepção de família conjugal. Como costuma ser seu estilo, Lacan não alardeia a influência; contudo, ela é valorizada por Peusner (2009) ao comentar o referido texto e mais ainda por Zafiropoulos (2008). Este último se detém nos escritos de Lacan de 1938 a 1953, sustentando a tese de que este teria se deixado influenciar por um equívoco da formulação durkheimiana - o de que a família conjugal seria a resultante de uma contração da instituição familiar -, que interpreta como uma transferência, pelos intelectuais da época, do romance familiar do neurótico ao campo da sociologia.

Em La novela familiar del neurótico (1908) Freud formula que, para alcançar um estado normal, e até mesmo para o próprio progresso da sociedade, o indivíduo deve liberar-se da autoridade de seus pais. Se, para a criança pequena, os pais são a única autoridade e o desejo que prevalece é o de se parecer com eles, conforme se desenvolve e conhece outros pais, a criança começa a discordar daqueles e a criticá-los. "Intensos impulsos de rivalidade sexual" estão na base desse processo, no qual a criança se lança em uma intensa atividade imaginativa, que se manifesta no brincar e, mais adiante, nas relações familiares, e que Freud designa como a novela familiar dos neuróticos: “[...] a imaginação da criança se dedica, pois, à tarefa de liberar-se dos pais menosprezados e a substituí-los por outros, geralmente de categoria social mais elevada" (FREUD, 1908, p. 1362, tradução livre).

Como de costume em seus escritos, Freud preocupa-se com o modo como suas formulações podem ser compreendidas por seus leitores e os adverte de que tal atividade imaginativa aparentemente plena de hostilidade não é de fato tão malévola, pois conserva "sob tênue disfarce" todo o afeto primitivo da criança pelos seus pais. Nesse sentido, e acompanhando Freud, observa-se que tal atividade da criança é sustentada por uma nostalgia daqueles tempos nos quais os pais eram dignos do desejo de parecer-se a eles. Na novela familiar do neurótico, não se trata, portanto, de eliminar o pai, mas de exaltá-lo. 
Não é preciso ir mais longe para situar o ponto sobre o qual incide a analogia proposta por Zafiropoulos: ao transferir o romance familiar do neurótico ao campo da sociologia, o autor localiza em sua base uma nostalgia e uma exaltação do pai.

Vejamos agora a base teórica que permite a Zafiropoulos identificar o erro durkheimiano e lançar sua interpretação de que a lei da contração familiar seria resultado do "romance familiar dos sociólogos". A lei de "contração da estrutura familiar' que fundamenta a noção durkheimiana de 'família conjugal' foi questionada na década de 70 por um grupo de historiadores de Cambridge:

Que as famílias de antigamente eram pouco numerosas - de quatro a seis pessoas, em média -, e isso não só na Inglaterra, mas em toda Europa. Que, ademais, a maioria destas famílias eram de 'tipo conjugal', que as famílias ampliadas eram ainda menos freqüentes que em nossos dias e que quase nunca se encontravam a família troncal $^{13}$ e outros tipos de famílias 'polinucleares' (LASLETT, 1972, apud ZAFIROPOULOS, 2002, p. 139, tradução livre).

Esse grupo questionou não só a veracidade do modelo proposto por Durkheim, mas o de outro sociólogo francês, Fréderic Le Play, cuja obra é anterior e marcadamente reacionária e nostálgica em relação à família patriarcal, modelo familiar a seu ver natural e de excelência. Os historiadores de Cambridge questionaram até mesmo a formulação de que a passagem da família extensa à família nuclear teria ocorrido no momento da revolução industrial.

Zafiropoulos reconhece em Le Play e em Durkheim uma idealização da família patriarcal e se lança nessa analogia, a meu ver questionável, que não só retira dos investigadores acima toda a sua credibilidade como os infantiliza e os sujeita a uma interpretação psicanalítica descabida.

Assim, o pragmatismo dos historiadores ingleses teria posto um fim à ilusão partilhada pelos sociólogos franceses, que se constituiria em uma formação imaginária coletiva e da qual seria preciso fazer um luto. Na base dessa "recomendação" está a preocupação de Zafiropoulos com os especialistas, entre eles psicanalistas, que ainda se referem a

\footnotetext{
${ }^{13}$ Le Play descrevia uma família troncal ideal típica como aquela que reunia um grupo de pelo menos 18 pessoas, isso porque supunha que em um período de vinte e cinco anos, as mães tivessem até 20 filhos, qualquer que fosse seu meio social (ZAFIROPOULOS, 2002).
} 
essa "formação imaginária", induzindo a um chamado nostálgico ao pai, a uma figura autoritária e até tirânica, que tem aparecido de forma crônica nas instituições, na esfera política e é assumido até mesmo por alguns clínicos (no campo "psi” tal "chamado ao pai” aparece abundantemente, seja na quantidade de evocações ao pai, seja na variedade das formas pelas quais se sugere ou se orienta que estas devam ocorrer). Embora eu partilhe com o autor a preocupação em relação ao "chamado ao pai", parece-me excessivo atribuí-lo a esse suposto erro (pois no caso se tomaria a produção da Escola de Cambridge como verdade única) subjacente à definição da família conjugal como uma contração da instituição familiar. $\mathrm{O}$ "chamado ao pai" me parece muito mais uma decorrência do condicionamento da operatividade da função paterna ao lugar social do pai e, portanto, da tese do "declínio da imago paterna". No item "As declinações do pai em Lacan", esse tema será discutido mais detidamente.

Sob a autoridade de Lacan, muitos psicanalistas de renome sustentaram diversas teses a respeito do "declínio da imago paterna". Entre estes, Zafiropoulos situa Elizabeth Roudinesco, que estaria concorde com a tese de que a invenção da psicanálise seria uma resultante do declínio da família patriarcal. Ainda que não concorde com o autor na crítica que faz a Roudinesco, partilho de sua preocupação com o risco de que aqueles que se instituem como herdeiros do pensamento lacaniano reproduzam a confusão entre o pai simbólico e o pai de família, recaindo em uma lógica ambientalista ou ainda enaltecedora do patriarcado.

A leitura de A família em desordem, de Roudinesco, a meu ver não conduz a uma visão idealizada do patriarcado (a autora afirma que Lacan se opunha à idéia de um restabelecimento da onipotência patriarcal) e tampouco a um discurso nostálgico. Não dá margem, ainda, a uma visão da psicanálise como reparadora do declínio social do pai, e, tampouco, a uma confusão entre o pai como função e o pai de família. A autora, assim como Lacan em 1938 e outros autores, atribui à efervescência cultural da Viena daquela época a invenção da psicanálise. No entanto, essa afirmação não implica estabelecer uma relação unívoca causal entre a invenção da psicanálise e o declínio da imago do pai, embora este apareça como um dos componentes das mudanças em curso na sociedade vienense. 
Localizar mudanças em curso no discurso social de uma época, o que Lacan em 1953 define como alcançar a subjetividade de sua época, é um trabalho delicado e necessário, que não se confunde com estabelecer uma relação linear, causal, entre história e subjetividade, conforme veremos no próximo capítulo.

Zafiropoulos (2008) resume da seguinte maneira quatro ideias essenciais decorrentes da posição assumida por Lacan na década de 1930:

a bancarrota do pai de família é um fato comprovado;

o declínio da instituição familiar estaria na origem da invenção da psicanálise;

Freud estaria empenhado em revalorizar o pai;

Lacan, em seu retorno a Freud, aspiraria reintroduzir a imagem do pai como essencial para a organização da família e para a estruturação subjetiva das gerações.

E conclui:

\begin{abstract}
Não basta, com efeito, repetir simplesmente que a imago paterna - e mais em geral o grupo familiar - está em declínio para dar conta da atualidade de nossos mal-estares modernos (e inclusive de nossos estados fronteiriços); ademais, há que saber antropológica e clinicamente de que se fala. Também é preciso saber sobre que fonte nos apoiamos para diagnosticar com certeza a causa de nossos infortúnios e até da invenção da psicanálise, nada menos (ZAFIROPOULOS, 2002, p. 28, tradução livre).
\end{abstract}

Tort (2008) partilha da mesma posição, pontuando que, se não se esclarece o discurso sobre o declínio do pai, não se pode fazer frente às posições alarmistas dos que assumem que nossas sociedades estão destruindo as condições de subjetivação; como se os velhos tempos fossem estruturantes, e os atuais fossem decadentes. O filme "Meia noite em Paris" ${ }^{14}$, de Woody Allen, é precioso ao mostrar como a nostalgia em relação a um tempo anterior atravessa a história da humanidade. No filme, o protagonista, imobilizado em sua produção como escritor, pela crença de que os grandes feitos neste campo já ocorreram, de que os grandes artistas não existem mais (crença que de fato não parece lhe ser exclusiva!), escapa à meia noite para um tempo passado no qual tem o privilégio de desfrutar da companhia de seus artistas preferidos, como Picasso, Hemingway, Dalí e etc. Conhece a bela Adriana, amante de Picasso, e se surpreende ao

\footnotetext{
${ }^{14}$ Título original: Midnight in Paris (2011).
} 
reconhecer nela também uma nostálgica dos tempos passados. Numa destas noites maravilhosas, tropeça com um Degas nostálgico do Renascimento. Só então nosso mocinho retorna ao presente e passa a encarar Paris à luz do dia, o que, afinal de contas, não é tão mau assim!

Como vimos, a leitura de Os complexos familiares na formação do indivíduo permite identificar a importância que Lacan conferia ao grupo familiar na estruturação do sujeito, assim como pressentir o valor que a função do pai começaria a assumir nos seus escritos. Zafiropoulos destaca que, naquela época, Lacan acreditava ser maior a fecundidade do complexo de Édipo se o valor do pai na família também o fosse. Conforme veremos a seguir, não há vestígios dessa relação direta entre o lugar do pai na família e a operatividade da função paterna no Lacan que veio depois, de modo que não encontro motivos para que vários autores e leitores de Lacan tenham permanecido presos a essa versão. Tal fato é importante dado que a posição assumida por Lacan em 1938 sobre o declínio da imago social do pai foi o que lhe valeu a crítica de familiarista.

No entanto, cabe ponderar que Lacan, em 1938, ainda não dispunha de importantes formulações para situar com maior clareza as diferenças entre o pai de família e o pai em sua função de resíduo - trabalho ao qual se dedicou com afinco em seus escritos e seminários -, o que poderia ter levado seus leitores a confundir tais instâncias.

Além de tomar como inquestionável o erro detectado pela escola de Cambridge, Zafiropoulos localiza outro erro, que seria uma decorrência do primeiro, mas cuja extensão seria maior para o referencial freudolacaniano. Afirma que a declinação histórica do valor social do pai de família é falsa, pois assim como a família é, desde sempre lábil, o valor do pai e o seu lugar na família também variam de acordo com o período histórico ou a localização geográfica.

Para concluir, os pais de escasso valor social e inclusive a figura do pai humilhado não datam desde logo da Viena finisecular nem da França da década de 1930, mas para descrever justamente o rosto desses pais humilhados 'desde sempre' é preciso, além disso, colocar em relevo a multiplicidade de posturas paternas atualizadas por cada época (ZAFIROPOULOS, 2002, p. 170, tradução livre). 
É exatamente neste ponto que não o acompanho. Partilho da posição de que a família se modifica ao longo da história e que convivem, num mesmo momento cronológico, diferentes modos e arranjos familiares. No entanto, é inquestionável que o lugar do pai de família se modificou profundamente na passagem do patriarcado para a família moderna, passagem que pode ser descrita como uma perda histórica do poder do pai ${ }^{15}$.

Tort (2008) chama a atenção para o especial interesse da corrente lacaniana pela figura do Pai, que, mesmo não se fixando sobre a confusão entre o trivial pai social e a função simbólica do pai, não elimina a questão: "Qual é a relação entre o que desaparece ante nossos olhos dos poderes dos pais e o universal da função paterna?” (p. 13). Para o autor, o declínio do pai, e agora a simetrização dos lugares de pai e mãe, levam à inquietação sobre o modo como se erigirá a função paterna e, portanto, sobre a constituição do sujeito. Resta examinar se esse interrogante procede ou não, e posso já adiantar que ele divide os psicanalistas. Para ultrapassá-la, será necessário estudar as declinações do pai em Lacan, as articulações possíveis entre estrutura e história, e as origens e os discursos subjacentes ao neologismo parentalidade, o que farei ao longo dos próximos capítulos.

Zafiropoulos conclui seu livro desferindo um golpe final: "É muito surpreendente que Lacan tenha seguido os passos de Durkheim sem reconhecer em sua lei de contração da família o romance familiar neurótico transladado pelos intelectuais ao campo da sociologia" (2008, p. 182, tradução livre); e acrescenta que, mesmo com as grandes diferenças existentes entre Le Play, Durkheim e Lacan, os três se sentiram fascinados por uma espécie de ilusão familiar originada no romance da grande família patriarcal.

Talvez agora seja possível hipotetizar por que autores que tiveram contato com a obra de Zafiropoulos (como PEUSNER, 2009) nem por isso abandonaram todas as decorrências das afirmações de Lacan registradas no escrito de 1938, pois, se o rigor que o primeiro reclama aos sociólogos em questão é plenamente justificável, as hipóteses que apresenta sobre os motivos que teriam levado a seus erros de procedimento me parecem exageradas, sob o risco de atirar ao descrédito toda a

\footnotetext{
${ }^{15}$ Esse tema é tratado com rigor e profundidade por Elizabeth Roudinesco no capítulo 1 - Deus pai, em $A$ família em desordem.
} 
produção daqueles, assim como dos que neles encontraram inspiração, como o Lacan de 1938.

A leitura do texto de Durkheim que serviu como referência para Lacan, o exame do texto de Lacan de 38 e o estudo da crítica de Zafiropoulos me permitem afirmar que sim, Lacan em 38 dá margem para a psicanálise familiarista, para uma visão linear da relação entre o pai na sociedade e o pai na família. Mas não se encontra vestígio dessas formulações no ensinamento de Lacan que se sucede. Ele arranca definitivamente a função do pai de sua presença na família. Vale lembrar que importantes aspectos destacados pelo autor em relação à função da família (adultos geradores) estão na base para o que virá depois em termos da família como resíduo. O Lacan de 38 já aceitava o jogo das evoluções culturais e se deixava trabalhar por elas, não se afligia com o afrouxamento dos laços familiares e, assim, fazia resistência à leitura de que as mudanças na sociedade equivaleriam a uma crise na família.

\section{5 - Do pai de família ao pai como resíduo: as declinações do pai em Lacan}

A retomada do Lacan de 38, da aula de Durkheim e da crítica de Zafiropoulos consistiu em um esforço para limpar o "movediço" a que a questão do pai parece ainda nos arrastar. Consistiu também em preparar o terreno para acompanhar como Lacan se propôs a trabalhar essa questão em seu ensino, em construções sucessivas, ou em "declinações" como sugere Laia (2006). Nestas, destacou a "firmeza" do pai de sua posição social ou de seu lugar na família e, produzindo um esvaziamento (sem dó nem piedade) da consistência condensada na figura do pai de família, investiu no pai fundando sua transmissão na pérèversion. É desta última que destaca a função do pai como resíduo, formulação crucial para a noção de família resíduo que pretendo circunscrever nesta tese. O percurso que farei aqui, junto com Lacan, busca separar definitivamente o pai de família, ou o pai de cada época, do pai como aquele que se levanta para responder, dando um testemunho de seu singular modo de gozo. 


\subsection{1- A questão do pai: um terreno movediço}

Como reconheceu Lacan no Seminário 5, As formações do inconsciente, a questão do pai parece nos arrastar até hoje para um "mundo tão movediço". "Movediço" remete a o que se move, muda de posição, ou é pouco firme. Como vimos, a psicanálise foi duramente criticada por ter deixado entender que o "movimento" (leia-se declínio) do pai na sociedade geraria uma desestabilização no pai de família, gerando uma "carência paterna", o que justificaria uma nostalgia do patriarcado, assim como as várias versões pelas quais o "chamado ao pai" se atualiza nas instituições e nos meios "psis". Essa confusão encontraria algum respaldo no texto de 1938, mas só até ele. E então esse movediço que permanece no que tange ao pai parece ter se perpetuado para além de Lacan.

Lacan é contundente em seus escritos, marcadamente no Seminário 5, As formações do inconsciente, ao dissociar o Nome-do-pai de qualquer concretude relacionada à pessoa do pai, suas características ou presença física, afastando-se de uma visão ambientalista, sociológica ou psicológica. Em "De uma questão preliminar a todo tratamento possível da psicose" (1965/66), o psicanalista frisa a frouxidão dos discursos que localizam a "carência paterna" na biografia ou na caracterologia do pai, carência que se desdobraria nas figuras do pai indulgente, do pai humilhado, do pai onipotente, etc. Desse modo, desloca a carência do pai na família - "não se trata de sua ausência ou presença concreta, como elemento do meio ambiente" (1957-58, p. 173) - para sua carência no complexo, cuidando para não recairmos no "rame-rame da análise sociológica ambiental" (LACAN, 1957-58, p. 197).

É preciso incluir ainda no "movediço" que envolve a questão do pai na psicanálise a universalidade do Édipo preconizada por Freud, que, critica-se, normalizaria uma “família edipiana”, situando no patriarcado a garantia da transmissão da lei paterna. Os que partilham da ideia de que a família está em crise na atualidade justamente apontam que as novas configurações familiares não poderiam dar a consistência necessária ao complexo de Édipo. Aqui, a presença da palavra consistência não é casual: é a suposta consistência atribuída ao pai - como pai de família, do qual se reclama a presença e a "normalidade" - que torna o terreno tão movediço. 
Limpar o terreno, portanto, passa por reafirmar que a psicanálise não é guardiã da família patriarcal e, tampouco, da ordem paterna; que a família patriarcal não é o modelo da psicanálise lacaniana, aliás, não se preconiza um modelo de família na psicanálise. A idéia de modelo (leia-se, ideal) é incompatível com o discurso psicanalítico. Lacan preocupava-se com uma prática psicanalítica que se inclinasse na direção da adaptação do indivíduo ao meio social, reconhecendo nela um desvio da psicanálise. Marcava que "não se trata, como se acredita, de se adaptar a um real mais ou menos bem definido ou bem organizado, mas de fazer reconhecer sua própria realidade, em outras palavras, seu próprio desejo" (LACAN, 1953a, p. 41). Esta preocupação também pode ser localizada na letra de Freud em El porvenir de la terapia psicoanalitica, ao alertar seus ouvintes-psicanalistas (trata-se de uma conferência pronunciada no $2^{\circ}$. Congresso Psicanalítico Privado) de que não devemos inculcar nossos ideais ao paciente, nem buscar modelá-lo à nossa imagem, que não devemos situar-nos como "fanáticos higienistas ou terapeutas" (FREUD, 1910, p. 1569, tradução livre).

Jutamente porque a psicanálise não é guardiã da ordem paterna, talvez Lacan tenha podido, a cada nova volta sobre a questão do pai, liberá-lo da consistência imaginária que adquirira como pai de família e garantidor da ordem social, para localizá-lo em sua função residual, independentemente de seu papel na família ou na sociedade. Nesta passagem, o pai da palavra suplanta o pai de família, e vale destacar que desembaraçarse do familiarismo não implica uma superação ou desatualização do romance familiar.

\subsection{2 - As declinações do pai em Lacan}

Declínio pode ser definido como perda de força, enfraquecimento. Declinar implica entrar em decadência, cair, perder a força, enfraquecer, mas remete também a desvio (desviar-se de um rumo, de um ponto). Segundo a gramática, declinar ${ }^{16}$ implica “acrescentar (nas línguas flexionais) terminações casuais específicas a um radical, para indicar as diferentes funções sintáticas do termo (adj., pron., subst) na oração."

\footnotetext{
${ }^{16}$ Fonte: Dicionário Aulete. Disponível no endereço eletrônico: http://aulete.uol.com.br/site.php?mdl=aulete_digital
} 
Uma torção possível dessa definição leva a tomar "declinar" como deixar cair, sem, necessariamente, enfraquecer. Da acepção gramatical, destaco "terminação casual específica" necessária para "indicar as diferentes funções do termo". Veremos se e como essas acepções e esse modo de lê-las permitem tratar o movediço do pai em Lacan como “declinações do pai”. Tal é a proposta de Sérgio Laia em "Declinações do pai em Lacan”, artigo no qual recorre ao latim para precisar o uso particular que propõe do termo declinação: "declinar um nome significa enunciar em determinada ordem as diversas formas que ele reveste segundo as funções que desempenha na frase, isto é, enumerar os seus casos” (RONÁI, 1980, apud LAIA, 2006, p. 41, grifo meu).

Retomar as declinações do pai em Lacan não implica assumir um enfraquecimento do pai. Como já fomos advertidos por Zafiropoulos e Tort, a assunção de um enfraquecimento do pai levou rapidamente à afirmação de sua carência. No Seminário 5, Lacan observa que não se sabe em que o pai é carente, portanto, a falta paterna permanece como enigmática, contrapondo-se às perspectivas que sustentam um saber sobre o que falta ao pai e que pretendem indicar como saná-la. O célebre caso do pequeno Hans é exemplar de que um pai "normal", presente e atencioso, pode falhar em sua função "normalizadora". Assim, a carência do pai não resultaria de sua falha no simbólico ou no enfraquecimento da lei, o que constituiria uma versão imaginarizada do pai, mas de uma demissão do pai Real com relação ao desejo da mãe.

Vale lembrar que o pai simbólico é o pai morto (como ser) e conservado (como significante). O pai imaginário é aquele com o qual se está em rivalidade fraterna, e o pai Real é aquele que intervém como agente da castração (PORGE, 1998). No seminário 17 (1969/70), Lacan não só reafirma o pai Real como agente da castração como é contundente ao afirmar que não há causa do desejo que não seja produto dessa operação.

Assim como o tema da "carência paterna" ganha consistência nos discursos "psis" convertendo-se em práticas de "chamado ao pai" (em orientações concretas relacionadas à presença física do pai ou às atividades que deve empreender junto aos filhos para efetivar sua função), o tema da "autoridade paterna" revela-se também alvo de uma certa confusão. Nesta, atribui-se a suposta crise na família a uma crise da autoridade paterna, logo, a restauração dessa autoridade habilitaria o pai ao exercício de sua 
função. Reconhece-se em tal leitura uma nostalgia do patriarcado; afinal, restaurar a autoridade do pai sem recair em um modelo de família patriarcal parece algo bastante improvável. Práticas que visam restabelecer a autoridade paterna identificam na consistência do pai de família a operatividade de sua função, leitura que o ensino de Lacan não autoriza. Este é um modo pelo qual o discurso social trata as mudanças que vêm ocorrendo na sociedade e na família; contudo, as declinações do pai em Lacan arrancam definitivamente a operatividade da função paterna da autoridade do pai na família e no espaço coletivo.

Lacan tinha uma especial capacidade de estar à escuta do social e, com isso, reconheceu no pai do patriarcado uma mera contingência histórica (KOLTAI, 2010). Eu não só partilho dessa posição como a formulo nos seguintes termos: a identificação do pai de família com a autoridade se constitui em um modo de sutura da falta, promovido pelo laço social e relativo a uma época, de forma que, no patriarcado, a autoridade consistiria em um modo de sutura da falta daquela época, em um dos semblantes ${ }^{17}$ assumidos pelo pai, particularizando um modo de velar a sua própria inconsistência, diante da inexistência da relação sexual. (Essa formulação vai ao encontro da leitura que será realizada no capítulo 3 sobre a parentalidade como o sintomático desta época).

A esse respeito, Lebrun (2008) formula a seguinte questão: “[...] o patriarcado foi apenas um modo de organização da sociedade contingente historicamente ou, ao contrário, resulta de uma necessidade estrutural?” (p. 247). Acompanhando-o em sua reflexão a partir dessa interrogação, verifica-se que ele não pretende "salvar o amálgama", optando pela hipótese do patriarcado como contingência histórica (LEBRUN, 2010, p. 88). Com isso, é possível discordar de autores como Melman que, em Um homem sem gravidade, faz uma amálgama entre pai e patriarcado: "Um pai não pode se autorizar por ele mesmo, só pode se autorizar pelo patriarcado. E se ele quer, a qualquer preço, se autorizar por ele mesmo, estamos lidando com o pai violento, brutal [...]" (MELMAN, 2003, p. 122). Ainda, para encerrar definitivamente esta discussão,

${ }^{17}$ Definem-se como semblantes os fenômenos que nos fazem crer que há algo ali onde não há. O semblante nos faz crer que há realidade ou verdade onde há o real. Dessa forma, sua função, na vida e na análise, é velar o real, ainda que por vezes vacile e toque o real, desvelando-o. A relação entre os sexos é a experiência na qual o real mais se presentifica. A "não-existência da relação sexual" seria uma das versões do real, e é justamente o que um semblante se esforça por subtrair, mesmo que acabe produzindo oscilações entre o velar e o desvelar. 
localizo na letra de Lacan sua posição a respeito: "O mito de Édipo faz espalhafato porque, supostamente, instaura a primazia do pai, que seria uma espécie de reflexo patriarcal. Eu gostaria de fazê-los perceber por que, pelo menos para mim, ele de modo algum parece ser um reflexo patriarcal, longe disso" (LACAN, 1971, p. 162).

No que tange ao "movediço" do pai, o tema da autoridade paterna ganha nova consistência imaginária quando se atribui uma nova razão à passagem da autoridade paterna para a autoridade parental, desta feita sustentada numa ficção jurídica, para justificar a carência do pai em nossa época, conforme veremos no capítulo 2.

Se um dos modos de abordar a questão do pai é declinando-o em Lacan, Ritvo (2000) propõe uma leitura também interessante do modo como Lacan, de uma forma geral, mas tomado pelo autor a partir do conceito de sintoma, trabalhava um conceito ao longo de seu ensino. A propósito das "deformações" às quais Lacan submete, em seus sucessivos seminários, a noção de sintoma, Ritvo diz que elas não devem ser entendidas como substituições ou complementaridades, mas sim como suplementaridade, “[...] ou seja, cada determinação tenta resolver um problema, mas ao resolver o problema que a determinação anterior não havia conseguido, provoca outro. Isso quer dizer que, de algum modo, o conceito só se fecha em torno de seu próprio vazio" (p 11.). Veremos a seguir como, no que tange à função paterna, o pai como morto passa a criar problema quando Lacan formula a noção de pai Real.

\subsection{3 - O pai de Freud é um pai morto}

A questão do pai ocupou Freud do início ao fim de sua obra. Os três mitos aos quais se dedicou podem ser considerados mitos do pai: Édipo, Totem e tabu e Moisés e o monoteísmo. Lacan os retoma, principalmente os dois primeiros, destacando a morte do pai como crucial para a psicanálise: “A morte do pai. Todos sabem, com efeito, que parece estar aí a chave, o ponto sensível de tudo o que se enuncia - e não só a título mítico - sobre aquilo com que a psicanálise lida" (1969-70, p. 125).

No complexo de Édipo o pai é aquele que transmite a interdição do incesto. Pode-se dizer que a função do pai, aqui, é articular o sujeito ao simbólico. No centro do Édipo está a castração, perda de gozo necessária à entrada do sujeito na ordem simbólica. A 
castração dá consistência e legitimidade ao gozo, por intermédio da interdição. O pai faz a criança entrar na ordem simbólica exigindo renúncia, perda de gozo. Veremos a seguir que em Lacan a linguagem se institui como tributária desta perda de gozo e que, nas declinações sucessivas às quais submete o pai, a ênfase recai no modo como este testemunha sua singular relação com o gozo, naquilo que autoriza, e não mais ao impelir à renúncia.

A universalidade do Édipo em Freud estaria fundada na percepção de desejos incestuosos universais e o complexo diria respeito ao destino incontornável do humano e não a uma mera experiência individual, "é na morte do pai que reside sua esperança de vida" (KOLTAI, 2010, p. 86). Em Lacan, a universalidade estaria na redução do mito à estrutura, ainda que sempre posta à prova pela clínica.

Em seu retorno a Freud, Lacan formulou o Édipo como metáfora paterna, visando desmitificá-lo e desfamiliarizá-1o ${ }^{18}$, transformando-o em uma fórmula lógica e universal. Vale destacar que esse trabalho não o poupou de deter-se sobre as variações do Édipo ${ }^{19}$, ou seja, de estabelecer uma relação entre a fórmula e os casos individuais, questionando-a, relativizando-a, colocando-a à prova no caso a caso. Nesse movimento, é possível reconhecer em Lacan a preocupação permanente de articular estrutura e história, mais especificamente o modo em que esta última incide na primeira, ou talvez no modo como na história singulariza-se o que é da estrutura, dados "os acidentes da história de cada um que não se deixam frequentemente reduzir à fórmula" (BROUSSE, 1997, p. 53). Os casos individuais, ao introduzir o real da clínica no universal da fórmula, também permitem "animar" a fórmula com o vivo da experiência clinica (Brousse, 1997).

Em relação a Totem e tabu, há em Lacan uma revolta com a insistência de Freud de que isso fosse real ${ }^{20}$. Para ele um pai da horda nunca existiu. "Não é por predicar um retorno a Freud que eu não posso dizer que Totem e tabu é meio torto" (1969-70, p.117).

\footnotetext{
18 "Desfamiliarizar" o Édipo representa um esforço diante das críticas que se fez à psicanálise de condicionar o Édipo às características da família burguesa-vitoriana dos tempos de Freud.

${ }^{19}$ Em conferência intitulada "As interpretações lacanianas do Édipo freudiano", Brousse (1997) trata dessas variações do Édipo retomando o caso do pequeno Hans e tira importantes conseqüências para a clínica psicanalítica com crianças.

${ }^{20}$ Caterina Koltai, em seu livro Totem e tabu, um mito freudiano, mostra que Freud oscila entre apresentar o parricídio como um fato que ocorreu em um passado distante e foi recalcado e apresentá-lo como um fato imaginário, que captura algo de essencial do real: a relação do pai com a lei.
} 
Contudo, Lacan identifica uma invariante nesses dois mitos (Édipo e Totem e tabu) e dedica-se a examiná-la: o assassinato do pai é a condição de gozo.

Totem e tabu apresenta-se como o mito fundador da função paterna. Havia uma horda primitiva dirigida por um único macho que gozava de todas as fêmeas e que privava seus filhos do acesso a qualquer uma delas. Um dia, os filhos se juntaram para matar o pai. Uma vez o pai assassinado e seu lugar liberado, diante da rivalidade fraterna, os filhos erigem uma lei ainda mais radical. "De fato, se o pai, segundo a Lei, é o pai morto, é esse o representado no Totem, ou no nome da lápide, então só há um passo a ser dado para dizer que o pai é um significante - e Lacan faz isso" (VANIER, 2005, p. 66). Lacan dá a esse significante o nome de Nome-do-Pai e situa a castração no centro de sua função.

No centro do Édipo está a castração. A função do pai é de agente da castração. A castração é o que atinge o filho e se transmite de pai para filho. Vale marcar que, se a metáfora paterna implica uma perda de gozo, ao mesmo tempo autoriza o gozo-fálico ${ }^{21}$. O pai, por natureza incerto, nomina cada filho ordenando-o em uma linhagem e inscrevendo-o na diferença entre as gerações: "O pai é de fato o genitor. Mas, antes que o saibamos de fonte segura, o nome do pai cria a função do pai” (LACAN, 1954a, p. 47).

Ainda que eu tenha feito a passagem por Totem e tabu de forma muito rápida, ficam as referências para que o leitor possa aprofundar-se. O que me importa destacar aqui é que em Totem e tabu, uma vez o pai morto é que seus filhos podem gozar (em um Lacan que se dedica a formular um "mais além da metáfora paterna", veremos que é um pai vivo, sexuado e imperfeito que opera em sua função de resíduo).

Ao tomar o pai morto como equivalente ao gozo da mãe, Lacan faz uma transposição do mito à estrutura, tomando essa equivalência como um operador estrutural. Mesmo questionando o mito de Totem e tabu, o autor assinala a segregação intrínseca à fraternidade, na qual, quando estamos todos isolados juntos, estamos isolados do resto: "seja como for, eles se descobrem irmãos, e indagamos em nome de qual segregação"

${ }^{21}$ O gozo fálico é um gozo limitado pela castração, mas acessível. Para Lacan, a castração permite o acesso a um gozo possível (enquanto para Freud a castração era o que impedia o gozo). O falo organiza o corpo em torno de um órgão isolado pelo significante (VANIER, 2005, p. 92). 
(1969/70, p. 121). A preocupação com a segregação, um traço de nossa época “estamos evidentemente numa época em que a segregação, erght!" (p. 120) - é uma constante no ensino de Lacan e é retomada pelos seus leitores em suas análises sobre o mal-estar na atualidade. A segregação é subjacente a um laço social não só fundamentado em um "nós", mas exacerbado neste "nós", evidenciando um apagamento da diferença em prol da semelhança. Essa temática será retomada no capítulo 4.

O mito freudiano, pretendendo-se real, localiza na morte do pai a interdição do gozo. Depreende-se daí que pai morto= gozo impossível. Ao propor um "para além do Édipo”, Lacan conjuga o pai como um termo do impossível. O mito seria dessa forma um enunciado do impossível, impossível que Lacan credita à linguagem uma vez que o gozo está interditado a quem fala. Ou, dito de outro modo: "toda formação humana tem por essência, e não por acaso, de refrear o gozo (LACAN, 1967, p. 362). A perda de gozo se produz pela linguagem, é decorrência da condição humana, ou seja, decorre de sermos animais capazes de fala, condição circunscrita por Lacan em termos de "seres falantes" (condição que o gato do rabino viu-se fadado a ratificar uma vez que se instituiu como ser falante). Creditar à linguagem a perda de gozo necessária à subjetivação é negá-la como tributária da função paterna. Nesse sentido, a entrada na linguagem decorre dos cuidados iniciais que o Outro preconiza com o filhote humano a partir de seu desamparo inicial. Freud, já no Projeto de uma Psicologia se ocupava com a ação específica realizada pelo Outro Primordial, descrito no texto como Próximo cuidador (Nebenmensch) como fundamental ao convocar o bebê a inscrever-se no universo da linguagem.

Aceder à linguagem implica um consentimento (trata-se de uma escolha forçada) em uma perda. Sujeitar-se ao Outro, ao desejo do Outro, operação formulada por Lacan nos termos da alienação, é condição necessária para separar-se, em um segundo tempo lógico. Alienar-se constitui uma escolha forçada, ainda que esse termo encerre um paradoxo: é possível escolher não se alienar, não se sujeitar à linguagem? Tal decisão excluiria a possibilidade do advento do indivíduo como sujeito, o que remeteria à clínica do autismo. Importa aqui destacar que a linguagem é o que faz sujeito, o que Bernardino (2006) formula nos seguintes termos "[...] é a linguagem, esta estrutura, que ‘adquire' a criança!’ (p. 25). 
O termo "escolha forçada" remete ao exemplo clássico de Lacan sobre a decisão diante da ameaça do assaltante: "A bolsa ou a vida! ${ }^{22}$ ". Pode-se escolher dar a bolsa e permanecer com a vida (sempre com a perda aí implicada), mas pode-se hesitar e, ao tentar permanecer, perder a bolsa... e a vida! Ou bem, ainda que a bolsa permaneça, já não haverá alguém para usufruir disso em proveito de que a vida se perdeu...

A retomada do Édipo, no seminário 17, foi marcada por um esforço de Lacan em separar a castração do Édipo, separá-la do pai, tomá-la como real, como efeito da linguagem. Veja-se que a interpretação freudiana do Édipo faz equivaler o pai à castração, vela que o pai é castrado, "ao se colocar o pai em posição de exceção por causa de seu assassinato, vela-se a sua própria castração” (BROUSSE, 1997, p. 72). Esconde-se que a castração vem de outro lugar que não do pai: a castração passa a instituir-se como uma função da linguagem e não mais como uma função do pai. Com isso, há um deslocamento do Édipo como traumático para o traumático inerente à inscrição do sujeito na ordem simbólica, na linguagem, implicando sempre o real da perda de gozo.

Não há causa do desejo que não seja produto da operação da castração. "A castração é a operação real introduzida pela incidência do significante, seja ele qual for, na relação do sexo. E é óbvio que ela determina o pai como esse real impossível que dissemos" (LACAN, 1969/70, p. 135). Nesse sentido, "se é pai por causa de." (LACAN, 1969/70, p.137).

\subsection{4 - O Nome-do-Pai}

O Édipo freudiano foi interpretado por Lacan como metáfora paterna: "falei então nesse nível sobre a metáfora paterna. Nunca falei do Complexo de Édipo a não ser desta forma" (LACAN, 169-70, p. 118). A metáfora paterna consiste na substituição do significante Desejo-da-Mãe pelo significante Nome-do-Pai. Ao introduzir o Nome-doPai, Lacan declina o pai reduzindo-o a um nome que não se confunde com traços biográficos sociais ou familiares de um pai. Na metáfora paterna, os personagens que compõem a trama edipiana são desimaginarizados (há uma redução do imaginário ao simbólico). O pai é um significante (Nome-do-Pai) e a função paterna opera como

\footnotetext{
${ }^{22}$ Cf. Seminário 11, Os quatro conceitos fundamentais da psicanálise.
} 
metáfora - pela substituição de um significante por outro. Vale lembrar que a metáfora implica substituição e desaparecimento e, também, que haja um mais de sentido. Retomando: ao desejo materno substitui-se o Nome-do-Pai (representante de um desejo materno outro, não voltado para a criança). Dessa forma, assim como o pai, a mãe é tomada como um significante, o Desejo-da-Mãe ${ }^{23}$, que comporta uma incógnita (x): a criança se pergunta sobre as idas e vindas da mãe. A criança interessa-se pelo desejo da mãe, “[...] na medida em que seu desejo é o desejo do desejo da mãe" (LACAN, 1957/58, p. 188). Esse desejo está no lugar de uma ausência, de uma falta. "O desejo da mãe é neste momento uma palavra para definir ausência" (BROUSSE, 1997, p. 54). O seguinte trecho permite antever os riscos que Lacan preconiza para aqueles que permanecem aprisionados no campo do desejo da mãe:

O papel da mãe é o desejo da mãe. É capital. O desejo da mãe não é algo que se possa suportar assim, que lhes seja indiferente. Carreia sempre estragos. Um grande crocodilo em cuja boca vocês estão - a mãe é isso [...] É o que se chama falo. É o rolo que os põe a salvo se, de repente, aquilo se fecha (LACAN, 1969/70, p. 118).

A metáfora paterna consiste na substituição de uma ausência por uma palavra que venha tapar a ausência e, no seu reaparecimento como uma proibição (pai morto e mãe proibida). Aqui se atualiza a função da lei, caracterizada pelo pai morto, portanto simbólico, a função da falta ou ausência caracterizada pela mãe proibida, portanto real, e a função significante encarnada pelo falo, o "a mais" que se produz como resultado da operação metafórica. O pai é assim o que permite ao sujeito sair do impasse imaginário.

O Édipo comporta uma função de normalização. Essa função não incide apenas "na estrutura moral do sujeito, nem em suas relações com a realidade": diz respeito à assunção de seu sexo" (LACAN, 1957/58, p. 171), permitindo que "o homem assuma o tipo viril e que a mulher assuma um certo tipo feminino e se reconheça como mulher e se identifique às suas funções de mulher" (LACAN, 1957/58, p. 171). A norma estabelecida graças à intervenção simbólica do Nome-do-Pai sobre o Desejo-da-Mãe é a norma fálica, que tenta regular a existência da diferença sexual sem restringi-la à diferença entre os genitais masculino e feminino. A pertinência à norma fálica deve-se

\footnotetext{
${ }^{23}$ Pode-se ler no significante "Desejo da mãe" tanto a mãe como desejante quanto a mãe como desejada. Veremos a seguir como para que o pai se apresente em sua pérèversion é crucial que possa instituir a mãe como objeto causa de seu desejo como homem.
} 
à incidência da metáfora paterna. "O Nome-do-Pai é a capacidade normativizante do pai enquanto ele não se conforma a uma média, mas 'faz rachar' as normas maternas para instituir novas. Sua perversão é a versão da mudança de norma que ele institui por relação ao desejo da mãe" (PORGE, 1998, p. 41).

Portanto, não é a normalidade do pai (pai normal) o que permite que ele seja um normatizador nem é esta a normalidade que resulta do Édipo entendido como uma função de normalização. Aqui não está em jogo a "normalidade" como uma oposição ao patológico, mas uma normatização como neurose: um pai como "neurotizante", na medida em que incide sobre a metáfora paterna, o que independeria de sua presença física. Mais uma vez Lacan separa a "normalidade" do pai de sua posição "normal" na família. "O pai Real nada mais é que um efeito da linguagem e não tem outro real" (LACAN, 1969/70, p.134). É neste contexto que o autor não perde a oportunidade de separar o pai Real do pai da realidade, pois, traduzindo-se em um efeito da linguagem, a função paterna não corresponde ao lugar do pai na família ou na sociedade, mesmo "numa sociedade que não lhe dá evidentemente um grande papel” (169/70, p. 133).

Reproduzo a seguir, de forma resumida, os três tempos do Édipo em Lacan. No primeiro tempo, o pai intervém como símbolo e a criança se oferece como assujeitado (ao desejo da mãe). Lacan (1957/58) destaca que se trata de um capricho "articulado" pela mãe, o pai existe aqui de forma velada, pois o significante designado como Desejoda-Mãe já é metaforizado pelo Nome-do-pai. Há uma dimensão nominal do pai que é determinante para esta articulação.

No segundo tempo, o pai aparece como interditor. É a declinação do pai mais conhecida e divulgada e que poderia deixar acreditar que a função paterna se traduz em termos da autoridade do pai, como vimos. Este intervém não mais de forma velada, mas intermediada pela mãe. Vale frisar que "a privação [é] da mãe, não da criança" (LACAN, 1957/58), já que a divulgação do pai como interditor e representante da lei pode deixar entender que a proibição recairia sobre a criança. Aqui é a mãe que consente em transmitir a lei suportada pelo pai (LAIA, 2006).

A saída do Édipo depende de um terceiro tempo, que marca a consolidação da norma fálica na orientação da trama sexual de um sujeito. O pai não é mais velado nem 
mediado, "o pai é revelado na medida em que ele tem" o falo (LACAN, 1957/58), dá à mãe o que ela deseja. $\mathrm{O}$ falo se revela como o dom de um pai à mãe de seu filho. O pai dá provas de que tem o falo e pode efetivá-lo para além de um objeto de privação para a mãe.

O falo se constitui como um objeto privilegiado na ordem simbólica. A relação da criança ao falo se estabelece uma vez este é o objeto do desejo da mãe. Esta relação, no entanto, é mediada pela palavra do pai, e, nesse sentido, a metáfora paterna é o que permite fundamentar o desejo inconsciente. E, mais que isso, é a partir dessa operação que um sujeito se localiza na diferença sexual. $O$ falo não é um pênis, um órgão ou um objeto real, não é uma fantasia nem um objeto. É um significante (LACAN, 1953d). Trata-se do mesmo significante para ambos os sexos, marcando a substituição do desejo materno por um nome e também a substituição do órgão pelo semblante (LACAN, 1956/57)

\begin{abstract}
A introdução do falo como significante da diferença sexual no ser falante tem como conseqüência a passagem ao parecer, ao semblante. No ser falante, o sexo é organizado não apenas pela diferença anatômica, que tem sua importância, mas é determinado pela linguagem. $\mathrm{O}$ falo produz uma substituição do ser com o parecer. $\mathrm{O}$ que implica que tudo que tem a ver com o sexo para os humanos está do lado do semblante. Quando se fala em ser homem ou ser mulher é sempre do lado dos semblantes (BROUSSE, 1997, p . 59).
\end{abstract}

As posições masculina e feminina são conseqüências do Édipo, o mais de sentido que se produz tem a ver com a sexuação. Essas posições são fundadas no "império dos semblantes que necessita do império dos significantes, por sua vez organizado pelo significante fálico, que tem a ver com o Nome-do-Pai” (BROUSSE, 1997, p. 60).

A sexuação é o processo de eleição de uma posição sexuada e de um objeto sexual. Não há sexuação sem Édipo. No Édipo unem-se a filiação e a sexuação, e a família é o lugar ao mesmo tempo fundamental, mítico e real desse processo. Não há sexuação sem filiação. Não há eleição do sexo, da posição sexual na cadeia das relações sem uma posição na genealogia (BROUSSE, 1997). Antes de formular a teoria dos nós ${ }^{24}$, Lacan

\footnotetext{
${ }^{24} \mathrm{O}$ nó borromeu é uma figura topológica que articula os três registros, simbólico, imaginário e real, apresentada por Lacan pela primeira vez no seminário Ou pior, aula de 9 de fevereiro de 1972. Ao se cortar algum desses nós, os outros se veem imediatamente soltos, "este nó consiste estritamente no fato de
} 
atribui ao Édipo o valor de nó: une a estrutura do sujeito à sua história singular. O Édipo se institui, portanto, no nó entre estrutura e subjetividade. Une a perspectiva estrutural com a temporal (LACAN, 1953d).

Desse modo, o Édipo é o que permite instalação de uma posição inconsciente no sujeito: uma posição sem a qual o sujeito não poderia se identificar a um tipo ideal de seu sexo, uma posição que permite ao sujeito situar-se como parceiro de um outro e que permite acolher as necessidades da criança que pode advir da relação sexual com outro (Lacan, 1953d).

Com a metáfora paterna, Lacan desfamiliarizou o Édipo, mas Brousse (1997) nota que ela não leva em conta o pai da realidade, só o nome, e assim só fala dos pais como mortos. A realidade dos pais, das mães, são acidentes ou tem poder de determinação? Se não há pai senão traumático ${ }^{25}$, que lugar dar ao trauma? Essa também parece ser a pergunta de Lacan sobre o pai como morto. A noção de pai morto cria dificuldades quando a noção de pai Real é abordada por Lacan: como fica a questão da morte como estando na origem? Talvez tenha sido a partir deste interrogante que Lacan tenha trabalhado a função do pai na direção de um pai vivo, cuja eficácia reside não apenas na interdição, mas no testemunho e na conseqüente autorização de um gozo, como veremos a seguir.

A abordagem formal do complexo de Édipo não dispensa a presença dos corpos em jogo nessas relações. Para avançar em relação a este ponto, Laia (2006) refere-se a uma diferenciação estabelecida por Laurent entre o pai como função simbólica e o pai como existente, mostrando que a dimensão formal do Édipo está referida a uma corporeidade. A formulação do Édipo em termos da metáfora paterna é um movimento importante no sentido do "movediço" mobilizado pela questão do pai. No entanto, “[...] a metáfora paterna não se processa sem algum tipo de incidência sobre a existência" (LAIA, 2006, p. 50) e implica também um resto.

que três é o seu mínimo [...] É, a saber, que se de três vocês rompem um dos anéis, eles ficam livres todos os três, ou seja, os outros dois se soltam" (LACAN, 1974/75, p. 5).

${ }^{25}$ Lacan chamava o traumatismo sexual, estrutural, de "troumatisme", que pode ser lido tanto como buraco no real como um truque do sujeito. No lugar desse furo, o sujeito inventa algo, um truque, para preenchê-lo. 
Propor um tratamento ao resto pode ser algo fecundo em uma época em que se pretende que não haja resto! Naparstek (2006) lembra que Freud já apontava para o quanto o resto poderia ser fecundo ao tomar os sonhos como resto diurno. Lacan, no fim de seu ensino, toma o resto como aquilo que causa, declinando o pai em uma versão que leva em conta o gozo; mais que isso, alça-o a uma condição crucial na transmissão paterna.

\subsection{5- Mais além do Nome-do-Pai}

A formalização em termos da metáfora paterna não é a ultima de Lacan sobre o pai: ele declina o pai mais além do Nome-do-pai. Em RSI (1974/75), o psicanalista apresenta uma nova declinação que dá um tratamento ao que resta da operação da metáfora paterna: o objeto $a$. Os corpos agora são tomados como sexuados e a função paterna pode ser definida a partir de um trecho que é recortado e trabalhado pelos lacanianos uma e outra vez, no qual Lacan formula a noção de pérèversion: um pai só tem direito ao amor e ao respeito de uma mulher se tal amor for pai-versamente orientado, isto é, se ele fizer de uma mulher a causa de seu desejo. A pérèversion, novidade dessa declinação, comporta um pai desejante, sexuado, que não coincide mais com o pai dos três tempos do Édipo (velado, mediado e revelado). Porge (1998) situa as articulações apresentadas em RSI como uma solução para os problemas colocados pelo Nome-dopai, de modo que a suspensão de 1963 (a interrupção do seminário sobre os nomes do pai na primeira aula) não é mais relembrada por Lacan.

Ao instituir a função do pai como pérèversion, Lacan mais uma vez lança mão dos jogos de palavras - sempre tão apreciados por ele - fazendo valer a referência à sexualidade e propondo uma versão sexuada da função paterna, introduz nesta a dimensão do gozo, o pai como aquele que autoriza um gozo. Ao declinar-se como pérèversion, o pai funciona como vivo/desejante, como "modelo de uma função" de gozo. Modelo e exceção articulam-se aqui da seguinte maneira: "é preciso que qualquer um possa ser exceção para que a função de exceção se torne modelo [...] "Aí está o que deve ser um pai, na medida em que só pode ser exceção" (LACAN, 1974/75, p. 23).

No Édipo da metáfora paterna, o simbólico prevalecia sobre o real e o imaginário. Em RSI, ponto de chegada da reflexão de Lacan sobre o para além do Édipo freudiano, não há mais predominância do simbólico. Nessa declinação, o pai deixa de ser o significante 
de uma função e constitui-se em uma existência singular, um uso de gozo particular que habilita outras exceções (LAIA, 2006).

A nomeação, num primeiro tempo em Lacan, decorre do registro simbólico. O Nomedo-Pai equivale ao pai esvaziado de gozo, ao pai morto. Quando se trata do pai vivo e gozante da pérèversion, a nomeação é também de ordem imaginária e real. No entanto, o pai é um vetor de uma encarnação da lei no desejo, ele é existente, mas também semblante; como vetor, ele suporta, mas não consiste. Nesse sentido, não equivale a um ideal (aqui não estão em jogo suas virtudes morais), tampouco deve confundir-se com excepcional e recai em uma impostura quando pretende consistir (ou confundir-se com) a lei:"[...] nada pior que um pai que profere a lei sobre tudo: sobretudo nada de pai educador" (LACAN, 1974/75, p. 23, grifo meu). O pai Real se define a partir da causa (como causa sexual) e não pode operar a partir de enunciados edificantes. Estes apontariam para uma versão de pai “purificado de gozo" (Laurent, 2007).

O pai Real se configura como um pai que permite e dá. Um pai que porta a lei, diferente do pai de direito ou do pai que intervém simbolicamente. É importante desprender-se da idéia de um pai que se identifica à função do interdito para abrir margem para um pai cuja lei é menos oposta e mais articulada à lei do desejo: a função do pai é unir e não opor o desejo à lei.

Na mesma linha, a eficácia do Nome-do-Pai residiria no fato de que alguém se levanta para responder (LACAN, 1971, aula de 16 de junho de 1971), um nome chamado para que alguém fale. Nesta declinação, não importa tanto o nome dado ao pai, mas o nome dado pelo pai ao nominar, "O que só quer dizer que o Pai enquanto Nome, não quer dizer nada de início, não só o pai como nome, mas como nomeador" (LACAN, 1974/75, p. 64). A nominação faz buraco, e Lacan é enfático, para alguma coisa ex-istir é preciso que haja buraco.

O pai Real recoloca a questão do pai encarnado e, nesse sentido, consiste em uma formulação central para articular a família como resíduo, o romance familiar e o modo como pai e mãe se conformam em semblantes ao encarnar as funções. 
Domingos Infante ${ }^{26}$ (2010) avança significativamente ao precisar em que consiste a nominação do pai Real. Ao nominar, o pai Real, no mesmo golpe, atarraxa um nome ao gozo, cria um real e singulariza ${ }^{27}$. Quando se nomina, o pai cria um real, um pai real, que se submete à lei; nominar implica localizar um gozo e cifrá-lo, implica um desejo. As nominações criam um real, separam a criança do campo materno e a alienam na linguagem. Ao nominar, o pai Real dá testemunho de que um sujeito singular tem um gozo específico. Infante é contundente ao afirmar que para revelar uma implicação de gozo o pai Real tem que ser encarnado.

O pai, em sua pai-versão, como existente, afeta os corpos e localiza um gozo. É graças a um pai que pode se inscrever em um corpo a marca de uma satisfação singular e contingente (LAIA, 2006).

Bruno (2003) também partilha da posição de que o pai Real tem que ser encarnado, alguém de carne e osso que não seja somente o portador abstrato de uma função, mas que assuma o risco da paternidade. Assim, não se trata de um pai virtual, ainda que a eficácia de sua palavra não resida em sua presença física. Dolto (1989) destaca a função simbólica do pai de sua presença física ao referir-se a pais que iam ao exército, mas mantinham uma relação epistolar com os filhos, escrevendo a cada um uma carta mensal, respondida individualmente.

Nessa perspectiva, o pai Real opera ao nominar um desejo especificado (um desejo não anônimo, como define Lacan ao circunscrever o que é irredutível numa família). Ao final dessa operação, pontua Bruno, o sujeito assume sua exceção, ou seja, o sujeito se separa do gozo do Outro, separa-se para se servir do pai. A extração do pai Real faz borda (BRUNO, 2003). Nesse sentido há pais e não pai, porque há modos de gozo.

Como há pais, o Nome-do-Pai multiplica-se em tantos nomes quantos forem os suportes à sua função, não se sustenta mais na ordem simbólica e como portador da interdição. A pai-versão se funda em uma pluralização da função paterna, autoriza um gozo e, para tal, não pode consistir em um pai morto. Mas é preciso que o pai seja reconhecido como

\footnotetext{
${ }^{26}$ Em transmissão oral realizada no Seminário sobre o Sinthoma em 2009.

${ }^{27}$ Singular remete ao latim singularis cuja raiz é sem que significa uma só vez (YUREVICH, 2009, p. 117).
} 
um semblante: "o semblante do pai é o signo de que houve transmissão do pai, naquilo que o divide, a saber, o real de seu modo de gozo" (SANTIAGO, 2006, p. 86).

Se o pai, como morto, permite que o identifiquemos à perfeição, um pai vivo e gozante comporta a imperfeição. Assim, se o pai ideal é uma fantasia do neurótico, só pode sêlo enquanto morto. O exame dos discursos públicos em vigor sobre a parentalidade ${ }^{28}$ parte da hipótese que estes vão na direção da promoção de um ideal no que tange ao exercício dos papéis de pai e mãe, dando consistência a noções como "competência parental" e oferecendo a certeza e a assepsia no lugar da imperfeição (do gozo, nem se fala!). Nesse sentido, me pergunto sobre os efeitos que estes discursos podem ter para os pais, ou seja, para estes poderem dar lugar à imperfeição na transmissão (imperfeição necessária para a subjetivação contingente).

Com um pai gozante e imperfeito, não há garantia, e "onde não há garantia, onde há uma lacuna no código, há lugar para a iniciativa, há lugar para a decisão, para a causa do desejo" (ZENONI, 2007, p. 8), para a invenção, termo caro a Lacan no fim de seu ensino. Nessa última declinação, o pai perde consistência para converter-se em um semblante: "ele tampa o buraco, fazendo crer que não há buraco" (ZENONI, 2007, p. 8), velando a falta de consistência e, no mesmo movimento, dando testemunho da maneira particular pela qual dá conta da inexistência da relação sexual. Um pai confere uma ficção lá onde existe um real, confere um semblante no lugar do impossível: seu modo particular de gozar é o que lhe dá alguma consistência. Ao nominar, o pai Real habilita a invenção.

Por outro lado, no prolongamento do que foi exposto no seminário As formações do inconsciente, a respeito do pai real, a noção de pai será, a partir de então, e definitivamente, abordada não sob o ângulo do parentesco, mas sob o da aliança homem-mulher, sob o ângulo, portanto, do efeito "colateral" da posição de desejo do pai sobre a constituição subjetiva da criança. Não se enfatiza a dissimetria ou a hierarquia entre os papéis dos pais, mas sim a diferença sexual, homem-mulher, no casal de pais (ZENONI, 2007, p. 9).

Esse trecho de Zenoni é central para que avancemos nas articulações entre família e parentalidade. A família como resíduo (reduzida às condições necessárias para que haja

\footnotetext{
${ }^{28}$ Uma das vertentes pelas quais o neologismo "parentalidade" comparece na atualidade, tema que será abordado no capítulo 3 .
} 
sujeito) não se confunde com o lugar do pai na sociedade (e, portanto, não varia conforme a época) e opera desde que a diferença sexual prevaleça e que, de posse de um desejo particularizado, não-anônimo, alguém se levante para responder. Adianto ao leitor que a família (em sua função de resíduo) tampouco estaria ameaçada pela paridade entre os sexos ou pela divisão da responsabilidade entre pai e mãe, uma vez que ambas não se confundem com a transmissão da diferença sexual.

Vale marcar que, na família, o gozo aparece de forma velada e que a tendência é tentar conjugar sem resto. É nessa perspectiva que pai e mãe não são mais que semblantes, velam a falta, uma vez que o real des-cobre o semblante, mas reconhecem e testemunham a relação que estabelecem com esta. Numa época em que conjugar sem resto e o empuxo a gozar são imperativos, o pai Real, em sua péréversion, ao testemunhar uma relação possível com o gozo, reintroduz a dimensão do gozo na família e atualiza não só a inexistência da relação sexual, mas a singular saída que arma diante desta.

\section{6 - Os Complexos familiares}

Ao introduzir o tema dos Complexos Familiares no texto de 38, Lacan situa, ao mesmo tempo, o ponto no qual a aproximação com a sociologia ${ }^{29}$ se faz necessária dado o objeto de estudo em questão e o ponto no qual comparece a especificidade do referencial psicanalítico diante do mesmo objeto: “[...] a família, como objeto e circunstância específica, nunca objetiva os instintos, mas sempre os complexos" (LACAN, 1938, p. 19).

Na segunda edição de El sufrimiento de los niños, Pablo Peusner inclui uma segunda parte, organizada a partir de um seminário que proferiu em Buenos Aires em 2003, intitulado "Elementos para uma teoria lacaniana da família". Introduz o tema da família em psicanálise com uma advertência - assim como fizera ao trabalhar cuidadosamente o tema do sofrimento das crianças, atrelando-o a uma temporalidade -, pontuando que é preciso ter com a família o mesmo cuidado que temos para que o sujeito não seja uma

\footnotetext{
29 "É na ordem original de realidade constituída pelas relações sociais que se deve compreender a família humana. Se, para assentar esse princípio, recorremos às conclusões da sociologia, ainda que a soma dos fatos com os quais ela o ilustra ultrapasse o nosso tema, é porque a ordem de realidade em questão é o objeto próprio desta ciência" (LACAN, 1938, p.19)
} 
pessoa de carne e osso, para não a reduzirmos a um grupo de pessoas de carne e osso, com o mesmo material genético e o mesmo sangue. Adverte ainda sobre os riscos implicados na tradução do termo parents (os pais, pai e mãe) do francês ao espanhol (o que valeria também ao traduzi-lo para o português), pois parents são também aqueles que compõem os ascendentes de uma pessoa e, ainda, parent é qualquer pessoa com a qual se tenha um laço (destaca que o dicionário Gran Robert não especifica que esse laço deva ser sanguíneo) de parentesco.

É preciso, portanto, checar nas traduções de textos ou conferências de Lacan se a referência é "aos pais" ou "aos parentes", uma vez que essa confusão não deixa de ter efeitos na leitura do texto de Lacan de $1938^{30}$. Peusner precisa ainda que o erro de tradução desse termo nos deixa totalmente atados à idéia de família biológica, e frisa que, em 1938, Lacan conhecia muito bem a noção de "família conjugal"31 e pretendia que sua noção de "complexo familiar" tomasse distância em relação àquela.

Proponho agora que acompanhemos o modo pelo qual Lacan destaca da família os complexos familiares e depois as constelações familiares. Se a noção de complexo está já em Freud e situa-se na base do escrito de Lacan de 1938, as "constelações familiares" aparecerão como uma invenção lacaniana.

Lacan define o complexo sempre em oposição ao instinto, atribuindo ao primeiro um caráter social, cultural. Posto que a ordem humana subverte toda a fixidez instintiva, o complexo é antinômico ao instinto e pertence ao domínio da cultura, e esta, diz Lacan, é uma consideração essencial para quem quer explicar os fatos psíquicos da família, entendida como o lugar de eleição dos complexos mais estáveis e mais típicos.

Se Freud instituiu a noção de complexo atribuindo-lhe um caráter inconsciente, Lacan atualizou seu papel de organizador no desenvolvimento psíquico e propôs incluir os fenômenos conscientes em seu estudo das relações dos complexos com a família, entre

\footnotetext{
${ }^{30}$ Esse comentário de Peusner sobre a tradução de parent vem fortalecer o de Miller (1984) sobre a tradução do título do escrito de Lacan. A advertência recai sobre o fato de que a compreensão de um texto pode ficar comprometida caso não haja o cuidado necessário na tradução.

${ }^{31}$ O termo aparece no texto de Lacan pela primeira vez na página 16, já referido ao modo como Durkheim o emprega.
} 
os quais destaca o complexo do desmame, o complexo de intrusão e o complexo de Édipo $^{32}$.

Miller (1984) comenta que o modo como Lacan apresenta o conceito de complexo o eleva ao estatuto de conceito chave da teoria do desenvolvimento e da psicopatologia. Para o autor, o conceito em questão é operatório, uma pré-estrutura, "uma antecipação do conceito de estrutura" - presente na referência ao social -, uma vez que o conceito de estrutura falta a Lacan no momento da elaboração desse escrito.

A ênfase posta sobre o social - obrigatória nessa Enciclopédia - e sobre o cultural como sendo o que especifica o social no homem, um cultural que é feito de sedimentações da comunicação, já anuncia a noção de simbólico pela afirmação, chocante em todos os sentidos para o leitor da época, de que o que a psicanálise verifica é a dominância dos fatores culturais (MILLER, 1984, p. 3).

É em O mito individual do neurótico, de 1952, que Lacan institui a noção de constelação familiar e situa sua inspiração nos astrólogos para forjar este termo:

A constelação - por que não, no sentido que dela falam os astrólogos? -, a constelação original que presidiu ao nascimento do sujeito, ao seu destino e quase diria à sua pré-história, a saber, as relações familiares fundamentais que estruturam a união de seus pais [...] (LACAN, 1952, p.19).

Seriam ainda componentes da constelação familiar as lendas, as tradições familiares e os traços que especificam a união de seus pais.

No texto de 1952, Lacan propõe uma leitura do caso $O$ homem dos ratos, de Freud, à qual articula sua noção de constelação familiar. Recorto dois pequenos trechos:

A constelação do sujeito (o homem dos ratos) é formada na tradição familiar pelo relato de um certo número de traços que especificam a união dos pais (LACAN, 1952, p. 19)

O que de fato se vê numa visão panorâmica da observação é a estrita correspondência entre esses elementos iniciais da constelação subjetiva e o desenvolvimento último da obsessão fantasística (LACAN, 1952, p. 21).

\footnotetext{
${ }^{32}$ C.f. - Lacan, J. (1938) Os complexos familiares na formação do indivíduo.
} 
Peusner (2009) repara que em quase todos os momentos em que Lacan fala de "constelação familiar", faz referência ao "homem dos ratos". Avalia que este foi o caso em que Freud refletiu com mais profundidade sobre o problema da "constelação familiar", mas pontua que o sistema é aplicável a qualquer caso.

A 'constelação familiar' de um sujeito humano falante deve ser entendida ao modo dos astrólogos: é preciso fazê-la falar. E é preciso fazê-la falar porque permite não só estabelecer as posições de seus componentes no momento da chegada de um sujeito falante ao mundo (algo assim como uma "carta natal"), mas que também é preciso fazê-la falar para que permita 'antecipar' algo do que poderia ocorrer no futuro (no sentido do melhor horóscopo). Lacan, em $O$ mito individual do neurótico, afirma que a personalidade do paciente deve à constelação familiar seu nascimento e seu destino (PEUSNER, 2009, p. 100, tradução livre)

Em entrevista publicada no L'Express, em 1957, justamente a propósito do caso do Homem dos ratos, Lacan retoma a noção de constelação familiar. Aponta que se trata de uma constelação dramática, anterior ao nascimento, a qual se situa na pré-história de um indivíduo e é reproduzida por ele, sem ter a menor idéia de que o faz. Precisa, e isto é central, que se fosse suficiente ter uma pré-história na origem de uma consciência, seríamos todos neuróticos e que, o que é determinante, é o modo pelo qual o sujeito tomas as coisas, admite-as ou as recalca. Reproduzo um trecho do Seminário 1, no qual Lacan articula, em sua leitura do texto freudiano, a singularidade do sujeito em relação à sua história:

O progresso de Freud, sua descoberta, está na maneira de tomar um caso na sua singularidade. Tomá-lo na sua singularidade, o que quer dizer isso? Quer dizer essencialmente que, para ele, o interesse, a essência, o fundamento, a dimensão própria da análise, é a reintegração, pelo sujeito, de sua história até os últimos limites sensíveis, isto é, até uma dimensão que ultrapassa, de muito, os limites individuais (1953/1954, p. 21).

Todo o trabalho que o paciente - criança ou adulto - realiza acerca de sua história excede o limite do individual, este que já é superado desde e quando se parte da linguagem como estruturante da subjetividade. A linguagem nos antecede, e aceder a ela implica automaticamente exceder o limite individual. O lugar da família está ligado à língua que falamos, falar numa língua já é dar testemunho de um laço com a família (MILLER, 2007). 
O mito familiar, que não é da ordem que uma transmissão biológica/hereditária ${ }^{33}$, é o que excede o limite individual. A seguir, e para encerrar esta temática, recorro a dois escritores que retratam de forma intensa e contundente a beleza, mas também o horror que exceder o limite individual pode provocar no sujeito.

Vistas de cima as duas figuras perdiam a perspectiva familiar, pareciam achatadas ao solo e mais escuras à luz do mar. Os cabelos da criança voavam...

O marido repetiu-se a pergunta que, mesmo sob a sua inocência de frase cotidiana, inquietou-o: aonde vão? Via preocupado que sua mulher guiava a criança e temia que neste momento em que ambos estavam fora de seu alcance ela transmitisse a seu filho... mas o quê? 'Catarina', pensou, 'Catarina, esta criança ainda é inocente!' Em que esta prisão de amor que se abateria para sempre sobre o futuro homem. Mais tarde seu filho, já homem, sozinho, estaria de pé diante desta mesma janela, batendo dedos nesta vidraça; preso. Obrigado a responder a um morto. Quem saberia jamais em que momento a mãe transferia ao filho a herança. E com que sombrio prazer. Agora mãe e filho compreendendo-se dentro do mistério partilhado. Depois ninguém saberia de que negras raízes se alimenta a liberdade de um homem. 'Catarina', pensou com cólera, 'a criança é inocente!'. Tinham porém desaparecido pela praia. O mistério partilhado ${ }^{34}$ (LISPECTOR, 1998, p. 100/1001).

A seguir, alguns trechos extraídos da Carta ao pai, de Franz Kafka (1919), escrita aos 36 anos.

Quero tentar explicá-lo melhor: na tentativa de casamento confluem, nas minhas relações com você, duas coisas aparentemente opostas, tão fortes como em nenhuma outra parte. $\mathrm{O}$ casamento é certamente a garantia da mais nítida autolibertação e independência. Eu teria uma família, o máximo que na minha opinião se pode alcançar, ou seja: também o máximo que você alcançou; eu seria igual a você, a velha e eternamente nova vergonha seria apenas uma história. Com certeza seria fabuloso, mas é justamente aí que está o problema. É algo excessivo, não se pode conseguir tanta coisa assim. É como se alguém estivesse aprisionado e tivesse não só a intenção de fugir - o que talvez fosse realizável - mas também, e, na verdade ao mesmo tempo, a de transformar, para uso próprio, a prisão num castelo de prazeres. Mas, se ele foge, não pode fazer essa transformação, e se a faz, não pode fugir. Se eu quiser me tornar independente, na relação especial de infelicidade em que me encontro com você, preciso fazer alguma coisa que não tenha a menor ligação possível com a sua

33 “[...] assim, o que depende apenas da transmissão biológica deve ser designado como 'hereditário' e não como 'familiar' [...]" (LACAN, 1938, p. 65).

${ }^{34}$ Trecho do conto "Os laços de família", extraído do livro que leva o mesmo título. 
pessoa; o casamento é sem dúvida o que há de maior, e confere a autonomia mais honrosa; mas também está, ao mesmo tempo, na mais estreita vinculação com você. (KAFKA, 2007, p. 67)

Às vezes imagino um mapa-múndi aberto e você estendido transversalmente sobre ele. Para mim, então, é como se entrassem em consideração apenas as regiões que você não cobre ou que não estão ao seu alcance. De acordo com a imagem que tenho do seu tamanho, essas regiões não são muitas nem muito consoladoras e o casamento não está entre elas (p. 68).

No posfácio da Carta ao pai, Modesto Carone comenta a metáfora do pai de Kafka estendido sobre o mapa-múndi e lembra duas observações feitas por Adorno: “A origem social do indivíduo revela-se no final como a força que o aniquila. A obra de Kafka é uma tentativa de absorvê-la." (ADORNO apud CARONE, 2007, p. 80). A segunda ideia é traduzida por Carone da seguinte forma: “[...] quando alguém mergulha em si mesmo, não encontra uma personalidade autônoma, desvinculada de momentos sociais, mas sim marcas de sofrimento do mundo alienado" (CARONE, 2007, p. 80). O autor presentifica os comentários de Adorno para concluir com o que seria a sua leitura do fenômeno Kafka: “Transformado pelo pai em filho deste século, Kafka deu um passo adiante, próprio do artista, e se tornou um poeta (crítico) da alienação. Não é pouco para quem se considerava um fracasso" (p 80).

Nos trechos recortados vemos Kafka lidando com a dificuldade do sujeito se liberar de um pai violento e opressor: um pai que domina o continente e que permite que fiquem do lado de fora de seu arbítrio apenas pequenos pedaços, desinteressantes e desconhecidos, insuficientes para que essa suposta autonomia possa se firmar. Kakfa mostra como a subjetividade se firma para além da individualidade. Se Adorno mira as determinações sociais, chamo a atenção para o tema da herança familiar. E que herança é essa que Kafka procura elaborar e da qual procura se libertar!

Kakfa inicia sua carta dirigindo-se ao pai e à pergunta deste sobre o medo do filho:

E se aqui tento responder por escrito, será sem dúvida de um modo muito incompleto, porque, também ao escrever, o medo e suas consequiências me inibem diante de você e porque a magnitude do assunto ultrapassa de longe minha memória e meu entendimento" (2007, p. 7). 
Penso que ultrapassa também sua consciência!

\section{7 - A família como resíduo}

Na Nota sobre a criança, Lacan (1969) refere-se à "irredutibilidade de uma transmissão" localizando-a na função de resíduo exercida pela família, “[...] que é de outra ordem que não a da vida segundo as satisfações das necessidades, mas é de uma constituição subjetiva, implicando a relação com um desejo que não seja anônimo" (p. 369). O autor delimita a função da mãe, cujos cuidados levam a marca de um interesse particularizado, ainda que pela via das próprias faltas e do pai, na medida em que seu nome é o vetor de uma encarnação da Lei no desejo. (Vejam que se trata menos da definição de um pai do que da condição do exercício de sua função a partir da localização da causa de seu desejo em uma mulher).

Ainda que en passant, na Nota sobre a criança Lacan cita o fracasso das utopias comunitárias. Vale destacar que o pequeno escrito foi entregue a Jenny Aubry em 1969, período em que estas utopias encontravam-se no auge. Naquela época, as utopias comunitárias eram anunciadas não só como uma inovação, mas também como uma maneira bem-sucedida de prescindir da família. No entanto, ao introduzir a noção de resíduo, Lacan enfatizou que não há como impedir a existência de algo irredutível nas posições de pai e mãe, mesmo que destas não haja garantias. Resíduo remete ao que resta, mas também ao que permanece como irredutível. Como resto, é também aquilo que causa (NAPARSTEK, 2006). A noção de resíduo permite ainda circunscrever o que não é redutível a uma determinada época, o que permanece independentemente das formas de conjugo, das ficções jurídicas e dos discursos do especialista da família.

Em uma época na qual se pretendia prescindir da família, Lacan preocupou-se em situar que não há como eliminar o que é irredutível nas posições de pai e mãe. Na atualidade, (como veremos no capítulo 3) os discursos normativos e ortopédicos sobre a parentalidade pretendem que se prescinda da dimensão de gozo na transmissão familiar, investindo no exercício de uma parentalidade competente e asséptica. Assim sendo, Laurent (2007) preocupa-se em reintroduzir a dimensão de gozo intrínseca à família em 
sua função de resíduo: "[...] revela-se que a instituição familiar esconde, põe um véu, dissimula o traumatismo que está no centro de toda formação humana: o gozo" (p. 38). Nesse sentido, a família como resíduo particulariza o que a cultura (ou a civilização) sustenta no âmbito coletivo, ao arrimar-se sobre um limite ao gozo. Ressalto que estabelecer um limite ao gozo ou velá-lo não implica eliminá-lo do campo da transmissão familiar.

Tomar a família em sua função de resíduo habilita a posição de que ela resiste. Essa posição não se ancora em nenhum modelo de família, nem mesmo na família nuclear, como se poderia pensar. A família resiste reduzida ao que tem de irredutível, e esta irredutibilidade remete à exigência de uma transmissão, transmissão dos elementos necessários para que haja sujeito. Lacan enfatiza que tal transmissão é de outra ordem que não a natural. Sauret (1998) completa: "não há necessidade de família para fazer filhos, mas para fazer sujeitos, sim” (p. 87).

Neste ponto, duas questões se destacam: a primeira é que o nascimento de um filho não determina automaticamente a constituição das funções parentais. Estas requerem um processo delicado de reordenamento simbólico e não estão determinadas pelos aspectos biológicos daqueles que constituem as figuras parentais. A segunda é que o irredutível da transmissão não reside no fato de que haja um homem e uma mulher no exercício das funções e tampouco a existência de pai e mãe conforma naturalmente - instintivamente - as operações fundamentais necessárias à constituição subjetiva. "Esse é um ponto que tentei destacar do texto de Lacan: alguém que se apresentaria unicamente como o pai, ou seja, que não gozaria de uma mulher, deixaria a criança nas mãos do gozo do Outro por estrutura, seja esta mãe boazinha ou não" (SAURET, 1998, p. 47, grifo meu).

Para que haja transmissão é preciso que uma mãe possa também ser mulher, é preciso que um pai possa figurar-se como um homem, e uma das vias para tal é o desejo de uma mulher. Outro modo de dizê-lo seria: para que haja um neurótico, é preciso não apenas um pai e uma mãe, mas também um homem e uma mulher. É importante ainda destacar que o sujeito, independentemente dos esforços pedagógicos de seu pai e sua mãe, responde ao tipo de Outro ao qual se confronta. Com isso esvazia-se a perspectiva de que os pais podem controlar o que transmitem aos filhos e que, se forem competentes e estiverem pedagogicamente orientados, terão mais sucesso nessa empreitada. 
A transmissão familiar é de ordem inconsciente. O que se transmite, do lado do Outro parental, não é necessariamente pronunciado ou formalizado. O significante vindo deste Outro, produzido na estrutura, contido nessa estrutura, marca do corpo do sujeito. Assim, pode-se dizer que o Outro Parental exerce sua função de posse de um desejo não anônimo, oferecendo-se como um suporte concreto para que o sujeito possa animar a estrutura. O modo como o sujeito institui o Outro para si não coincide com as pretensões pedagógicas do pai ou da mãe, mas revela sua singular posição em relação ao Outro. Assim, se o Outro é decisivo, ele não decide; quem decide é o sujeito.

Lacan opera com a noção de função visando liberar-se da consistência imaginária que pai e mãe podem adquirir, e é nesse sentido que a noção de função faz obstáculo ao ideal. Mas o que é uma função? Esta não se define a partir de uma essência ou de características, e tampouco se pode definir o conjunto dos casos que a abarcam. Uma função define-se pelas realizações das variáveis que constituem seu desenvolvimento. É a partir deste ponto que Lacan declina, no final de seu ensino, cada pai, um por um, dando testemunho de sua singular versão do gozo nessa função. Cada pai comparece como um modelo, não ao incorporar um ideal, mas ao fazer operar sua função arrimada na singularidade de seu gozo, na sua pérèversion.

A operacionalidade da função materna não se confunde com o fato de uma mãe ser bondosa ou com suas habilidades ou características, também não depende de uma perfeição nos cuidados que preconiza. Na referida Nota, Lacan destaca a crucialidade do desejo da mãe, mesmo que seja "pela via de suas próprias faltas". Portanto, quando se isolam as funções materna e paterna como irredutíveis na transmissão, não estão em jogo as boas intenções dos pais ou mesmo suas competências e habilidades educacionais. Vejam que até mesmo as faltas são bem-vindas!

Operar com a noção de função permite manter o sujeito à distância do ideal e interrogar o real em jogo no nascimento da criança, ou seja, o desejo ou o gozo que ela condensa. A dimensão do gozo, portanto, está implicada na tarefa da família, naquilo que constitui sua função de resíduo, e é no centro da família como resíduo que as faltas inerentes à transmissão avalizam a imperfeição. A transmissão da diferença sexual também é inerente à família em sua função de resíduo: 
O interesse sobre a questão familiar passa pelo assunto de saber se a situação subjetiva do adulto, no campo aberto pela diferença sexual, dá ou não uma chance à transmissão de uma posição mediadora entre o desejo e o gozo, e como o faz (SOLIMANO, 2008, p. 87, tradução livre).

É importante que nos detenhamos um momento na transmissão da diferença sexual na família, pois trata-se de um tema que leva facilmente a equívocos. Essa transmissão tem a ver com a posição que, diante da diferença sexual, um sujeito assume ao situar-se do lado masculino ou do lado feminino ${ }^{35}$. Diante das mudanças no campo da família ${ }^{36}$ tem sido comum escutarmos que a diferença sexual precisa manter-se para que as condições mínimas para a transmissão sejam preservadas, o que seria outro modo de dizer que a família como resíduo se encarrega da transmissão da diferença sexual. No entanto, é preciso esclarecer que a transmissão da diferença sexual não deriva da diferença sexual anatômica, não se confunde com as diferenças sociais entre homens e mulheres (o que levaria rapidamente à conclusão de que, nas famílias nas quais não há um homem e uma mulher, não haveria as condições para a criação de uma criança) e não se alteraria com a multiplicação das orientações sexuais.

Mesmo que destaquemos ao circunscrever a família em sua função de resíduo as condições necessárias à transmissão, o modo como cada sujeito, inscrito na diferença entre as gerações e na diferença entre os sexos, vai se articular a partir desta estrutura é absolutamente singular. Este é um modo de dizer que a estrutura é necessária, mas não é garantia, que o que se arma do lado do sujeito a partir da transmissão familiar é absolutamente singular. Concordo com Sauret quando ele localiza um ponto específico e determinante, que poderia escapar ${ }^{37}$ na leitura da Nota sobre a criança:

\footnotetext{
${ }^{35}$ Lacan formula a distribuição de lugares no quadro da sexuação, lembrando que a psicanálise insiste em manter a hiância e, para tanto, tem que resgatar a lógica da diferença. C.f. - LACAN, J. (1972/73) $O$ Seminário, livro 20: mais, ainda. Rio de Janeiro: Jorge Zahar Editor.

${ }^{36}$ Tema que será examinado no capítulo 2.

${ }^{37}$ Ponto que escapou aos psicanalistas que cederam à tentação de biologizar a pulsão e identificar a causa a uma determinação complementar: "Eles fizeram crer na ideia do neurótico segundo a qual, se o sujeito está 'ferrado', é culpa de seu pai, de sua mãe, de suas deficiências orgânicas ou cognitivas, do que ele encontrou durante sua infância, da sociedade e até mesmo da interação de determinantes biopsicossociais" (SAURET, 1998, p. 30).
} 
Se eu pudesse acrescentar uma palavra, esse texto não trata nunca da 'insondável decisão do ser'. Eu lembro a vocês, para remediar um efeito de leitura, que eu sinto que se poderia imputar a resposta da criança pelo que ela é para seu pai e sua mãe. Não importa o que induza o pai ou a mãe, a resposta do sujeito é a resposta do sujeito (SAURET, 1998, p. 94, grifo meu). 


\section{Capítulo 2 - Mudanças no contexto histórico, mudanças na família}

"Não somos daqueles que se afligem com um pretenso afrouxamento do liame familiar"

(LACAN, 1938, p. 60)

De que amanhã... : diálogo é o título do livro publicado a partir de uma conversa entre Jacques Derrida e Elizabeth Roudinesco. No prefácio, esta situa o leitor a respeito da fonte de inspiração do título escolhido para esse diálogo:

De que amanhã se trata?- pergunta Victor Hugo em um de seus poemas de Cantos do Crepúsculo. E, como introdução, assinala: 'Tudo hoje em dia, nas idéias como nas coisas, na sociedade como no indivíduo, encontra-se em estado de crepúsculo. De que natureza é esse crepúsculo, o que virá depois?' Este foi o nosso ponto de partida (ROUDINESCO, 2004, p. 7)

Tomo emprestado esse belo título para introduzir este capítulo, no qual se discutem as mudanças no campo da família, articulando-as ao momento histórico atual; cabe, contudo, adiantar de que aspectos ele não tratará no que diz respeito à família na atualidade:

1 - de definir os rumos que a família deve tomar (DERRIDA; ROUDINESCO, 2004, ROUDINESCO, 2003)

2 - de promover um alarmismo em relação às mudanças no campo da família (CECCARELLI, 2007, GAVARINI, 2008, LAURENT, 2007, ROUDINESCO, 2003, TORT, 2008)

3 - de antecipar ou de traçar um veredicto sobre o futuro das crianças educadas nas novas configurações familiares (DELAISE de PARSIVAL, 2001 e 2006, DERRIDA; ROUDINESCO, 2004, JULIEN, 2000, ROUDINESCO, 2003)

\footnotetext{
${ }^{38}$ Tradução livre do trecho citado por Roudinesco disponível nas notas de rodapé: "Espectro sempre mascarado que nos segue lado a lado./ E que se chama amanhã!/ Oh! Amanhã é o grande momento!/ De que amanhã se trata?" (2004, p. 7)
} 
4 - de compactuar com uma psicanálise que se apresenta como guardiã da moral e dos bons costumes (CECCARELLI, 2007, KEHL, 2002 e 2003, ROUDINESCO, 2003, TORT, 2008)

Nessa pesquisa, pretendo distanciar-me de posicionamentos alarmistas, preditivos e normativos. Portanto, não se trata de prever o que será da família... amanhã; porém, de examinar as principais mudanças que vêm ocorrendo no campo da família e as novas configurações pelas quais tem buscado reconhecimento. Não se trata de prever as consequiências das "novidades" no campo da família, mas de situar que, neste caso, hoje já é amanhã $\tilde{a}^{39}$ !

Elizabeth Roudinesco em A família em desordem (2003) descortina um paradoxal panorama contemporâneo: se outrora os homossexuais viviam uma experiência à margem da sociedade, reivindicavam o direito à diferença, marcando em sua escolha uma transgressão, uma oposição em relação àquilo que configurava a família como instituição normatizada na sociedade ${ }^{40}$ atualmente vêm pleiteando a possibilidade de instituir-se dentro das regras que compõem o universo estabelecido em relação à família e à procriação (buscando o reconhecimento da relação conjugal, outorgado pelo $\mathrm{PACS}^{41}$ ) e o reconhecimento do direito à parentalidade ${ }^{42}$.

É certo que muitos desses modos de procriação e filiação sempre existiram, mas existiam de forma marginal, eram ignorados ou tratados como uma fatalidade. A

${ }^{39}$ Fassin (2001) faz a seguinte leitura acerca da posição da sociologia da família em relação a essas "novidades": ela se propõe a acompanhar o movimento dos costumes, não a precedê-los; ela não pretende, portanto dizer o que deverá ser (amanhã) para além do que já é (hoje).

${ }^{40}$ Fassin (2001) pontua que a discussão não se situa mais em torno da liberdade dos indivíduos, mas em torno à inscrição da homossexualidade na sociedade. Ver: FASSIN, E, (2001). La voix de l'expertise et les silences de la silence dans le débat démocratique. IN : Au-delà du PaCS - l'expertise famliale à l'épreuve de l'homossexualité. Paris : Presses Universitaires de France.

${ }^{41}$ Pacto Civil de Solidariedade (PACS) - lei francesa em vigor desde 1999 que legaliza a união entre casais do mesmo sexo, mas não supõe o direito à adoção de crianças ou à procriação medicamente assistida.

${ }^{42}$ No referido "Diálogo", Roudinesco avança um pouco mais na discussão em relação a essa demanda de "família", advertindo para o risco deste desejo de normalidade contribuir para o aumento das discriminações sociais: "Além disso, constato que os casais homossexuais tendem a querer aparecer como tão 'normais' quanto os casais tradicionais, a ponto de imitá-los às vezes de maneira caricatural. Pergunto-me então se esse desejo de normalidade cessará com a extinção das discriminações sociais ou se, ao contrário, será acentuado" (2004, p. 50) Por outro lado, Gavarini (2008) reconhece a presença de autores e discursos dissonantes ao citar que a reivindicação do jurista Daniel Borrillo de "vida familiar para todos", seja qual for sua orientação sexual, inclui a libertação de sua "função" de sistema constrangedor e das diversas "ordens" às quais ela está subordinada: "trata-se de fazer o elogio de um modo de vida tradicional, mas libertado das obrigações que lhe dariam uma ordem" (p.7). 
reivindicação, por parte dos protagonistas de tais arranjos, suscita questões que interpelam todo o tecido social (CECCARELLI, 2007).

Diante dessa demanda de visibilidade, surgem questões como: o que esta demanda representa? Que conseqüências ela tem para o modo como as relações familiares vêm se constituindo na contemporaneidade? A existência da família está ameaçada?

Vale marcar que o estudo empreendido por Roudinesco não visa a antecipar e discutir as consequiências para a educação das crianças quando os papéis parentais são desempenhados por apenas um membro da família ou por membros do mesmo sexo mas a examinar esta demanda e suas possibilidades de significação, numa perspectiva histórica, social e política.

Denotando uma posição não alarmista, Roudinesco observa que a família é eterna e não está em perigo, uma vez que se ancora em uma função simbólica e dispõe de uma multiplicidade de possíveis recomposições. Ao dialogar com a psicanalista, Derrida (2004) faz uma ressalva a seu comentário, pontuando que não falaria de uma "eternidade" de um modelo familiar qualquer, mas de uma "trans-historicidade do laço familiar". Atribuir uma trans-historicidade ao laço familiar é outro modo de afirmar que há algo de irredutível na família, algo que independe do momento histórico em que vive o sujeito, que transcende o que é relativo a uma época, o que, neste trabalho, venho formulando em termos da família como resíduo.

Se, como mencionei acima, não se trata de promover um alarmismo em relação às mudanças no campo da família nem, tampouco, de compactuar com uma psicanálise que se apresenta como guardiã da moral e dos bons costumes, é preciso discriminar a psicanálise dos dispositivos de normalização, separando-a das disciplinas que preconizam que determinada forma de família seria mais adequada à educação das crianças, assim como discriminá-la de construtos que encontrariam suas bases em uma idealização ou em uma naturalização da família patriarcal. Nesse sentido, é importante recorrer à ética psicanalítica e Ceccarelli (2007) o faz com rigor: “A psicanálise não é guardiã de uma ordem simbólica suposta imutável, produtora de uma forma idealizada de subjetivação baseada nas normas vigentes e com o poder de deliberar sobre o normal e o patológico." (p.93). 
O modelo de família nuclear (leia-se pai, mãe e filhos morando na mesma casa), mesmo que seja idealizado e que promova uma sensação de estabilidade e segurança, nunca foi sinônimo de "normalidade". Não existe uma forma de organização familiar ideal que possa garantir as condições necessárias à constituição do sujeito. "Mesmo nos casos mais normais, acontece o que acontece: há famílias ditas normais nas quais os filhos legítimos são infelicíssimos" (DERRIDA; ROUDINESCO, 2004, p. 49).

Roudinesco também questiona uma suposta normalidade inerente à família nuclear. Contudo, para compreender a forma aguerrida como o faz, é necessário situar o cenário no qual a autora introduz esse questionamento: o de discussão sobre o posicionamento das instituições psicanalíticas em relação à homossexualidade de seus membros e sobre o repúdio, por parte de alguns psicanalistas, da homoparentalidade. A autora lança mão do termo "famílias heterossexuais" e lembra de alguns casos clínicos - todos eles estarrecedores, diga-se de passagem - do que foi "a vida ordinária de certas dessas famílias 'heterossexuais' da metade do século, cujos filhos, então adultos, freqüentaram vinte anos mais tarde os divãs dos psicanalistas" (2003, p. 189). É, portanto, em meio à indignação perante os especialistas que se propuseram a testar as "aptidões psicológicas" dos homossexuais para serem pais, que Roudinesco evoca essas cenas terríveis, atribuídas a personagens da vida familiar "normal".

O fato de uma suposta família "normal" (aquela que se apresenta com pai, mãe e filhos morando na mesma casa) não ser e nunca ter sido garantia de crianças felizes e bemeducadas não é nenhuma novidade, mas o contexto atual dos debates entre especialistas e políticos tem levado os psicanalistas a se sentirem convocados a reiterá-lo. O que os psicanalistas pretendem reafirmar não está sustentado na observação empírica (e talvez os casos trazidos por Roudinesco para ilustrá-lo me parecem excessivos), mas na base da teoria psicanalítica. Como vimos no capítulo 1, ainda que se formule o irredutível da família em termos das funções materna e paterna, diferenciando radicalmente 'a(s) pessoa(s)' do pai e da mãe da operatividade de suas funções, na família não há garantias, independentemente das configurações pelas quais esta possa se apresentar.

Se é bem verdade que a família nuclear não é e tampouco pode ser vista como um sinônimo de normalidade, é verdade também que esta tem sido a forma de família identificada no imaginário social como ideal, daí as novidades apresentadas nesse 
campo poderem ser sentidas como uma ameaça. Se bem que abandonar um ideal de tal forma arraigado no discurso social gere certa resistência, essa ação não justifica o temor de que os novos arranjos familiares estariam desintegrando a família, ou que estaríamos vivendo uma crise sem precedentes.

No último capítulo de A família em desordem, denominado "A família do futuro", Roudinesco (2003) esclarece que seus questionamentos não têm um caráter alarmista e afirma também que a existência da família não se encontra ameaçada:

Aos utopistas que acreditam que a procriação será um dia a tal ponto diferenciada do ato carnal que os filhos serão fecundados fora do corpo da mãe biológica, em um útero de empréstimo e com a ajuda de um sêmen que não será mais aquele do pai, retorquimos que, para além de todas as distinções que podem ser feitas entre o gênero e o sexo, o materno e o feminino, a sexualidade psíquica e o corpo biológico, o desejo de um filho sempre terá algo a ver com a diferença dos sexos (p. 198).

\section{1 - Da conjugalidade à parentalidade}

A família "moderna", constituída o final do século XVIII e meados do XX, representa uma ruptura em relação ao modelo tradicional. Fundada no amor romântico, a família passa a ordenar-se a partir da escolha:

Há aí uma ruptura importante. Antigamente, as famílias velavam pela semelhança de identidade dos esposos: educação, mesma crença religiosa, proximidade geográfica, tradições culturais. Doravante, a sexualidade revela publicamente que há um além das identificações sociais, uma transgressão das fronteiras culturais, uma 'familiar' estranheza da relação, uma mestiçagem étnica, uma subversão na linhagem; em suma, uma alteridade mais manifesta do que nunca (JULIEN, 2000, p.11).

A família tradicional representava uma célula estável remetida a um mundo imutável. A partir da possibilidade de escolha, os laços conjugais passam a ser fortalecidos e os casamentos arranjados diminuem significativamente. A autoridade patriarcal, predominante na família tradicional, cede espaço à divisão do trabalho e da responsabilidade pelos filhos entre os esposos e à introdução do Estado como responsável pela educação das crianças. 
A modernidade impõe duas grandes mudanças que estabelecem definitivamente a divisão entre conjugalidade e parentalidade e que representam uma reorganização dos aspectos públicos e privados destas dimensões: a primeira passa a ser orientada pela escolha dos cônjuges (o caráter privado se acentua), paralelamente à entrada do terceiro social. Esse passa a dividir a responsabilidade e a autoridade sobre as crianças, inscrevendo a parentalidade em um âmbito público e intervindo cada vez mais na relação entre pais e filhos. Desse modo, evidencia-se que a distinção entre privado e público no século XX toma a forma de uma disjunção entre conjugalidade e parentalidade (JULIEN, 2000). Essa disjunção tem como efeito a privatização cada vez maior da sexualidade e culmina na concepção de um caráter público da educação.

$\mathrm{Na}$ medida em que o PACS reconhece as uniões homossexuais, mas restringe o reconhecimento legal à conjugalidade ${ }^{43}$, separa definitivamente a sexualidade do exercício da parentalidade. Se a educação das crianças é um fato público, se o Estado deve zelar pelos direitos da criança, bem, neste caso, que se restrinja ao privado o que é da ordem do sexo e que se justifique desta maneira o não-reconhecimento do direito à parentalidade nos casais homossexuais!

Vale ressaltar que a outra face dessa moeda seria a concepção de uma parentalidade sem levar em conta a ordem sexual - e para tal a ciência se apresenta em sua onipotência, pois a modernidade viabilizou o prazer sem procriação (com o surgimento da pílula e com a legalização do aborto nos países desenvolvidos) e depois a procriação sem prazer, ou melhor, a procriação sem ato sexual, por meio da procriação medicamente assistida.

Rosa (2006) se pergunta se a consequiência desse atravessamento da ciência não seria o que Lacan cunhou de "criança generalizada",4 , "em um mundo em que não existe gente

\footnotetext{
${ }^{43}$ Hamad (2002) reproduz as palavras da deputada de esquerda Catherine Tasca, registradas no Le Monde de 10 de outubro de 1998, acerca desse ponto: "Quanto aos homossexuais, isso não representará para eles uma etapa possível no sentido da adoção e da procriação medicamente assistida. Nós escolhemos - como quase todos os países europeus que, bem antes de nós, já adotaram uma legislação para as uniões registradas - excluir essa perspectiva, pois continuamos a querer para a criança uma filiação de um pai e de uma mãe".

${ }^{44}$ É no seguinte trecho que Lacan apresenta essa formulação: "Problemas do direito de nascimento, por um lado, mas também, no impulso do 'teu corpo é teu', no qual se vulgarizou no início do século um adágio do liberalismo, a questão de saber se, em virtude da ignorância em que é mantido esse corpo pelo sujeito da ciência, chegaremos a ter o direito de desmembrá-lo para a troca. [...] Haveremos de destacar pelo termo criança generalizada a consequência disso? Certas antimemórias ocupam hoje em dia o noticiário (por que são assim essas memórias? Se é por não serem confissões como nos advertem, porventura não é essa desde sempre a diferença das memórias?). Seja como for, o autor as abre com a
} 
grande ou certas antimemórias” (p. 120). Ao inscrever a filiação no discurso científico, ao tomar a ciência como um dos nomes do pai, a ordem sexual é retirada da cena familiar. Vimos no capítulo 1 que a diferença entre os sexos consiste em um fator essencial da transmissão, e suspender o que é da ordem do sexual na família pareceria promover uma transmissão asséptica, livre das faltas e imperfeições que são intrínsecas à família em sua função de resíduo. Vale lembrar que criar uma criança envolve uma atividade sexual, e esta não se refere às competências ou habilidades ${ }^{45}$ parentais, mas à posição que a criança ocupa no desejo dos pais. A sexualidade está em jogo nas primeiras relações entre pais e filhos e fixa as modalidades de satisfação que marcam as posições do sujeito.

Entre as importantes mudanças que ocorreram nos últimos anos no campo da família, diversos autores destacam a passagem da autoridade paterna à autoridade parental. A autoridade parental configura-se como um marco para o que Hurstel (2002) nomina de um mal-estar paternal contemporâneo, situando-a como uma das três linhas de ruptura que configuram o apagamento do terceiro (as outras duas seriam a introdução das ciências biológicas na procriação e o descasamento ${ }^{46}$ e a multiplicação das formas de família). A autora acredita que a noção de igualdade concede um estatuto jurídico equivalente às crianças, às mulheres e aos homens e que se revela fonte de confusão entre estatuto social, papel na família e função edípica do pai. A igualdade de estatuto, dessa forma, seria vivida como uma indiferenciação das funções e acabaria por evidenciar uma assimilação do pai à mãe.

Se os papéis familiares tornaram-se intercambiáveis, os estatutos jurídicos idênticos para pai e mãe, as funções edipianas, estas, não podem ser indiferenciadas sob pena de ver desaparecer o terceiro edipiano [...] Como então preservar a diferença das funções? Como não fazer do pai e da mãe peças intercambiáveis? (HURSTEL, 2002, p. 9 , tradução livre).

confidência, de estranha ressonância, com que dele se despediu um religioso: 'Acabei acreditando, veja só, nesse declínio de minha vida', disse-lhe ele, 'que não existe gente grande'” (LACAN,1967, p. 367).

${ }^{45}$ A ênfase nas competências e nas habilidades parentais é um dos modos pelos quais os discursos prevalentes na atualidade se particularizam no âmbito da família.

${ }^{46}$ No original demariage, termo proposto por Irène Thery (1998). Couple, filiation et parente aujourd 'hui. Paris: Odile Jacob. 
Lebrun (2004) vai na mesma direção ao destacar dois traços da evolução do direito no que tange à corresponsabilidade parental. $O$ primeiro diz respeito ao fim da não igualdade que organizava as relações entre pai e mãe, acarretando o desaparecimento do conceito de autoridade, em proveito do de responsabilidade, marcando a superioridade dos deveres dos pais em relação a seus poderes e a diminuição destes diante dos direitos subjetivos da criança. O segundo traço se refere à inversão operada pela passagem do paternal ao parental, terminando por assegurar (de fato, mesmo que não de direito) uma preponderância da mãe, em detrimento do pai. O autor acredita que a parentalidade, em sua indiscriminação de lugares, implicaria uma mèreversão (2008). Aqui ele se inspira na homofonia introduzida por Lacan ao formular a pérèversion (versão do pai/ perversão), e pretende designar o número crescente de sujeitos que, na atualidade, permaneceriam no regime materno. Na mèreversão se sustentaria a inserção da nova criança no universo da linguagem, mas se a protegeria do encontro com o pai Real. Embora eu compreenda que o autor faça alusão ao imperativo "deixar a mãe", prescrição para toda criança em toda sociedade (conforme sua formulação em conferência proferida em 2007), penso que o termo mèreversion é uma escolha infeliz diante do impacto e da subversão que o termo pérèversion representou para a questão do pai na psicanálise, como vimos no capítulo 1. Acredito que a tradução do autor poderia representar-se melhor no termo mérearrestation ${ }^{47}$, cuja designação é de um aprisionamento no campo do Outro, ou, em outros termos, a permanência no campo materno.

Segundo alguns autores, essa preponderância do materno na qual estaríamos recaindo assumiria a forma de um retorno do matriarcado ${ }^{48}$. Eles partem da observação de que a autoridade estaria mudando de natureza e que a referência quanto à autoridade, atualmente, seria a mulher. Lacan, no seminário 18, aula de 16 de junho de 1971, traz dados que contribuem para esvaziar essa discussão:

O matriarcado consiste essencialmente nisto: é que, no que concerne à mãe como produção, não há dúvida. De vez em quando a gente pode perder a mãe no metrô, é claro, mas enfim, não há dúvida sobre quem é a mãe. Não há dúvida igualmente, sobre quem é a mãe da

\footnotetext{
${ }^{47}$ Sugestão de Domingos Infante durante reunião do grupo de pesquisa do grupo de pesquisa do Núcleo de Estudos e Pesquisas em Psicanálise com Crianças em 25 de setembro de 2009.

${ }^{48}$ C.f. - Résurgence du matriarcat. Le Bulletin, n. 2, Association Lacanienne Internationale. Paris: Editions de 1'A.L.I., 2007, p. 9-40.
} 
mãe. E assim sucessivamente. A mãe, em sua linhagem, eu diria, é inumerável (p. 162).

Roudinesco (2003) também chama a atenção para os efeitos da divisão da responsabilidade entre os pais na educação dos filhos, uma diluição entre eles da autoridade; contudo, diferentemente de Lebrun, não adverte para o risco de uma preponderância do materno:

A difusão dessa terminologia, derivada do termo 'parentalidade' (monoparentalidade, homoparentalidade, etc.), traduz tanto a inversão da dominação masculina que evoquei como um novo modo de conceitualização da família. [...] De agora em diante esta não será mais vista apenas como uma estrutura do parentesco que restaura a autoridade derrotada do pai, ou sintetizando a passagem da natureza à cultura através dos interditos e das funções simbólicas, mas como um lugar de poder descentralizado e de múltiplas aparências (ROUDINESCO, 2003, p. 155).

Penso que o pai Real, em sua pérèversion e a família localizada em sua função de resíduo operam em um registro diferente das determinações amparadas no discurso jurídico. As ficções jurídicas são necessárias e organizadoras do laço social. De fato, a passagem da autoridade paterna à autoridade parental reduz as diferenças entre pai e mãe no que tange à responsabilidade social diante do filho, mas não elimina a diferença sexual, não apaga as diferenças entre as posições masculina e feminina (e mesmo a paridade não o faz, se pensarmos que ela incide apenas no estatuto social de homens e mulheres). Nesse sentido, atribuir a ruína da família à ficção jurídica que define a autoridade parental parece consistir em uma nova roupagem para a tão criticada e supostamente ultrapassada teoria do declínio social da imago do pai.

Acredito que nem as ficções jurídicas nem as ficções científicas poderão dar conta do ponto de real do que é a origem subjetiva de cada um, o que Laurent (2010b) traduz como uma malformação do desejo do qual cada um provém, uma malformação do que foi o encontro fracassado entre os desejos que trouxe cada um de nós ao mundo, um encontro fracassado entre os sexos (uma vez que "não há relação sexual", que não há como conjugar sem resto) - e não importa se são ou não do mesmo sexo - e o desejo de criança. 
Retomando, a disjunção entre conjugalidade e parentalidade corresponde à crescente intervenção do Estado na educação das crianças e aos avanços do discurso da ciência no território familiar. A família interessa cada vez mais à ciência como uma parentalidade, os discursos normativos e ortopédicos nos quais se ampara esse neologismo pretendem excluir as imperfeições e excessos característicos do drama familiar e investir nas habilidades e competências pontuais dos pais. Essa discussão será desenvolvida no capítulo 3.

\section{2 - As novas configurações familiares}

$\mathrm{Na}$ atualidade, no que diz respeito à família, é possível localizar três modos de aproximação: há os que acreditam que as novas configurações familiares podem perturbar o exercício adequado das funções parentais; há os que exaltam a experimentação nos registros da parentalidade e da filiação, e, por último, há aqueles que assumem a posição de que, apesar das diferentes e novas configurações que possa adquirir, a família resiste.

As "novas configurações familiares" são as formas pelas quais essa instituição, na atualidade, vem se apresentando. Trata-se de um outro modo de se referir à família "contemporânea" ou "pós-moderna", definida por Roudinesco (2003) como aquela que une, “[...] ao longo de uma duração relativa, dois indivíduos em busca de relações íntimas ou realização sexual. A transmissão da autoridade vai se tornando cada vez mais problemática à medida que divórcios, separações e recomposições conjugais aumentam” (p. 19).

Gavarini (2008) resume os diferentes modos pelos quais a família contemporânea tem sido abordada por sociólogos e psicanalistas, situando as principais referências nesse campo:

"democrática": família na qual se exerceria uma "paridade 49 " entre os indivíduos, homens e mulheres, adultos e crianças. É regida pelo princípio de igualdade entre seus

\footnotetext{
${ }^{49}$ Esse modelo de família parece retratar a confusão que se instaura entre a reivindicação pelas mulheres da paridade e da não-discriminação social entre os sexos e a não-diferenciação sexual do pai e da mãe e das funções parentais.
} 
membros, e as tarefas e os papéis são autodefinidos por todos ${ }^{50}$. A psicanalista situa tal modelo na produção do sociólogo François de Singly.

"relacional": marcada pela flexibilidade das alianças e pela autorregulação das relações parentais e filiais, a partir do consentimento dos cônjuges e das crianças. A vida cotidiana é regulada pela negociação.

"recomposta": composta por uma dialética entre composição, decomposição e recomposição, marcada pela instabilidade das uniões em um processo descrito por Irène Théry como descasamento ${ }^{51}$. Os laços de filiação e de parentesco são indissolúveis em comparação com a fluidez dos laços conjugais. Notadamente, retrata a disjunção entre conjugalidade e parentalidade apontada por Julien (2000) e Neyrand (2006).

"desinstitucionalizada": sustentada em laços eletivos, conforme formulação de Marcel Gauchet, que preconiza que a família se torna um assunto privado.

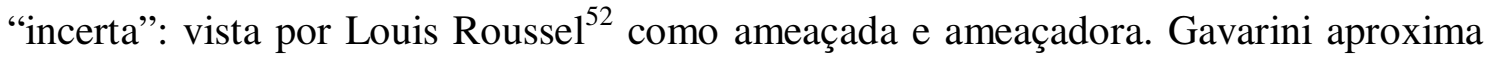
essa orientação à de Pierre Legendre (entre outros psicanalistas) que situa o enfraquecimento do pai na origem de uma crise na família e da autoridade na sociedade.

"não-institucionalizada": marcada pela marginalidade e bem conhecida pelos serviços sociais e de saúde pública, é uma família na qual se produz o que Robert Castel descreveu como desafiliação ${ }^{53}$ : a partir de uma estruturação caótica, não oferece aos indivíduos que fazem parte dela os "alicerces" que lhes dariam consistência na sociedade.

Roudinesco (2003), Julien (2000) e outros autores que se dedicam a investigar o tema da família e a contemporaneidade, partem de um panorama bastante "familiar" ao

\footnotetext{
${ }^{50}$ Diante dessa definição, me pergunto se de fato tal família existe, ou seja, se é possível fincar os laços familiares nessas bases e de que maneira.

${ }^{51}$ tradução do francês démariage.

52 "É uma família que não é mais regida como uma instituição, mas por um pacto privado. Uma família que resolve suas tensões por negociações internas [...] Uma família igualitária em que a hierarquia desapareceu no casal e se esfuma entre gerações. Uma família em que a solidariedade é simultaneamente intensa e frágil. Para dizer em uma palavra, uma família que pretende poupar qualquer terceiro significativo" (ROUSSEL, 1989 apud LEBRUN, 2004, p. 14).

${ }^{53}$ Tradução do francês désaffiliation.
} 
cotidiano das grandes cidades e das relações que se impõem neste contexto: anonimato urbano, crise da família moderna (leia-se casais separados, famílias monoparentais, famílias recompostas, famílias homoparentais e etc) e incompetência crescente dos pais na educação dos filhos. A meu ver, essa incompetência que se veria incrementada pela crença disseminada no discurso da ciência de que há um modo, um bom modo de educar, ou seja, de que existem competências parentais, que dariam conta do impossível da educação, a respeito do qual Freud já nos advertia.

Julien (2000) destaca três fatores fundamentais na concretização de uma sociedade moderna: a democracia, a laicidade e a ciência. Estes intervêm na constituição dos laços sociais na contemporaneidade, intervêm na conjugalidade e na parentalidade, ou seja, na formação dos laços conjugais e na reorganização destes laços a partir do exercício das funções parentais.

É esse cenário que leva muitos autores a se perguntarem se a família, em suas novas configurações, propiciaria as condições necessárias para a transmissão. Ainda que não se trate de alarmismo e mesmo que empreste de Sauret (1997) a convicção de que "a família resiste", as formas pelas quais as famílias se apresentam na contemporaneidade me levaram a indagar sobre a transmissão, sobre o que é preciso que se mantenha, para além das mudanças substanciais sofridas pela família nos últimos anos. Por isso, isolar a família como resíduo foi fundamental.

Contudo, localizar a família em sua função de resíduo não esgota a pergunta sobre como se articulam estrutura e contexto histórico. Situar-se em relação a esses aspectos é necessário para não recair, por um lado, em uma nostalgia da autoridade ou da tradição e, por outro, em uma supervalorização do que se introduz como novidade na esfera do discurso científico ou das ficções jurídicas.

Susana Torrado, socióloga argentina às voltas com os rumos da família na atualidade, voltando sua indagação para a função de transmissão da família, pergunta: essa função estaria assegurada nos tempos atuais?

A função de transmissão entre as gerações [...] pode ser assegurada qualquer que seja a maneira pela qual se organize a vida privada? Em especial, essa contribuição pode ser assegurada com um grau de 
autonomia individual e/ou isolamento social tão altos como os que caracterizam hoje em dia, a organização familiar? Se existe um interrogante pós-moderno, é este (TORRADO, 2003 apud PEUSNER, 2009, p. 112, tradução livre).

Peusner (2009) observa que, se a autora fosse psicanalista, responderia que sim. Para sustentar o comentário, recorre a Nota sobre a criança, texto que, conforme vimos no primeiro capítulo, pode ser tomada como um aprofundamento, mais concisa e precisamente, das ideias de Lacan já contidas em Os complexos familiares, de 1938.

É importante situar o contexto da discussão relativa às novas configurações familiares, principalmente no que diz respeito às famílias homoparentais - mas veremos que não só -, pois envolve posicionamentos e consequências relacionadas à psicanálise, à antropologia e ao direito e também de ordem política. Isso tudo não deixa de trazer efeitos para as famílias, para a educação das crianças e, principalmente, para o modo pelo qual o neologismo "parentalidade" vem ganhando consistência na atualidade.

Michel Tort (2006) aborda de modo incisivo a discussão sobre as novas configurações familiares. Esclarecendo que não se trata mais de dizer que vivemos nos tempos do declínio da função paterna - posicionamento com o qual concordo -, conduz uma reflexão em direção a uma tomada de posição menos contaminada ${ }^{54}$. O autor parece especialmente advertido em relação ao risco de os profissionais assumirem um discurso normativo ao tentar se posicionar neste campo (muito embora saibamos que em vários outros este mesmo risco se impõe). Em tal discurso, o autor localiza uma confusão entre práticas sociais e funcionamento psíquico, confusão imperante no que se refere aos efeitos do divórcio, da monoparentalidade ou da homoparentalidade para a constituição psíquica das crianças educadas nessas configurações familiares.

Tort seleciona os seguintes elementos: sexualidade, família, parentesco, sujeito, reprodução e procriação e a diferença entre os sexos e propõe nos determos em suas

\footnotetext{
${ }^{54}$ Sobretudo no contexto das famílias homoparentais, mas não só, os discursos inflamados, os posicionamentos políticos, religiosos e a militância se confundem nas posições adotadas pelos especialistas convocados a se pronunciar sobre o assunto. Tomo como exemplo a seguinte afirmação de Geneviève Delaise Parseval: "É melhor que uma criança tenha os dois pais, sejam eles do mesmo sexo, do que apenas um [...] Não se trata, portanto, de estigmatizar no que quer que seja as famílias monoparentais, mas apenas sublinhar o paradoxo legislativo francês em termos de adoção". In: Borrillo, D. e Fassin, E. (2001). (orgs.) Au-delà du PaCS - l'expertise familiale à l'épreuve de l'homossexualité. Paris : Presses Universitaires de France.
} 
articulações históricas e refletirmos sobre os arranjos entre eles, sobre os efeitos no sujeito e as medidas tomadas pelo Estado para lhes fazer frente. Definitivamente, não é pouco o que o autor propõe! [Contudo, parte deste caminho é o que pretendo empreender nesta pesquisa.]

Mas continuemos acompanhando Tort. Ele pergunta: quem define as regras? Quem define a realidade da família? E antecipa: não basta dizer que quem define essas realidades é a psicanálise, a antropologia ou o direito, quer dizer, os especialistas. Propõe outra via - a das práticas sociais - e toma como exemplo as famílias homoparentais. Seriam estas definidas pelas três disciplinas em questão ou por aqueles que a fazem? São as práticas sociais que definem um certo número de realidades ou são os especialistas? Segundo ele, essa é a questão que devemos enfrentar na atualidade.

$\mathrm{O}$ autor argumenta que a realidade das famílias homoparentais nos obriga a repensar a definição de família e a refletir sobre a própria questão das definições. Quem deve definir sobre a abertura do casamento e da filiação aos casais do mesmo sexo?Trata-se de uma decisão científica? (aqui ROUDINESCO, 2003, o acompanha) É o parentesco o autor faz referência à socióloga Irène Théry - que, para além das diferenças entre as culturas, articula a diferença entre os sexos e a diferença entre as gerações, e são as práticas sociais e a política que transformam a linguagem e a definição, não o contrário.

Num debate publicado em seguida ao texto de Tort, no que diz respeito às práticas sociais, Gérard Neyrand pontua que justamente se passou do termo parentesco ao termo parentalidade com a finalidade de ultrapassar a contradição apontada pelo primeiro. Tort concorda com essa pontuação, afinal, esse novo termo não surgiu no debate por acaso (partilho desta hipótese), e acrescenta que subjaz a ele um tipo de invenção terminológica com a qual se busca sair da contradição, retratando uma inventividade da definição prática (que não decorre de uma definição teórica). Embora considere pertinente e procedente este posicionamento de Neyrand, veremos no capítulo 3 que esta seria uma das facetas do termo parentalidade, mas há outras, que evidenciam outros discursos presentes na montagem deste termo. Resta, do referido debate, uma importante questão, formulada por Liane Mozère: mas não é o especialista, no fim das contas, que veicula o discurso majoritário? 
Fassin (2001), autor citado por Tort, pontua que a abertura do casamento e da filiação aos casais homossexuais não é mais socialmente impensável, atingindo na atualidade a categoria de passível de ser discutida. Observa que se pode ser a favor ou contra, que se pode pensar que a causa é legítima ou não, mas o que está em jogo são opiniões; podese debater, mas trata-se sempre de uma questão de valores e não de verdade. Acrescenta ainda que o tema comporta uma série de problemas, justamente porque as respostas não estão dadas e devem ser produzidas.

Penso, junto com Tort (2006) e com Roudinesco (2004), que as práticas sociais estão um passo adiante em relação ao especialista, e que não se trata de julgá-las ou normatizá-las, ou seja, estas práticas já existem, apesar e para além do pronunciamento do especialista e dos ajustes necessários em relação às políticas públicas e ao discurso jurídico $^{55}$. Então, talvez se trate de refletir se e quando cada disciplina deve pronunciarse (mesmo e claro que sempre o faça a partir de seu objeto de estudo e da ética que a orienta). Vale lembrar que na ética psicanalítica orientada pelo bem-dizer, não se pretende dizer onde está o bem!

Para mostrar que o debate e o discurso normativo ou contaminado, embora compareçam de modo mais fervoroso, não se concentram apenas em torno das famílias homoparentais, me concentrarei por um momento nas famílias monoparentais (inclusive pela sua expressividade nos lares brasileiros ${ }^{56}$ )

Acompanhemos com Roudinesco a origem do termo 'monoparental':

Em 1975, Andrée Michel, socióloga feminista, inspirou-se nas experiências da família americana para introduzir na França a expressão 'família monoparental', que serviu para designar, sem estigmatizá-lo, um modelo de família 'irregular', julgado entretanto mais negativo que o da parentalidade reconstituída (2003, p. 154)

\footnotetext{
${ }^{55}$ Reproduzo a seguir alguns dados extraídos das notas de rodapé de Roudinesco (2003): no continente americano, existem de 1 a 5 milhões de mães lésbicas, de 1 a 3 milhões de pais gays, e de 6 a 14 milhões de crianças criadas por pais homossexuais. Em Paris, entre 1990 e 2000, o número de lares monoparentais passou de 1,2 milhão para 1, 7, as famílias monoparentais representam $16 \%$ dos lares com filhos.

${ }^{56}$ De acordo com dados do IBGE, entre 1995 e 2005, na região Sudeste, as famílias chefiadas por mulheres tiveram um aumento de $35 \%$.

Fonte: http://www.ibge.gov.br/home/presidencia/noticias/noticia_visualiza.php?id_noticia=774
} 
Se a intenção, ao nomear, foi legitimar uma modalidade de família, nem por isso a representação social ali condensada foi totalmente eliminada, pois, em relação a essa modalidade de família, o discurso da expertise fez um percurso histórico que passou da vergonha à culpabilização. Contudo, é possível ler, junto com Tort (2006), que a definição se constituiu em um momento posterior à instalação de uma prática social e à reivindicação de reconhecimento por seus representantes (veremos que uma das vertentes pelas quais o significante 'parentalidade' se instituiu conformou-se em um processo semelhante).

Observemos agora algumas conclusões de pesquisas sobre mulheres sozinhas que adotam crianças (conformando famílias monoparentais), reunidas por Nazir Hamad em seu livro Adoção e parentalidade: questões atuais. MacLanahan e Sandefur (1984) verificaram que adolescentes e jovens adultos adotivos criados por mulheres sozinhas apresentaram fracasso escolar duas vezes superior às outras crianças e tinham tendência a ter filhos antes dos vinte anos. Eram 50\% mais numerosos na condição de não ter formação e estar sem trabalho do que outras crianças na mesma idade. Por outro lado, Wegar (1990) afirma que, ao contrário do que se pensa, famílias compostas por mulheres que adotam sozinhas não são mais frágeis emocionalmente que as outras, mostram laços familiares fortes e estáveis.

Hamad (2007) não se aprofunda nesses dados contraditórios, mas levanta algumas hipóteses sobre o que os justificaria. A meu ver, são hipóteses pouco convincentes, como, por exemplo, associar as dificuldades apresentadas pelas crianças a uma maior dificuldade das mães de contar sobre a adoção, pelo fato de não terem parceiros. Esses resultados, de tal forma conflitantes, podem ser atribuídos a uma certa contaminação pelas opiniões pessoais ou posicionamentos dos pesquisadores em questão?

No modo como o próprio Hamad (2007) se propõe a responder à questão "Há conseqüências em criar sozinho (a) uma criança?" verifica-se uma confusão entre dados de pesquisa e fatores de ordem imaginária intercalados com alguns elementos da psicanálise, que são tratados pelo autor de forma superficial. Indo além, acredito que o simples fato de enunciar a questão desse modo parece já revelar que o autor recorre a uma psicanálise normativa. Gavarini (2008) parece encontrar o mesmo tipo de problema 
em vários autores implicados na pesquisa sobre as mudanças no campo da família, o que traduz uma ambiguidade permanente entre ciência e convicção.

Essa ambigüidade é potencializada pela confusão que se arma entre o discurso social, as ficções jurídicas e as leituras de alguns psicanalistas, quando estes últimos confundem o fenômeno social (mães que criam sozinhas seus filhos) com a posição psíquica de uma mulher que decide ser mãe prescindindo do Outro, uma mulher que se situa "[...] como mãe sozinha em relação a seu fantasma, dando à criança um pai ideal antes que um pai imperfeito, mas da realidade" (TORRES, 2008, p. 207, tradução livre)

É preciso diferenciar uma mulher sozinha (fenômeno social) de uma mulher somente mãe (posição psíquica), pois a posição psíquica da mulher não está contida no nome. O nome apenas circunscreve o fenômeno, ou seja, sob o nome de família monoparental podemos ou não encontrar uma mulher somente mãe (aliás, uma mulher posicionada como somente mãe não seria uma exclusividade ou algo particularmente propiciado por uma determinada configuração familiar) É nessa linha que Nominé (1997) aposta ser preferível uma criança ter uma mãe suficientemente mulher - posição psíquica diante do Outro que não se deduz do fato de estar ou não casada, de ter ou não um companheiro, de enquadrar-se ou não no que se convencionou chamar de família monoparental - a uma mãe suficientemente boa (em clara alusão à formulação winicottiana).

Um bom exemplo, agora no que se refere às famílias recompostas, do modo como a família como resíduo opera em relação ao laço social predominante numa determinada época, é dado por Laurent (2007). O psicanalista retoma a pérèversion e destaca uma especificidade desta: o pai, em sua pai-versão, faz de uma mulher o objeto $a$ que causa seu desejo, enquanto a mulher se ocupa de outros objetos $a$, seus filhos. Desta forma, a pai-versão pode operar mesmo que a mulher em questão não seja aquela com a qual teve filhos.

Observa-se que, em tais casos, o especialista mais uma vez é convocado a se posicionar. Agora, entre uma demanda e as respostas que poderá gerar, não há - ou, não deveria haver - um contínuo. É imperativo que o especialista se pergunte sobre essa demanda e sobre possíveis efeitos - para além de seus campos de pesquisa - das respostas e 
posições assumidas, e que não recaia na obscenidade de elevar suas convicções pessoais ao estatuto de verdades científicas.

Fassin (2001) atribui a demanda por um posicionamento - mais especificamente no turbulento campo das famílias homoparentais - à tentativa dos políticos de buscar apoio nos especialistas para justificar a recusa às reivindicações daquelas (brevemente, o autor pontua que é a opção que lhes resta uma vez que tendem a evitar identificar-se com a discriminação homofóbica ${ }^{57}$, a se arrogar a igualdade democrática e não podem recorrer à religião - em um espaço público laico - para justificar sua posição). Localizo aqui uma versão atual de tentativa de controle pelo Estado das práticas sociais ao recorrer aos especialistas para garantir e/ou justificar práticas sociais ${ }^{58}$.

Quanto ao tema da demanda de um posicionamento aos pesquisadores, Fassin (2001) contribui com um exemplo precioso. Inquieto, ao ver o nome do pai da antropologia estrutural e o estatuto da referência cientifica invocados de maneira abusiva como expertise, pelos cientistas e também pelos políticos, Fassin endereçou a Lévi-Strauss uma carta $^{59}$, na qual perguntava se este poderia manifestar-se.

Obteve a seguinte resposta:

O leque de culturas humanas é tão amplo, tão variado (e de uma manipulação tão fácil) que encontramos sem dificuldades argumentos para apoiar qualquer tese.

Entre as soluções concebíveis aos problemas da vida em sociedade, a etnologia tem o papel de repertoriar e descrever aquelas que, em condições determinadas, se revelaram viáveis.

Esta familiaridade adquirida com os costumes os mais diversos lhe ensina - no melhor dos casos - uma certa sabedoria que pode não ser inútil a seus contemporâneos; sem esquecer contudo que as escolhas da sociedade não pertencem ao cientista enquanto tal, mas - e ele mesmo é um - ao cidadão (LÉVI-STRAUSS, 1999, apud FASSSIN, 2001, p. 110, tradução livre).

\footnotetext{
${ }^{57}$ A seguinte afirmação de Gavarini (2008) denota o modo como essa situação rapidamente se configura: "A idéia de um 'direito à criança' pode ser entendida como um direito a ser como os outros, do mesmo modo que o fato de colocá-lo em questão é rapidamente considerado signo de homofobia" (p. 7).

${ }^{58}$ Tema desenvolvido por Roudinesco em A família em desordem e por Donzelot em A polícia das famílias.

${ }^{59}$ A carta foi endereçada a Lévi-Strauss em 1999.
} 
Esta é a resposta do antropólogo: coerente com o que sua disciplina permite sustentar, sem posicionar-se de forma alarmista, normativa ou preditiva. Não seria isso também o que se esperaria de um psicanalista?

Parece que diante das grandes indagações que estas realidades têm suscitado na atualidade - novas configurações familiares, reprodução assistida, mudanças no campo da sexualidade - algo da pessoa do pesquisador/cientista (psicanalistas aí incluídos), que redunda em julgamentos morais, ou na assunção de opiniões pessoais, se impõe diante das demandas por um posicionamento. Esse posicionamento se traduz muitas vezes em uma indiscriminação entre convicções pessoais e leituras das práticas sociais e do funcionamento psíquico. É preciso que esteja definitivamente excluída para o psicanalista a possibilidade de se converter em um defensor dos costumes ou em um censor, mas também não pode deixar-se encantar com a "liberação" dos costumes, mesmo que pretendendo recusar a pecha de reacionário.

\section{3 - Época: um recorte específico na história}

A psicanálise tende a se instalar em um discurso a-histórico, localizando, de um lado a ordem subjetiva, intemporal e, de outro, a dimensão histórica das relações sociais. $\mathrm{O}$ discurso lacaniano, no entanto, não se caracteriza por ser intemporal, mas intempestivo! (CHEMAMA, 1997). O ensino de Lacan permite entrever que ele escutava atentamente o que se passava no social e, em mais de uma ocasião, enfatizou que o psicanalista não deve tomar o sujeito como separável da subjetividade de sua época ${ }^{60}$. O estudo das declinações do pai nos permitiu acompanhar como Lacan tomou essa prescrição ao pé da letra em seu ensino: a pluralização dos nomes do pai é uma decorrência de sua leitura constante e sensível do social.

Articular estrutura e história não é uma simples empreitada. Ao contrário, consiste em uma tarefa a ser executada com cuidado para não se cair em um emaranhado de autores, conceitos, posicionamentos e polêmicas dos quais resulta extremamente difícil extrair

\footnotetext{
60 "Que antes renuncie a isso, portanto, quem não conseguir alcançar em seu horizonte a subjetividade de sua época. Pois, como poderia fazer de seu ser o eixo da tantas vidas quem nada soubesse da dialética que o compromete com essas vidas num movimento simbólico. Que ele conheça bem a espiral a que o arrasta sua época na obra contínua de Babel, e que conheça sua função de intérprete na discórdia das línguas" (LACAN, 1953c, p. 322, grifo meu).
} 
um fio condutor. Que posição me permito compartilhar, de modo a habilitar uma leitura possível dos elementos que pretendo isolar neste trabalho? Procurarei investir nessa articulação de forma cuidadosa, mas não exaustiva, valendo-me do modo como Lacan sempre esteve atento, na tentativa de isolar o que é da ordem da estrutura, para também inscrever nesta a história do sujeito, submetendo-a à prova com a vivacidade da clínica, apelando à clínica para animá-la.

Para realizar tal tarefa, recorrerei a outros autores que retomam o texto de Lacan e lhe acrescentam novos alinhavos. O leitor verá que examinarei mais detidamente as formulações de Sidi Askofaré. Trata-se de uma escolha, já que elas me pareceram as mais passíveis de operar como um fio condutor. Minha proposta é tratar o tema de um modo possível, ou seja, como aquilo que cessa de se não se escrever, pelo menos por um momento, para que a pesquisa possa continuar.

A pergunta central que me faz adentrar este terreno e da qual não é possível furtar-me quando o que está em jogo é examinar um neologismo já surgido e cada vez mais consistente, é esta: como estrutura e história se articulam? Se se entende que o sujeito e o laço social não são entidades estanques, como pensar os efeitos na subjetividade dos modos de laço social predominantes de uma dada época?

É importante marcar que, historicamente, estrutura e história foram considerados conceitos inconciliáveis. Apesar das críticas a Lacan por deixar a segunda de lado (Cabral, 2006), vimos que ele propôs a escuta do psicanalista daquilo que prevalece no laço social na sua época. Lacan apontou também para o modo como isso se concretiza, seja no que concerne à função paterna, seja o Édipo: como operação que une a estrutura do sujeito à sua história singular. Podemos então afirmar - de forma um pouco rápida, concordo - que o modo pelo qual Lacan edifica o conceito de estrutura ${ }^{61}$ prevê que este possa articular-se ao de história.

A especificidade da estrutura em Lacan estaria no fato de esta ser marcada, "descompletada" pela contingência" (CABRAL, 2006, p. 132): "se a revolução pósestruturalista (o último Barthes, Derrida, Lacan) teve algum sentido, foi mostrar a

\footnotetext{
${ }^{61}$ Para um estudo mais aprofundado sobre o tema da estrutura, ver: MAFRA, T. M. (2000) A estrutura na obra lacaniana. Rio de Janeiro: Companhia de Freud.
} 
contingência das relações estruturais" (LACLAU, 2006, p. 112, tradução livre), algo que poderia ser formulado nestes termos: a estrutura é necessária, mas depende da contingência para inscrever-se, é ainda animada singularmente pelo sujeito. No seguinte trecho Lacan assinala a contingência das relações estruturais:

Por esse fato, a aparente necessidade da função fálica se descobre ser apenas contingência. É enquanto modo do contingente que ela pára de não se escrever. A contingência é aquilo no que se resume o que submete a relação sexual a ser, para o ser falante, apenas o regime do encontro (LACAN, 1972/73, p. 101).

Voltando à articulação entre estrutura e história, cabe perguntar: com que história opera a psicanálise? Cabral (2006), em um artigo com o sugestivo título de "Na cura analítica, proteger a história da História" ${ }^{2}$, se concentra na noção de história com a qual opera a psicanálise, defendendo Lacan das críticas recebidas por não levar em conta a história e destacando a história que Lacan "detestava". Sigamos o modo como o autor vai desenvolvendo sua reflexão.

Lacan marcava os limites de uma psicanálise sustentada exclusivamente na historização, uma vez que em seu tratamento da história não se operaria com o que não é historicizável, com o real. O risco seria recair em uma orientação da cura formulada em termos de tornar consciente o que é inconsciente. Cabral então parafraseia Lacan: "na cura analítica é possível, sim, prescindir da história [...] mas com a condição de ter-se servido previamente dela. Em outros termos, somente servindo-se do recurso à historização pode-se constituir o campo do não historicizável (p. 122, tradução livre).

Em Função e campo da fala e da linguagem em psicanálise, Lacan faz referência a uma “investigação histórica autêntica", marcada pelo esforço em seu ensino de precisar os pontos de inflexão que, na história da cultura, foram se produzindo no nível dos discursos, outro modo de referir-se a uma investigação sobre as articulações entre cada época e a estrutura. Cabral (2006) entende que Lacan oporia história e História, situando a "investigação histórica autêntica" do lado da primeira e a noção tradicional de história, sustentada em pretensas "leis da história", do lado da segunda. De acordo com o autor, seria essa a história que Lacan “detestava”. Uma história que seria muito mais tributária

\footnotetext{
62 Título original: En la cura analítica: proteger a la historia de la Historia.
} 
do que o investigador visaria corroborar do que dos acontecimentos históricos singulares; uma história que se sustentaria em um viés edificante, incorporado em sua vocação pedagógica, e que seria marcada por uma operação legitimadora.

A História "detestada" por Lacan, ainda segundo Cabral (2006) seria aquela que procura alinhavar uma sucessão de acontecimentos por meio de uma coerência imaginária, provendo sentidos, produzindo universais. Dessa forma, se inscreve na lógica própria ao discurso do mestre, promovendo significantes privilegiados, significantes mestres (aqueles que dão consistência e estabilidade para os fenômenos de massa). Seriam estes os significantes que ordenariam identificações como "membro de", e, em escala individual, "filho de". A investigação histórica autêntica, ao contrário, "[...] ao fragmentar no indivíduo o que se pensava unido e revelar marcas de heterogeneidade no que se supunha homogêneo, opera no sentido oposto" (CABRAL, 2006, p. 125, tradução livre, grifo meu).

Bem, se de fato o autor é preciso ao pontuar a especificidade da história com a qual opera a psicanálise, perde-se ao tratar a história em oposição à História e mesmo quando pretende circunscrever a tal História "destestada" por Lacan. E então penso no embaraço que o deparar com o título de seu artigo produziu em mim: "Na cura analítica, proteger a história da História" ${ }^{63}$. Haveria então uma boa história e uma má História? Do lado da primeira estaria o sujeito e a singularidade, do outro lado o indivíduo, o universal e o homogêneo? Seriam essas últimas categorias detestadas pela psicanálise? Estruturar-se-ia o lado bom (o sujeito) à parte do que se configura do lado da História (cada época e o que comparece ali como sintomático)? Seria então a estrutura impermeável aos acontecimentos históricos? Se o autor é claro ao destacar como a história comparece na psicanálise de orientação lacaniana, parece confundir a crítica que se faz aos dispositivos de controle implicados na História com a lógica do discurso do mestre na qual esta se inscreve, gerando enunciados - como "membro de", "filho de", conforme exemplifica Cabral - em relação aos quais o sujeito deve posicionar-se, estando sempre de alguma forma a eles referido.

É na cura analítica que reconhecemos um dispositivo genuíno de proteção da história (seguramente, não o único) no que esta contém, como veremos adiante, de empuxo a realização do próprio ser, frente

\footnotetext{
${ }^{63}$ Esta temática é importante para a discussão que será realizada no capítulo 4.
} 
à pressão uniformizadora da Historia do Outro (CABRAL, p. 125, tradução livre).

O autor lembra a escolha de Lacan pelo termo realização da história no lugar de reconstrução (que estaria referida a um objeto como pré-existente): "O que se realiza em minha história não é o passado simples daquilo que foi, uma vez que ele já não é, nem tampouco o perfeito composto do que tem sido naquilo que sou, mas o futuro anterior do que terei sido para aquilo em que me estou transformando" (LACAN, 1953c, p 301).

Ao pretender que na cura analítica se procede a uma realização da história, encontramos em Lacan os vestígios do pensamento freudiano. Em Recuerdo, repeticion y elaboracion, Freud propõe que o sofrimento do analisante não seja tratado como fato histórico, mas como uma potência atual. Pontua ainda, que o analisante não recorda nada do esquecido ou reprimido, mas o vive novamente.

Então, caberia à psicanálise proteger a história da História? Autorizaria a leitura de Lacan semelhante enunciado? Tomar a história como separada/separável da História? Mas isso não iria na contramão da recomendação - ou prescrição, que é o modo pelo qual a tomo - de Lacan no que diz respeito à abordagem de uma época? Tal enunciado, se aplicado ao contexto da presente pesquisa, levaria não só à oposição entre família e parentalidade, como à leitura de que se deve proteger a família daquela, perspectivas das quais pretendo me distanciar.

Askofaré (2009) apresenta uma interessante e coerente proposta de articulação, no campo psicanalítico, entre sujeito e história, partindo da constatação da dificuldade de se articularem estes elementos, mais especificamente de articular o "[...] sujeito à história como processo e como lugar das diferenças" (p.166). O autor pergunta: Pode-se falar de um sujeito contemporâneo - o que evoca uma especificidade ligada ao tempo, à época e, portanto, à história - se o sujeito se define pelo seu assujeitamento à linguagem, e como o que um significante representa para um outro significante?

O sujeito, para a psicanálise lacaniana, é o sujeito do significante. Ele é o efeito da linguagem, que é o que especifica o humano. "Progressivamente, o termo sujeito veio a designar, de uma só vez, o indivíduo empírico que se submete à experiência e à 
instância que se deduz da mesma experiência, instância suposta ao saber inconsciente, ao inconsciente como saber" (ASKOFARÉ, 2009, p. 166). Todo ser que é tomado na linguagem e que exerce a função da fala é um sujeito, ou seja, pode-se dizer que há o sujeito desde sempre e que haverá sempre o sujeito, enquanto houver linguagem, enquanto os homens continuarem a falar.

Há sujeito desde sempre, e o inconsciente do sujeito é o discurso do Outro ${ }^{64}$. Logo, se o Outro se vê afetado pelo contexto histórico, as marcas deste contexto incidirão sobre o sujeito. Penso ser preciso, por isso mesmo, que os encarregados das funções materna e paterna para a criança possam operar como um anteparo diante do que se apresenta como imperativo em uma época, interceptando o discurso prevalente na transmissão. A família como resíduo, desmembrada nas funções materna e paterna, opera a partir das versões pelas quais o gozo é singularizado em cada sujeito, e, neste caso, não é como pai ou mãe que eles comparecem, mas como sujeitos e os modos que arranjaram de fazer frente à inexistência da relação sexual.

Aliás, Lacan não diz outra coisa quando tenta situar, em 1953, o problema das relações do sujeito da fala e da linguagem. O que ele propõe são as coordenadas de uma verdadeira subjetividade, quer dizer, de uma forma histórica e determinada de traços, de posições e de valores que os sujeitos de uma época têm em comum, em suas relações com o Outro, como discurso; no presente caso, o discurso da ciência (ASKOFARÉ, 2009, p. 170).

Se o inconsciente é estrutura, é o lugar do Outro, há que se pensar que o Outro não se reduz aos pais:

[...] é o Outro do discurso universal que determina o inconsciente como transindividual. Ora, o Outro, entendido nesse sentido, ou seja, o simbólico, se ele é invariável em sua estrutura - aquela da linguagem -, é também submetido às mudanças, às mutações, às rupturas, às subversões (ASKOFARÉ, 2009, p. 169).

Isso é o que permite a Askofaré afirmar que o sujeito tem coordenadas históricas e culturais muito precisas.

\footnotetext{
64 "Que o inconsciente do sujeito é o discurso do Outro, eis o que aparece, ainda mais claramente do que em qualquer lugar, nos estudos que Freud consagrou ao que chama de telepatia, na media em que ela se manifesta no contexto de uma experiência analítica" (LACAN, 1953c, p. 266).
} 
O Outro, invariável em sua estrutura, sofre influências da história, sofre influências do que em uma época se apresenta como sintomático, como modo de sutura da falta prevalente. O discurso da ciência é o discurso prevalente nessa época. Veremos no capítulo 3 que ele é altamente sedutor quando apresenta aos pais certezas e soluções e promete aliviá-los dos riscos e das imperfeições inerentes às funções parentais.

No trecho reproduzido a seguir, é possível localizar o cuidado, preconizado por Lacan já em 1938, que se deve ter de compreender um sujeito na cultura em que este está inserido:

Com efeito, são as relações da psicologia do homem moderno com a família conjugal que se propõem ao estudo do psicanalista; esse homem é o único objeto que ele submeteu verdadeiramente à sua experiência, e se o psicanalista reencontra nele o reflexo psíquico das condições mais originais do homem, como pode pretender curá-lo de suas fraquezas psíquicas sem compreendê-lo na cultura que lhe impõe as mais elevadas exigências, sem compreender também sua própria posição perante esse homem no ponto extremo da atitude científica.

Ora, em nosso tempo, menos que nunca, o homem da cultura ocidental não poderia ser compreendido fora das antinomias que constituem suas relações com a natureza e com a sociedade: como, fora delas, compreender não só a angústia que ele exprime no sentimento de uma transgressão prometéica em relação às condições de sua vida, mas também as concepções mais elevadas com que vence essa angústia, reconhecendo que é através de crises dialéticas que ele se cria, a si mesmo e a seus objetos (LACAN, 1938, p. 54).

Conforme já foi destacado, em Os complexos familiares, Lacan não estabelece uma divisão clara e ordenadora entre estrutura e história, reconhecendo uma crise psicológica decorrente do declínio social da imago paterna. Entretanto, o percurso realizado até aqui pretendeu ser esclarecedor em relação à improcedência de se reconhecer no que veio depois, ou seja, nas declinações do pai em Lacan, a manutenção dessa confusão ou mesmo qualquer possibilidade de identificação da operacionalidade da função paterna com o lugar do pai na família ou na sociedade. Esse esclarecimento não visa concluir que a história não incide na subjetividade; ao contrário, a noção de pai Real e a pérèversion são já formulações inseridas em um determinado momento histórico, a partir de como Lacan se propôs a escutar o sujeito em sua época, o que, é central frisar, é diferente de assumir uma relação linear entre história e subjetividade. 
Um modo interessante de concluir esta discussão, mesmo antevendo que esse tema espinhoso deixará sempre um resto, é retomar o neologismo histoeria (hystoire) proposto por Lacan no "Prefácio à edição inglesa". Nele o autor condensa história e histeria (aliás, cabe comentar que em Lacan comparecem mais as condensações mantendo a tensão entre os termos em seus neologismos que as simples oposições), une história subjetiva - o sujeito, portanto - com histeria, estrutura que se particulariza por evidenciar a incidência do discurso do Outro sobre o sujeito. A história do sujeito não é sem o discurso do Outro!

\section{4 - Do mal-estar na civilização ao mal-estar na atualidade}

Vimos no início deste trabalho como Freud se surpreendeu com o fato de a cultura, apesar de ser uma produção humana, não representar nenhuma garantia de felicidade. Mais que isso, ao verificar que a cultura requer de seus indivíduos, necessariamente, uma perda de felicidade. Retomarei o texto freudiano sobre o mal-estar na civilização e o modo como localiza a perda que resulta do encontro do sujeito com a cultura com o intuito de situar o que vem sendo nomeado, nesta época, como mal-estar na atualidade. É no âmbito do mal-estar na atualidade que vemos surgir o termo "parentalidade", oferecendo-se como uma resposta da época ao que se lê - do lado do especialista da família - como um mal-estar parental, ou, conforme proponho neste trabalho, como um modo de sutura da falta prevalente no laço social, sustentado no discurso da ciência em sua determinação de forcluir o impossível da educação. Impossível localizado por Freud, aos quais acrescentou outros dois: governar e psicanalisar ${ }^{65}$. O impossível, furo, falta ou perda necessária, nomes possíveis do real, foi formalizado por Lacan nos termos de "não há relação sexual".

Em $O$ mal-estar na civilização Freud marca a contradição fundamental existente entre civilização e prazer, destacando o caráter deste buraco, que deve ser conservado, uma vez que ordena a dialética do desejo. O mal-estar, portanto, se particulariza de acordo com o que se apresenta como imperativo em cada época. É neste sentido que diversos autores (destaco Charles Melman, Jean-Pierre Lebrun, Joel Birman) vêm se dedicando a circunscrever e ler o modo pelo qual o mal-estar se particulariza neste momento histórico, ou, como é mais freqüente ser mencionado, o mal-estar na atualidade.

\footnotetext{
${ }^{65}$ C.f. - Análisis terminable e interminable (1937).
} 
Procurar responder à pergunta sobre como se configura o mal-estar na atualidade implica atravessar um emaranhado de autores, produções polêmicas e que algumas vezes denotam posições radicais a partir dos modos possíveis de serem lidos os efeitos da história na subjetividade, tanto na clínica como no laço social.

Não me proponho a examinar cada uma das várias maneiras pelas quais essa articulação é explorada, mas adianto que me distancio daqueles que assumem posições mais alarmistas em suas leituras sobre o mal-estar na atualidade. Tomo como referência os autores que, em suas análises, recorrem à letra de Lacan e que são prudentes nas consequiências que dela extraem, sem lamentar o tempo passado ou enaltecer o tempo presente.

Permanecerei um momento no texto de Freud de 1929, no tratamento que dá ao tema da felicidade, dado que esta se apresenta como um dos imperativos de nossa época. Para Freud, a aspiração humana pela felicidade teria duas faces: uma positiva e outra negativa; por um lado visaria evitar a dor e o desprazer, por outro, experimentar intensas sensações prazerosas. No sentido estrito, o termo "felicidade" só se aplicaria ao segundo fim. Nossa busca pela felicidade seria limitada pela nossa própria constituição; assim, a finalidade de evitar o sofrimento tende a relegar para segundo plano a de obter o prazer.

A complicada arquitetura de nosso aparelho psíquico coloca-nos diante da seguinte questão: a satisfação dos instintos (que implicaria a felicidade) se converte em causa de sofrimento quando o mundo exterior nos priva dela, negando a satisfação de nossas necessidades. Mesmo assim, com essa complicada arquitetura, nosso aparelho psíquico é capaz de adaptar suas funções ao mundo para tirar proveito deste na realização do prazer: "Assim como o comerciante prudente evita investir todo seu capital em uma só operação, a sabedoria talvez nos aconselhe não fazer depender toda a satisfação de uma única tendência [...]" (FREUD, 1929, p. 3030, tradução livre).

Então fica estabelecido o paradoxo: a cultura seria a grande responsável pela miséria que sofremos - civilização é mal-estar! Contudo, todos os recursos com os quais procuramos nos defender contra o sofrimento procedem precisamente da cultura (independentemente do sentido que se dê ao conceito de cultura, precisa Freud). O que é desconcertante na descoberta freudiana é que os homens não suportam a civilização, 
nem podem viver sem ela; devem estar juntos, separadamente (Rey-Flaud, 2002). Mesmo que o autor não faça uma referência direta, impossível não lembrar a parábola dos porcos espinhos relatada por Freud em Psicologia das Massas e análise do eu, dando consistência à formulação de que " [...] nenhum homem suporta uma aproximação demasiado íntima dos demais" (FREUD, 1920-21, p. 2583, tradução livre).

Faço aqui uma breve parada para comentar o filme "Onde vivem os monstros" a ilusão de estar juntos, em um mundo sem conflitos, comparece sob o desejo dos personagens de "dormir amontoados". Essa ilusão, como possível tratamento da falta, logo se revela insustentável, pois os furos não cessam de insistir. Contudo, se viver juntos é mal-estar, o filme mostra que as soluções de cada um diante do mal-estar são singulares e contingenciais.

O filme começa com um buraco que o garoto Max, de 10 anos, cavou na neve e que chama de Iglu. Dentro dele sente-se protegido, inventa brincadeiras, faz-de-conta que é um rei. Max vibra com uma guerra de bolas de neve que deflagra contra os amigos da irmã que, já moça, não liga mais para ele, não quer mais brincar. A guerra termina com a destruição de seu iglu. Max chora. A irmã vai embora com os amigos. O menino, em um acesso de raiva, destrói um presente que fizera para ela. Ele sofre, angustia-se, sente-se mal e culpado.

A mãe, quando chega, diz que, se estivesse em casa naquele momento, teria protegido o filho... Pouco depois, Max novamente se sente só, a irmã está crescendo, a mãe tem um novo amigo, e o menino não encontra parceria para partilhar o prazer intenso que experimenta nas suas brincadeiras. Em um acesso de fúria, acaba mordendo a mãe e foge.

Viaja por mares revoltos, luta contra ondas poderosas e finalmente atraca numa ilha. É lá onde vivem os monstros. Monstros que ameaçam devorá-lo, mas Max os convence de seus poderes. Podemos também pensar que os monstros querem ser convencidos, anseiam por alguém que faça essa promessa, que os iluda, que traga um sopro de esperança. E, bem, Max é muito bom nisso, tem um brilho no olhar e energia suficiente para mobilizar todo o grupo.

\footnotetext{
${ }^{66}$ Título original: Where the wild things are, direção de Spike Jonze, 2010.
} 
Os monstros consentem que Max seja o rei, um rei que poderá livrá-los da solidão, que promete mantê-los juntos, afastar a dor, os conflitos... Esses monstros parecem sofrer do mesmo mal que sofremos os humanos: para eles, estar juntos, apesar de inevitável, também é mal-estar!

Na primeira noite, Max e os monstros dormem amontoados. Max não está mais sozinho. Como rei, pretende reinar num mundo onde poderá manter todos juntos e protegidos e onde pretensamente os conflitos estarão do lado de fora.

O garoto vive os momentos de alegria sorvendo e saboreando cada instante. No filme, a trilha sonora e a fotografia contribuem para que saboreemos também a delícia desses momentos e que, assim como o monstro Carol, sonhemos com um mundo onde tudo é sempre bom e os conflitos possam ficar do lado de fora. Para Max e Carol, deparar-se com o que foge ao previsto nesse mundo idealizado é motivo para descontrole, desespero e sofrimento.

Max traz algo de novo para o grupo, uma promessa, uma utopia? Os monstros fingem acreditar nesse novo rei - e por isso não o devoram? - para desfrutar do frescor que a chegada deste jovem membro anuncia. Max acredita no tal mundo onde todos dormirão sempre amontoados... mas se angustia com cada sinal de que isso não será sempre possível.

Será que o que está em jogo para Max tem a ver com o sofrimento da criança? Sofrimento necessário e contingente à inscrição daquilo que não cessa de não se escrever na estrutura? Um sofrimento que pertence ao tempo da infância? Mas e Carol? Ele parece viver o mesmo conflito que Max e já é um monstro adulto.

Dar conta de que há sempre algo que escapa e se constituir como desejante, apesar disso, ou para além disso, ou ainda, fazendo o seu melhor com isso, é uma tarefa pela qual todos temos que passar e que passamos de diferentes maneiras. Os monstros do filme não são só bons ou maus, mas mostram diferentes formas de dar conta daquilo que escapa... 
O filme se desenrola sem menção à família de Max, ao lugar de onde vem. O garoto está incumbido de manter todos juntos, de construir este mundo no qual os males e os maus ficam de fora - a promessa inclui arrancar o cérebro daqueles que não são bemvindos - e encontra em Carol um alter ego. Com ele tem a relação mais próxima, mais intensa e se desdobra tentando garantir o que prometera ao amigo. Ele e Carol acreditam que isso será possível. Já os outros monstros... há uma que se mostra mais provocadora e cética, há outro que sempre soube que a promessa de Max era um engodo, mas queria ver Carol feliz e há ainda KW, que abandona o grupo quando a coisa aperta...

Max dedica-se a planejar esse mundo onde todos poderão sempre dormir amontoados, mas os pequenos conflitos começam a surgir: insatisfações, demandas não satisfeitas, provocações. Numa cena em que Carol está desesperado e violento, KW oferece proteção a Max, sugere que se esconda dentro de sua boca! A possibilidade de protegêlo vem atrelada à de literalmente devorá-lo.

Não à toa, é nesse momento que Max se lembra da mãe, daquela que teria protegido seu iglu, daquela que ele mordeu (mas não devorou) e abandonou. Proteger...devorar... consentir naquilo que escapa sem com isso se deixar devorar? Não consentir, mas viver abandonando o barco a cada vez que o mal-estar se impõe?

É também nessa cena e com esse monstro protetor (mas que, diante da falibilidade do rei, de todos os reis, pois Max foi o único que não devorou, foge, não fica para construir o que é possível), de dentro de sua barriga, que Max fala de sua família, compartilha como é difícil viver em família. É aqui que começa seu retorno para casa.

Diante do impossível, do real, daquilo que escapa, os monstros - até os monstros? reagem de formas diferentes, Carol torna-se violento e desesperado (como nosso pequeno Max), KW abandona o grupo, os outros monstros mostram-se céticos ou melancólicos.

Max retorna desta viagem diferente. Não porque descobriu onde vivem os monstros, e agora pode deixá-los, mas talvez porque tenha descoberto que os monstros estão sempre à espreita e possa agora construir o seu modo particular de lidar com o fato de que nem sempre dormiremos todos amontoados. 
Voltemos a Freud e à busca da felicidade. Refletindo ainda sobre as maneiras pelas quais o homem se esforça para obter a felicidade e distanciar-se do sofrimento, Freud situa o "amor" e pontua: jamais nos encontramos tão à mercê do sofrimento como quando amamos. Entretanto, a linguagem que emprega para o termo "amor" é imprecisa. Pode estar se referindo à relação entre homem e mulher (que fundaram sua família sobre a base de suas necessidades genitais), mas também se denominam "amor" os sentimentos positivos entre pais e filhos, entre irmãos e irmãs, mesmo que estes

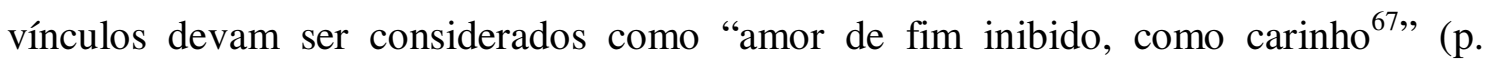
3041). Se o amor genital leva à formação de novas famílias, o fim inibido leva à amizade, que tem valor na cultura, pois escapa a muitas restrições do amor genital, como, por exemplo, a seu caráter exclusivo. "Contudo, a relação entre o amor e a cultura deixa de ser unívoca no curso da evolução: por um lado, o primeiro se opõe aos interesses da segunda, que por sua vez o ameaça com sensíveis restrições" (FREUD, 1929, p. 3041, tradução livre).

Para Freud, esse divórcio entre amor e cultura começa a estabelecer-se como um conflito entre a família e a comunidade social mais ampla. "Quanto mais íntimos sejam os vínculos entre os membros de uma família, tanto maior será muitas vezes sua inclinação a isolar-se dos demais, tanto mais difícil lhes resultará ingressar nas esferas sociais mais vastas" (1929, p. 3041, tradução livre) Aqui pareceria que Freud refere-se mais a uma resistência por parte da criança às renuncias necessárias ao empreendimento cultural do que ao fato de a família resistir a ingressar na esfera cultural. Tanto é que, na sequência, o autor ressalta a importância que alguns ritos de puberdade e iniciação têm para o adolescente. Até porque, se pensamos na família como célula mínima da sociedade, sua função é justamente dar condições para o ingresso do novo indivíduo na cultura. É nesse sentido que Hannah Arendt (2003), em "Crise na educação”, atribui aos adultos (que já estão por aqui há mais tempo) a tarefa de introduzir a criança no mundo que é novo para ela; ou que Winnicott (2001), em "Família e maturação emocional" atribui à família a função de propiciar as condições para a participação de seus

${ }^{67}$ Remeto o leitor ao texto de Pommier intitulado "O desejo 'de' criança (...e seu avatar pedófilo)" In: Revista Literal - Escola de Psicanálise de Campinas. Volume 11 - sexualidade e(m) diferença. Campinas, 2008, pp. 117-127. O autor parte do equívoco inerente à expressão "desejo de criança" (desejo de ter uma criança e desejo sexual por uma criança) tomando essas perspectivas como não antinômicas, ainda que seja crucial que este segundo viés sofra a ação do recalque. Desse modo, é possível resguardar o lugar da dimensão sexual na transmissão familiar em uma época em que se pretende elidi-la sob o risco de ser apreendida como uma forma de abuso. 
indivíduos na sociedade mais ampla. É por isso que se pode dizer que não existe corte entre o campo social e a cena familiar, o que se passa na vida social influencia a vida familiar. Em outras palavras, a família reproduz em seu seio o limite ao gozo que a civilização cobra de seus integrantes. Decorre daí que o que comparece no campo social como mal-estar na atualidade não é sem conseqüências para as relações que se organizam no âmbito familiar.

Freud conclui: se a cultura nos impõe tão grandes sacrifícios, não apenas à sexualidade, como também a nossos instintos agressivos, podemos compreender melhor por que é tão difícil para o homem alcançar a felicidade.

Ao propor a sua leitura do mal-estar na atualidade, Birman (2005) situa que o mal-estar formalizado por Freud era já um mal-estar na modernidade. Lembra que em "Moral sexual civilizada e doença moderna", texto de 1908, Freud ainda apostava em uma harmonia entre o sujeito e o social, e localiza as perspectivas terapêuticas que investem na harmonia do sujeito com o campo social e a medicalização do social como um retrocesso, dando corpo a uma psicanálise normativa, não condizente com a leitura crítica de Freud sobre a modernidade, fundada no sujeito e seus impasses.

Se a psicanálise deixa claro que a desarmonia está na base da relação do sujeito com a cultura, nem por isso aquele deixa de demandar a cura para seu mal-estar e seu desamparo.

A ilusão continua lá, intacta, nos corações e mentes dos indivíduos. Por isso mesmo, a psicofarmacologia, as neurociências e o cognitivismo vêm à cena para restabelecer a mesma crença e ilusão das subjetividades de que tudo ainda seria possível. Esses saberes, com suas tecnologias específicas, vêm ao mundo para fazer a mesma promessa e alimentar a mesma ilusão de harmonia possível, como acreditava ainda o primeiro Freud (BIRMAN, 2005, p. 144).

A ilusão de harmonia, e mesmo a demanda que ela gera, é legítima. Já em 1927, Freud assinalava que o homem não poderia renunciar às ilusões uma vez que elas são necessárias para se tolerar a vida. As ilusões são imperativas para se tolerar a condição 
humana, logo não se pode prescindir delas ${ }^{68}$. Para operar, o discurso social conta com a ilusão, velando a verdade da desarmonia que nos é estrutural, e tornando, dessa maneira, a vida tolerável. Nessa linha, "uma ilusão não é o mesmo que um erro nem é necessariamente um erro" (FREUD, 1927, p. 2977, tradução livre), prescinde de toda garantia, afirma Freud, outro modo de dizer que a ilusão opera como um semblante. O que se critica são os discursos que prometem garantir essa harmonia, "[...] sem sequer preocupar-se mais em saber se é ou não semblante" (LACAN, 1971, p. 27). Veremos a seguir que o discurso científico aspira a elidir sua própria dimensão de semblante ao identificar-se com a verdade e pretender excluir o real.

Freud se ocupou do tema da ilusão em El porvenir de una ilusion (1927) propondo que as representações religiosas nascem da mesma fonte que as outras conquistas da cultura: da prepotência sobre a natureza e também do impulso de corrigir as imperfeições da civilização. Diante do desamparo da infância individual e da infância da humanidade, as ilusões constituem-se em representações que tornam tolerável o desamparo. E Freud propõe uma definição das representações religiosas, ou seja, uma definição de ilusão: "princípios e afirmações sobre fatos e relações da realidade exterior (ou interior) nos quais se sustenta algo que não pudemos encontrar por nós mesmos e que aspiram a ser aceitos como verdadeiros." (FREUD, 1927, p. 2973, tradução livre).

Nesse texto, Freud já detecta que a religião perde influência para o discurso cientifico, ainda que avalie que este último não encontrara ainda, na época, respostas para muitas de suas indagações. A substituição de um sistema de doutrinas por outro, diz ele, implica que se proceda com a mesma rigidez e intolerância; ou seja, o discurso científico, para prevalecer, precisa valer-se das mesmas condições nas quais se firmou o discurso religioso. Ao concluir que as doutrinas religiosas não são mais que ilusões, Freud passa a se perguntar se não o seriam outros fatores de nossa cultura, e localiza a ilusão na base da relação entre os sexos (perturbada por uma série de ilusões eróticas). Deduzo daí que a ilusão, dessa forma, está na base da relação entre os sexos, velando a inexistência da relação sexual.

\footnotetext{
${ }^{68}$ Não foi à toa Freud teve de renunciar à ideia de que, ao se esclarecer às crianças a sexualidade, avançaria em direção à diminuição das neuroses, já que verificou que elas não abandonam tão facilmente as suas próprias teorias - suas ilusões - que manteriam a verdade como velada - ou como mais tolerável.
} 
Bem, a ilusão, afixada na base do mal-estar que é a cultura prevalece como recurso para tornar tolerável a condição humana. Então o que se modifica em cada época é o modo de fazer frente ao mal-estar que a ilusão pretender encobrir? Essa questão é central diante de autores (especialmente Charles Melman, em Um homem sem gravidade, e de forma menos radical Jean-Pierre Lebrun em A perversão comum) que detectam no indivíduo contemporâneo a pretensão de livrar-se da perda de gozo que a vida na comunidade exige, ou, que a linguagem cobra, o que torna a ilusão prescindível.

Reproduzo a seguir a excelente formulação de Pujó acerca do modo como se articulam ilusão e contexto histórico, com a qual concordo essencialmente, porque marca a insistência com a qual se pretende contornar a castração inevitável, mas não pressupõe um indivíduo que se acredita realmente capaz de prescindir das ilusões:

Podemos então pensar que as formas de ilusão que predominam em um determinado contexto histórico, constituindo um modo culturalmente ativo a serviço de renegar a perda de gozo natural, que em última instância, denominamos castração, representa um modo de pensar a época inspirado na descoberta freudiana, encontrando cada época o modo de resolver-se em seu limite para renovar-se sob a forma de uma nova ilusão (PUJÓ, 2006, p. 64, tradução livre).

Esse pequeno trecho também habilita uma resposta afirmativa à pergunta formulada acima: cada época se renova sob a forma de uma nova ilusão. Então, o que se designa como mal-estar na atualidade é o tratamento dado contemporaneamente ao mal-estar na civilização. Destaco que tais afirmações inscrevem a atualidade como uma época a mais na História, com particularidades, é evidente, mas referida ao cenário estrutural do malestar na civilização e das ilusões necessárias para tolerá-lo.

Ao longo deste trabalho, ressaltei algumas vezes um aspecto que está na letra de Lacan e que serve como um vetor à investigação que ora proponho, que é o psicanalista sentirse convocado a estar à altura de sua época. Encontrei em Rey-Flaud (2002) a leitura de que o princípio que sustenta $O$ mal-estar na civilização (já perceptível em Totem e Tabu e em Psicologia das massas e análise do eu) consiste em que o destino do indivíduo não pode ser estudado fora do da comunidade na qual ele se insere. Há diferenças importantes entre o momento histórico em que Freud escreveu $O$ mal-estar na 
civilização e o momento histórico em que Lacan propôs uma leitura desse mesmo malestar.

O social em que Freud imergia era o da Primeira Guerra Mundial e do entre-guerras, enquanto Lacan fazia sua leitura diante de uma sociedade pós-Hiroshima e Auschwitz; “[...] se o primeiro podia compartilhar sem desconfiança o movimento cientificista de seu tempo, o segundo não podia desconhecer as devastações produzidas pela civilização tecnocientífica" (LEBRUN, 2004, p. 18). E o autor se pergunta: trata-se do mesmo malestar? (Questão que parece perder o sentido quando observa que a formulação de Lacan sobre os efeitos do discurso da ciência no mal-estar na civilização deve-se mais ao remanejamento operado por ele da descoberta de Freud do que a uma nova conjuntura histórica, ou seja, trata-se do mesmo mal-estar, o que varia são as formas históricoculturais de contorná-lo.)

Se Freud se ocupava da perda de felicidade inerente à vida em comunidade, atualmente essa demanda comparece como um empuxo a gozar (LAURENT, 2007), no apelo insistente e sedutor que o discurso capitalista, aspirando elidir a categoria do impossível, reafirma cotidianamente aos indivíduos, ao empanturrá-los gadgets. Nesse sentido, a felicidade comparece como um imperativo no campo coletivo e na família. Há aqui um paradoxo: o mal-estar estrutural, que intrigou Freud, se encontra no fato de que a cultura requer uma perda de gozo, mas a época atual - condensada no discurso capitalista - espera vender-nos a ilusão de que não há limites para o gozo, oferecendo objetos que tamponariam o menor indício de falta.

Uma interessante análise do modo como o imperativo de felicidade comparece na contemporaneidade é realizada por Brodski (2008), ao localizar o momento histórico em que o empuxo à felicidade tornou-se universal (a partir da Revolução Francesa), consolidando-se na busca de felicidade para todos e produzindo um achatamento do singular no universal. "É, precisamente, a partir do momento em que a felicidade passa do âmbito privado ao âmbito público, e que o público aspira manejar os corpos, que esse mesmo discurso produz um resto" (p.25) O imperativo de felicidade "para todos" produz um resto que não se encaixa. A psicanalista reconhece na depressão uma objeção ao universal e lembra que a maneira de a psicanálise tratar o real não se dá pelo universal, mas, ao contrário, pelo mais singular de cada um. 
Esse tema me interessa particularmente, pois veremos no próximo capítulo que os discursos e as políticas de apoio à parentalidade também assumiram esse traço do "para todos". Então, qual seria o resto produzido ao "para todos" do apoio à parentalidade? Se a depressão faz objeção ao universal contido no imperativo de felicidade, como localizaríamos o que faz objeção ao universal e ao homogêneo condensado no "para todos" da parentalidade?

Se na atualidade vivemos sob a égide dos discursos capitalista e científico, cabe perguntar o que pretende cada um deles. O que pretende o capital? Suturar a falta pela via dos objetos, prometendo satisfação imediata e livre de angústias. E que pretende o discurso científico? A ciência sutura o sujeito, despreza-o de seu campo. Pretende prevalecer sobre o real, encobrir a falta. Ambos aspiram a eliminar a falta, ambos incidem sobre a família e sobre a infância e acenam com possibilidades bastante tentadoras! O capital, aliado à ciência, promete construir uma sociedade sem sintoma. $\mathrm{O}$ conhecimento reunido pela ciência, transformado em uma técnica, ou seja, sem nenhum rastro de enunciação, converte-se em um bem, em um capital. É dessa maneira que os discursos científico e capitalista se aliam, o primeiro consistindo em uma ferramenta para o segundo, consolidando conhecimento para a realização de avaliações e habilitando avaliadores; o segundo utilizando-o como bem econômico a serviço de multiplicar o capital. Subjugados a esses discursos, os indivíduos acabam consentindo em converter-se em avaliadores e usuários.

As tecnociências ${ }^{69}$, versão do discurso da ciência liberada de qualquer vestígio de enunciação, têm efeito na relação entre saber e conhecimento, aspecto central no campo da subjetividade e da transmissão parental. O saber é reduzido ao conhecimento e o sujeito e a responsabilidade por seus atos são eliminados. Nesse sentido, a psicanálise, como retorno do sujeito excluído da ciência, converte-se em um sintoma, sintoma do real, e pode oferecer-se como uma segunda oportunidade (BASSOLS, 2007).

${ }^{69}$ Lebrun (2004) marca uma importante diferença entre o discurso do homem de ciência, o discurso científico, e o discurso técnico. No primeiro, a enunciação ainda está presente, no segundo há já o apagamento da enunciação e mantém-se apenas a autoridade dos enunciados. No discurso técnico - que é disponibilizado aos pais quando se pretende ensinar-lhes por meio de aulas a educar seus filhos - lidamos apenas com enunciados, sem qualquer vestígio da enunciação, que, contudo, inaugurou a sequência destes discursos. 
Birman (2005) surpreende-se com a insistência com que a pergunta "o que devo fazer?" tem sido feita ao analista. $\mathrm{O}$ autor marca que tal interpelação não é inédita, mas se impõe na atualidade com maior freqüência. Talvez o que não seja da mesma natureza que antes é a resposta do analista. Para o autor, isso significa que os destinos da interpelação em pauta não foram necessariamente os mesmos para o sujeito. Pergunta: como devemos tomar isso? O que se pode escutar nessa formulação desesperada? $\mathrm{O}$ autor lê aqui um convite da figura do analisando para a ação da figura do analista. Tratase de averiguar a natureza da demanda para verificar o que está em jogo na interpelação. Nas instituições educacionais e na clínica com crianças, tal interpelação também comparece, do lado dos pais, sob a forma de "isso é normal?" ou "o que devo fazer?". Penso que a psicanálise faz resistência aos outros discursos ao singularizar esta demanda, diante de uma tendência a homogeneizá-la e tratá-la com respostas universais e prêt-à-porter. Destaco a produção teórica e a atuação profissional de dois psicanalistas, Françoise Dolto e Donald Winnicott, que, apesar das diferenças em seus referenciais teóricos, cuidaram insistentemente para que os pais fossem escutados - na clínica, na instituição e até mesmo em programas de rádio - procurando conduzi-los a produzir e implementar suas próprias soluções, conforme veremos no próximo capítulo.

Um exemplo da homogeneização da demanda e da intervenção do especialista munido pelo discurso da ciência no âmbito familiar, é a "Escola para pais" ${ }^{\text {"70 }}$. O especialista da família, ao convocar os pais a um retorno à escola, transmitindo-lhes seus conhecimentos específicos sobre a criança, institui o discurso da ciência no lugar da transmissão. No lugar do saber inconsciente, da implicação, da angústia e dos riscos implicados no ato educativo, impõe-se um discurso totalizante, sem brechas, sem exceções, sem vazio, confirmando a formulação de Lacan sobre a criança generalizada.

Outra característica de nossa época é o discurso democrático e suas incidências não só no espaço coletivo mas também no âmbito da família. Lembremo-nos da "família democrática", descrita por Gavarini (2008), e de suas características: é regida pelo

\footnotetext{
${ }^{70}$ Vale esclarecer que me refiro às propostas como a citada na introdução desta pesquisa ou, ainda, a criação (na França) de um programa dirigido aos pais, trabalhadores sociais e associações que atuam na área da infância sob a forma de um Cd-rom intitulado "ser pais hoje em dia". Ele se propõe a "fortalecer as competências" das famílias com crianças de 7 a 16 anos (PLANTET, 2004). Tais propostas se inscrevem em outro marco político ideológico que as "Escolas para pais", idealizadas na França na década de 70 .
} 
princípio de igualdade entre seus membros e as tarefas e os papéis são autodefinidos por todos.

Freud, em Aclaraciones, aplicaciones y observaciones (1932 [1933]), atribui à educação a tarefa de levar a criança a aprender a dominar seus instintos, mas destaca que ela deve buscar seu caminho entre a permissão e a proibição. Acredita que é possível encontrá-lo produzindo para a criança o máximo de benefícios e causando-lhe o mínimo de danos (uma solução exitosa do ponto de vista econômico!). Voltolini ${ }^{71}$ traduz da seguinte maneira o que seria o ideal da educação para Freud: "desejar coisas para os filhos, tolerar suas escolhas". Assim sendo, modo encontramos já em Freud essa clareza: a educação sustenta-se em marcas de desejo, marcas que não são garantias. Marcas que implicam um arriscar-se para além do "para o seu bem" ou "porque era meu dever", marcas de desejo. $\mathrm{Na}$ atualidade, esse "arriscar-se" inclui também ousar para além das predições, medições e avaliações veiculadas pelo discurso científico.

Constato um dos efeitos do modo como o discurso democrático se insere na contemporaneidade no exercício das funções parentais quando os pais são categóricos sustentando o ato educativo numa promessa: "não vou desejar nada para meu filho, ele será o que quiser..." Nesse caso, a perspectiva pretensamente "democrática" institui a dimensão de promessa e se impõe em detrimento da proibição necessária e estruturante.

Em "Três conselhos para a educação das crianças", Calligaris (1994) alerta para a ocorrência de uma inversão entre promessa e dever ao se seduzir a criança "com uma promessa que compromete o valor de nossa palavra educadora" (p.28). O autor chama a atenção para o fato de que a hegemonia da condição de promessa imposta à criança compromete a dimensão simbólica. É certo que a educação se sustenta numa promessa: marcar o filho com o desejo; porém, sob vestes democráticas parece veicular-se um discurso autoritário. No imperativo de felicidade imposto às crianças, parece não haver lugar para o sujeito do desejo.

Assim, encontramos, por um lado, a idéia subjacente de uma transmissão asséptica no modo como a ciência atravessa o laço social na modernidade, por outro, no estabelecimento da liberdade de escolha - no modo pelo qual a democracia se instala no

\footnotetext{
${ }^{71}$ Em comunicação pessoal realizada em aula na pós-graduação da Faculdade de Educação da USP.
} 
laço social na modernidade - institui-se a criança como promessa (promessa de felicidade) para além do dever. $\mathrm{O}$ imperativo de felicidade parece atualizar-se no âmbito da família como uma promessa de eliminar para os pais o risco "de suas próprias faltas" e imperfeições.

Notadamente o neologismo parentalidade vem ganhando consistência na atualidade, condensando o modo como o mal-estar na atualidade se particulariza na família. Nesse sentido, pode ser traduzido como o sintomático desta época? Pode-se dizer que a parentalidade consiste em um modo de sutura da falta, característico desta época, diante do impossível da educação? Os discursos sobre a parentalidade, ao sustentar-se em noções como "competência parental", esperando convencer os pais da possibilidade de uma transmissão sem faltas ou imperfeições, representaria um risco para a família? Essas e outras questões que envolvem o neologismo parentalidade, suas origens e os discursos que lhe são subjacentes serão abordadas no próximo capítulo. 


\section{Capítulo 3 - Parentalidade: um neologismo que ganha consistência na atualidade}

"Rien d'éttonant alors à ce que de touts parts émerge le sentiment d'avoir à préserver le lien parental ${ }^{72} \gg$ (NEYRAND, 2006, p. 120).

O termo "parentalidade" se institui no vácuo da discussão sobre o declínio da função paterna e evidencia, no mesmo movimento que o forja, um mal-estar relativo ao desempenho das funções parentais. Apesar das boas intenções ${ }^{73}$ nas quais encontra suas origens, o novo termo é indissociável do mal-estar que lhe é suposto.

Ainda que não pretenda apresentar um histórico exaustivo ou realizar uma análise sociológica da origem do neologismo parentalidade, parece inevitável situar o contexto no qual ele tem sido progressivamente imposto, a fim de tirar minhas próprias conclusões acerca de seus efeitos e implicações no que se refere à família.

De acordo com o interlocutor, profissional ou universitário, o discurso sobre a emergência da noção de parentalidade é diferente (Fablet, 2008). Martin (2006b) propõe três argumentos para explicar por que se fala em parentalidade:

1 - A parentalidade como um meio de nomear o parent ou aquele que ocupa o lugar

2 - A parentalidade como um meio de dar conta das transformações no campo da família

3 - A parentalidade como um meio de desenvolver um discurso de ordem pública ${ }^{74}$

\footnotetext{
72 "Nada surpreendente então que de todas as partes emerja o sentimento de ter que preservar o laço parental" (tradução livre).

${ }^{73}$ No seminário A ética da psicanálise, Lacan adverte sobre os riscos de se fazer o bem: "Poder-se-ia de maneira paradoxal, ou até mesmo decisiva, designar nosso desejo como um não-desejo de curar. Essa expressão tem o sentido de alertar aos psicanalistas contra as vias vulgares do bem, tal como elas se oferecem a nós, contra a falcatrua de querer o bem-do-sujeito" (LACAN, 1959/60, p. 267).

${ }^{74}$ Embora o autor contextualize esse discurso nas principais dificuldades enfrentadas pelo poder público na França, onde a temática da insegurança/violência está na ordem do dia, avalio que o argumento pode ser ampliado a outros contextos.
} 
A seguir abordarei os discursos prevalentes em cada um desses argumentos, embora saiba que os outros discursos comparecem de forma mais ou menos explícita em cada um dos eixos e que não só os discursos como também os argumentos organizados por Martin se influenciam mutuamente. Abordar cada uma das dimensões separadamente, além de organizar a exposição a seguir, permite situar com mais clareza os aspectos que a meu ver merecem uma discussão mais aprofundada, assim como aqueles em relação aos quais mantenho uma posição crítica.

\section{1 - A parentalidade como um meio de nomear o parent $^{75}$ ou aquele que ocupa o lugar}

O neologismo parentalidade, agrupando os papéis e as funções parentais, surgiu na França na década de 80 (HOUZEL, 2004, SOLIS-PONTON, 2004). Iniciativas do poder público daquele país visando apoiar a parentalidade foram concebidas no fim dos anos 80 (PIOLI, 2006) e a intensificação do uso do termo parentalidade ocorreu em meados dos anos 90 (HOUZEL, 2004, FABLET, 2008, MARTIM, 2006a e 2006b). Paralelamente, ocorreu o fortalecimento das políticas de apoio e a implementação de discursos relativos à parentalidade em outros países, entre eles o Brasil, nos campos jurídico, sociológico, psicológico, e nos meios profissionais voltados à primeira infância (MARTIM, 2006a e 2006b, GAVARINI, 2006 e 2008, NEYRAND, 2006, GIAMPINO, 2006).

Em 1961, o psicanalista francês Paul-Claude Racamier introduziu o termo maternalidade para definir o “[...] conjunto dos processos psicoafetivos que se desenvolvem e se integram na mulher por ocasião da maternidade" (RACAMIER, 1961, apud HOUZEL, 2004, p. 47), propondo-o como tradução mais adequada do inglês motherhood $^{76}$, tradicionalmente traduzido como maternidade. Na sequência, Racamier acrescentou os termos paternalidade e parentalidade, sem especificar, entretanto, a que se referia. $\mathrm{O}$ objeto de estudo de Racamier e dos pesquisadores de seu grupo era a psicose puerperal. Assim, a origem dos termos maternalidade, paternalidade e, finalmente, parentalidade, estaria no que Houzel (2004) avalia como uma das patologias

\footnotetext{
75 Optei por manter o termo parent no original para evitar os riscos resultantes de uma tradução equivocada. Parents refere-se a pais, a pai ou a mãe; refere-se também àqueles que compõem os ascendentes de uma pessoa e, ainda, parent é qualquer pessoa com a qual se tenha um laço de parentesco. 76 De acordo com Martin (2006b) o termo parentalidade é uma tradução do termo anglo-saxão parenthood, que designaria melhor as funções parentais que o termo parentesco.
} 
psiquiátricas mais severas da parentalidade, concluindo que, "sem dúvida, não é por acaso que esse conceito apareceu nesta ocasião" (p. 47). O autor não justifica tal afirmação, embora pareça encontrar certa lógica no fato de que o termo parentalidade tenha sido forjado a partir do estudo de uma patologia situada do lado dos pais.

Houzel (2004) observa que não basta ser genitor nem ser designado como pai (ou mãe), é preciso "tornar-se pai” ou "tornar-se mãe", o que implica um processo envolvendo aspectos conscientes e inconscientes. Essa definição permite inscrevê-lo entre os autores com uma perspectiva psicológica em relação às figuras parentais, definindo a parentalidade como os remanejamentos psíquicos e afetivos que permitem ao adulto tornar-se pai (ou mãe), ou seja, responder às necessidades de sua criança em três níveis: o corpo, a vida afetiva e a vida psíquica.

Solis-Ponton (2004) define parentalidade como o estudo dos vínculos de parentesco e dos processos psicológicos que se desenvolvem a partir deles. "A parentalidade necessita de um processo de preparação, até de aprendizagem, não no sentido de pedagogia parental, mas como trabalho que põe em evidência a complexidade e as características paradoxais do fenômeno natural do parentesco" (p. 29, grifo meu). Chama a atenção que a autora atribua o adjetivo "natural" ao parentesco, dado que isso contraria as bases das estruturas elementares de parentesco estudadas por Lévi-Strauss, como vimos no capítulo 1. Ainda assim, vale destacar sua preocupação da autora em diferenciar o processo que descreve como parentalização de uma pedagogia parental, ainda que essa formulação pareça comportar uma perspectiva desenvolvimentista.

Sustentada na expressão de Lebovici de que "o bebê faz seus pais" e que, portanto, os pais nascem junto com a criança, Solis-Ponton propõe que o bebê parentaliza os pais. A construção da parentalidade, nesse sentido, é fundamental para a vida mental da criança. Em entrevista concedida à psicanalista, Lebovici pontua que optou pelo termo parentalidade no lugar de família, buscando não reduzi-lo ao fenômeno biológico, e entendendo que "[...] ser pai e ser mãe não é só ter um filho, mas também uma oportunidade para refletir a respeito de sua descendência" (2004b, p. 21). A parentalidade se constituiria, nessa perspectiva, a partir da aceitação de que herdamos algo de nossos pais. 
Nessa abordagem, justifica-se a inclusão do termo parentalidade no lugar do termo família porque o primeiro se destacaria como não decorrente do acontecimento biológico. Conforme vimos no capítulo 1, Lacan, já em 1938, investiu em isolar a família do fato biológico, e a articulação da família como resíduo de nenhuma maneira prevê que as funções materna e paterna sejam determinadas por laços biológicos ou dependam destes.

Tort (2008) destaca que, com a noção de parentalidade, surge uma definição de pais que não é dedutível nem da biologia nem do ser social, mas das qualidades das relações psíquicas com a criança. Esse me parece um modo muito interessante de recortar a especificidade das funções parentais, ainda que não justifique, a meu ver, a insuficiência do termo parentesco para alocar essas relações.

As investigações realizadas em torno da parentalidade e das importantes decorrências desse processo para o bebê vêm ocorrendo no âmbito de pesquisas sobre a primeira infância e sobre as competências do bebê, em um movimento que vai da criança como sujeito aos direitos da criança ${ }^{77}$ (NEYRAND, 2006). Outra vertente de pesquisas tem se dirigido ao tema da prevenção ${ }^{78}$, contudo, um viés importante desta vem adquirindo um caráter preditivo, justificando práticas de avaliação e controle e um considerável movimento de resistência ${ }^{79}$ entre os profissionais implicados no acolhimento institucional à primeira infância. Como vimos no capítulo 2, essa é uma das maneiras pelas quais o discurso da ciência se apresenta na atualidade, excluindo o sujeito, reduzindo-o à categoria de usuário e a números expressos em tabelas estatísticas, e autorizando intervenções de caráter avaliativo, normativo e homogeneizante.

Um último aspecto a assinalar é que a vertente psicológica do termo parentalidade não se dá sem conseqüências para o modo como os outros discursos aspiram a se apropriar dele, sobretudo no que diz respeito às políticas públicas que se organizam visando o apoio à parentalidade.

\footnotetext{
${ }^{77}$ Gavarini (2008) faz um interessante percurso dos direitos da criança ao direito à criança.

${ }^{78}$ Abordei esse tema em outra publicação: Clínica psicanalítica com bebês: uma intervenção a tempo. São Paulo: Casa do Psicólogo, 2005.

${ }^{79}$ Para maiores informações ver o manifesto "Les lieux d'accueil enfants-parents manifestent pour l'enfant", disponível no endereço eletrônico: http://www.pasde0deconduite.org/IMG/pdf/lieux_accueil_parents_enfants_manifeste-2.pdf.
} 


\section{2 - A parentalidade como um meio de dar conta das transformações no campo da}

família

A partir do que foi discutido no capítulo 2, acredito que é possível vislumbrar como o termo parentalidade vem ao encontro das novas configurações familiares. Contudo, será necessário que nos detenhamos em seus aspectos sociológicos e, sobretudo, no modo como na atualidade o discurso jurídico comparece e vem sendo pressionado a comparecer no âmbito da família e da proteção à infância.

A década de 70 foi decisiva no que diz respeito às mudanças jurídicas no âmbito da família: a expressão "chefe de família" foi suprimida, e o significante "parental" (conforme vimos no capítulo 2), originário do discurso jurídico, marcou a substituição da autoridade paterna pela autoridade parental. A família, nessa passagem, tornou-se "co-parental". Contudo, as mudanças mais cruciais (decorrentes das reivindicações das famílias homoparentais e dos avanços da procriação medicamente assistida) ainda estavam por vir, mudanças que vêm reverberando na área jurídica pressionando-a a legalizar e reconhecer laços anteriormente inexistentes, a reconhecer a suposta insuficiência da categoria do parentesco para dar conta das relações familiares instituídas e a concretizar os laços familiares sob o desígnio do termo "parentalidade".

Mas permaneçamos ainda um momento na década de 70. A lei do divórcio foi modificada em 1975, na França, pela introdução do "consentimento mútuo". Este substituiu a noção de "erro" ou "falta conjugal" que prevalecera até então (ROUDINESCO, 2003) prevendo que o genitor responsável pela separação matrimonial, devido às faltas que cometera, não deveria ser o detentor da guarda dos filhos. $\mathrm{O}$ abandono desse critério levou à dissociação entre os papéis de cônjuge e de pai ou mãe. Assim, o princípio da co-parentalidade está no interesse da criança de ser educada pelo pai e pela mãe, mesmo que eles sejam separados.

No Brasil, a legislação relaciona ainda a noção de culpa, falta grave que resulta na separação matrimonial, ao cuidado dos filhos; a noção de interesse da criança não substituiu a noção de falta conjugal, ou seja, convivemos com as noções de falta conjugal, interesse da criança e direitos da criança (BRITO, 2004). A lei do divórcio, eliminando a desigualdade entre homens e mulheres, data de 1977. 
Nos últimos anos, o número de divórcios não parou de crescer $^{80}$, concomitantemente à queda do número de casamentos; entretanto, nem por isso deixou-se de ter filhos ${ }^{81}$, configurando a disjunção entre conjugalidade e parentalidade, como vimos no capítulo 2. A preocupação em torno das crianças nos casos de divórcio teve como efeito a separação definitiva entre esses dois fenômenos, pois, com o objetivo de garantir à criança uma segurança material e afetiva para além dos riscos implicados na relação conjugal, e independentemente das aspirações individuais e das liberdades da qual cada um dos pais pode prevalecer-se, transferiu-se o ideal de indissolubilidade do casamento para o ideal de indissolubilidade da filiação (PIOLI, 2006). Passou-se a insistir, e mesmo a se normatizar, que os deveres e direitos parentais deveriam manter-se e prevalecer, independentemente dos laços conjugais. Em nome dos interesses da criança, centrou-se a atenção nos pais ${ }^{82}$.

A problemática do divórcio deixou de destacar-se diante dos interrogantes gerados pelas novas configurações familiares e pelas promessas e realizações no campo da procriação medicamente assistida. Contudo, a guarda das crianças mantém-se como um tema presente nos debates atuais no Brasil, principalmente a partir da introdução da noção de interesse da criança - também expressa pelos termos bem da criança, ou melhor interesse da criança - central para situarmos as atuais ficções jurídicas em torno da infância e da família.

Apesar de bastante debatido em nosso país, o Instituto da Guarda Compartilhada não é assunto tão recente no âmbito jurídico. Sua história tem origem nos anos 1960, na Inglaterra, onde ocorreu a primeira decisão sobre a guarda compartilhada (joint custody). Nesse caso, todas as partes foram ouvidas e ponderadas; entretanto, as decisões dos tribunais ingleses privilegiaram os benefícios e o interesse maior da criança e a igualdade parental. Tais precedentes repercutiram na França e no Canadá, sendo que o direito americano absorveu a nova tendência e a desenvolveu em larga escala. O fato em questão deixa bem claro que a origem da guarda compartilhada foi

\footnotetext{
${ }^{80}$ Em 2009 foram registrados cerca de 188 mil divórcios no Brasil, ou seja, para cada cinco casamentos há um divórcio (Fonte: IBGE) .

${ }^{81} \mathrm{Na}$ França, em 2004, quase a metade dos bebês nasceram de um casal vivendo em união livre (em 1965 apenas 6\% dos bebês teriam nascido "fora do casamento". (LAURENT, 2010a, p. 150)

${ }^{82}$ Neyrand (2006) cita pesquisas sobre a dificuldade da manutenção do laço paternal alguns anos depois da separação (50\% dos pais não vê nunca, ou vê raramente seus filhos após a separação conjugal) dado que contribuiria para a promoção da co-parentalidade conforme o interesse da criança.
} 
expressamente clamada pela criança, pelo desejo de continuar o convívio com seus pais e esse clamor foi plenamente compreendido e protegido pela $\mathrm{Lei}^{83}$.

No Código Civil francês, a autoridade parental é definida pelo artigo 371-1, que determina terem por finalidade os direitos e os deveres dos pais "o interesse da criança" e conclui anunciando um novo dever para estes: "Os pais devem associar a criança nas decisões que lhes concernem diretamente segundo a idade e o grau de maturidade" (GAVARINI, 2009).

No Brasil, a Constituição Federal de 1988 assegurou direitos iguais entre homens e mulheres, confirmando a igualdade de direitos e obrigações entre estes diante do casamento e dos filhos. Em harmonia com a Constituição da República está o Estatuto da Criança e do Adolescente, Lei 8.069/90, que contemplou a igualdade conjugal e a coresponsabilidade parental, obedecendo aos preceitos constitucionais, quanto à preocupação do melhor interesse da criança.

Com a Convenção Internacional dos Direitos da Criança (1989), tratado internacional do qual o Brasil é signatário, a criança passou a ser reconhecida como sujeito de direito $^{84}$ - o que tem contribuído para a evolução das crenças sobre $A$-Criança ${ }^{85}$. A criança também passou a "fazer" a família, dado que esta não é mais fundada pelo matrimônio. As decisões jurídicas concernentes à família passaram a ser regidas em nome do interesse da criança, e, a partir da introdução da noção de consentimento da criança, esta foi lançada irreversivelmente no centro de todo o processo: "A criança pode ser consultada nas questões relativas à sua educação, mas também em caso do divórcio contencioso dos pais. A doutrina jurídica deixou de considerar as 'necessidades da criança' à promulgação do 'interesse da criança' (GAVARINI, 2009, p. 6).

\footnotetext{
${ }^{83}$ C.f. - IBDFAM ACADÊMICO - Guarda Compartilhada: Novo Padrão Contemporâneo do Direito de Família. Disponível no endereço eletrônico: http://www.ibdfam.org.br/?artigos\&artigo=453.

${ }^{84}$ Destaca-se o caráter inovador do Estatuto da Criança e do Adolescente, promulgado em 1990, ao não contemplar somente a criança em "situação irregular", "carente" ou "menor", mas tratar do direito de todas as crianças e jovens brasileiros, considerando-os "sujeitos de direitos" e não mais "objeto de direitos".

${ }^{85}$ C.f. - LAJONQUIÈRE, L. (2010). Figuras do infantil. A psicanálise na vida cotidiana com as crianças. Petrópolis, RJ: Vozes.
} 
Dizer que a criança passou a fazer a família pode parecer uma metáfora, mas não é, trata-se de uma prescrição sustentada nas novas ficções jurídicas em torno da família: "Doravante, qualquer que seja a situação jurídica do casal, é o nascimento de uma criança que cria socialmente uma família" (Relatório da Missão da Assembléia Nacional sobre a Família apud LAURENT, 2010a, p. 150, tradução livre).

Considerada uma função, a parentalidade se decompõe em múltiplas dimensões (biológica, social, simbólica, genealógica); combinada com um sufixo, ela permite qualificar as configurações nas quais o parentesco social não corresponde ao parentesco biológico. Penso que quando é proposto que o termo parentalidade permite o descolamento entre o genitor e aquele que "ocupa o lugar", vale lembrar (mesmo que isso não consista em uma objeção ao uso do termo parentalidade para designar as novas formas de família) que desde as pesquisas empreendidas por Lévi-Strauss, a família é definida como um fenômeno de ordem cultural, não redutível ao acontecimento biológico (aspecto frisado por Lacan em 1838).

O termo parentalidade teria, então, se imposto para responder à questão seguinte: quem são os pais? Como melhor nomear aquele que ocupa o lugar de parent? Parte-se da constatação de que o léxico antropológico do parentesco não permite designar o fato de hoje não serem apenas os genitores a ocupar esse lugar e a desempenhar essa função. $O$ que estará cada vez mais em jogo será a vontade individual de ocupar este lugar (MARTIM, 2006b).

O termo "parentalidade" abre espaço à nomeação e ao reconhecimento jurídico de laços estabelecidos no âmbito da família e que, sem isso, ficariam no limbo. Reivindica-se, em última instância, a legitimação de laços parentais não oriundos de laços de sangue, ou melhor, o que está em jogo não é só a nomeação, mas a regulação ${ }^{86}$ desses laços. Retorno aqui a uma proposição de Tort (no capítulo 2): no que diz respeito às novas formas de família, a parentalidade revela-se uma invenção terminológica na qual se busca sair de uma contradição, retratando uma inventividade da definição prática. Ou seja, o que está agora em questão não é uma definição teórica, mas prática, amparada

\footnotetext{
${ }^{86}$ Maria Consuelo Passos (2005) alerta para a clandestinidade na qual vive boa parte das famílias homoparentais, ao não serem legitimadas social e juridicamente, de modo que a vergonha, a mentira e o silêncio são uma constante em suas vidas e um aspecto não descartável do ponto de vista da constituição da subjetividade.
} 
em práticas sociais já existentes e que precisam das ficções jurídicas para sair da clandestinidade.

O que vale destacar, do ponto de vista da psicanálise é que o irredutível da transmissão familiar não se garante com a introdução do termo "parentalidade" e que a família como resíduo não se confunde com o amor parental pelos filhos. Aliás, não há garantias na transmissão e, menos ainda sobre seus efeitos; ou seja, desse risco, nem uma nova terminologia nem as ficções jurídicas ou as políticas de apoio à parentalidade podem nos liberar.

Em referência a essa vertente do termo parentalidade, ela parece dar conta das transformações na família ao nomear e regular o lugar daqueles que assumem as funções parentais, para além das figuras biológicas de pai e mãe. Entretanto, devemos ser cuidadosos ao pretender estendê-la a outros campos, porque, como veremos a seguir, o termo parentalidade não é dissociável dos discursos que lhe são subjacentes. Se, por um lado, a parentalidade é convocada para legitimar novos laços familiares, por outro veremos que, ao oferecer-se PARA TODOS os pais, produz um efeito de homogeneização, normalização e diluição das diferenças no campo da família.

\section{3 - A parentalidade como um discurso de ordem pública}

Há ainda uma terceira vertente de investigação e de investimento na parentalidade: a parentalidade como um discurso de ordem pública. Nessa vertente, situam-se os discursos veiculados pelo especialista da família, pelos profissionais implicados no atendimento direto às crianças e às suas famílias e pelos poderes públicos em sua preocupação manifesta com os rumos das famílias na atualidade.

Darei continuidade ao estudo sobre o neologismo parentalidade a partir de um recorte sobre as origens das políticas públicas de apoio à parentalidade na França. Nesse percurso, veremos que o termo, além de se referir a teorias psicológicas e de representar um facilitador para o ordenamento dos novos laços familiares pelas ficções jurídicas, é também indissociável do discurso no qual se origina e das práticas que lhe são subjacentes. 
Fablet (2008) localiza a emergência do neologismo parentalidade no fim dos anos 90 e avalia que a promoção do termo se deve menos aos pesquisadores ou a uma disciplina universitária do que à evolução dos meios profissionais ligados à proteção da infância. Ações de sustentação à parentalidade constituem uma categoria de ação dos poderes públicos e foram concebidas no fim dos anos 80 para melhorar as condições do acolhimento institucional à primeira infância (PIOLI, 2006). Cabe a pergunta: em que se converteram essas ações? Como se define atualmente o perfil de família a que se destinam? Em que discursos elas se fundamentam?

Vale observar que no Brasil não dispomos da mesma variedade de dispositivos institucionais voltados à primeira infância que são ofertados na França. Tampouco dispomos de instituições mantidas pelo poder público contemplando também os pais, como os Centros de Acolhimento pais-criança que se instituíram inspirados na Maison Verte, a partir de políticas de apoio à parentalidade. Acredito que, em nossa realidade, é possível encontrar o investimento e a propagação de discursos sobre os pais na atualidade no campo das instituições de acolhimento e da assistência pública e no campo da educação (pública e privada, no âmbito das creches, berçários, escolas de Educação Infantil e Ensino Fundamental). Vale ressaltar que, na realidade brasileira, além das instituições públicas, há uma oferta crescente de dispositivos voltados a pais e crianças propostos pela iniciativa privada, assim como de produtos e publicações específicas, incluindo um mercado editorial de autoajuda ${ }^{87}$ e de aconselhamento aos pais em ascendência.

Veremos adiante, junto com Volpe (2011) que, na realidade brasileira, os produtos e os discursos são veiculados pelo "especialista da subjetividade". A produção desse profissional está muito menos ligada à pesquisa universitária ou a instituições científicas que à evolução dos meios profissionais ligados à infância e à educação, leitura que é condizente com a de Fablet (2008) sobre a emergência do termo parentalidade na França, como vimos acima. Outro modo de dizê-lo é que o termo parentalidade está diretamente relacionado aos discursos sobre a família produzidos na atualidade, os

\footnotetext{
${ }^{87}$ É nesse sentido que penso que o mal-estar na atualidade se particulariza na família. A ascendência da autoajuda e do aconselhamento não é uma característica exclusiva dela família, mas um traço do modo predominante nesta época de fazer frente ao mal-estar que é a civilização.
} 
quais, de acordo com Volpe (2011) adquirem particularidades no cenário contemporâneo.

\subsection{1 - As origens das políticas públicas de apoio à parentalidade na França}

Um relatório preliminar da comissão de prevenção do Grupo de estudos parlamentares sobre a segurança interior $^{88}$, publicado em 2004, enfatizou recentemente a importância do período da primeira infância (0-3) no domínio da prevenção da delinquiência, situando os pais, que devem ser apoiados pelas estruturas educativas ou sociais, no centro desse dispositivo de prevenção, sobretudo nos casos de famílias monoparentais ${ }^{89}$ ou recompostas (PIOLI, 2006). Localizo nesse tipo de proposição um discurso mais preditivo do que preventivo (GAVARINI, 2008) e mais político que científico (conforme o manifesto citado anteriormente). Sua lógica está em total contradição com o modo como o apoio à parentalidade foi concebido a partir do fim dos anos 80 pela administração social francesa, precisamente no domínio da primeira infância (PIOLI, 2006).

Atualmente, reivindica Pioli, o apoio à parentalidade se constitui como um elemento estruturante nas reflexões e intervenções relativas aos domínios da justiça, da saúde, do social e do familiar, envolve essencialmente iniciativas visando a estabelecer e reforçar os laços entre os pais e seus filhos, traduzindo-se em uma ferramenta para a emancipação dos indivíduos. Ainda que o autor critique modelos de intervenção preditivos, instituídos como instrumentos de controle, dificilmente encontraremos medidas que visam a estabelecer e reforçar os laços sociais e totalmente despojadas de mecanismos de avaliação e categorização, ou, ainda, das perspectivas de insuficiência e incompetência parental, como veremos a seguir. Afinal, como seriam tais iniciativas visando a estabelecer os laços entre pais e filhos? A partir de que tipo de avaliação, de critérios ou expectativas seriam organizadas? Veremos mais adiante a atitude radical que foi necessária aos profissionais da Maison Verte para manter o dispositivo psicanalítico ali instaurado sem responder à demanda avaliativa e categorizante das

\footnotetext{
${ }^{88}$ No original: Groupe d'études parlementaire sur la sécurité intérieure

${ }^{89}$ Possivelmente esse tipo de iniciativa está em conformidade com as pesquisas reunidas por Hazmad relacionando dificuldades de aprendizagem e delinquência e crianças educadas em famílias monoparentais (ver capítulo 2).
} 
instituições financiadoras, embora estas fossem importantes para a inscrição social e para a manutenção financeira do referido dispositivo.

Faz-se então necessário situar a lacuna estabelecida entre o modo como o apoio à parentalidade foi concebido e as práticas distorcidas que justificaria na atualidade. Pioli (2006) alerta para a dificuldade de apreender a questão do apoio à parentalidade a partir unicamente da lógica do controle social ou da pura lógica de emancipação, e, neste sentido, sua aproximação ao tema é visivelmente menos ingênua do que poderia parecer inicialmente.

No começo dos anos 70, com a diminuição significativa da mortalidade infantil, as políticas públicas começaram a voltar-se para a primeira infância (PIOLI, 2006, GAVARINI, 2004). A pequena criança passou a ser assimilada a um "capital da humanidade", a um "elemento portador de um projeto político de modernização e de emancipação".

Pioli observa que a pesquisa e o movimento relativo à parentalidade tiveram sua origem na opération pouponnières ${ }^{90}$, sustentada na vontade política de melhorar o acolhimento em instituições voltadas aos cuidados de crianças separadas de seus pais. Foram convocados pesquisadores já engajados nessa temática, como Myriam David, Geneviève Appell, Danièle Rapoport e Janine Lévy, para traçar uma ação voltada ao combate às perturbações decorrentes da separação (descritas inicialmente por René Spitz, John Bowlby e, depois, por Jenny Aubry). Logo a ação foi ampliada para o estudo sobre as maneiras de os profissionais melhorarem o acolhimento institucional. Dessa maneira, o autor situa a origem do termo parentalidade nas práticas de apoio aos pais de crianças "separadas" "91, que visavam se desvencilhar de uma perspectiva culpabilizante e concentrar-se em modos de manter as funções parentais em situações de ruptura.

A dinâmica sustentada no bem-estar da criança foi acompanhada por uma importante modificação das representações que os profissionais tinham acerca dos pais. Eles não seriam mais vistos como culpados (cujas falhas teriam legitimado medidas de

\footnotetext{
${ }^{90}$ Instituições de acolhimento a bebês e crianças de até 3 anos separados de suas famílias.

${ }^{91}$ Referência ao termo utilizado por Jenny Aubry no livro Psicanálise de crianças separadas. Rio de Janeiro: Campo Matêmico, 2004.
} 
substituição parental), mas passariam ao estatuto de vítimas. Seriam agora, aos olhos do poder público, "pais em sofrimento", que demandavam escuta e apoio. A ação profissional sofreu um giro importante: não se tratava mais de limitar as práticas parentais patogênicas, e a noção de cooperação passou a fazer parte da ação profisssional junto aos pais (PIOLI, 2006).

A passagem da culpabilidade dos pais para sua vitimização, relatada por Pioli, me levou a refletir sobre os riscos de serem tomados, por um lado, como vítimas e impotentes, instituindo práticas assistencialistas, que repercutem na dependência e na infantilização em relação às instituições mantidas pelo poder público e, por outro, como malagradecidos ao não se submeterem completamente (pais que tentam recuperar a subjetividade em um sistema que está organizado para despojá-los dela), reintroduzindo-se a via da culpabilidade e da distância dos mesmos em relação ao que se preconizaria como "bons pais". Nos discursos sustentados pelos profissionais da área social e educacional, os pais são lançados de um pólo ao outro: ora são vistos como vítimas, ora como abusivos.

Em 1994 foi criado um grupo de trabalho pluridisciplinar e pluri-institucional dirigido por Didier Houzel com o objetivo de trabalhar mais especificamente a parentalidade. Buscaram-se precisar as consequiências de situações de rupturas total ou parcial dos laços pais-filhos tanto para a criança como para cada um de seus pais, partindo das seguintes questões: em que medida há possibilidade de manterem esses laços e fortalecê-los, ou, ao contrário, de limitá-los? Em que condições a manutenção desses laços é favorável ao desenvolvimento psíquico da criança, ou, ao contrário, é prejudicial a ele? Qual o significado para a criança desses laços de filiação quando eles não estão mais em estrita correspondência com seus laços afetivos e educativos atuais?

Os especialistas reunidos sob a direção de Houzel propuseram distinguir, na parentalidade, o exercício (os direitos e deveres), a experiência (a dimensão subjetiva) e a prática (as tarefas cotidianas), e destaco, entre esses eixos, o modo como os autores se posicionam diante do primeiro. O "exercício da parentalidade" é entendido como próximo ao sentido jurídico, ao situar cada individuo nos seus laços de parentesco e com isso, nos seus direitos e deveres. O direito legisla os aspectos jurídicos do parentesco e da filiação, e diante da franca turbulência da evolução dos costumes e da 
reprodução assistida, é preciso discriminar laço biológico, laço social e laço jurídico. Houzel (2004) avalia que não se trata de tomar uma posição, mas adverte que faltam estudos informativos dessas situações (formas modernas de parentalidade e impacto sobre o desenvolvimento psíquico da criança):

Nosso dever, me parece, não é tomar posição, do que, aliás, me isentarei, mas chamar a atenção dos que decidem para além das considerações jurídicas ou de aspectos sociológicos desses problemas, sobre as consequiências para o desenvolvimento psíquico da criança da situação na qual aqueles que se encarregam dela exercem sua parentalidade $^{92}$ (p. 49).

Vemos aqui o modo como o discurso psicológico se entrecruza com o jurídico e é convocado ou se oferece como suporte para as decisões tomadas no âmbito do direito e mesmo para a elaboração de políticas públicas. Nesse caso, o autor pretende não tomar posição, mas reivindica que as decisões sejam tomadas a partir do modo como compreende a constituição psíquica da criança e as funções parentais.

A proposta do grupo de Houzel de diferenciar laço biológico, social e jurídico pode também ser encontrada em outros autores que verificam que esses laços guardam cada vez menos relação de dependência. Em Ceccarelli (2007) tais termos são traduzidos de outro modo: fato físico (o nascimento), fato social (o nascimento transformado em filiação) e fato psíquico (a filiação inserida em uma organização simbólica) para que a criança se constitua como sujeito. Avalio que a distinção proposta pode contribuir para que as ficções jurídicas se organizem de modo a reconhecer e a legitimar os novos laços familiares que se instauram na atualidade.

A partir do fim dos anos 90, o apoio à parentalidade passa a estar no centro de um processo maior. À ação preventiva procuram ser integrados os modos de auxiliar os pais na sua tarefa de pais, numa lógica que se propõe respeitadora dos indivíduos e valorizadora das competências parentais. Nessa perspectiva, os pais não são mais abordados como "demissionários" ou patogênicos por natureza, mas simplesmente como indivíduos esmagados pelo peso dos constrangimentos materiais, financeiros e pelos riscos da vida (PIOLI, 2006).

\footnotetext{
${ }^{92}$ Conforme marquei no capítulo 2, não tratarei de antecipar ou traçar um veredicto sobre o que será das crianças educadas nas novas configurações familiares. Recomendo àqueles que possam interessar-se sobre esse tema a leitura de artigos de Geneviè Delaise de Parsival.
} 
Com isso, o apoio à parentalidade deixa de se restringir a uma preocupação ou atenção especial com filhos de pais psicóticos, ou com crianças "separadas" de seus pais, e passa a se constituir em uma perspectiva que se estende a todos os pais, traduzindo-se em lógicas que envolvem práticas variadas, e muitas vezes, contrárias.

Consequentemente, todos os pais são concernidos potencialmente, ainda que alguns deles possam aparecer como tendo mais necessidade de ajuda. Com efeito, a função dessas ações não é unívoca, já que o apoio à parentalidade reenvia a dois eixos: o primeiro é horizontal, e propõe uma ação global destinada a todas as famílias. O segundo é um eixo vertical, e corresponde a uma perspectiva que se apóia sobre as populações alvo (PIOLI, 2006, p. 24, tradução livre, grifo meu).

O percurso realizado até aqui permite localizar na emergência do termo parentalidade os modos como o discurso da ciência penetra no âmbito da família, propondo medidas de apoio à parentalidade que partem da perspectiva de que haveria uma carência ou uma insuficiência parental. A leitura do estudo de Pioli permite identificar um discurso de ordem pública que vai adquirindo consistência ao se traduzir em iniciativas de apoio à parentalidade pressupondo uma insuficiência subjacente a TODOS os pais.

\subsection{2 - O especialista da família}

Não posso deixar de notar que, curiosamente, o termo parentalidade tenha surgido em uma época na qual a função, a disponibilidade e o lugar que ocupam os pais são questionados. Os pais são também acusados de delegar cada vez mais as funções que tradicionalmente assumiriam a instituições terceiras: escola, serviços de saúde e culturais e outros serviços oferecidos pelo "especialista da família". "As famílias são atualmente excessivamente culpabilizadas por antecipação: presumidas como demissionárias, fracassadas, ao ponto que se faz necessário apoiá-las" (GIAMPINO, 2006, p. 35, tradução livre). Um paradoxo presente no discurso público sobre a família é a passagem da família de excessiva a insuficiente:

Sabíamos que a família podia ser mortífera. Mas, depois da leitura das obras de Laing e Cooper, principalmente, era muito mais a um excesso de instituição que imputávamos seu caráter patogênico: a uma instituição que por excesso de instituído, de normas, de autoridade e de dominação era destruidora para os sujeitos. Hoje em dia, os maus tratos ou a violência intrafamiliar são, ao contrário, 
interpretadas como defeitos ou falhas da instituição (GAVARINI, 2008, p. 6).

Nesse contexto, oferece-se uma série de conhecimentos que traduziriam as funções parentais em termos de "competências" e que seriam disponibilizados aos pais ao modo de "como ser bons pais/boas mães". Os discursos sobre a parentalidade surgem como efeito de tais conhecimentos, apontando para uma inadequação, uma insuficiência dos pais concretos diante da tarefa de criar seus filhos. Essa dimensão normativa da parentalidade se estabelece assinalando quão distantes estão os pais em relação a um ideal possível - o impossível inerente à educação é forcluído não só das promessas veiculadas pelas tecnociências como também do discurso sobre a parentalidade que nelas se sustenta. Propõe, ainda, um modo de transmissão que poderia concretizar-se como tributário exclusivamente da função "parental", como se de um sujeito fosse possível separar o "parental", sem que essa "parte" fosse contaminada por outros aspectos (falhas e imperfeições), menos nobres, da subjetividade.

No Brasil, embora não disponhamos de uma rede de atendimento às famílias organizada da mesma forma que na França, é possível identificar na escola o mesmo discurso na forma de uma queixa, assim como a relação de causalidade que se estabelece entre as dificuldades apresentadas pelas crianças e as mudanças no campo da família, explicitada nas referências insistentes às "famílias desestruturadas". Na mesma medida, vem aumentando visivelmente a oferta de dispositivos (escuta de pais, escola para pais, orientação de pais) e de publicações voltadas aos pais, invocando as competências parentais, ou as melhores maneiras de bons pais produzirem crianças competentes. Vale destacar que mesmo que vejamos como legítimas as demandas por parte dos pais, é preciso separá-las das respostas que o "especialista da família" sente-se convocado a oferecer; pois é possível que estejamos diante de uma inversão: grande parte da demanda verificada nos pais na atualidade parece configurar-se a partir da oferta excessiva e generalizada sustentada nos discursos normativos da parentalidade ${ }^{93}$.

Ao fazer da família a causa principal dos problemas sociais, privatiza-se uma questão que é social, e, ao se diagnosticar que a família seria a responsável pelas dificuldades

\footnotetext{
${ }^{93}$ Essa observação me fez recordar uma constatação recente de uma orientadora educacional de uma escola de educação infantil: os pais têm procurado insistentemente a orientação da escola para certificarse de que seus filhos são "normais".
} 
apresentadas pelas crianças $^{94}$, se recai em um reducionismo (MARTIM, 2006b, GIAMPINO, 2006). Interessante observar que, por um lado, privatiza-se a culpa (o que é localizável na esfera social é atribuído à esfera familiar), mas, por outro, ou, no mesmo movimento, converte-se um fenômeno de ordem privada (a transmissão familiar) em um fato público (sustentado no "interesse da criança"): a proteção à família justificaria as ingerências do Estado (visando suprir a omissão familiar).

Vale lembrar que a intervenção do especialista no âmbito da família não é um fato recente. Pesquisadores como Christopher Lasch $^{95}$ e Jurandir Freire Costa ${ }^{96}$ dedicaram-se a estabelecer o cenário social no qual a figura do especialista se instituiu no final do século XIX. Lasch deteve-se, em sua análise, na realidade norte-americana, enquanto Costa investiu em circunscrever a realidade brasileira. Costa (1999) abordou o modo pelo qual o discurso médico passou a normalizar a sociedade brasileira, exaltando uma família higiênica. $O$ autor se refere aos médicos que intervinham nas famílias, consistindo em um braço interventor do estado na esfera privada, como "tradutores exclusivos do obscuro":

O controle higiênico era microscópico, detalhado, improvisado. Não havia um código claro, permanente, que orientasse o sentido das proibições. A higiene deu margem a este jogo de variações infinitas. Quase toda a atividade humana podia ser potencialmente mórbida (COSTA, 1999, p. 138).

De acordo com Volpe (2011), o discurso do especialista foi definido por Claude Lefort como "discurso técnico especializado", um discurso legislador e pedagógico, passando a reger as relações sociais. Lash identificou a figura do especialista com as novas "profissões auxiliares" da família, que supostamente dominariam as técnicas necessárias para mediar as relações sociais, partindo do consenso de que aquela não poderia mais dar conta de suas próprias necessidades.

\footnotetext{
${ }^{94}$ Em uma pesquisa, $65 \%$ dos professores avaliaram que o envolvimento da família na educação dos seus filhos é essencial para a melhoria na qualidade de ensino, porcentagem significativamente acima da que foi atribuída à importância da formação dos professores na qualidade do ensino. Fonte: MARCHESI, A. (2008) O Bem-estar dos professores. Porto Alegre: Armed.

${ }^{95}$ LASCH, C. (1991) Refúgio num mundo sem coração. Família: Santuário ou instituição sitiada? São Paulo: Paz e Terra.

${ }^{96}$ COSTA, J. F. (2004). Ordem médica e norma familiar. Rio de Janeiro: Edições Graal.
} 
Encontrei em Volpe (2011) um estudo sobre o modo pelo qual na atualidade o especialista se apresenta à família, ou seja, como ele comparece nesta época, diferenciando-se da figura "clássica" do especialista ou do "discurso técnico especializado". A autora não menciona em sua análise o neologismo parentalidade; contudo, parece descrever a lógica por meio da qual ele se insere - em sua vertente normativa e ortopédica - no cenário contemporâneo brasileiro. Embora eu prefira o termo "especialista da família", a autora opta por "profissional da subjetividade". Parece que Volpe, ao circunscrever a figura do especialista da subjetividade, mesmo sem utilizar o termo parentalidade uma única vez, faz referência ao discurso subjacente ao entendimento que haveria necessidade de um "apoio à parentalidade". Identifico essa proximidade entre o especialista e os discursos sobre a parentalidade quando a autora observa que o campo de atuação daquele é legitimado pela crença na inevitabilidade da intervenção ${ }^{97}$, justificada pela insuficiência dos pais para desempenhar suas funções.

O discurso do especialista da subjetividade, diferentemente do discurso científico, legitimado pela ciência e pelas instituições, se caracteriza pela visibilidade pública e pela expressão em grande escala, de modo que os profissionais regem suas carreiras mais pelas leis do mercado do que pelo discurso universitário, no qual a figura do especialista se firmou.

A pesquisa realizada por Volpe, além de circunscrever a figura do especialista da subjetividade, apresenta uma análise crítica do discurso por ele veiculado, mostrando como este se constitui por enunciados que são simplificações e diluições do conhecimento científico e especializado. Embora a autora reconheça no especialista da subjetividade o propósito de diferenciar-se dos profissionais que atuam na área da autoajuda ou do aconselhamento, identifica-o à literatura de autoajuda e a um simulacro de saber transmitido como conselhos, dicas e reflexões. As intervenções realizadas pelo especialista da subjetividade são normativas e refletem um determinado padrão de família, recaindo em generalizações e empobrecendo a discussão. Embora exista uma

\footnotetext{
${ }^{97} \mathrm{O}$ culto à autonomia e à performance, característicos dos discursos prevalentes na atualidade produzem sujeitos dependentes de todo tipo de ajuda especializada redundando em uma "autonomia assistida" que demanda serviços de apoio (BEZERRA, 2002). Deste modo, pode-se dizer que a inevitabilidade da intervenção consiste em um dos modos pelos quais os discursos prevalentes na atualidade se particularizam na família.
} 
tentativa de neutralidade, revela-se uma posição normativa, na qual se busca eliminar a imprevisibilidade e esclarecer todas as dúvidas.

Volpe é precisa é ao localizar o que denomina ambiguidade no discurso do especialista da subjetividade: ao mesmo tempo em que pretende devolver a sabedoria aos pais, revelando uma preocupação com a legitimidade de seu saber, tal preocupação não é suficiente para produzir uma alteração no vínculo estabelecido entre o especialista e o público. O especialista da subjetividade, apesar de pretender diferenciar-se de outros profissionais, recai em um discurso permeado por certezas, prescrições e conselhos. A autora assinala, ainda, que tal ambigüidade já estava presente nos especialistas e fora detectada por Lash no discurso médico americano dos anos 1950, quando comparecia como uma defesa da singularidade na relação entre pais e filhos e apresentava-se sob a forma de um "culto da autenticidade".

Assim sendo, se a presença do especialista não é um fenômeno novo na sociedade, na configuração social atual ele assume formas inéditas: trata-se de um discurso sustentado na lógica da literatura de autoajuda, governado pelo imperativo do mercado e não mais legitimado pela "autoridade intelectual" ou pela origem institucional de quem o profere. No entanto, constata Volpe, há alguns traços que se mantêm, como o consenso de que existem condutas adequadas e de que os profissionais dispõem desse conhecimento/técnica para fazê-las prevalecer. Outro traço mantido é a posição ambígua, já que as intervenções do especialista da subjetividade não promovem a independência dos pais. Um último aspecto, que já fora detectado por Lasch, é que os pais modernos acabam sentindo-se obrigados a ser pais perfeitos e encontram no discurso do especialista as certezas sobre como fazê-lo, promovendo uma aproximação entre a maternidade e a paternidade e o exercício de uma profissão. Eu acrescentaria outro traço, não destacado por Volpe, que caracteriza o cenário no qual o especialista intervém na atualidade: a preocupação em avaliar, medir e quantificar.

Vale destacar que a avaliação converte um indivíduo: de seu estado de único passa para o de um em entre outros, um ser comparável a outros e capaz de ser registrado pelas estatísticas (NAJLES, 2008 e MILLER; MILNER, 2006). A avaliação produz respostas que pretendem categorizar e homogeneizar grupos e depois geri-los. Instaura a lógica do usuário na qual, no caso da parentalidade, se supõe uma série de necessidades aos pais e 
filhos sem que eles tenham sequer que nomeá-las, e, se chegam a nomeá-las, isso não é necessariamente bem-vindo, pois pode contrariar os profissionais em questão. Esse é um bom exemplo de como o "interesse da criança", quando comparece como um imperativo, pode se sobrepor ao interesse de cada criança e à possibilidade de um sujeito (seja ele adulto ou criança) enunciar uma demanda. Trata-se de uma das facetas pelas quais a infância generalizada, preconizada por Lacan, comparece na atualidade.

Resta a indagação sobre o quanto não seriam os próprios profissionais os desencadeadores nos pais da expectativa sobre a existência de um bom modo de ser pai ou mãe, se essa demanda não seria gerada pela oferta do especialista que sustenta seu discurso numa avaliação pré-concebida dos pais como incompetentes e insuficientes, justificando a intervenção.

Um último comentário sobre a pesquisa de Volpe: a autora destaca o modo como a ilusão da existência de um "nós"98 se atualiza no discurso do especialista da subjetividade: ele costuma apresentar-se também como pai ou mãe, de forma que não haveria diferença entre o especialista e os pais; juntos, eles formariam um nós “[...] que compartilha da mesma experiência - ter filhos -, e das mesmas dificuldades" (VOLPE, 2011, p. 187).

Se o cenário em torno da insuficiência parental e da inevitabilidade da intervenção ganha cada vez mais consistência, há também autores e pesquisadores que, como Volpe, criticam essa posição e defendem um não-intervencionismo. Maïlat (2006) avalia que os profissionais devem se ressituar, uma vez que não são os observadores da família, os avaliadores do comportamento dos pais. A autora critica especialistas que querem nos fazer crer na existência de uma função "puro sangue" materna e outra paterna e que a atuação do bom trabalhador social consiste em observá-los, descrevê-los, contabilizá-los e, a partir de uma avaliação microscópica, enviá-los - ou não - ao juiz. Nessa perspectiva, a família estaria reduzida a um conjunto de competências educativas.

Ao dirigir-se aos trabalhadores sociais, Maïlat lembra-os de que não são exteriores à sociedade diante da qual se posicionam como observadores, mas fazem parte dela e, frequentemente, são também pais e sentem na pele o peso da avaliação externa de suas

${ }^{98}$ Tema que será desenvolvido no próximo capítulo. 
competências parentais, chegando inclusive a se misturar com os pais que criticam e destituem ${ }^{99}$.

Penso que se trata de estimular os pais a interceptar o discurso social assumindo os riscos e imperfeições que a transmissão - absolutamente singular - implica. Martim (2006b) propõe que os profissionais da infância e da família abordem a parentalidade de outra maneira:

[...] o que se precisa trabalhar é a condição parental e a maneira pela qual os pais falam de seu próprio papel; tentar levar em conta o ponto de vista e a palavra dos pais sobre a função que ocupam, procurar compreender como eles se tornam pais progressivamente em sua trajetória (p. 62, tradução livre).

Dessa forma, vários autores que se dirigem aos profissionais da infância, (MARTIM, 2006b, MAÏLAT, 2006 e GIAMPINO, 2006) avaliam que é preciso abordar os pais de outra maneira, que os profissionais se ressituem diante daqueles. Declaram inclusive que se trata de recusar a perspectiva de apoio à parentalidade: "Podemos eventualmente auxiliar os pais em suas tarefas educativas, apoiá-los nos momentos de dificuldades ligadas aos acontecimentos da vida. Não se trata em nenhum caso da parentalidade que deverá ser sustentada" (GIAMPINO, 2006, p. 34, tradução livre, grifo meu).

Partilho com Giampino a posição de que não se trata de apoiar ou sustentar a parentalidade e acrescento que as funções parentais não podem ser homogeneizadas, tampouco se conformam a partir de um universal. Destaco a seguir outra afirmação contundente da psicanalista, na qual pretendo me deter: "Apoiar a parentalidade, acompanhar os pais, deve ser, antes de querer corrigir as parentalidades, evitar arruinálas" (GIAMPINO, 2006, p. 43, tradução livre). Ainda que a autora não faça referência a Winnicott, o psicanalista inglês manifestava a mesma preocupação, assim como refletia sobre os danos que um especialista poderia causar ao interferir no campo da maternidade e da paternidade.

\footnotetext{
${ }^{99}$ Tal confusão aparece, por exemplo, quando educadores de abrigos que acompanham as crianças a atendimento psicológico viabilizado por uma rede profissional organizada por uma ONG, demandam à instituição que se responsabilize pelo atendimento psicológico de seus filhos.
} 
Destacarei a seguir a posição assumida por Winnicott ao identificar os riscos implicados na interferência do especialista no âmbito da família. Embora o psicanalista inglês não tenha recuado diante do convite de se dirigir aos pais em um programa da rádio BBC de Londres, veremos de que modo pensou ser possível dirigir-se a eles, já que estava advertido em relação aos riscos aí implicados. Na sequência, farei uma breve apresentação da Maison Verte, instituição de acolhimento a crianças pequenas e seus pais proposta por Françoise Dolto e um grupo de profissionais na década de 80.

Chamo a atenção para o fato de que este dispositivo institucional é contemporâneo ao movimento que culminou, na França, com a política de apoio à parentalidade, pois resulta de um projeto absolutamente particular, constituindo-se em uma instituição radicalmente diferente das que lhe são contemporâneas. Sua presença neste capítulo pretende marcar a resistência dos profissionais da Maison Verte ao discurso científico, homogeneizante e avaliador - que, como vimos, é subjacente à noção de parentalidade em sua dimensão normativa e ortopédica - para manter a ética psicanalítica como um eixo do dispositivo institucional.

\subsection{3 - Winnicott e o apoio negativo aos pais}

A família é abordada por Winnicott diversas vezes, em inúmeras publicações. Concentrarei minha atenção em dois textos do livro A família e o desenvolvimento individual, publicado pela primeira vez em inglês, em 1965. Em "Aconselhando os pais", o psicanalista (vale lembrar que Winnicott, assim como Dolto, fez o percurso da pediatria à psicanálise) adianta aos leitores que sua expectativa é a de que, após a leitura, eles se sintam menos preparados e menos inclinados a dar conselhos aos pais. Ainda que o autor não o formule dessa forma, o que faz nos textos é justamente separar a demanda dos pais das respostas que o especialista se sentiria inclinado a fornecer. Adverte que sua expectativa não deve levar o leitor a extremos: quando um médico está diante de uma doença que conhece, é seu dever dar as respostas a quem as pedir.

Em seguida, Winnicott descreve uma situação bem ilustrativa em relação ao que pretende transmitir aos seus leitores: relata uma consulta médica motivada por um problema nas amígdalas, na qual o médico conversa um pouco com a mãe, após o diagnóstico e a prescrição, e ela lhe diz que o filho tem sofrido violência de outras 
crianças e que pensa mudá-lo de escola. O médico diz à mãe que acredita na necessidade de ela mudá-lo de escola. Nesse ponto, Winnicott interrompe o relato assinalando que o médico saiu de seu domínio e teve uma atitude autoritária. Avalia que, ao escutar a mãe, o médico, sem sabê-lo, teve uma "atitude benéfica", mas ao aconselhar, tomou uma atitude irresponsável e desnecessária, dado que a mãe não lhe pedira sua opinião. O exemplo, aparentemente simples e corriqueiro, denota a sensibilidade do psicanalista para a intromissão do especialista no âmbito privado da família, para os riscos implicados em se sair do campo específico de atuação e para o fato de, neste deslocamento a um campo no qual não estaria autorizado a manifestar-se, o especialista carregar a autoridade que lhe confere o discurso médico.

O problema é: devem eles (aqueles que tiveram formação em medicina orgânica) dar um passo além de suas habilidades especiais e ingressar no campo da psicologia, isto é, da vida e do viver? Eis minha resposta: sim, se eles forem capazes de guardar e conter em si mesmos os problemas pessoais, familiares e sociais com que são colocados em contato, deixando que a solução apareça por si só (WINNICOTT, 2001, p. 173).

O psicanalista preocupa-se em precisar não só a diferença entre escutar e intervir, mas que intervir torna-se desnecessário nos momentos em que escutar é absolutamente efetivo. Assim, introduz um corte entre a demanda e a resposta produzida, levando os leitores a se questionarem sobre a pertinência de seus comentários no exercício de suas atividades profissionais. De fato, em minha atuação na formação de professores, verifico que frequentemente eles se sentem impelidos a responder às demandas dos pais, quando muitas vezes seria interessante apenas escutá-los.

Winnicott mostra-se extremamente sensível às interferências do especialista no campo da família, sobretudo no caso de bebês e crianças pequenas e, sem ser prescritivo, deixa bem claro o que não deve ser feito no contato dos profissionais com os pais. Oferece pistas para uma posição possível diante da demanda destes: a observação, a possibilidade de escutar e, no máximo, devolver aos pais o que eles contaram e de “deixar que a solução apareça por si só”. Adverte ainda sobre a inadequação da expressão de juízos morais nesse tipo de contato. 
Em "Algumas considerações sobre o significado da palavra democracia"100, Winnicott (2001) avisa seus leitores que está ingressando em um terreno fora de sua área de especialidade. Ele descreve uma sociedade democrática como uma sociedade madura. Para Winnicott "maturidade" é sinônimo de saúde; logo, uma sociedade democrática seria também saudável. Pergunta: “Como se pode estudar o desenvolvimento emocional de uma sociedade? Tal estudo deve acompanhar de perto o estudo do indivíduo. Os dois estudos devem desenrolar-se simultaneamente" (p. 229)

Para Winnicott, a estrutura democrática é uma conquista de uma sociedade dotada de algum limite natural, ela deve possibilitar a eleição de governantes pelo voto livre e secreto, e nela o indivíduo - "se for suficientemente sadio" - responsabiliza-se por sua ação. "Nesta sociedade e nesta época, há uma proporção suficiente de indivíduos que atingiu um grau suficiente de maturidade emocional para que exista uma tendência inata à criação, à recriação e à conservação da estrutura democrática” (2001, p. 231).

$\mathrm{O}$ autor define o termo inato como as tendências naturais (hereditárias) da natureza humana que se desenvolvem e florescem no modo de vida democrático, o que pode ser lido como maturidade social e que só ocorre mediante o desenvolvimento emocional sadio dos indivíduos. "Se a democracia é maturidade, a maturidade é saúde e a saúde é algo desejável, é natural que procuremos saber se podemos fazer algo para promovê-la. Tomemos como certo que a simples imposição da estrutura democrática seria perfeitamente inútil" (WINNICOTT, 2001, p. 234).

O fator democrático dependeria do que foi feito ou não pelas famílias dos indivíduos. O autor propõe que se evite interferir nos lares capazes de dar conta de suas crianças, denominando-os "lares bons e normais", e adianta que a partir de seus 25 anos de trabalho, pode afirmar que esses lares são "costumeiros", desafiam todas as estatísticas, pois não aparecem nos jornais, não são espetaculares e não produzem homens e mulheres famosos.

Pontua, contudo, que os pais normais às vezes precisam de ajuda, mas se preocupa com o modo como ela pode ser oferecida: "Quem pode garantir que, ao buscarem

${ }^{100}$ Capítulo 18 do livro A família e o desenvolvimento individual, publicado pela primeira vez em inglês, em 1965. 
assistência, eles não serão roubados da responsabilidade que têm sobre os próprios filhos? Com isso, deixariam de ser criadores do fator democrático inato" (WINNICOTT, 2001, p. 235, grifo meu).

Winnicott se preocupa mais com os riscos implicados na interferência do especialista do que com a competência dos pais para criarem filhos "maduros". Ele legitima as demandas dos pais e pergunta-se sobre a posição a partir da qual o especialista responde, de que modo atualiza um saber e supõe - ou não - um saber nos pais, mesmo que pelas próprias faltas e imperfeições. O que o autor parece vislumbrar é que a interferência, além de constituir-se em ferramenta de controle social, acaba por destituir os pais de sua responsabilidade sobre os próprios filhos.

Como se respondesse antecipadamente ao que se configurou posteriormente (em nossa época) como uma política de apoio à parentalidade, Winnicott propõe um "apoio negativo" aos pais: "O melhor apoio consiste na atitude negativa de promover organizadamente a não-interferência na relação normal e boa entre mãe e bebê, bem como nos lares bons e normais" (2001, p.239).

Deve-se evitar interferir no lar bom e normal e o estudo da psicologia e da educação consistiria, de acordo com o autor, um esteio adicional.

A devoção que a mãe boa e normal dedica a seu bebê é um fato dotado de especial significação; a capacidade de atingir a maturidade emocional é resultado dessa mesma devoção. A interferência massiva neste ponto, por parte de uma sociedade, faria diminuir rápida e decisivamente o potencial democrático dessa sociedade, e certamente minoraria a riqueza de sua cultura (WINNICOTT, 2001, p. 247, grifos meus).

$\mathrm{O}$ autor parece se referir a um empobrecimento das relações, de uma forma geral como efeito da interferência massiva no âmbito da família. Nesse sentido, faz diferença se pensamos que os discursos normativos e ortopédicos vêm socorrer os pais no exercício de suas competências ou se entendemos que estão já na base do mal-estar parental na atualidade, contribuindo para o sentimento de insuficiência e incompetência parental.

O termo "lar bom e normal" utilizado por Winnicott pareceu-me inicialmente uma adjetivação, uma valoração da família, mas o modo como ele define o define - 
prevalente, costumeiro e não espetacular - tranqüilizou-me a esse respeito. Também chamou a minha atenção o fato de Winnicott, no artigo sobre a democracia, qualificar como "defeito" da família o fato de os pais não serem casados, terem um relacionamento instável ou estarem separados; tais pais não alcançariam a categoria de "bons e normais". Convém lembrar que esses textos foram concebidos em um contexto sócio-histórico no qual a suposta crise relativa à família ainda não havia sido deflagrada, sobretudo os fatos principais a partir dos quais tal crise adquiriu notoriedade (definição da autoridade parental, surgimento e demanda por reconhecimento das novas configurações familiares e avanços da procriação médica assistida). É certo que jamais saberemos como o psicanalista inglês teria se posicionado diante desse novo contexto; não sabemos nem mesmo se teria se posicionado, ou seja, se mostraria alguma preocupação em relação à constituição psíquica das crianças resultantes dos novos modos de constituir família.

Além disso, Winnicott (2001) refere-se a uma "família invicta"101, e isso, além de intrigar-me, merece algumas considerações. Reproduzo a seguir alguns trechos nos quais essa noção é utilizada pelo autor:

$\mathrm{Na}$ esmagadora maioria dos casos o lar e a família existem, permanecem intactos e proporcionam ao individuo a oportunidade de desenvolver-se quanto a esse importante aspecto (p. 132).

[...] quando a família permanece intacta e há unidade entre os irmãos, cada individuo tem diante de si a melhor das oportunidades de iniciar-se na vida social (p. 133).

É quando a família se rompe, ou ameaça romper-se que percebemos o quão importante é a família intacta. É verdade que a ameaça de desintegração da estrutura familiar não determina automaticamente o aparecimento de distúrbios clínicos nas crianças [...] (p. 133).

Inicialmente pensei que poderia tratar-se de um erro de tradução (o que não se verificou $^{102}$ ), dado que intacto remete a íntegro, ileso, não tocado. O que teria de permanecer intacto para que uma família pudesse produzir indivíduos maduros? Uma análise apressada apontaria para a idéia de que, para Winnicott, uma família na qual os

\footnotetext{
${ }^{101}$ Esta referência aparece no capítulo 11 "Família e maturidade emocional" do livro A família e o desenvol vimento individual.

${ }^{102}$ No texto original em inglês encontramos remain intact.
} 
pais se separam, por exemplo, não teria as condições necessárias para conduzir seus filhos à maturidade emocional. Mas o autor toma o cuidado de frisar que a “desintegração da estrutura familiar" não implicaria necessariamente o aparecimento de sintomas psíquicos em sua prole.

No mesmo texto, é possível destacar outro cuidado do psicanalista em relação às conclusões às quais os leitores poderiam chegar: "Por mais que uma família faça tudo do melhor por um dos seus filhos, isso não é garantia de que a criança vá desenvolver-se até atingir a plena maturidade"103 (WINNICOTT, 2001, p. 135). Pois bem, na família, não há garantias. Que Winnicott o formule desta maneira me tranqüiliza: mesmo que a família permaneça invicta, não há garantias.

Ao tomar como referência as formulações lacanianas sobre a família, situei que o que deve permanecer intacto é o formulado por Lacan como resíduo, o irredutível da transmissão: a função da mãe, cujos cuidados levam a marca de um interesse particularizado, ainda que pela via das próprias faltas e a função do pai, na medida em que seu nome é o vetor de uma encarnação da Lei no desejo. No mais, não há família intacta. Não há família intacta em relação às mudanças que ocorrem no laço social, não há família intacta desde e sempre que exista família. Mesmo que Winnicott atribua a desintegração a separações, conflitos ou instabilidades conjugais, teríamos que pensar que a morte de um dos cônjuges, por exemplo, promoveria tal desintegração; de modo que ficamos sem saber o autor ficaria alarmado diante das famílias nas modalidades pelas quais elas se apresentam na atualidade. Mas, intactas ou não, na família não há garantias, e o psicanalista inglês é claro nesse ponto!

Apesar da preocupação com a interferência do especialista na família, Winnicott não recusou o convite para fazer um programa de rádio na BBC de Londres; entre 1939 e 1962, ele proferiu cerca de 50 palestras radiofônicas dirigidas aos pais, e o livro Conversando com os pais reúne todas as realizadas depois de 1955. Winnicott (1999) inicia o capítulo 1, intitulado "Educação para a saúde através do rádio", com o seguinte comentário: “[...] deve ficar claro que não sou, na verdade, especialmente favorável à

\footnotetext{
${ }^{103}$ Lembremos que para o autor "maturidade" é sinônimo de "saúde". O modo como define um adulto maduro, aparentemente simples, é, a nosso ver, digno de nota: "Pode-se dizer que o adulto maduro é capaz de identificar-se a agrupamentos ou instituições sociais sem perder o sentido da continuidade pessoal e sem sacrificar em demasia seus impulsos espontâneos [...]" (p 137).
} 
educação para a saúde em moldes massificados" (p. 1) e prossegue deplorando as intervenções que pretendem dizer aos pais o que têm de fazer, uma vez que recorrem desavisadamente a qualquer um que lhes fale com autoridade, por se sentir culpados. Mais uma vez, localizo em Winnicott a preocupação em separar a demanda dos pais da resposta que os profissionais se sentem convocados ou tentados a fornecer ${ }^{104}$. No seu programa de rádio, o psicanalista procurava apreender as coisas comuns que os pais faziam e ajudá-los a compreender porquê delas, advertindo ser impossível tratar anormalidades graves ${ }^{105}$ pelo rádio. $\mathrm{O}$ autor, sem defini-lo dessa maneira, parece circunscrever o "apoio negativo aos pais" com as seguintes palavras:

Quando se diz às mães que façam isto ou aquilo, não tardam em ficar confusas e (o mais importante de tudo) perdem o contato com a sua própria capacidade para agir sem saber exatamente o que está certo e o que está errado. É facílimo fazer com que se sintam incompetentes (WINNICOTT, 1999, p. 6, grifo meu).

Vale lembrar que é na incompetência parental que o discurso da ciência, aspirando a elidir o impossível estrutural da educação, encontra brechas para intervir, embora ao mesmo tempo ele mesmo discurso contribua para que os pais se sintam incompetentes e insuficientes para desempenhar os papéis de pai e mãe.

\subsection{4 - Françoise Dolto e a Maison Verte}

Quando o tema é a contextualização das investigações e políticas públicas na França voltadas à primeira infância, aos pais e à prevenção, na década de 70, a originalidade e a inovação do dispositivo implementado na Maison Verte aparecem notadamente (ELIACHEFF, 2004, LAJONQUIÈRE, 2010).

\footnotetext{
${ }^{104}$ Nos seus programas de rádio, Dolto criticava os saberes pedagógicos e se recusava a dar aos pais regras educativas referentes a um sistema de valores particular, assim como se recusava também a fornecer indicadores cronológicos; marcava dessa forma que o ritmo e a história própria do desejo da criança devem ser sustentados (FRANÇOIS, 1992).

${ }^{105}$ Nos seus programas de rádio, os pais dirigiam a Dolto perguntas que geralmente se referiam ao cotidiano das famílias: o sono, o ritmo diário, o controle dos esfíncteres, a entrada na pré-escola, etc. Algumas vezes eles traziam dificuldades mais específicas e, quando a situação parecia mais grave, Dolto enfatizava a necessidade de os pais recorrerem a uma ajuda especializada. Assim como Winnicott, mostrava clareza sobre os limites e alcances das intervenções.
} 
A Maison Verte ${ }^{106}$ foi aberta em 1979, como um lugar de encontro, de socialização, de escuta e de trocas para tudo aquilo que envolve a chegada de uma criança, contando com a presença de profissionais formados em psicanálise e onde a interdição é legitimada ${ }^{107}$. Um lugar no qual se endereça à criança, onde seus atos têm um sentido. Esse endereçamento se origina na constatação de Françoise Dolto de que se fala das crianças, mas pouco se fala com elas.

O dispositivo implementado na Maison Verte articula-se em torno de dois conceitos principais: laço social e subjetivação. Pretende-se ofertar um lugar intermediário entre a vida familiar a o espaço coletivo, que favoreça a relação precoce pais-criançassociedade, sem, contudo, identificar-se à obrigação de socialização precoce preconizada pela civilização ocidental (THIS, 2007). Sustenta-se na possibilidade, criada por Dolto, de uma utilização social da psicanálise, baseada em sua idéia de prevenção desta psicanalista, implicada tanto nas suas transmissões na rádio ${ }^{108}$ quanto na Maison Verte.

A Maison Verte se apresenta como um "lugar onde o que importa é falar com várias pessoas sobre o comportamento das crianças, num clima social acolhedor, que dissipa a ansiedade e desculpabiliza pais e filhos" (LEDOUX, 1991, p. 186). Com isso, contribui para minorar a solidão dos pais e metabolizar as relações excessivamente exclusivas entre eles e os filhos. Ali os pais podem se ocupar de seus próprios filhos, comparar

\footnotetext{
${ }^{106}$ Como para sua abertura a fachada fora pintada de verde e como as crianças já a nomeavam "Casa Verde", esse nome foi mantido. No entanto, algo do chiste se instaurou no nome, dado que se falava da Maison Verte (Casa Verde) e da Maison Ouverte (Casa Aberta): a sonoridade permitia o equívoco, que foi escutado por This (2007) como referido às outras tantas instituições que foram inauguradas em toda a França e em outros países, assim como à abertura na qual os fundamentos dessa instituição repousavam.

${ }^{107}$ Na Maison Verte há algumas regras que devem ser observadas. Para as crianças: os brinquedos não podem ser levados para casa, pois eles pertencem a todos; para brincar com água, é necessário vestir o avental, para brincar com as motocas, é preciso respeitar a linha vermelha que delimita a zona para esta atividade. Para os adultos: a presença do adulto tutelar é obrigatória.
}

${ }^{108}$ Em 1977 a rádio France Inter convidou Dolto a participar de uma série de emissões destinadas a ajudar os pais com dificuldades com seus filhos. Mesmo que a proposta fosse ao encontro de suas preocupações do momento, ela hesitou em aceitar (FRANÇOIS, 1992). No primeiro tomo de Quando a criança aparece, Dolto faz o seguinte comentário: "Não seria então possível ajudar os pais em dificuldades a expressar-se, a refletir sobre o sentido das dificuldades de seus filhos, a compreender estes e a acudi-los, no lugar de procurar fazê-los se calar ou ignorar os signos do sofrimento infantil [...] Informar os pais, responder a sua demanda de ajuda. Desdramatizar as situações bloqueadas. Desculpabilizar uns e outros, a fim de despertar os poderes de reflexão [...] Isso seria possível? Não teria que tentar fazer a experiência? [...] Certamente não se tinha que esperar muito deste tipo de emissão, mas seria esta uma razão para se subtrair a isso? Certamente isso provocaria, por mais que se dissesse, muitas discussões? Mas seria esta uma razão para não provar?" (DOLTO apud FRANÇOIS, 1992, p. 183/184, tradução livre). No mesmo momento em que a Maison Verte abria suas portas, os três livros que testemunhavam o diálogo de Dolto com os ouvintes da emissão de rádio da France-Inter eram lançados. 
suas atitudes educativas, conversar com outras pessoas que possam auxiliá-los em suas dificuldades. O que se lhes demanda é que acompanhem seus filhos, que permaneçam e que contribuam com uma participação financeira.

A Maison Verte não pretende confundir-se com um berçário, com uma creche ou com um centro de atividades organizadas. Os autores do projeto são enfáticos: ela não pode ser comparada a outras instituições criadas para responder às demandas dos adultos. Diferencia-se, ainda, de um espaço de tratamento, de um espaço pedagógico, ou de uma escola para pais: "Dolto insistia em que esses centros de lazer da primeira infância não fossem burocratizados, medicalizados e psicologizados, mas permanecessem como uma espécie de jardins públicos abertos, sem matrícula e sem instrução" (LEDOUX, 1991, p. 186).

Um dos fundadores ${ }^{109}$, Bernard This (2007), justifica o distanciamento que a Maison Verte assume em relação às escolas para pais: não é com princípios educativos de outros que se educa um filho; os pais não esperam receber conselhos ou técnicas. A especificidade da Maison Verte parece residir não apenas no que ela se propõe a fazer, mas naquilo a que se recusa, estabelecendo-se em uma total ruptura com relação às estruturas médico-pedagógicas ou assistenciais clássicas.

É preciso um certo cuidado ao abordar o pedido de conselhos por parte dos pais. A formulação de This pode levar a estabelecer que "bons pais" seriam aqueles que sabem que, na transmissão, não se trata de se orientar por conselhos. A observação de Malandrin (2009), que também está entre os fundadores da Maison Verte, de que os pais demandavam mais conselhos no início faz pensar que a demanda diminui diante do modo pelo qual é tomada nesee dispositivo.

Bernard This, em seu livro dedicado à Maison Verte, pergunta: Por que os pais vêm à Maison Verte com suas crianças? "[...] é a própria situação, mais que nossas intervenções de toda maneira muito marginais e que explicam apenas parcialmente os efeitos benéficos constatados" (2007, p. 56, tradução livre). Entendo que o que This define como "a própria situação" remete ao fato de que a estrutura de acolhimento

\footnotetext{
${ }^{109}$ Formavam a equipe fundadora da Maison Verte Françoise Dolto, Bernard This, Pierre Benoit, Colette Langignon e Marie-Hélène Malandrin.
} 
representa, para pais e crianças, um primeiro encontro com o coletivo, um encontro mediado pela presença dos pais da palavra, mediado também pela presença da interdição. Nesta instituição se propicia uma experiência em um espaço coletivo preservado em relação à perda necessária de gozo, um espaço no qual esta é legitimada ${ }^{110}$ e que pode então servir de amparo aos pais naquilo que tem se convertido em tarefa hercúlea: interceptar - de modo singular - o discurso social, na tarefa educativa de enodar laço social e subjetividade.

Ao diferenciar-se das instituições pedagógicas e de tratamento e situar a psicanálise no centro do dispositivo, a Maison Verte se estabelece em ruptura com o referencial da cura, que marcou a origem da psicanálise. Lembremos que o referencial da cura funciona com hora marcada, situa-se a partir de uma demanda, põe em jogo a questão diagnóstica, aspectos propositadamente ausentes nessa instituição. Com isso, a presença da psicanálise e dos psicanalistas na Maison Verte foi colocada em xeque, e Françoise Dolto, cujas idéias estão na base do projeto, foi duramente criticada, não só por propor a psicanálise para além do dispositivo da cura como também pelo modo como se dirigiu aos pais, muitas vezes de forma diretiva ${ }^{111}$, sustentada em um ideal de prevenção. $\mathrm{O}$ risco dessas críticas é invalidar a inventividade e a sensibilidade presentes na escuta e nas intervenções de Dolto, tanto na clínica como na instituição.

A Maison Verte se consolida como um dispositivo institucional absolutamente singular ao oferecer um espaço no qual a psicanálise se inscreve e convida coletivamente à escuta singular de todos aqueles que atravessam suas portas. Há mais de 30 anos, vem permitindo que pais e crianças, sem dossiês nem papéis, possam encontrar um psicanalista, sem a obrigação de uma cura psicanalítica (THIS, 2007). Essa experiência não só abriu o caminho para a pesquisa sobre os efeitos da presença do discurso psicanalítico numa comunidade assim como permitiu ainda que inúmeros profissionais da primeira infância se posicionassem diferentemente em sua prática profissional (psicólogos, trabalhadores sociais, pedagogos e etc.).

\footnotetext{
${ }^{110}$ Lebrun (2004) detecta no indivíduo contemporâneo a pretensão de livrar-se da perda de gozo que a vida na comunidade exige e, nas instituições, a dificuldade de sustentar essa perda necessária. LEBRUN, J.-P. (2004) Um mundo sem limite: ensaio para uma clínica psicanalítica do social. Rio de Janeiro: Companhia de Freud

${ }^{111}$ Malandrin (2009) pontua que Dolto precisou de um certo tempo para moderar a tonalidade e rapidez de suas intervenções, tendo que se lembrar de que estava num centro de acolhimento.
} 
O anonimato está no centro do dispositivo, mesmo que possa gerar certo mal-estar no público atendido, nas equipes de trabalho e, sobretudo, nas agências financiadoras, preocupadas em medir e produzir dados estatísticos. Com o anonimato, recusa-se a formalidade de inscrição e a visada pedagógica ou diagnóstica, já que não se pretende avaliar as crianças ou produzir dossiês médicos ou administrativos.

No entanto, a presença do anonimato não implica a oferta de um acolhimento anônimo. Vale explicitar de que forma este dispositivo se atualiza no cotidiano da instituição. Quando a criança chega, seu nome é anunciado e registrado numa lousa, seu sobrenome não é demandado. Acredita-se que o sobrenome esteja ligado à identidade civil e social, mais que à construção de sua identidade afetiva. A finalidade da regra é silenciar o estatuto social das famílias, um silêncio que liberaria os pais e os profissionais do imaginário no qual encerram certas profissões, certas situações, certos nomes. O que está aqui em jogo é uma tentativa de dar um tratamento à dimensão imaginária de modo que ela não seja a norteadora da escuta e das intervenções dos profissionais. Vejo nessa tentativa - desde que seja tomada sempre como uma tentativa e não como uma pretensão de exclusão da dimensão imaginária - um cuidado importante no que se refere às relações estabelecidas entre as famílias e os profissionais, sobretudo quando estes últimos se autorizam a intervir, orientados por uma leitura de ordem imaginária. Estas intervenções ocorrem cotidianamente nas instituições educacionais ou assistenciais, quando, por exemplo, atribui-se a uma mãe ou um pai que não levam ou buscam seu filho nas atividades o adjetivo de "pais ausentes" ou atribui-se às famílias recompostas ou monoparentais a pecha de "famílias desestruturadas".

Malandrin lembra que a regra do anonimato surpreende mesmo na França. Foi aceita pelo poder público no projeto inicial, mas incomoda muito os financiadores que veem nela uma contradição ao desejo de prevenção e controle. Em uma entrevista ${ }^{112}$ realizada com Malandrin, Schauder (2009) diz que o anonimato se justifica, sobretudo atualmente, diante da ascensão do discurso científico nas instituições, como uma "proteção" diante de pesquisadores que preconizam a política de prevenção, mas uma

\footnotetext{
${ }^{112}$ A publicação mais recente sobre a Maison Verte data de 2009 e recebe o título Uma psicanalista na cidade, a aventura da Maison Verte. Foi organizado por Marie-Hélène Malandrin e está dividida em três grandes partes. A primeira se apresenta sob a forma de uma entrevista, concedida a Claude Schauder - que recebeu o título: educação/psicanálise, um enodamento impossível? A segunda reúne documentos de arquivos da Maison Verte (1976-1992) e a terceira é uma compilação de textos de Françoise Dolto sobre a Maison Verte (1978-1988).
} 
prevenção que se atualiza sob a forma de uma predição. Malandrin pontua, na sequência, que o anonimato, como um dispositivo institucional, não pode ser reduzido ao desejo de se proteger do controle social ou dos avanços do discurso científico.

Pierre Benoit também se preocupa em situar esse dispositivo institucional em relação aos avanços do discurso da ciência ou ao que vem sendo nomeado como mal-estar na atualidade. Pontua que, se outrora o mistério sobre as origens estava a cargo da religião, o discurso da ciência se apresenta na atualidade como detentor das respostas a essa questão; com a psicanálise, no entanto, não se pretende responder a ela e sim procurar mantê-la em aberto. O autor localiza a errância do sujeito moderno como algo que a Maison Verte se esforçaria por prevenir. O que está em jogo, 30 anos depois de sua abertura, é a atualidade desse dispositivo, tema ao qual Aubourg (2009) se dedica e que mobilizou os profissionais envolvidos no projeto a organizarem um colóquio $^{113} \mathrm{em}$ 2009.

Mesmo que a Maison Verte tenha contado desde o início com créditos públicos para se manter, Dolto não queria que ela se convertesse em uma nova instituição, com toda a carga de rotina, repetição e convenções que isso implicaria. This (2007) descreve os vários modos pelos quais Dolto e o pequeno grupo fundador da Maison Verte procuraram resistir à institucionalização e suas conseqüências. Entre esses modos destacam-se a organização dos profissionais em um colegiado e a recusa de uma estrutura hierárquica (com o objetivo de que os profissionais estivessem a serviço da instituição e não que se apropriassem dela), consolidando a Maison Verte como uma democracia institucional. $\mathrm{O}$ trabalho em tempo parcial e a presença de uma equipe a cada dia da semana têm como objetivo que nenhum dos profissionais monopolize a totalidade das informações ou possa reunir o conjunto da experiência vivida na instituição.

Uma nova equipe a cada dia da semana era uma regra indispensável aos fundadores para combater o desejo de mestria na dinâmica institucional, permitindo que cada um se engajasse no seu trabalho, com seu próprio estilo, mas sempre acompanhado de outros profissionais, de outros estilos. Nas equipes, relatam os fundadores, ninguém se arriscava a ser mais que os outros, a identificar-se com um lugar de mestria ou de

113 "La recontre: les 30 ans de la Maison Verte", realizado de 17 a 19 de outubro de 2009. 
detentor do saber. Penso que os riscos institucionais estão colocados para todos, mesmo para os mais advertidos, e, apesar dessa preocupação sempre presente e intrínseca ao dispositivo, as diferenças na formação, as tentativas de fazer prevalecer um discurso sobre os outros e as disputas institucionais fizeram parte do percurso da instituição e podem ser localizadas na leitura do livro de Bernard This, nos documentos e cartas reproduzidos no último livro sobre a Maison Verte e na entrevista que Malandrin concedeu a Schauder.

Contudo, destaco dois pontos essenciais que me parecem centrais na busca pela manutenção dos princípios que estiveram na origem do projeto da Maison Verte: o primeiro é o entendimento de Dolto que a paridade salarial ${ }^{114}$ (igualdade de salários entre todos os profissionais que atuavam na instituição) deveria ser garantida - Dolto ameaçou retirar-se do projeto caso isso não ocorresse -; o segundo é a recusa de submeter-se ao processo de avaliação proposto pela Fondation de France.

A eficácia do dispositivo é também atribuída ao fato de os profissionais - compondo uma equipe que se modifica a cada dia e para a qual há a preocupação de garantir pelo menos a presença de um homem ${ }^{115}$ - não se proporem como bons pais substitutos e não se identificam com um lugar de saber. Resta verificar se de fato este aspecto é preservado no fazer cotidiano desta instituição, ou seja, se não há um atravessamento de uma maestria nas relações que se estabelecem entre os profissionais e os pais. Ainda que algo de maestria ou prescrição possa escapar nas intervenções dos profissionais, o que me parece estar preservado na escolha por não traduzir este dispositivo em um modelo a ser replicado e por não fazer concessões diante das agências financiadoras é a manutenção de um lugar para invenção na intervenção sustentada no discurso psicanalítico $^{116}$ e no lugar de sujeito do desejo para a criança. Ao recusar-se à

\footnotetext{
${ }^{114}$ Esse ponto é aprofundado na entrevista concedida por Marie-Hélène Malandrin a Claude Schauder no livro Une psychanalyste dans la cité.

${ }^{115} \mathrm{O}$ esforço por garantir a presença de pelo menos um homem diariamente na instituição é abordado por Bernard This (2007). O autor fala em paridade, presença masculina e função paterna, procurando inscrever o cuidado em garantir a presença do pai - por exemplo, na decisão de abrir a instituição aos sábados à tarde - na leitura lacaniana da função do pai. Incorre, a meu ver, em uma imaginarização das formulações de Lacan. Aubourg (2009) apresenta uma explicação menos pretensiosa e mais simples acerca da presença dos homens no cotidiano da instituição: "a equipe é mista porque na idade em que estão em jogo as identificações sexuais, é importante que a criança possa ter uma aproximação com os dois sexos encarnados e não somente no discurso (p. 7, tradução livre).

${ }^{116}$ Malandrin (2009) observa que a psicanálise mantém sua vitalidade na Maison Verte, enquanto em outras instituições que recebem crianças ela permanece apenas como uma referência no âmbito das supervisões.
} 
avaliação ${ }^{117}$ e ao controle pelo poder público, a Maison Verte também recusou o "para todos igual" inevitável em qualquer política pública. Assim, dizer "não" para a institucionalização, para a avaliação e para a replicação é dizer "não" ao "para todos" os pais que ordena as políticas públicas que se instituem na mesma época na França, visando ao apoio à parentalidade. É neste ponto que a Maison Verte se define como uma instituição singular, impossível de ser enquadrada nos dispositivos existentes na atualidade.

A Maison Verte serviu de inspiração para outros dispositivos que foram criados ao redor do mundo (Bélgica, Rússia, Suíça e mesmo no Brasil, no Rio de Janeiro, com o nome de "A casa da árvore") e foi utilizada como modelo para o poder público francês para a criação de uma série de centros de acolhimento pais-criança ao redor do país. Contudo, recusou a proposta de compor uma federação de centros de acolhida, recusou a supervisão, a formação, ou filiação, acreditando que cada instituição deveria encontrar seu caminho e mesmo o caminho para financiar seu projeto. Schauder propôs a criação de uma federação para gerar impacto no poder público e nas demandas de avaliação que eram associadas à possibilidade de se obter um financiamento. A Maison Verte via como ilusória a possibilidade de estabelecer critérios comuns para fundamentar o trabalho realizado nos centros. Para Malandrin, tratou-se de uma escolha pela ética: "Em nome de que critérios comuns podemos validar esses centros? Sua legitimidade é conferida pelos pais, na utilização que eles fazem do dispositivo, que está a seu serviço e de sua criança" (MALANDRIN, 2009, p. 45, tradução livre).

Em 1991, a Fondation de France, responsável pelo financiamento das atividades desenvolvidas na Maison Verte, endereça-lhe uma carta adiantando um trabalho de avaliação a ser realizado, que permitiria valorizar sua ação junto a instituições locais e nacionais. Naquela época, essa Fundação mantinha aproximadamente 30 centros de acolhida pais-criança. Em 1992 foi unânime no grupo que atuava na instituição naquela época a decisão de se retirar deste estudo, decisão que gerou uma carta aberta ${ }^{118}$. Nesta,

\footnotetext{
${ }^{117}$ O tema da avaliação é tratado com rigor em duas obras recentes: NAJLES, A. R., (2008) Problemas de aprendizaje y psicoanálisis. Buenos Aires: Gramma Ediciones e por MILLER, J.-A. e MILNER, J.C.(2006) Você quer mesmo ser avaliado? entrevistas sobre uma máquina de impostura. São Paulo: Manole.

${ }^{118}$ Essa carta foi redigida por Marie-Hélène Malandrin e consta como documento n. 19, de abril de 1992. Reproduzo a seguir um trecho: "A Maison Verte é uma experiência que criou uma situação nova na cidade pela introdução deste 'dispositivo de trabalho'. Esta inovação na sua pesquisa 'clínica' não pode
} 
os profissionais mostravam seu ceticismo e suas sérias reservas acerca de uma avaliação objetivizante, que poderia induzir a distorções das opções de base assumidas na instituição (paridade de salários, rodízio diário da equipe, recusa de reunião de síntese, anonimato, etc).

Se, por um lado, a Maison Verte faz resistência aos avanços do discurso da ciência propondo um dispositivo no qual a criança é tomada como um sujeito, por outro, parece evitar identificar-se com um ideal, um modelo ideal de instituição, o que convém em um dispositivo que firma suas bases na ausência de ideais, de crianças ideais, de filhos ideais, de pais ideais. Sustenta-se, assim, como uma instituição furada, incompleta, não detentora de uma verdade válida para todas as outras estruturas de acolhimento paiscriança.

A atualidade desse dispositivo parece residir na possibilidade de fazer frente ao que se configura como um mal-estar na família na atualidade quando, de fato, o que se passa é a família vir sendo soterrada por convicções disseminadas pelo discurso da ciência, que converte o impossível da educação em impotência parental e, no mesmo movimento, promete certezas e ausência de riscos no desempenho de uma suposta competência parental. A Maison Verte faz resistência à avaliação, à normalização e ao discurso homogeneizante e assexuado da parentalidade, instituindo-se na singularidade e na inventividade do encontro com cada família.

\section{4 - A parentalidade como o sintomático desta época}

Vimos que o termo parentalidade surgiu a partir de estudos sobre a psicose materna, estendeu-se às pesquisas com crianças "separadas" de seus pais e, depois, de uma forma geral, às investigações que visavam fornecer subsídios às políticas de proteção da família. Interessa-me especialmente a passagem destacada por Pioli (2006) de uma

\footnotetext{
ser regulamentada administrativamente: o respeito pelo dispositivo e por suas regras testemunham um longo e necessário trabalho de elaboração pela equipe que busca sustentar a criança em suas questões, e as distorções do dispositivo revelam frequentemente as incompreensões estruturais deste lugar. Em geral, é a criança, em sua palavra e gesto - em corpo que se exprime, em comportamento que significa uma palavra a ser escutada - que corre o risco de ser ignorada. Este movimento de pesquisa deve ser mantido" (2009, p. 184, tradução livre)
} 
política de apoio à parentalidade fragilizada socialmente ${ }^{119}$ a uma política de apoio PARA TODOS os pais, pois quando o apoio à parentalidade se torna uma política pública, assume a dimensão do para-todos-igual, inevitável nesse campo e, no mesmo movimento, exclui o sujeito.

Situei no capítulo anterior o mal-estar parental na atualidade como resultado da tradução do impossível da educação em impotência; agora, penso ter reunido elementos para asseverar que o mal-estar parental atual é condensado no neologismo parentalidade, o qual, em sua base, aponta para uma insuficiência, para uma incompetência, para uma necessidade de apoio PARA TODOS ${ }^{120}$ os pais. No discurso normativo e ortopédico sobre a parentalidade, não há lugar para a singularidade, traço fundante e fundamental da família.

Encontrei em Peusner (2009) a formulação de que o mal-estar parental estaria motivado pelo sofrimento que a criança causa no Outro quando o confronta com o impossível na educação - daí podermos dizer que educação é mal-estar! - e este é tomado como impotência. Constata-se que, na atualidade, o discurso tecnocientífico incide nesse malestar, assumindo a forma do "especialista da subjetividade", prometendo a exclusão da categoria do impossível, mas nem por isso livrando os pais de sua impotência. Ao contrário, vale-se desta para interferir na transmissão parental, terreno privado e necessariamente sujeito a falhas, imperfeições, uma vez que permeado pelas modalidades de gozo que cada pai e cada mãe testemunham em sua transmissão.

Vale pontuar que o mal-estar na família condensa e particulariza o modo pelo qual ele é tratado na atualidade: um mal-estar que, ao denotar incompetência e insuficiência, deve ser suprimido e, de acordo com esse ponto de vista, demanda uma "intervenção corretiva" (BEZERRA, 2002).

\footnotetext{
${ }^{119}$ Gavarini (2006) observa que nesses casos se atualiza uma confusão entre pobreza e risco, mesmo que existam traços comuns entre as famílias-alvo dessas qualificações nas descrições dos trabalhadores sociais.

120 "Aliás, é desejável inculcar essa função parental nos pais "defeituosos", "incompetentes", naqueles que devem ser "reparentalizados" (GAVARINI, 2008, p. 14).
} 
Laurent (2007) propõe uma articulação entre o singular e o universal que contribui para a reflexão sobre o modo como se fundiu uma indissociável da necessidade de apoio aos discursos sobre a parentalidade. Advertido sobre o império do gozo como preço pago pela liberação e pela autorregulação na contemporaneidade, o psicanalista pontua: "No que diz respeito ao gozo, o psicanalista deve reenviar o sujeito à sua particularidade ${ }^{121,}$ (p. 172). Recorre à noção de serenidade, formulada por Heidegger como uma atitude de dizer simultaneamente sim e não ao mundo técnico ${ }^{122}$, e propõe a transição do vocabulário do filósofo para o campo do gozo, formulando que a visão hedonista do mundo faz desaparecer a singularidade do sintoma e apóia seu império no acesso ao gozo "para todos". Haveria dois tipos de relação com o gozo: querê-lo mais e querer a singularidade do sintoma. Não seria sensato atacar os objetos de gozo, mas:

Dizer "não" consiste em impedir que o pronto-para-gozar generalizado não esteja à escuta da singularidade de nosso sintoma. Seu envelope formal é contingente, não pertence a todos. Nesses termos, a serenidade do sujeito "igual em presença dos objetos de gozo" é não perder de vista a singularidade do caminho que lhe é próprio (LAURENT, 2007, p. 173).

Embora não o explicitem dessa maneira, Derrida e Laurent parecem ter escutado a recomendação de Lacan de que o analista deve estar à altura de sua época. Derrida, como vimos no capítulo 2, pontua que a transformação no campo social é indissociável da transformação no campo analítico. Laurent, por sua vez, pensa em "[...] um analista capaz de entender qual foi sua função e qual the corresponde agora" (2007, p. 143.) e formula o que poderia ser um alerta aos partidários do apoio à parentalidade: "Dito de outro modo, é preciso recordar que não se deve tirar de alguém sua particularidade, a fim de misturá-lo com todos no universal, em razão de algum humanitarismo ou qualquer outro motivo" (LAURENT, 2007, p. 145). O discurso sobre a parentalidade é mais um discurso hegemônico ao qual cabe à psicanálise não se deixar seduzir.

\footnotetext{
${ }^{121}$ Embora o autor use aqui o termo "particularidade", penso que pretende referir-se a "singularidade". Acredito que o mesmo ocorre no trecho em que ele pontua que "não se deve tirar alguém de sua particularidade".

${ }^{122}$ Reproduzo a seguir os trechos destacados de Heidegger por Laurent: "Seria insensato atacar, a cabeçadas, o mundo técnico [...]. Dependemos dos objetos que nos são fornecidos pela técnica" (HEIDEGGER, 1966, apud LAURENT (2007, p. 172) ; "Podemos dizer 'sim' e, ao mesmo tempo 'não' ao emprego inevitável dos objetos técnicos, no sentido de impedi-los de nos engolir e, assim, falsear, confundir e, finalmente, esvaziar o nosso ser. [...] Uma palavra antiga serve para designar essa atitude de dizer simultaneamente sim e não ao mundo técnico: Gelassenheit, 'serenidade', 'igualdade de alma'. Falemos então da alma igual em presença das coisas" (p. 173).
} 
A psicanálise se apresentaria, assim, como resistência à generalização, aos discursos que apontam para uma parentalidade incompetente ou deficitária, cabendo a ela responder reenviando cada família - e neste ponto insisto no significante "família" - à sua singularidade. Para a psicanálise, há cada família e não uma parentalidade! Não há transmissão se deixamos de fora a maneira pela qual cada sujeito conjuga seu modo de gozo singular na relação com o outro. Retomando: para que haja um neurótico, é preciso não apenas um pai e uma mãe, mas também um homem e uma mulher.

No capítulo anterior, assinalei que pretendia distanciar-me da oposição entre família e parentalidade e da leitura de que se deve proteger a família desta última. Contudo, embora o percurso realizado até aqui aponte para a manutenção da posição de que a transmissão (com suas faltas e imperfeições) opera e continuará operando para além dos discursos normativos e ortopédicos sobre a parentalidade, parece que ainda não reuni elementos suficientes para asseverar que não se trata de resistir ao neologismo "parentalidade" em nome da transmissão da família em sua condição de resíduo. A seguinte pergunta ainda permanece: a parentalidade implicaria um risco para que haja um amanhã no qual a transmissão familiar, com suas falhas e imperfeições, continue vigorando?

A partir do exame das origens e dos discursos subjacentes à noção de parentalidade, proponho que o neologismo parentalidade possa ser lido como sintomático desta época, como um dos modos de sutura da falta prevalentes neste momento histórico, no qual o impulso de corrigir as imperfeições da civilização se edifica visando corrigir as imperfeições da transmissão parental. Da mesma maneira, penso que é possível ler as comunidades alternativas idealizadas em 68 como sintomáticas daquela época ${ }^{123}$, como veremos no próximo capítulo. Os discursos normativos e ortopédicos sobre a parentalidade comportam um ideal: investem na figura de pais competentes, implicados em um modo de vida voltado à educação das crianças e despojados dos dramas que a família comporta. Esta, ao assumir essa vertente da "parentalidade", se veria livre dos excessos e também das faltas ${ }^{124}$ ou imperfeições inerentes à transmissão. Se na família a

\footnotetext{
123 O famoso grito de André Gide:"Família, odeio-vos!", retomado pelos estudantes de 68, estaria nas entranhas das tentativas de se prescindir da família.

${ }^{124}$ Sofremos na atualidade, de uma maneira geral, de falta (déficit) ou excesso? Vivemos sob os desígnios da ausência de referências ou pelo seu excesso? Esse é um ponto importante porque no campo da família atribui-se um certo peso à falta, à deficiência, à carência, mas, ao mesmo tempo, pode-se fazer uma
} 
dimensão de gozo comparece (embora se espere que compareça de forma velada), nessa vertente da parentalidade pretende-se omitir o gozo inerente à constituição familiar. A aposta na desdramatização pode acarretar uma higienização da família, mais um traço a ser destacado desta época em sua intolerância ao sintoma, marcada pela pretensão de desembaraçar-se do real.

Forget (2007) lembra outros termos que comparecem no discurso social e que viriam juntar-se à parentalidade como modos de sutura da falta de nossa época, termos ${ }^{125}$ esses que têm em comum a aspiração de elidir a falta e a contradição. Além do termo parentalidade, o autor relaciona o termo paridade, quando se propõe a substituir homem e mulher, e "os direitos da criança", quando substitui a criança como fruto da falta e do sexual. Eu acrescentaria que tais termos são muitas vezes utilizados com a pretensão de excluir a disparidade de lugares, que é estrutural e que se radicaliza no irredutível da diferença entre os sexos (e que, como vimos, não deve ser confundida com o modo pelo qual ficções jurídicas estabelecem a divisão da autoridade entre pai e mãe e, tampouco, à diferença entre os genitais masculino e feminino).

É importante ressaltar que o discurso social se constrói como uma categoria coletiva, dá aos termos uma aparência de homogeneidade ${ }^{126}$, permitindo atribuir-lhes predicados universalizadores, como "as crianças de hoje", "os pais de hoje", etc, e organizando os indivíduos em categorias. É dessa forma que convida à submissão a um S1 coletivo e anônimo: existem "bons pais", desde que suas vidas sejam orientadas a partir das crianças e nas competências e habilidades estabelecidas a partir do discurso da ciência e veiculadas pelo "especialista da subjetividade". Vale lembrar que minha crítica não recai sobre a presença de categorias no discurso social, mas sobre a normatização e a prescrição de regras intrínsecas ao que nomeio nesta pesquisa discursos normativos e ortopédicos sobre a parentalidade.

leitura do que ocorre pela via do excesso: uma criança se retrai no encontro com o Outro porque este é deficitário ou excessivo? Uma família deixa suas marcas em seus filhos somente pela via da deficiência ou também por meio do excesso? Ler os fenômenos de uma forma geral pela via da carência (do pai, por exemplo) é, no mínimo, superficial e equivocado.

${ }^{125}$ É importante notar que, tanto quando faço referência à paridade como quando me refiro aos "direitos da criança", introduzo na sequência o advérbio "quando" com o intuito de assinalar que critico um uso específico destes termos e não sua legitimidade.

${ }^{126}$ Freud, em Psicologia das massas e análise do eu, texto de 1923, já advertia sobre os efeitos do empuxo à homogeneização. 
Neste ponto, é preciso retomar a discussão realizada no capítulo 2 sobre as articulações possíveis entre o sujeito e os modos de laço social predominantes em cada época. $\mathrm{O}$ discurso social refere-se aos efeitos do discurso do mestre que a modernidade isola como fatos de estudo e objeto sociológico. Vale pontuar que o discurso do mestre pretende que tudo funcione por homogeneização e sem tropeços, "[...] seu fim, é que as coisas caminhem no passo de todo o mundo" (LACAN, 1974, p. 9). O sintoma, por sua vez, faz objeção ao discurso do mestre (desejo que ça marche), uma vez que é o que faz desordem; é o que vem do real, o que comparece como um sinal de que algo não vai bem no campo do real.

Se, por um lado, o discurso social vale para muitos, por outro o sintoma constitui-se na singularidade. Vale marcar que é do laço social que o sujeito colhe elementos para fazer sintoma. Brousse (2010) é precisa ao pontuar a posição da psicanálise diante das transformações do discurso do mestre:

Ao formular que o discurso do inconsciente tem a mesma estrutura do discurso do mestre, Lacan põe a psicanálise em posição de analisar as transformações do discurso do mestre. Neste contexto, a orientação lacaniana permite pensar a evolução das práticas sociais, dos costumes, das mentalidades e do direito da família. É como dizer, em consequência, que a perspectiva conservadora ou reacionária que foi muitas vezes a da psicanálise, não pode ser a nossa, por razões lógicas (p. 142, tradução livre).

O sintoma social pode ser lido como estrutural, não se confunde com fenômenos particulares, ou com o que é relativo a uma época. É estrutural porque consiste naquilo que se formula diante do encontro com o impossível da relação sexual. Nesse sentido, pode-se ler a própria civilização como um sintoma social ao tentar regular a relação entre os sexos. Isso é o que permite afirmar que o sintoma social se atualiza nas respostas particulares formuladas em cada época diante da inexistência da relação sexual, ou seja, dos modos de sutura que cada época articula, o que venho nomeando como "sintomático de uma época". Essa articulação é coerente com o que Pujó (2006) apresenta como uma definição de época: "uma resposta específica e elaborada em determinado contexto histórico pela civilização, ao que Lacan formula como a ausência de relação sexual" (p. 62, tradução livre). 
Cada época articula um modo de resposta específica diante da inexistência da relação sexual. Nesta pesquisa, partindo da consistência que o neologismo parentalidade vem ganhando na atualidade, vi-me remetida a uma outra época, na qual o que aparece como sintomático é a pretensão de se prescindir das famílias (refiro-me ao fim da década de 60 e ao incremento das comunidades alternativas). Penso que esse neologismo não surgiu por acaso, mas justamente porque o que foi recusado em 68 retornou no real, numa consistência e pretensão de perfeição e assepsia que os discursos sobre a parentalidade parecem condensar. Vejam que, na atualidade, novamente é da família, ainda que lhe destacando outro traço (as faltas e imperfeições), que se pretende prescindir.

Isso posto, não pretendo fazer um estudo das respostas que cada época arma diante do confronto com a inexistência da relação sexual - isto nem seria possível -, mas destacar dois momentos na história em relação à família, justamente porque localizo neles uma certa relação: o que é recusado em 68, retorna como real na atualidade, evidenciando dois modos diferentes de sutura da falta, cada um deles condizente com o que se destaca em sua época como prevalente no laço social. Essa hipótese encontra seu alicerce no relato sobre as "crianças de 68" entrevistadas por Virginie Linhart, como veremos no capítulo 4.

Entendo a parentalidade como uma das versões da modificação atual do discurso do mestre, um dos modos de sutura da falta que se formula nesta época. A partir da psicanálise, no entanto, estamos advertidos de que a sutura não é um tratamento eficaz da falta e de que nenhum modo de sutura vai dar conta do que é da ordem do real, que sempre escapa.

É possível ler as mudanças sintomáticas que acontecem na clínica como efeito das mudanças ocorridas na civilização, entendidas como avatares da condição própria de falantes; ao mesmo tempo, é possível localizar os singulares modos de resposta que cada um elabora, no empenho de conservar sua singularidade. Outro modo de dizê-lo é que cada época e os modos de sutura da falta que engendra não são sem efeitos para o sujeito, contudo, a escolha é sempre deste. Reproduzo aqui a frase que abre o primeiro capítulo deste trabalho: "o sujeito é unicamente responsável pelo que ele faz de seus 
determinantes" (SAURET, 1998, p. 30). Bem, parece que vou reunindo elementos para consolidar a posição de que não se trata de proteger a família da parentalidade...

Uma publicação recente, datada de 2010 e intitulada Uniones del mismo sexo: diferencia, invención y sexuación, reúne psicanalistas lacanianos em torno do tema da parentalidade. Penso que até aqui fui preparando o terreno (ao situar sua origem histórica, os diferentes discursos que lhe são subjacentes, as políticas públicas, o contexto de mal-estar na atualidade ao qual se oferece como possível resposta, etc.) para formular uma posição psicanaliticamente consistente diante do cenário que o genérico "parentalidade" condensa. Além de marcar que assumo a posição de que a família resiste e de que não se trata de a psicanálise se anunciar como nostálgica, normatizadora ou entusiasta das novidades, também me posicionei diante dos psicanalistas que descrevem e analisam o cenário contemporâneo de forma mais pessimista ou catastrófica, ao marcar o mal-estar que é a civilização, o mal-estar que é a educação e ler os discursos e práticas que se organizam em torno da parentalidade como sintomáticos desta época. Ao atualizar as formulações de Laurent de que não se trata de recusar o que o contemporâneo arma em termos do "para todos", mas de reintroduzir o singular e legitimá-lo, vou delineando uma posição diante do campo de investigação ao qual me dediquei nos termos de reintroduzir a família na parentalidade. Daí todo o esforço empreendido no capítulo 1 não só de circunscrever a família na orientação lacaniana, mas de destacar sua função de resíduo.

Os artigos da coletânea que citei acima podem ser lidos como tendências, pontuações e interrogantes de psicanalistas de orientação lacaniana acerca do neologismo parentalidade, e foi a partir deste recorte que me deixei trabalhar por eles. Encontrei neles formulações como esta: "então, se esta invenção contemporânea promete a invenção de novos modos de paternidade, as conseqüências terão que ser verificadas. Em um futuro não tão distante, escutaremos nos consultórios estes filhos da "parentalidade" (NEGRI, 2010, p. 193, tradução livre). E até mesmo perguntas como estas: "Então, a psicanálise é possível para as novas famílias, para a atual parentalidade?" (TORRES, 2010, p. 175, tradução livre) ou "E aqui surge a preocupação, não só pelos objetos a que são hoje mais que nunca as crianças, mas - vou dizê-lo assim - a angústia pelo porvir, pelas consequiências nos sujeitos, nos filhos da parentalidade" (RUSSO, 2010, p. 211, tradução livre, grifo meu). 
Essas perguntas me fizeram lembrar do comentário de Laurent (2007) sobre uma época na qual se pensou não se poderem analisar filhos de pais separados! O encontro com a investigação empreendida por Virginie Linhart sobre as "crianças de 68" foi crucial para que eu pudesse me posicionar diante de enunciados como "os filhos da parentalidade". 


\title{
Capítulo 4 - Um "nós" que não existe
}

\begin{abstract}
"Minha mãe não parava de me explicar que nós, nós não nos interessamos por carros, mas por livros. Ela repetia sem parar que os livros eram bem melhores. E eu me lembro que aos cinco anos, eu pensava que ela estava errada [...]" (BARRET-KRIEGEL apud LINHART, 2008, p. 122).
\end{abstract}

Virginie Linhart acreditava que encontraria um "nós" ao entrevistar os adultos que, como ela, poderiam ser definidos a partir de um traço comum: "as crianças de 68". Filha de Robert Linhart, umas das figuras mais marcantes do movimento de 68 na França, Virginie conviveu 24 anos com o mutismo paterno ${ }^{127}$. Já adulta, iniciou o projeto denominado "uma pesquisa sobre o silêncio do pai". Seu livro $O$ dia em que me pai se calou $^{128}$ é a escrita deste processo.

Para significar o silêncio do pai, para dar conta de que "esta história não é só a sua história (do pai) é também a minha" (LINHART, 2008, p. 12), Virginie decidiu recorrer às crianças que, por terem sido submetidas aos ideais daquela época, formariam junto com ela um "nós": "as crianças de 68". Sustentada pela crença de que "atrás deles (os pais), há nós” (p. 27, grifo meu), decidiu entrevistá-las: "era a primeira vez que eu entrava um pouco na intimidade de outra criança de 68" (p. 27). Virginie pretendia falar ali onde seu pai se calou, mas para isso precisava que esses outros pudessem falar-lhe, precisava experimentar embaralhar-se em suas falas, o que - adianto já o final do livro habilitou-a a produzir um saber sobre o pai e permitiu que o silêncio daquele pudesse restabelecer-se, mas desta vez em outros termos. Quando seu pai se calou, seus familiares silenciaram acerca do silêncio dele, "[...] e nós, as crianças, fomos silenciosos sobre o silêncio" (p.112). Virginie via na decisão de romper o silêncio sobre o silêncio do pai - vejam que não se trata exatamente de romper o silêncio do pai - a possibilidade de pôr um fim à vergonha na qual seu mutismo a aprisionara.

\footnotetext{
${ }^{127}$ Virginie tinha 15 anos quando seu pai desapareceu subitamente de sua vida. Mais tarde, soube que ele esteve em coma durante semanas após a ingestão de uma dose massiva de medicamentos. Depois desse episódio seu pai permaneceria grande parte do tempo em silêncio.

${ }^{128}$ Título original: Le jour où mon père s'est tu.
} 
A premissa da qual Virginie parte é que a História (condensada nos ideais partilhados naquela época) teria determinado as histórias das "crianças de 68". Da mesma forma, atribui o silêncio do pai à queda daqueles ideais, ou seja, a uma decorrência de fatos historicamente determinados. Seu pai, segundo o que ela averiguou, foi uma das figuras mais marcantes daqueles anos, e infere: "infelizmente é umas das figuras mais marcadas" (LINHART, 2008, p.16). Trata-se de outro modo de dizer que as marcas que o fizeram calar-se decorreram da História: "Meu pai jamais se recuperou daquele tempo em que ele acreditou que seria possível infletir o curso da História” (p. 16). É possível reconhecer nessa hipótese inicial uma formulação sobre as articulações entre sujeito e sua época: o sujeito determinado por aquilo a que esta dava consistência.

Veremos adiante como naquela época, o "nós" se particularizara como um imperativo, fazendo-se valer mesmo que em detrimento do individual. O que a autora-protagonista não se permitiu supor é que entre o "nós" do discurso e "as crianças de 68" estaria o sujeito e sua singular amarração. No início de seu projeto, ela ainda não podia se perguntar a respeito da articulação entre a História, cujo rumo seu pai acreditava poder infletir e a historia de seu pai; não podia ainda localizar "um" decantado a partir do "nós" consistente no qual o pai (assim como os outros pais daquela época) estava imerso e que, supunha, o teria levado a calar-se. No entanto, em uma conversa com um colega de seu pai sobre o silêncio em que este se encerrara, Virginie afirma não saber o que teria decorrido das circunstâncias históricas e o que poderia ser imputado à problemática pessoal do pai. Ainda que ela afirme o pai como vítima da História, é sobre a história dele, sobre seu silêncio que se lança em sua pesquisa, intuindo ser necessário que um saber possa instituir-se para que o silêncio deixe de aprisioná-la.

O ponto de partida de Virginie foi o silêncio do pai; pretendia recolher nas outras “crianças de 68" traços a partir dos quais pudesse alinhavar a sua história, buscando produzir um saber ali onde o mutismo até então reinara. Se esse foi o ponto de partida, o método de pesquisa escolhido pela autora permite antever que o ponto de chegada lhe era desconhecido, e ela parecia disposta a suportar o que isso implicava. É a partir dessa posição que reconheço em Virginie uma pesquisadora. O uso do termo "método" aqui não é ingênuo, tampouco casual; pretende anunciar a discussão a seguir, a partir de meu encontro com o livro de Virginie, sobre como sua pesquisa me permitiu avançar e me 
posicionar nas articulações que venho propondo entre família, parentalidade e contexto histórico.

Em $O$ dia em que meu pai se calou, Virginie identifica furos em suas proposições, sujeita-se a inflexões, consente em abandonar as hipóteses formuladas inicialmente. Não é a partir dessa posição que surgem os "achados" ${ }^{129}$ ? A autora não só afirma não ter a pretensão de esgotar o tema ou realizar um estudo sociológico como explicita trabalhar a partir da associação de ideias, das lembranças perdidas que retornam, do encontro inesperado. Esse é seu método de pesquisa, um método que se aproxima do método psicanalítico.

Foi o encontro ${ }^{130}$ com a pesquisa empreendida por Virginie e o fato de, tendo partido do enunciado "as crianças de 68", dispor-se a colocá-lo à prova com cada um de seus entrevistados e sua singular amarração que me permitiram construir uma posição diante do enunciado "os filhos da parentalidade", precipitando-me numa possível formulação sobre como se articulam família, parentalidade e contexto histórico: não existe um "nós" passível de definir o conjunto das crianças nascidas em determinada época, mesmo que possamos localizar traços comuns entre elas. Essa formulação, penso, é o que decanta como um dos "achados" de Virginie.

\section{1 - A pesquisa de Virginie}

Logo no início de seu livro a escritora enunciou que decidira, em sua empreitada, entrevistar "as crianças de 68". Esse enunciado chamou-me particularmente a atenção: estaria rumando, em minha pesquisa, em direção a uma formulação semelhante? Autorizaria essa pesquisa enunciados como "os filhos da parentalidade"? Lanço a pergunta e prossigo, para retomá-la mais adiante.

Virginie partiu de um "nós", "as crianças de 68", mas escutou seus entrevistados um a um, endereçou-lhes suas hipóteses, verificou como podiam ou não fazer frente às perguntas que eram suas, testou a elasticidade, a resistência, o alcance e os limites de

\footnotetext{
${ }^{129}$ Referência à posição assumida por Lacan no seminário 11, a partir da frase de Picasso: "Eu não procuro, eu acho", na qual denota que não está à procura da verdade.

${ }^{130}$ Encontro possível graças à indicação preciosa de Caterina Koltai no exame de qualificação, a Laura Hansen que me emprestou o livro, e a Mariana Neustein que me enviou um exemplar.
} 
sua teoria. O dia em que meu pai se calou, dessa forma, não comparece aqui como ilustrativo de uma teoria ou modelar ${ }^{131}$ desta, mas como uma construção ancorada na disposição de colocar à prova uma tese, a existência de um "nós", referente aos modos de sutura da falta prevalentes em uma época determinada, enunciado como "as crianças de 68" A pesquisa de Virginie a levou a deixar cair o "nós" em benefício do um, não sem primeiro alienar-se em seus semelhantes e embrenhar-se em suas histórias. Paralelamente (veremos que, enquanto a autora procura e entrevista "as crianças de 68", seu pai subitamente rompe o silêncio em que se encerrou e volta a falar) foi levada à assunção de uma verdade: seu pai escolhera o silêncio. Com isso, não pode mais definilo e se relacionar com ele como vítima da História.

Lembrando do artigo de Cabral (2006), penso que, no caso de Virginie, a História estava a serviço de proteger a história ${ }^{132}$. Reproduzo a seguir um trecho desse autor com o intuito de justificar a afirmação: "É na cura analítica que reconhecemos um dispositivo genuíno de proteção da história ( contém, como veremos adiante, de empuxo à realização do próprio ser, diante da pressão uniformizadora da História do Outro" (p. 125, tradução livre, grifo meu). Virginie protegia-se de sua história alienando-se nas "crianças de 68", pagando com a repetição - na insistência com que o interesse pela política e pela história comparecia em sua vida, em seu trabalho, enunciada por ela como: "não consigo sair delas ou sempre volto para elas" (LINHART, 2008, p. 27) - a impossibilidade de separar-se da História e do Outro. Ao grifar um pequeno trecho da citação acima, destaco que outros dispositivos, como a escrita, a produção artística e até mesmo a produção acadêmica, podem ter efeitos subjetivantes e podem possibilitar a "realização" da história.

Se, no que se refere à articulação entre família, parentalidade e contexto histórico, a pesquisa de Virginie é tomada neste trabalho, infletindo seu rumo, devido ao espanto causado diante da consistência implícita em seu enunciado "as crianças de 68", desejo

\footnotetext{
${ }^{131}$ Souza (1994), em um trabalho de uma precisão digna de nota, ao circunscrever o que é um caso na psicanálise, alerta para os riscos de este comparecer como o leito de Procusto: o que sobra é cortado, e o que falta se estica até o limite da cama. Refere-se a uma na intervenção artística realizada por Tula Agnostopoulos em junho de 1998, "Small Size" na qual a artista mandou baixar o teto da sala na exata dimensão de sua altura: "O mundo daquele espaço de exposição se conformava à medida de sua estatura. $\mathrm{O}$ narcisismo de 1 metro e $53 \mathrm{~cm}$ organizando o espaço. $\mathrm{O}$ visitante, conseqüentemente, tinha que se curvar à altura da artista. Acredito que assim Tula conseguia dar visibilidade a uma construção que fazemos quotidianamente sem necessariamente nos darmos conta".

${ }^{132}$ Autor citado no capítulo 2.
} 
também tomá-la pela via do silêncio do pai, agora sim como ilustrativa do modo como o pai Real opera, conforme fundamentado no capítulo 1.

Dessa forma, a pesquisa de Virginie é aqui examinada por meio de duas vertentes: a da pesquisa sobre "as crianças de 68 " e a da construção singular, a qual não prescinde da outra, que esse processo lhe permite armar no que diz respeito ao pai.

Iniciei essa pesquisa mobilizada pelo mal-estar que me causava a consistência crescente dos discursos em torno da parentalidade no campo social, mais especificamente no terreno da educação, mas também no interior da psicanálise. Contudo, me encontrava em um impasse; eu explicitara os aspectos que não seriam tratados nesta pesquisa ${ }^{133}$ (no início do capítulo 2) esperando mostrar ao leitor que estava advertida em relação aos riscos de se buscar prever ou antecipar o futuro da família, pretendendo distanciar-me de posicionamentos preditivos, alarmistas e normativos. Entretanto, cada um desses aspectos e os riscos que implicam pareciam estar à espreita, tornando turvo o campo de pesquisa, estendendo o momento de compreender. Vale recorrer ao dicionário e à definição de impasse ${ }^{134}$ : "situação aparentemente sem solução favorável", "beco sem saída". Diante da temática da família e da parentalidade, avalio que o impasse se produz quando esta é apresentada como necessariamente aniquiladora da família em sua condição de resíduo, implicando um risco para as crianças, para "os filhos da parentalidade”.

$\mathrm{O}$ encontro com Virginie me permitiu evitar o risco de recair em modos genéricos ou universalizantes de compreensão - que autorizariam enunciados como: "os pais na atualidade", "as crianças contemporâneas", etc. - aos quais esse tema é particularmente sensível. Permitiu também evitar outro risco, que é a impotência para a qual o impossível, ao ser enunciado no terreno da educação, frequentemente nos arrasta, assim como a possível identificação com os autores que, ancorados também nas mudanças no campo da família, prenunciam um futuro dramático para o sujeito. Vale explicitar a que me refiro quando observo o que ocorre no terreno da educação quando o impossível é

\footnotetext{
${ }^{133}$ Reproduzo a seguir os aspectos em questão: definir os rumos que a família deve tomar, promover um alarmismo em relação às mudanças no campo da família, antecipar ou de traçar um veredicto sobre o que será das crianças educadas nas novas configurações familiares e compactuar com uma psicanálise que se apresenta como guardiã da moral e dos bons costumes.

${ }^{134}$ Fonte: Dicionário Aulete. Disponível no endereço eletrônico: http://aulete.uol.com.br/site.php?mdl=aulete_digital
} 
enunciado: reiteradamente surgem, por parte de professores e educadores, queixas em relação às famílias, à falta de recursos ou de formação específica ou à sobrecarga decorrente da inadequação das famílias. Nestes casos, o espaço que se abre diante do impossível, ao invés de produzir respostas particulares, passíveis de serem aplicadas no caso a caso, ou de habilitar a invenção, como se espera, produz impotência, queixa e desimplicação.

Tocar na diferença entre impotência e impossível é tocar nos efeitos do encontro com a inconsistência do Outro. "A incompleteza do Outro pode deixar o sujeito na via da impotência; o Outro não é capaz de me ajudar a 'sair dessa', de dar a resposta ou a interpretação que me ajudariam a me sentir melhor" (SAURET, 1998, p. 83). Ao mesmo tempo, a inconsistência do Outro, se tomada em sua vertente de impossível, pode consistir no fim da possibilidade de se recorrer ao Outro para solucionar ou regular a sua relação com o gozo. Penso ser possível afirmar que, ao deixar cair o "nós", Virginie abriu mão da impotência diante do silêncio do pai e constatou o modo singular (e inconsistente) deste de regular sua relação com o gozo. Penso ser disso que se trata o encontro com o pai Real, no caso de Virginie, capaz de autorizá-la a assumir uma relação confiável com o gozo, com o seu (dela) singular modo de gozo, abandonando definitivamente a História e depois o "nós", como determinantes da história subjetiva.

Embaralhando-se em cada lembrança - ou em cada modo de atualização presente do passado - de seus entrevistados, mas surpresa por não encontrar nestes um "nós", Virginie se permitiu submeter suas hipóteses à prova; não sem susto ou sem surpresa, não sem até mesmo mostrar alguma insistência.

A primeira "criança de 68" que Virginie encontrou foi Samuel Castro. Ela investigava o modo como aquele período o marcou. Samuel lhe disse que a política não o interessava; mais que isso, lhe era praticamente estrangeira, e ficou surpreso com o fato de que o trabalho de Virginie consistir em realizar documentários políticos e históricos. Perguntou-lhe se ela não estava farta dessas histórias. Sim, disse ela, mas “[...] não consigo sair delas ou sempre volto para elas" (LINHART, 2008, p. 27). O encontro com Samuel provocou-lhe espanto: "Acho surpreendente que efetivamente Samuel não saiba nada desta história que eu domino perfeitamente. Então é possível escapar. E o amor filial não tem nada a ver [com isso]" (p. 27, grifo meu). 
Didier-Weill (1997) descreve o ato interior por meio do qual alguém se deixa espantar como um reconhecimento que permite dizer um "sim", diferenciando-o de um constrangimento ao qual não se pode resistir. $O$ espanto diz respeito a um consentimento interior a uma presença outra, estranha, diante da qual se descobre, não sem surpresa, que não é estranha. A que estaria Virginie dizendo "sim"? Parece que à possibilidade de escapar, escapar sem que isso necessariamente abalasse o amor filial. Retornarei a este ponto mais adiante.

O tema do espanto e sua relação com o estranho é tratado por Freud em $O$ estranho, texto de 1919. O autor observa inicialmente que o estranho causa espanto precisamente porque não é conhecido, familiar. No entanto, no decorrer do texto, detecta a existência de uma certa intimidade entre o estranho e o familiar e é levado a definir aquele como algo que deveria ter ficado oculto (reprimido) e se manifestou. Em Recordar, repetir $e$ elaborar, esse saber não sabido involucrado no estranho já não passava despercebido por Freud: "Quando o paciente fala deste material 'esquecido', raramente deixa de acrescentar: 'Na verdade, sempre soube perfeitamente todas estas coisas; o que acontece é que nunca me detive para pensar nelas"” (FREUD, 1914, p. 1684, tradução livre). Estranho e familiar parecem consistir em duas faces da mesma moeda, de modo que um não existe sem o outro, ainda que essa relação não seja percebida de forma clara ou explícita na experiência. É nisto que reside o espanto: na revelação dessa intimidade surpreendente entre o familiar e o estranho.

Tal como é trabalhado por Didier-Weill, o espanto parece consistir na faceta "produtiva ${ }^{135 "}$ do encontro do que é familiar no estranho. Segundo o autor, o espanto tem o poder de introduzir uma descontinuidade no saber: "seremos assim levados a interpretar o espanto como o efeito de uma destituição subjetiva produzida por um significante especial [...]" (1997, p. 17). Esse significante é traduzido por Marie Bonaparte, em $O$ chiste e suas relações com o inconsciente, como "significante siderante". O espanto, dessa forma, não só produziria uma descontinuidade como também um furo no saber, tendo um efeito interpretativo para o sujeito. "Essa

\footnotetext{
${ }^{135} \mathrm{O}$ autor observa que o supereu tende a inabilitar a aptidão do homem ao espanto, levando-o a decair no já conhecido, em uma dimensão repetitiva do déjà-vu (DIDIER-WEILL, 1997, p. 29).
} 
interpretação vinda de meu adversário ${ }^{136}$ extrai seu poder do desejo muito particular que o anima" (DIDIER-WEILL, 1997, p, 20, grifo meu).

O efeito interpretativo do espanto é causado precisamente porque a relação do outro com o desejo está estruturada de forma diferente da minha. Parece que esse primeiro encontro de Virginie a fez deparar-se com o "há um", no lugar do "existe um nós" esperado. Seguindo com Didier-Weill, tal efeito só é possível porque havia, do lado de Virginie, a possibilidade de consentir, de deixar-se siderar, e porque, do lado do outro, se ele foi capaz de siderá-la, é porque compareceu a partir do singular desejo que o anima. O espanto arrancou Virginie do determinismo histórico: "então é possível escapar!"; entrou em jogo um saber não sabido, um saber que caiu como estranhamente familiar, embora se tratasse de um saber que já a habitava. E, bem, ao enunciar que "o amor filial não tem nada a ver [com isso]" ela deixava entrever que estava disposta a abrir mão da posição assumida diante dos pais e da herança familiar de que amá-los corresponderia a deixar-se aprisionar nos seus significantes ou no seu silêncio. Assim, quando a segunda frase de Virginie retroagiu à primeira, percebemos que ela não só foi compelida a abandonar a determinação histórica como também a hipótese da existência de uma linearidade ou um assujeitamento à herança familiar.

De acordo com Silva (2011), uma pesquisa se consolida com a sucessão de três tempos: o estranhamento, o entranhamento e o desentranhamento. É inevitável a lembrança dos três momentos lógicos formalizados por Lacan: o instante de ver, o momento de compreender e o tempo de concluir. A formulação de Silva, ao contrário da de Lacan, que está ancorada na lógica, remete ao que há de visceral nesse processo - parece que se trata mesmo de revolver as entranhas -, mas aponta também para a crucialidade de um terceiro momento, em que é preciso concluir, desentranhar-se. O terceiro tempo, diz Lacan, deve ser precipitado. Neste ponto, ao introduzir o tema da pressa, o psicanalista vem nos socorrer, porque uma pesquisa que se detém nos dois primeiros tempos propostos por Silva permanece em uma suspensão; entretanto, passar ao terceiro tempo requer um precipitador. No espanto, parece residir a condição para a precipitação de um

\footnotetext{
${ }^{136} \mathrm{O}$ autor toma como exemplo os jogos que são regidos pela bola: "Como dar conta do poder que essa pequena bola detém sobre milhares de seres humanos que, no estádio ou pela televisão, acompanham horas a fio suas idas e vindas? Qual é a natureza do espanto provocado cada vez que a bola desorienta suficientemente um dos jogadores para que ele a deixe passar?" (Didier Weill, 1997, p. 18).
} 
saber, ele comparece, dessa forma, como um disparador da pressa em sua função de uma certeza antecipada que, em ato, precipita uma conclusão.

Virginie experimentou o estranhamento cada vez que a singularidade se impôs e fez obstáculo ao "nós", mas suportou deixar-se furar em proveito do um. Ao entranhar-se na vida das outras "crianças de 68", ela caiu como um, mesmo que sua pesquisa nos permita confirmar que é possível destacar, no discurso social, traços que se particularizam como modos de sutura da falta prevalentes em uma determinada época, como vimos no capítulo 3.

Em O tempo lógico e a asserção de certeza antecipada, Lacan afirma que "o que as moções suspensas denunciam não é o que os sujeitos vêem, mas o que eles descobriram positivamente por aquilo que não veem [...]" (1945, p. 203). Acrescenta que a instância do tempo se apresenta de modo diferente em cada um desses três momentos, subsistindo apenas o último que os absorve. Vidal (2006) observa que a função da pressa já fora acentuada por Lacan em seu escrito sobre o estágio do espelho ${ }^{137}$, no qual descrevia a precipitação da criança da insuficiência à antecipação: "Tentando suturar a hiância entre a experiência que tem do corpo e a forma ideal percebida no espelho, a criança se precipita numa identificação com um objeto - a imagem do outro - que toma emprestado do Outro" (VIDAL, 2006, p. 3).

O momento de compreender opera em uma dialética com os outros dois tempos lógicos: "E também que se, nessa corrida pela verdade, é apenas sozinho, não sendo todos, que se atinge o verdadeiro, ninguém o atinge, no entanto, a não ser através dos outros" (LACAN, 1945, p. 212). Pois bem, se não existe o "nós" postulado por Virginie, isso não implica em uma negação do outro como semelhante, ao contrário, não há um sem os outros. O título do texto de Vidal citado acima parece também vir ao encontro da tensão que se estabelece entre o Um e os outros: Em tempo: sozinho, mas não sem os outros. O autor relembra a peça de Sartre datada de 1944, As portas fechadas (Huis Clos) na qual cada um dos três personagens, incapaz de perceber as próprias falhas, atribui-as aos outros dois, concluindo que "o inferno são os outros"; ao que Lévi-Strauss

\footnotetext{
${ }^{137}$ C.f. - LACAN, J. O estádio do espelho como formador da função do eu. In: Escritos. Rio de Janeiro: Jorge Zahar editor, 1998, p. 100.
} 
teria retrucado: "o inferno é cada um". No caso dos três prisioneiros, "o sujeito atinge sozinho o verdadeiro, mas não o faz sem os outros, numa operação que deixa resto" (VIDAL, 2006, p. 4).

Em sua pesquisa, Virginie não pretendia retratar fatos históricos, ordená-los ou verificálos, mas escutar seus entrevistados, estranhando-se e emaranhando-se em suas histórias.

Vale retomar como Lacan explicita os limites entre realidade e verdade em Função $e$ Campo da palavra, lembrando que, na análise, não se trata da realidade, mas do modo como passado e futuro podem conjugar-se na história de um sujeito. Virginie escolheu alinhavar, reunir, escandir as suas lembranças e as lembranças de cada um que encontrou, menos a partir do modo como elas procediam informativamente do que a partir do lugar exato em que se apoderou de cada uma delas. Trata-se de uma construção (SOUSA, 1994). É assim que tomo O dia em que meu pai se calou como uma construção; uma construção que não só interpela a teoria, mas que também revela as sinuosidades do campo conceitual no qual se transita (SOUSA, 1994).

A leitura do texto de Virginie me levou a definitivamente a abandonar perguntas na linha de: “o que será dos filhos da parentalidade?" Levou-me inclusive a recusar a premissa de que haveria "filhos da parentalidade", reafirmando o imponderável que opera em cada época, no encontro da transmissão - do lugar em que uma criança foi desejada, do gozo que condensou - e da ficção que cada uma inventa para si, nesse encontro. Em cada entrevista com Linhart, a "criança de 68" em questão permite acompanharmos sua solução singular diante do que prevalecia no laço social daquela época, evidenciando que os traços de uma época são particulares e não singulares, que o modo como pai e mãe são tocados por esses traços é singular, assim como é também singular a construção de cada um. Nesse sentido, o Outro pode ser decisivo, mas é o sujeito quem decide!

Sauret (1998), ao reunir uma série de textos para a publicação de seu livro $O$ infantil e a estrutura, reconhece que podemos ser contados pelo que escrevemos. A leitura de $O$ dia em que meu pai se calou me permitiu atualizar a afirmação de Sauret nos seguintes termos: podemos também contar-nos a partir do que escrevemos. Em seu relato, ao arrancar-se da determinação histórica, Virginie deixou de acreditar que poderia ser 
contada (pela História, pelos outros) e pôde contar-se como uma (entre outros), não sem reconhecer, ao mesmo tempo, o um em seu pai.

\section{2 - "As crianças de 68"}

No belo relato de Virginie, nota-se que ao encontrar cada criança de 68, ela encontrou algo de si; seu discurso ia e voltava a partir dos discursos dos "outros", de modo que muitas vezes não sabemos quem fala, e, quase sempre que isso acontecia, acabamos por verificar que era Virginie. Ela falava a partir dos outros, em um movimento dialético que ia de si a eles e deles para si novamente: "Explorando as lembranças deles surgem as minhas. Sem eles, eu não posso nada. Suas narrativas liberam minha palavra" (LINHART, 2008, p. 33).

Entrevistar "as crianças de 68" foi para Virginie também entrevistar-se, precisou falar dos outros para poder falar de si. A autora-protagonista se confundia inicialmente com os outros nos quais precisou alienar-se para, depois, separar-se. Mas Virginie também encontrou traços comuns em seus entrevistados, localizados por eles a partir de como o "nós" se impunha naqueles tempos, prevalecendo sobre o indivíduo. Situar estes traços é fundamental para entender o mandato a partir do qual as "crianças de 68" responderam ao se converterem em pais: não reproduzir aquilo que seus próprios pais fizeram, o que implicou ordenar suas vidas em torno dos filhos.

Esse mandato é enunciado por uma das entrevistadas, Lamiel Barret-Kriegel: "É impressionante a distância entre a maneira pela qual nós fomos criados e a maneira pela qual nos ocupamos de nossas crianças. Também, eu não passo um dia sem que me diga: lembrar a cada dia de não fazer o que os meus pais fizeram comigo" (LINHART, 2008, p.29). Também por Claudia Senik: "na vida cotidiana, com meus filhos, eu estou na antípoda do que eu vivi com meus pais" (p. 107); ou, ainda, por Juliette Senik: "mas a diferença fundamental entre a educação que eu recebi e a dos meus filhos, é que nossos pais faziam a sua vida e nós os seguíamos, enquanto eu me curvo ao cronograma de meus filhos" (p. 128). Ao longo do livro, os entrevistados de Virginie apresentam, cada um à sua maneira, o modo pelo qual a parentalidade converteu-se em um modo de vida para eles. 
A crença em um "nós" não era apenas um sonho de Virginie, era quase uma consequiência lógica do modo como o "nós" era vivido naquele tempo por seus pais e outros militantes: como um imperativo. Embora não se trate nesse trabalho de fazer um estudo sobre aquela época, faz-se necessário situar que a que me refiro quando falo em um "nós" consolidado pela militância política de esquerda. Conforme observa ReyFlaud, 2002: “A vontade de uma uniformização dos indivíduos manifestada pela revolução cultural maoísta se inscreve nesta tendência a apagar as diferenças no interior do grupo ao fazer a diferença passar por fora (pelo espaço maldito do capitalismo)" (p. 43).

Assim, o "nós" que se consumaria nas "crianças de 68" pode ser lido como um coletivo imaginário $^{138}$, fundado numa propriedade supostamente preexistente, que poderia ser formulada da seguinte forma: as crianças cujos pais estavam submetidos aos mesmos ideais, forjados a partir de um "nós" consistente, sustentado pela militância política de esquerda. Essa hipótese não só implica uma supervalorização da História em detrimento do sujeito como também não leva em conta os modos pelos quais cada família singulariza o que prevalece no discurso social, o gozo que cada um, pai e mãe, testemunha na transmissão e a ficção, singular, que cada criança arma para si nesse cenário. Pode-se então afirmar que naquela época a militância comparecia como um modo de vida ${ }^{139}$ ? Se em sua base estava a exaltação do "nós", mesmo que em detrimento do individual, pode-se também reconhecer nela um modo de sutura da falta ou uma ilusão de harmonia, como diria Freud - articulado àquela época?

O pai de Virginie era maoísta. O modo como o "nós" se condensava naquela época é definido quase de forma caricaturesca no livro de Zuenir Ventura 1968: O ano que não terminou. $\mathrm{O}$ autor relata a queixa de Nelson Rodrigues, impactado pelo modo como o indivíduo perdia o contorno nas assembléias e passeatas, de não poder mais saudar um artista por este ter se tornado um ser impessoal, coletivo: "Não era um ator, era um Discurso, era uma Comissão, era uma Assembléia. Dizia 'nós' e não 'eu'” (RODRIGUES apud VENTURA, 2008a, p. 76).

\footnotetext{
${ }^{138}$ François Geismar, umas das "crianças de 68 " entrevistadas por Virginie, recusa a existência de um "nós", diz ser imaginário esse coletivo e não acredita ter algo em comum com as outras "crianças de 68". ${ }^{139}$ A militância é abordada como sintomática de uma época em FIGUEIREDO, L. C. (1995) Modos de subjetivação no Brasil e outros escritos. São Paulo: Escuta/Educ.
} 
Em um trecho de seu segundo livro 1968, o que fizemos de nós, Ventura (2008b) capta com precisão o modo pelo qual o "nós" se impunha naquela época. Mostra a definição do Juiz Eros Grau, em seu romance Triângulo no ponto, para a diferença entre um militante e os outros cidadãos, a partir do seguinte evento: ao serem informados acerca do $\mathrm{AI}-5^{140}$, dois amigos preocupam-se com a sociedade como um todo enquanto o terceiro preocupa-se com os riscos que corre pessoalmente devido aos "rastros" que deixara de sua militância política. Eros Grau é contundente: "em mim não predomina a singularidade. Acho que felizmente predomina o universal" (2008b, p. 54).

Creio que esta é a melhor definição que pude encontrar do modo pelo qual o "nós" se instituía sobre o individual naquela época. A militância se apresentava como uma renúncia a toda e qualquer "veleidade" individual. Virginie também retratou esse traço ao se referir a uma passagem do romance de Olivier Rolin, Tigre en papier - que traça a história dos militantes maoístas naqueles anos. Na passagem, uma moça demanda do narrador um testemunho sobre seu pai, de quando ela era uma criança. A resposta que recebe é esta:

Eu não posso te falar dele sem falar de nós. Não sei como te fazer compreender isso, nós não éramos "eu" naquela época. Isso se devia à nossa juventude, mas acima de tudo à época. $\mathrm{O}$ indivíduo nos parecia negligenciável e até mesmo menosprezável [...] sem nós, todas nossas memórias desaparecem (LINHART, 2008, p. 31).

Lamiel Barret- Kriegel descreve o modo como o "nós" se particularizava no discurso de seus pais: "Minha mãe não parava de me explicar que nós, nós não nos interessamos por carros, mas por livros. Ela repetia sem parar que os livros eram bem melhores. E eu me lembro que aos cinco anos, eu pensava que ela estava errada [...]” (p. 122). Então, se o "nós" comparecia como um imperativo, isso não quer dizer que todos se submetiam a ele de igual maneira. Thomas Piketty também sonhava com grandes carros, e seu pai lhe dizia: "sabe, Thomas, eles têm grandes carros, mas não têm belas ideias na cabeça" (p. 119). Em seu relato, Thomas não só acentua o peso do "nós" como também que a existência de um "nós" leva, invariavelmente a um "eles". Diante da contundência do

\footnotetext{
${ }^{140}$ O Ato Institucional n. 5 entrou em vigor em 13 de dezembro de 1968, durante o governo de Artur Costa e Silva. O AI-5 foi o quinto de uma série de decretos emitidos pelo regime militar brasileiro nos anos seguintes ao golpe militar de 1964; sobrepondo-se à Constituição, dava poderes extraordinários ao Presidente da República e suspendia várias garantias constitucionais.
} 
pai, Thomas pensava que ele poderia ter razão; todavia, aqueles carros eram realmente belos!

Nesse sentido, pode-se dizer que a militância política, além de se constituir em um modo de vida na juventude dos pais de Virginie, comparecia como um modo de sutura da falta predominante naquela época. Um dos "achados" dela foi, portanto, que uma época incide no laço social, e que, no âmbito da família, essa incidência comparece a partir de como o discurso social entende que as relações devem se estabelecer. Gavarini (2008) explicita isso da seguinte maneira: "A variabilidade das formas adotadas pelo grupo familiar e pela parentalidade mostra bem que a família e o fato de ser pais são diversamente instituídos segundo o período histórico e as sociedades" (p.2). O testemunho de Lamiel é preciso: passou a infância a seguir os pais, rodeada por adultos discutindo política ou cultura. Acredita que embora os pais não se interessassem pelas crianças como fazemos na atualidade, eles queriam transmitir-lhes sua ideia de cultura e conhecimento. Ela, por sua vez, se preocupa com o bem-estar e o desenvolvimento de seus filhos, concluindo: "Acredito que isso não estava ligado aos meus pais. Era a época!" (LINHART, 2008, p. 88, grifo meu).

O cenário que se organiza hoje em torno da família e da criança - a parentalidade alçada à condição de "modo de vida" - remonta àquilo que as "crianças de 68 " recusaram em seus próprios pais. Os traços que marcam uma época não são alheios àqueles que prevaleceram num tempo anterior; dito de outra maneira, os modos de sutura da falta de um determinado momento histórico retornam como o sintomático da época subsequente. Lamiel é precisa em seu relato porque enuncia o quanto aspectos como o bem-estar e o desenvolvimento estão atualmente no centro das preocupações da família, como decorrência do lugar no imaginário social que a criança e o exercício da parentalidade ocupam na atualidade.

Um aspecto que me chamou particularmente a atenção é que alguns dos entrevistados de Virginie leem como retorno ao que fora recalcado na época anterior o modo como seus pais se atiraram no movimento de 68. Observam que muitos dos que se destacaram naquele período eram judeus, filhos de judeus imigrantes. Seus avós tinham vergonha de ter sobrevivido ao holocausto e seus filhos e netos teriam sido criados como sobreviventes. Essa seria uma resposta possível à pergunta sobre o número altíssimo de 
judeus participantes do movimento de 68, ou seja, talvez estes tivessem visto naquele movimento a possibilidade de sair da condição de sobreviventes, a possibilidade de viver em contraposição a seus pais, que se permitiam apenas sobreviver.

O tema do "nós" é abordado por Lacan em sua análise do mito de Eros, e seu potencial devastador é marcado pelo psicanalista ao situá-lo na base da segregação. O mito de Eros, para Lacan, ao contrário do de Édipo, é perigoso, pois leva a confusões sobre o que é o Um ${ }^{141}$. No início do seminário 20, o autor aponta para a "confusão original" (p. 13) que o mito de Eros comporta ao "tender a fazer um só dessa multidão imensa" (1972-73, p. 72). Nesse mito, o Um seria o produto da fusão de dois, e sabemos que não há como dois fazerem $\mathrm{Um}^{142}$, “[...] em nenhum caso dois corpos não podem fazer um por mais que se abracem [...] De forma que não há nenhuma espécie de redução ao um" (Lacan, 1974, p. 31). O mito de Eros apontaria para a existência de Um da relação sexual.

Neste sentido, a formulação de Lacan do pai para além do Édipo como metáfora paterna pode ser tomada como uma nova abordagem sobre a questão do Um. Como vimos no capítulo 1, o pai Real, ao testemunhar um modo singular de gozo, surge como um pai, fazendo exceção para que a função possa tornar-se modelo. Opera não porque é excepcional, mas porque é único. Nessa perspectiva, os pais, um a um, dão testemunho de sua versão de gozo da função, fazendo exceção a toda e qualquer universalização. Para Lacan, só há universal do possível: “nós” só existe como possível em Um.

A predição de Lacan da ascensão da segregação é correlativa a esse apagamento da diferença em proveito da similitude: os mesmos com os mesmos. No discurso preconizado em 68 pela militância de esquerda, a face segregacionista do "nós" comparece sempre que a diferença passa por fora e ele mesmo se impõe, de forma autoritária e consistente. $\mathrm{O}$ trecho reproduzido acima sobre a uniformização no contexto

141 "Do que é que se trata então no amor? O amor, será que - como promove a psicanálise com uma audácia tanto mais incrível quanto isto mais vai contra toda a sua experiência, e quanto mais ela demonstra o contrário - o amor, será que é fazer um só? Eros, será ele a tensão para o Um?" (LACAN, 1972/73, p. 13).

${ }^{142}$ No Seminário 20 - Mais, ainda (1972/73), Lacan grafa Um (com letra maiúscula). O autor relata que a formulação Há Um deu suporte ao seu discurso do ano anterior (referência ao Seminário 19 ...Ou pior, 1971-72) aspirando a não recair nessa confusão entre o Um, suposto no mito de Eros, e o Há Um em hiância com o Outro, revelando a impossibilidade inerente à relação sexual. A representação deste Há Um é o nó borromeano. 
do maoísmo continua com a seguinte afirmação: "O racismo mantém o mesmo ódio da diferença em nome da in-diferença mantida entre os membros da comunidade" (REYFLAUD, 2002, p. 43). Nota-se que o autor identifica fenômenos como o racismo na mesma base do construto que justifica o "nós".

Pacheco (2009) também evidencia o que subjaz em potência na ilusão de um "nós":

Mais de um psicanalista já nos lembrou que os sujeitos com estrutura neurótica, inconformados com essa condição, constroem um saber coletivo que os assegure mutuamente da ilusão de que estão juntos na mesma fantasia e de que se remetem a um único e mesmo Outro absoluto e sem falhas. Eles se entregam como instrumentos desse saber, evitando indecisões, hesitações ou incertezas (p. 146).

Didier-Weill, em sua formulação sobre o espanto, localiza uma posição desfavorável a ele na identificação coletiva a um líder; há "um cuidado redobrado" (1997, p. 25) para que este não se manifeste, de modo que se opta por alienar-se ao outro "na figura sem surpresa do mesmo".

Essa discussão remete à análise empreendida por Freud em Psicologia das massas e análise do eu, na qual destaca a tendência existente, sempre que os homens se reúnem, de surgir "uma massa psicológica". O autor inicia a discussão destacando dois aspectos fundamentais no que se refere à relação do indivíduo com o social. O primeiro é que somente em circunstâncias excepcionais um indivíduo pode prescindir da relação com seus semelhantes e o segundo é que "a psicologia individual é ao mesmo tempo e desde o princípio uma psicologia social, em um sentido amplo, plenamente justificado" (FREUD, 1920/21, p. 2566, tradução livre). Partindo de perguntas como o que é uma massa e por que ela exerce tanta influência sobre o indivíduo, Freud examina as ideias de Gustave Le Bon sobre as massas.

Interessa-me destacar duas características das massas: a primeira é que a noção de impossível não existe para o indivíduo que faz parte de uma multidão; a segunda é que nas multidões o que se pede são ilusões, às quais não se pode renunciar. Penso que esses dois traços comparecem na ilusão de harmonia que em cada época, assume uma forma, um "nós", mas, neste caso, tanto o impossível como a ilusão não têm a mesma consistência que nas massas. Dessa forma, os fenômenos de massa podem ser lidos 
como uma das facetas pelas quais o "nós" comparece, como uma das formas de manifestação da potência subjacente à ilusão de um "nós", quando esta perde seu caráter de semblante.

Situar o "nós" como uma tendência no laço social evidencia seu caráter de ilusão (necessária para tolerar a condição humana, como vimos no capítulo 2), porém, como ilusão, não pode dispensar seu caráter de semblante, pode-se acreditar nela, mas não muito. Tolstoi, em sua famosa frase: "Todas as famílias felizes são parecidas; as infelizes o são cada uma à sua maneira" parecia estar já advertido dos riscos de se confiar em demasia na consistência de um "nós", conformando um enunciado que cabe como uma luva na atualidade. Explico-me: se na atualidade o que prevalece no discurso como ilusão é a felicidade para todos, na família esta se particulariza na busca pela competência e pela assepsia, aspectos destacados pela parentalidade ao assumir sua faceta normativa. Assim, como Tolstoi, aposto na singularidade das famílias infelizes, imperfeitas e faltosas, e lembro de Marçal Aquino, que, já no título de seu livro Famílias terrivelmente felizes, apresenta seu mal-estar diante de uma normalização da família.

Ainda investigando os fenômenos de massa, Freud constata que a neurose extrai o indivíduo das formações coletivas habituais, constituindo-se em um fator de desagregação: "o neurótico substitui as grandes formações coletivas por suas próprias formações sintomáticas" (FREUD, 1920/21, p. 2609, tradução livre). Essa observação cai como uma luva para mim! Eu a formularia da seguinte maneira: é o sujeito, com seu sintoma, com a singularidade do gozo ali engendrado, que faz objeção ao "nós" e também ao "para todos".

Com isso, parece que começo a delinear uma resposta para a pergunta formulada no final do capítulo 2: como localizar o que faz objeção ao universal e ao homogêneo condensado no "para todos" da parentalidade? É a família em sua função de resíduo (com suas faltas e imperfeições) que faz objeção à consistência intrínseca ao neologismo parentalidade, e é o sujeito (com seu sintoma) que faz objeção ao "nós", independente da forma que ele assume em cada época. Alcanço formular que o "nós" articulado em cada época, na ilusão de armar uma sutura à falta, não se confunde com o "para todos" produzido pelo discurso capitalista, evidenciado no laço social na 
aspiração à "globalização" e particularizado na família sob a forma da inevitabilidade do apoio (ou da intervenção) a todos os pais. Sustentando-se no discurso capitalista o "para todos" parece constituir-se em uma tentativa de superação do "nós" em prol do "todo". No entanto, que haja "uns" é constituinte da civilização.

O leitor atento, que vem me acompanhando nas formulações sobre os modos pelos quais o "nós" se atualiza no laço social, poderá se perguntar se a família também não se instituiria como um "nós". Diante desse interrogante, eu responderia que a família é também um coletivo social e que, em sua função de semblante, vela o impossível da relação sexual. Contudo, a noção da família como resíduo, ao operar a partir dos singulares modos de gozo que cada um, pai e mãe, testemunham na transmissão, faz objeção a essa consistência, furando-a.

Voltemos aos entrevistados de Virginie e aos seus testemunhos sobre como é possível escapar da consistência de um "nós". Mathias Weber, amante do rugby e filho de Henri Weber, testemunha uma hipótese sobre a transmissão diferente da de Virginie, destacando-lhe um traço: "eu e meu pai não temos a mesma paixão, mas a necessidade de investir em algo que nos apaixone" (LINHART, 2008,p. 156). Éve Miller, por sua vez, está certa de que sua mãe privilegiou a atenção às crianças em relação à vida militante. Lembra-se de um ambiente familiar estruturante com a presença de seu avô materno... o avô materno de Éve era nada menos do que Jacques Lacan! A psicanálise é referida em alguns trechos do livro, e destaco um que chamou particularmente a minha atenção: tanto Virginie como Lamiel mostram-se especialmente aliviadas por terem escapado da vida em comunidade e agradecidas por terem feito análise! Embora aparentemente não exista uma conexão entre esses fatos, tanto a oportunidade de fazer análise quanto o fato de ter escapado da vida em comunidade abriram para cada uma delas a possibilidade de realizar ou de proteger a construção de uma versão singular diante da consistência que o "nós" tinha naquela época.

O tema da vida em comunidade é complexo e requer um estudo mais aprofundado. No entanto, recorto um aspecto que me parece central para a discussão sobre as especificidades de cada época e sobre o modo como o neologismo parentalidade comparece na atualidade. René Levy viveu em comunidade e lembra-se de como era difícil para as crianças suportarem a liberdade de costumes: "A comunidade não é uma 
boa lembrança. São minhas primeiras lembranças de angústia” (LINHART, 2008, p. 52). Naquela época, portanto, a sexualidade não era velada na família, e Levy lembra que isso não é sem conseqüências para as crianças. Contudo, os relatos mostram que não só a liberdade sexual não tomava a mesma forma em todas as famílias como também que as crianças inventavam diferentes maneiras de fazer-lhe frente. Alexandra Roussopoulos escutava os pais conversarem em reuniões, de forma muito livre, sobre a vida em casal e sobre a sexualidade, mas não sabia nada da sexualidade deles ou de sua intimidade. Observa que os pais sempre tiveram o cuidado de preservá-la. Para Claudia Senik, "a liberdade sexual exuberante da qual foi espectadora quando criança" (p. 168) não resultou em dificuldades ou constrangimentos. Sua irmã, Juliette Senik, lembra-se de que, em vez de contar histórias de fadas, inventava histórias de amor entre adultos, "é preciso que isso possa sair de uma maneira ou de outra [...]" (p. 169). Já Virginie relata que, durante muito tempo, foi incapaz de emitir qualquer som durante as relações sexuais.

No que diz respeito ao modo como o tema da liberação sexual comparecia nas famílias, o testemunho de Julier Faguer é contundente: "A liberdade dos costumes, do casal, era infernal!” (p. 169) e acrescenta: "o problema é que uma criança não deve conhecer a sexualidade de seus pais" (p. 170, grifo meu). Eu acrescentaria: as crianças não devem conhecer a sexualidade de seus pais, mas devem desconfiar de que ela está ali. Acredito que esse é o exato ponto em que se situa a sexualidade como velada na família: recobre o que é da ordem do gozo, mas ao recobri-lo permite vislumbrar sua existência. Ao mesmo tempo em que são velados na família, os modos de gozo de pai e mãe velam a inexistência da relação sexual. O que chama a atenção é que na versão atual da família, que se apresentaria sob a forma da parentalidade ${ }^{143}$, novamente o gozo sexual não é velado, mas, desta vez (quando se passa a valorizar a técnica e a competência na transmissão, como se o fato de tornar-se pai ou mãe pudesse ser isolado do sujeito, de seus modos de gozo e de suas imperfeições) pretende-se extirpá-lo do cenário familiar. Pretende-se excluir o que é sexual do campo da família, como se realmente nela a transmissão pudesse se concretizar sem deixar nenhum resto. O que não se pode perder de vista é que na família, pai e mãe conformam-se em semblantes, velando o real e, como tal, respondem à inexistência da relação sexual, mas é fundamental que, ao

${ }^{143}$ Tomada em sua vertente normativa e ortopédica. 
assumirem suas funções, possam suportar, mas não consistir, vacilando entre o velamento e o inevitável desvelamento do real.

Quando a família se apresenta na forma de uma "parentalidade", inscrevendo-se em uma época em que o discurso da ciência prevalece, esquece-se de que pai e mãe são semblantes e estes passam a ter uma consistência, cindida da singularidade do desejo que produziu a criança. Na "parentalidade", a consistência dessas figuras passa a ser tamanha (pais que são habitados pela certeza e pela prometida assepsia na transmissão) que, o que está velado na família - a inexistência da relação sexual - pretende ser definitivamente extirpado do cenário familiar.

Assim como não existe um "nós" nas "crianças de 68", entendo que não haverá um "nós" nos filhos da parentalidade. Aliás, penso que a formulação "crianças de 68 " não tem fundamento dado que, mesmo que uma época ordene modos de sutura particulares, não há generalização possível: este "nós" não existe. O sujeito faz o "nós" não existir em sua articulação singular no seu sintoma. Virginie foi levada a constatar que não conformava um "nós" com seus entrevistados, mesmo que tenha precisado por um tempo perder-se em seus relatos, para separar-se e deixar-se cair como "uma". Ainda que o "nós" comparecesse como um imperativo naquela época, conformar-se em um "nós" junto com "as crianças de 68" parece ter sido um sonho de Virginie, a sua versão

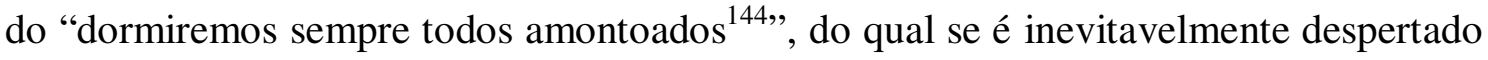
pela constatação de que somos habitados - e habilitados - pela separação, mesmo que não vivamos separados.

\section{3 - O silêncio do pai}

Virginie parece ter iniciado sua pesquisa em um momento de vida no qual estava disposta a deixar-se cair: como vítima da História, como compondo um "nós" com as outras crianças nascidas naquela época, como aprisionada no silêncio paterno. Foi nesse momento particular de sua vida que o espanto pôde siderá-la, espanto que compareceu em dois tempos: no encontro com Samuel Castro e no encontro com o que falar implicava para seu pai. Vale lembrar que o espanto traz um afeto como se fosse pela primeira vez, que não só este não é recebido como repetição como, ao fazer furo no

\footnotetext{
${ }^{144}$ Referência à discussão sobre o filme "Onde vivem os monstros”, realizada no capítulo 1 .
} 
saber, dá um basta naquela ${ }^{145}$. O espanto, dirá Didier-Weill, surge quando o sujeito é capaz de se autorizar dele mesmo, e eu acrescentaria: sem precisar alienar-se em um "nós" para sustentar-se, sem precisar aprisionar-se na História para apaziguar a vergonha. O pai saiu do silêncio justamente enquanto ela "descobria" que só existe "nós" a partir do um. Esse segundo espanto precipitou Virginie ao momento de concluir.

Era estranho que no momento em que eu me decidira finalmente a contar a historia de meu pai, para me liberar, em que eu me decidira contá-la precisamente por onde ela me havia feito sofrer - seu silêncio - não havia mais silêncio, o silêncio tinha desaparecido, meu pai recomeçou a falar! (LINHART, 2008, p. 190, tradução livre).

Quando finalmente Virginie decidira contar a história de seu pai para se liberar, seu pai sofre um acidente doméstico e, inesperadamente, voltou a falar. "agora é meu pai que fala, sem parar, com todo mundo, sobre tudo" (p. 192). Virginie observa que demorou para perceber os sinais de perigo: seu pai entrara em uma crise maníaca. Rapidamente a loucura se apoderara dele novamente. "Eu compreendi que ele foi para si mesmo até agora seu melhor médico. [...] Meu pai não era essa vítima que eu imaginei por tanto tempo, ele era um homem que sabia exatamente como se proteger de seus demônios e fez tudo para isso" (LINHART, 2008, p. 194, grifo meu).

Agora Virginie sabe por que seu pai se calou. Ele não estava na mesma problemática daqueles que continuaram a falar, a se expor publicamente, etc. "Na sua doença, ele demonstrou uma grande sabedoria. No seu isolamento, mostrou um domínio perfeito de seu destino" (p. 196). Agora sei por que meu pai escolheu se calar" (p. 197, grifo meu).

Em $O$ dia em que meu pai se calou, ao deixar cair o "nós", Virginie deixou cair a História como determinante de sua história, lá onde a história de seu pai era também a sua. Virginie se pôs a falar e, assim fazendo, encontrou em cada entrevistado uma solução única e que seu pai não foi exclusivamente uma vítima da História; sua queda, seu silêncio, descobrimos junto com ela no final, foi uma escolha, uma produção

\footnotetext{
${ }^{145}$ No seguinte trecho localizo em Lacan o modo pelo qual a história lhe interessa: "Com efeito, esse limite está presente a cada instante no que essa história tem de acabado. Ele representa o passado sob sua forma real, isto é, não o passado físico, cuja existência é abolida, nem o passado épico, tal como se aperfeiçoou na obra da memória, nem o passado histórico em que o homem encontra o garante de seu futuro, mas o passado que se manifesta revertido na repetição" (LACAN, 1953c, p. 319).
} 
singular, e, portanto, uma produção da ordem da exceção, o que, já sabemos, pode dar lugar a outras exceções. Indo um pouco mais longe, proponho que, ao reconhecer no silêncio do pai uma saída singular, não apenas tributária da História, ainda que certamente carregada pelos traços que a marcaram, Virginie pôde exceder o "nós".

O pai de Virginie era descrito por seus companheiros como "excepcional”. No capítulo 1, adverti para os riscos de um pai que ocupa o lugar de excepcional, porque neste caso, não estaríamos diante de um pai que faz exceção testemunhando um modo de gozo singular, mas daquele que se apresenta e se acredita como ideal, como despido de imperfeições. Virginie parecia estar aprisionada em uma báscula que ia do pai excepcional ao pai envergonhado; a interrupção do silêncio deste e a emergência de sua loucura habilitaram-na a significar sua história a partir de outras coordenadas. Vejam que o pai Real, este que se descortina para Virginie, um pai maníaco, não se confunde com um pai ideal. O pai calado, silenciado pela História, um pai morto, este sim estaria mais sujeito às idealizações, mais passível de ser salvo, ainda que ao preço de ver-se reduzido à condição de vítima.

Teria a escrita desse livro operado para Virginie como um encontro com o pai Real? Formulo tal pergunta, pois acredito que ela estava identificada a um pai imaginário que a aprisionava em seu silêncio, na vergonha que esse lhe causara. Assim como o espanto produzido pelo encontro com Samuel Castro levou-a a abandonar o "nós" consistente condensado no enunciado "as crianças de 68", a arrancar-se da História como determinante, o espanto produzido pelo insuportável da fala do pai arrancou-a do aprisionamento. Se o encontro com o pai Real liberou, autorizou, também permitiu a Virginie interrogar como saber o que era da ordem de uma verdade. Para ter esse saber, dirá Lacan, é preciso "empenhar a própria pele" (1972/73, p. 103). Se reconhecermos a pele de Virginie na sua identificação ao "nós", então sim, podemos afirmar que ela empenhou sua própria pele em sua pesquisa!

O silêncio do pai pode agora restabelecer-se, sob outros termos, radicalmente diferentes, como modo singular de dar conta de um gozo, como uma escolha e não mais como um assujeitamento. Eu dizia no capítulo 1 que o encontro com o pai Real permite separar-se do gozo do Outro, separar-se para servir-se do pai, um pai que não oferece garantias, mas dá testemunho de uma relação possível com o gozo. O pai de Virginie perdeu para 
ela a consistência que o lugar de vítima de História lhe conferia, mas abriu-lhe brechas para a invenção, a escolha. Seu silêncio passou a ser lido por ela como um modo de tampar o buraco - a loucura - que é eficaz em fazer crer que não há buraco, e, nessa medida, confere um semblante no lugar do impossível. Esse arranjo, portanto, é singular, não extensível, não decorre de uma época, não se repete de pai para pai; não é compatível com um nós: não há, no Outro, garantias em que se agarrar (nem no "nós"). Vale marcar que ao irromper brevemente como falante e voltar a recolher-se no silêncio, a história de seu pai não se modificou; o que mudou foi o saber que Virginie pôde produzir sobre o pai, sobre seu silêncio, foi o efeito produzido por esse saber: ela concluiu sua pesquisa, pôs um ponto final, algo silenciou nela.

É exatamente neste ponto que a discussão sobre a historização pode ser retomada. Vejam que, ao pesquisar sobre os fatos historicamente determinados, não se trata de esgotar um tema; o silêncio do pai não só é historicizado por ela, mas também localizado em sua condição de tratamento possível do real.

Quando observo que o pai de Virginie produziu um saber sobre o impossível, produziu uma saída que é da ordem de uma invenção - foi o melhor médico para si mesmo, como constatou sua filha - faz sentido retomar a diferença entre impotência e impossível como efeitos do encontro com a inconsistência do Outro. Esta, se tomada em sua vertente de impossível, pode representar o fim do recurso ao Outro para solucionar ou regular sua relação com o gozo. Virginie pode então deslizar da impotência diante do silêncio do pai para a constatação do seu (do pai) modo singular de regular sua relação com o gozo. Esse seria o encontro com o pai Real, capaz de autorizá-la a assumir a sua (dela) singular relação com o gozo.

O tema do silêncio e dos nomes do pai fazem lembrar o famoso seminário interrompido por Lacan na primeira aula, Os nomes do pai. Porge (1998) hipotetiza que Lacan o manteve suspenso apostando no valor significante da suspensão. A interrupção é reconhecida como uma reação a medidas discriminatórias da IPA (Sociedade Internacional de Psicanálise) em relação à SFP (Sociedade Francesa de Psicanálise, da qual Lacan era um dos fundadores): "Porque se tinha querido fazê-lo calar, como se ele tivesse pronunciado uma blasfêmia ao falar dos nomes do pai, ele se calará, e fará deste silêncio uma palavra" (PORGE, 1998, p. 86). No entanto, parece não esgotar seu valor 
nesse ato de repúdio: Lacan manteve o seminário suspenso, não retomando-o ao longo de seu ensino.

O que chamou particularmente a minha atenção nesse fato histórico foi uma coincidência, destacada por Porge entre a interrupção do seminário e a autorização concedida no dia da primeira e única aula desse seminário - recebida por Lacan para dar seu nome à filha Judith ${ }^{146}$. No mesmo momento em que suspende sua fala sobre o pai, Lacan tornou-se legalmente pai; foi, ele mesmo, reconhecido como pai. Então instituiu o silêncio. De que fala o seu silêncio, embora possamos fazer conjecturas, cada um é que sabe. Virginie detém agora um saber sobre o silêncio. Conclui sua pesquisa com a seguinte frase: "então silêncio".

\footnotetext{
${ }^{146}$ Quando Judith nasceu, sua mãe Sylvia ainda estava casada com G. Bataille. Dada a proteção que este casamento lhe conferia por tratar-se de um não-judeu. Com a morte deste, Lacan dá início ao processo de legitimação de sua paternidade (PORGE, 1998).
} 


\section{Capítulo 5 - Considerações finais: a parentalidade para todos, não sem a família de cada um ${ }^{147}$}

O modo como eu havia estruturado inicialmente esta pesquisa, situando de um lado a família como resíduo e a parentalidade de outro, me levava a assumir uma posição de oposição ou resistência ao novo termo, como se a psicanálise, ela mesma constituindose em um discurso integrante desta época ${ }^{148}$, habilitasse uma posição sobre a procedência ou não do neologismo parentalidade. Naquele momento, eu me preocupava em enfrentar os discursos que apontavam para a inevitabilidade da intervenção do especialista e, ao mesmo tempo, em me situar em relação ao temor de que o neologismo parentalidade viesse a substituir a família e de que a diferença (sexual) fosse eliminada da transmissão familiar.

O destaque conferido por Tort (2006) às confusões armadas pelos especialistas sobre o que são práticas sociais e o que diz respeito ao funcionamento psíquico, chamando a atenção para o fato de que são as práticas sociais que definem um certo número de realidades e não aqueles, foi fundamental para que eu abandonasse aquela perspectiva inicial. Também foi determinante a proposição do mesmo autor de conceber a inventividade terminológica como um modo de dar conta das mudanças nas práticas sociais. Analisar separadamente cada uma das vertentes pelas quais o termo parentalidade comparece na atualidade ${ }^{149}$ (sempre levando em conta que cada uma delas e os discursos que lhes são subjacentes se influenciam mutuamente, tornando praticamente impossível encontrar cada umas dessas dimensões em estado "puro") e ler a consistência que o termo parentalidade vem ganhando na atualidade e as práticas que lhe são subjacentes como o "sintomático desta época" pareceram-me posicionamentos condizentes com os pontos destacados pelo autor.

\footnotetext{
147 Afirmação proposta em ressonância à Convocatória do $5^{\circ}$. Encontro Americano de Psicanálise de Orientação Lacaniana (ENAPOL) - XVII Encontro Nacional do Campo Freudiano: “A saúde para todos, não sem a loucura de cada um - perspectivas da psicanálise"

148 O psicanalista, ao constituir-se em um integrante desta época, também contribui para a sua produção (DUNKER, 2008).

${ }^{149}$ Como um modo de nomear o parent ou aquele que ocupa o lugar, como um meio de dar conta das transformações no campo da família e como um discurso de ordem pública.
} 
Ao tratar separadamente as diferentes dimensões pelas quais o termo parentalidade se inscreve na atualidade, foi possível destacar que minha crítica recaía sobre os discursos normativos e ortopédicos sobre a parentalidade e observar que, no campo jurídico, o novo termo pode ser bem-vindo, já que responde à demanda por reconhecimento e legitimidade das novas formas de família. As ficções jurídicas pretendem organizar e legitimar práticas já existentes e não implicam na exclusão da diferença do campo da família. No entanto, no decorrer do capítulo 2, mostrei como se atualiza uma grande confusão entre teorias psicológicas, práticas sociais e convicções políticas e pessoais no que se refere às novas formas de família e à procriação medicamente assistida, a ponto de as demandas procedentes do ponto de vista jurídico acabarem sendo apropriadas por outros discursos, às vezes de forma imprecisa e ideológica.

A especificidade da psicanálise em relação aos outros discursos reside no fato de que, embora o que se demande do psicanalista seja desembaraçar-se do real e do sintoma, este está advertido de que não há como eliminar o real. Sua intervenção consiste justamente em apontar para o real (lembremos que o discurso da ciência pretende superar o que é da ordem real, esquecendo-se de que é também um semblante). Nesse ponto, ou seja, diante da demanda pela eliminação do real, é preciso que a psicanálise continue a falhar (LACAN, 1974).

É importante assinalar que não é do psicanalista que depende o advento do real, aquele só faz apontar para este. Evidentemente, para o psicanalista, não se trata de responder à demanda! A ética do bem-dizer não se confunde com dizer onde está o bem, não cabe à psicanálise armar consistência sobre como as coisas devem ser (ou, mais especificamente, sobre quais devem ser as competências parentais). Contudo, o que se nota é que, em relação ao tema da família, muitos se sentem impelidos a dizer onde está o bem, às vezes até mesmo o psicanalista. Mas então ele corre o risco de posicionar-se como um especialista e de engrossar o discurso sobre a inevitabilidade da intervenção.

No decorrer das leituras realizadas ao longo desta pesquisa, havia uma formulação de Laurent (2010b) que me intrigava. O autor assinalava a função do analista de proteger a criança do delírio familiarista de seus pais, diferenciando-se em relação aos psicoterapeutas. Entendo agora a crítica em relação às psicoterapias, pois estas abordam as funções parentais por meio de um viés funcionalista, atribuindo uma consistência 
sobre como deve ser o "papel do pai" e o "papel da mãe"; o que encorparia a fantasia dos pais de que existe uma boa versão de família, e que, para tal, bastaria seguir as orientações e prescrições do especialista. Najles (2008) destaca um aspecto aparentemente simples, mas fundamental: é como sujeitos que se escutam pai e mãe no tratamento de uma criança, isto é, não há como isolar, ao escutar o sujeito, o pai, a mãe ou a parentalidade. Não é possível assumir uma faceta "só pai" ou "só mãe" ao se criar uma criança, o que é da ordem do sexual, que se pretende expulsar nos discursos normativos e ortopédicos sobre a parentalidade, retorna quando é do sujeito que se trata.

A propósito da chamada para o V Enapol - "A saúde para todos, não sem a loucura de cada um” - Marcus André Vieira ${ }^{150}$, diretor do evento, fez o seguinte comentário:

O ‘não sem’ de nosso título convida a outro caminho. Esta expressão afasta a simples oposição entre seus termos. A loucura não será definida, como de hábito, como o contrário da saúde mental ou da razão, mas acrescenta-se a elas como condição imprescindível.

Vieira, ao propor uma articulação entre saúde mental e loucura, convidou a se fazer uma báscula entre esses termos, ao invés de polarizá-los e convertê-los em excludentes. Com isso, inspirou um tratamento possível ao binômio sobre o qual me detive ao longo deste trabalho: parentalidade e família. Antes que opor-se ao que o discurso social produz como modo de sutura da falta na atualidade ou mesmo fazer-lhe resistência, pode-se formular que a parentalidade ${ }^{151}$ "não é sem” a família em sua condição de resíduo, ou, outro modo de dizê-lo, a família se reintroduz na parentalidade "como condição imprescindível”. Penso que esse é um modo possível de tratar tais termos e, ao assumilo como possível, entendo ser o que permite que, por um tempo, as articulações entre família e parentalidade parem de não se escrever.

A família faz furo, descompleta a parentalidade. Ao bascular entre o universal e o homogêneo que os discursos sobre a parentalidade veiculam e a singularidade inerente à noção de família como resíduo, a psicanálise faz comparecer a impossibilidade de recobrimento da falta (condensada no aforismo lacaniano "não há relação sexual”). De

150 Texto de apresentação do V ENAPOL. Disponível no endereço eletrônico: http://www.ebp.org.br/enapol/09/pt/template.asp?apresenta/asaudeparatodos.htm

${ }^{151}$ O termo "parentalidade" aqui é tomado como o sintomático de uma época, portanto, em termos dos discursos que o animam, das práticas que autoriza e das famílias que regulariza. 
modo que ao PARA TODOS dos discursos subjacentes à noção de parentalidade, à psicanálise cabe responder reenviando cada família, e aqui insisto no significante "família", à sua singularidade. Ao apontar para a unicidade do gozo e para a responsabilidade do sujeito por aquilo que faz de seus determinantes, a função residual da família fura a consistência do genérico "parentalidade". Ancorada nas funções materna e paterna e nos modos como pai e mãe se conformam em semblantes, a família como resíduo estaria do lado da estrutura. Esta, apesar de necessária, depende do que é da ordem da contingência, ou seja, é descompletada pelos traços, posições e valores que prevalecem em determinada época e pela posição singular dos sujeitos implicados em cada uma dessas funções.

Os comentadores de Lacan que se dedicam ao tema da família na atualidade e que foram estudados e citados ao longo desta pesquisa apresentam, cada um à sua maneira, suas leituras sobre o mal-estar parental, destacando sempre o real como o que não pretende deixar de não se escrever. Essa posição é evidenciada na letra de Eric Laurent (2010a), ao afirmar que nenhuma ficção pode dar conta do real que é a chegada de uma criança numa família, na letra de Marie-Hélène Brousse (2010), ao observar que o sintoma tem muitos dias adiante, e na letra de Gustavo Stiglitz (2009), ao assinalar que nenhuma ficção reduz o impossível de escrever a relação sexual e que cabe à psicanálise cuidar da tentação de querer cobrir o real com as ficções.

Em A Terceira, texto de 1974 Lacan se pergunta sobre as quinquilharias, em clara referência ao discurso capitalista: tomarão elas a dianteira? Responde enfático que isso é pouco provável. O real, ao que parece, não tem seus dias contados! A família, como vimos ao longo desta pesquisa, tampouco tem seus dias contados! Se o termo parentalidade condensa o modo prevalente de sutura da falta nesta época, ao psicanalista, mais uma vez, cabe apontar para o real, e, neste caso específico, para a família em sua função de resíduo e para o sujeito em sua unicidade.

Entre os leitores de Lacan que se dedicam à família e à parentalidade, pude observar também que, vez por outra, não é tão raro, o tema do declínio da função paterna reaparece; vez por outra também, mas com mais freqüência, surgem leituras mais alarmistas a respeito das mudanças no campo da família e do futuro das crianças. Desta 
forma, há psicanalistas ${ }^{152}$ que, ao se dedicarem a essa temática, parecem embaraçar-se, denotando o temor de que a parentalidade possa vir a se substituir à família em sua condição de resíduo, implicando em um risco para elas, ou seja, para "os filhos da parentalidade". Reproduzi no final do capítulo 3 alguns trechos de autores que denotavam tal preocupação, e vale assinalar que esses autores tratam o neologismo "parentalidade" de forma genérica, sem atentar para os diferentes discursos que se encontram em sua base, o que pode levar a confusões e imprecisões em suas análises.

Ao longo desta pesquisa, penso ter reunido elementos para questionar a preocupação revelada por esses autores e mesmo a validade de enunciados como "os filhos da parentalidade". Um dos "achados" em direção ao qual o espanto me precipitou é que uma época não conforma a um "nós" os sujeitos que dela fazem parte. A família, reduzida à sua condição mínima, ou seja, a família como resíduo, aliada à formulação de que a parentalidade pode ser lida como o sintomático desta época consistiram em elementos fundamentais para a assunção dessa posição.

A consistência e as implicações que Virginie Linhart, em $O$ dia em que meu pai se calou, pretendia subtrair do enunciado "as crianças de 68", precipitaram-me ao tempo de concluir. Assim como a autora, eu iniciara minha investigação munida de algumas hipóteses, mas não sabia exatamente aonde elas me permitiriam aportar. Além disso, me pretendia advertida em relação a alguns riscos para os quais o tema escolhido poderia me levar. No início do capítulo 4, assinalei que a pesquisa de Virginie comparecia nesta tese pelo espanto que causara em mim a consistência implícita em seu enunciado "as crianças de 68", infletindo o rumo de minha pesquisa, e que examiná-la me permitia: posicionar-me diante de enunciados como "os filhos da parentalidade", pontuando que este "nós" não existe, e ilustrar a função do pai como resíduo (ou como opera o pai Real). Mas só-depois um terceiro aspecto, não previsto anteriormente, foi se delineando: o sinthoma como uma formulação que sustenta haver um (não sem os outros) e que definitivamente esvazia a consistência do "nós" sonhado por Virginie; noção que Harari (2002) define de forma excepcional: "Não se trata, é claro de solidão subjetivada, vivencial, mas do Um como formação psíquica em Hiância com o Outro" (p. 215, grifo meu).

${ }^{152}$ Como NEGRI, 2010, RUSSO, 2010 e TORRES, 2010, autores citados no final do capítulo 3. 
Pretendendo furar o "nós" subjacente ao enunciado "os filhos da parentalidade" me vi impelida a buscar uma formulação mais precisa acerca do um em sua relação com o Outro (questão que foi trabalhada por meio da noção de pai Real). Tocar na noção de sinthoma, portanto, foi se tornando quase inevitável, a partir do modo como os elementos foram sendo costurados no momento de concluir esta pesquisa.

A noção de sinthoma ${ }^{153}$ foi formulada no último ensino do Lacan, em um momento no qual o psicanalista não mais procedia a um retorno a Freud, mas habilitou a invenção, conceito absolutamente articulado ao Um e ao singular. Essa noção encontra fundamento na especificidade da relação do Um com o Outro, e é a partir desse ponto específico que a menciono aqui, embora seja importante frisar tratar-se de uma noção complexa, que se articula de modo específico com a noção de sintoma e que tem implicações importantes para a direção da cura em uma análise. Penso que se trata de uma formulação crucial de um Lacan que aspirava a estar à altura de sua época.

O modo como a análise das articulações possíveis entre os termos família, parentalidade e época foi sendo tecida ao longo desta pesquisa me permite retornar aos interrogantes formulados inicialmente e assumir uma posição: a parentalidade, um modo de sutura da falta sintomático desta época, não implica um risco para que haja um amanhã no qual a transmissão familiar, com suas falhas e imperfeições, continue vigorando. Ao exceder o "nós" no modo de gozo singular do qual cada pai e cada mãe dão testemunho na transmissão, a família tende a continuar abrindo furos na consistência e na assepsia previstas nos discursos normativos e ortopédicos sobre a parentalidade.

${ }^{153}$ C.f. LACAN, J. (1975/76) O Seminário, Livro 23: O Sinthoma. Rio de Janeiro: Jorge Zahar, 2007; e HARARI, R. (2002) Como se chama James Joyce? A partir do seminário Le sinthome de J. Lacan. Salvador: Ágalma/Rio de Janeiro: Companhia de Freud. 


\section{Referências bibliográficas}

ARENDT, H. A crise na educação. In: Entre o passado e o futuro. São Paulo: Editora Perspectiva, 2003.

AUBOURG, F. La Maison Verte: un dispositif à la portée de l'enfant. Figures de la psychanalyse, $2009 / 2$ no. 18 , p. 227-240.

ASKOFARÉ, S. Da subjetividade contemporânea. In: A peste. São Paulo, v.1, n. 1, p. 165-175, jan/jun 2009.

BASSOLS, M. El sujeto moderno en la sociedad de la tecnociencia. In : Colofon Boletín de la Federación Internacional de Bibliotecas del Campo Freudiano. Política de lãs cosas, política de la ciudad, n. 27, junio de 2007, p. 9- 15.

BENOIT, P. Ce qu' est la Maison Verte. Document n 15, 1988, p. 149-158. In: Une psychanalyste dans la cite - l'aventure de la Maison Verte. Paris: Éditions Gallimard, 2009.

BERNARDINO, L.M.B. A abordagem psicanalítica do desenvolvimento infantil e suas vicissitudes. In: $O$ que a psicanálise pode ensinar sobre a criança, sujeito em constituição? Bernardino, L.M.F. (org.) São Paulo: Escuta, 2006.

BEZERRA Jr., B. O ocaso da interioridade e suas repercussões sobre a clínica. In: PLASTINO, C. A. (org.) Trangressões. Rio de Janeiro : Contracapa, 2002.

BOUREGBA, A. Du paternel au parental: quels effets pour l'enfant? In: COUM, D. (org). La famille change-t-elle? Paris: Editions Érès, 2006.

BRITO, M. T. Criança: sujeito de direitos nas varas de família? In: ALTOÉ, S. (org.) Sujeito do Direito, Sujeito do Desejo - Direito e Psicanálise. Rio de Janeiro: Revinter, 103-129, 2004.

BRODSKY, G. Conferência: as utopias contemporâneas. In: Carta de São Paulo Boletim da Escola Brasileira de Psicanálise, São Paulo. Edição Especial, ano XVI, março de 2009. 
BROUSSE, M.-H. As interpretações lacanianas do Complexo de Édipo freudiano. Conferências proferidas em 30 de junho e 1 de julho de 1997. In: Arquivos da Biblioteca, n. 1, Escola Brasileira de Psicanálise, RJ, novembro de 1997, p. 53-87.

Un neologismo de la actualidad: la parentalidad. In: TORRES, M., FARAONI, J. e SCHNITZER, G. (orgs.). Uniones Del mismo sexo - diferencia, invención y sexuación. Buenos Aires: Grama Ediciones, p. 139-148, 2010.

BRUNO, P. Du père rèel. In: La Passe- papiers psychanalytiques II. Toulouse: Presses Universitaires du Mirail, p.161-184, 2003.

CABRAL, A. C. En la cura analítica, proteger a la historia de la Historia. In:

FIORINI, L. G. (org) Tiempo, historia y estructura - su impacto en el psicoanálisis contemporâneo. Buenos Aires: Lugar Editorial, p. 121-137, 2006.

CALLIGARIS, C. Três conselhos para a educação das crianças. In: Educa-se uma criança? Calligaris, C. et alli (org.) Associação Psicanalítica de Porto Alegre. Porto Alegre: Editora Artes e Ofícios, 1994.

CECCARELLI, P. R. Novas configurações familiares: mitos e verdades. In: Jornal de Psicanálise. Instituto de Psicanálise - SBPSP. Volume 40 - junho de 2007, n. 72.

CARONE, M. Tradução e posfacio. In: Carta ao pai (KAFKA, F.) São Paulo: Companhia das letras, 1997.

CHEMAMA, R. Dicionário de Psicanálise. Porto Alegre: Artes Médicas Sul, 1995.

Um sujeito para o objeto? In: GOLDENBARG, R. (org.) Goza! Capitalismo, globalização e psicanálise. Salvador: Ágalma, p. 23-39, 1997.

COSTA, J. F. Ordem médica e norma familiar. Rio de Janeiro: Edições Graal, 2004.

COTTET, S. El padre pulverizado. In: Uniones Del mismo sexo - diferencia, invención y sexuación. Buenos Aires: Grama Ediciones, p. 159-169, 2010.

DAUMAS, A. e STIGLITZ, G. Políticas para la infancia - conversación com Guillermo Belaga, Walter Capelli y Gustavo Schujman. In: Psicoanálisis con niños y adolescentes 2. Políticas, prácticas y saberes sobre el niño. Buenos Aires: Editorial Grama, p. 21-41, 2009. 
DELAISE de PARSEVAL, G. D. Le sexuel et le parental. In: COUM, D. (org). La famille change-t-elle? Paris: Editions Érès, 2006.

DERRIDA, J. e ROUDINESCO, E. De que amanhã... Diálogo. Rio de Janeiro: Jorge Zahar, 2004.

DIDIER-WEILL, A. Os três tempos da lei - o mandamento siderante, a injunção do supereu e a invocação musical. Rio de Janeiro: Jorge Zahar Editores, 1997.

DOLTO, F. Prefácio. In: MANNONI, M. A primeira entrevista em psicanálise. Rio de janeiro: Editora Campus, p. 9-30, 1981.

Quando os pais se separam. São Paulo: Jorge Zahar Editor, 1989.

DOLTO, F.; MALANDRIN, M.-H. (ed.); SCHAUDER, C. (ed.). Une psychanalyste dans la cite - l'aventure de la Maison Verte. Paris: Éditions Gallimard, 2009.

DUNKER, C. I. L. A psicanálise em seu tempo. In: Os tempos do sujeito do inconsciente. A psicanálise em seu tempo e o tempo na psicanálise. V Encontro Internacional da IF - EPFCL. São Paulo, Brasil, 5 e 6 de julho de 2008. Disponível no endereço eletrônico: http://www.campopsicanalitico.com.br/biblioteca/anais.pdf

ELIACHEFF, C. La famille dans tous ses états. Paris: Éditions Albin Michel, 2004.

FABLET, D. L'émergence de la notion de parentalité en milieu(x) professionnel(s). In: n 5 I printemps 2008 - Parentalité et pratiques socio-éducatives. Disponível no endereço eletrônico : http://sejed.revues.org/index3532.html

FASSIN, E. La voix de l'expertise et les silences de la silence dans le débat démocratique. In: BORILLO, D. e FASSIN, E. (orgs.) Au-delà du PaCS - l'expertise famliale à l'épreuve de l'homossexualité. Paris: Presses Universitaires de France, 2001.

FIORINI, L. G. e VINOCOUR-FISCHBEIN, S. Entrevista a Ernesto Laclau. In: FIORINI, L. G. (org) Tiempo, historia y estructura - su impacto en el psicoanálisis contemporâneo. Buenos Aires: Lugar Editorial. p. 111-119, 2006.

FREUD, S. (1908) Novela familiar do neurótico. In: Obras Completas. Madrid: Editorial Biblioteca Nueva, 1981, volume I, p. 1361-1363 
(1908b) La moral "cultural" y nerviosidad moderna. In: Obras Completas.

Madrid: Editorial Biblioteca Nueva, 1981, volume II, p. 1249-1261.

- (1910) El porvenir de la terapia psicoanalitica In: Obras Completas.

Madrid: Editorial Biblioteca Nueva, 1981, volume II, p 1564- 1570.

(1912-13) Totem y Tabu. In: Obras Completas. Madrid: Editorial Biblioteca Nueva, 1981, p. 1746-1850.

(1914) Recuerdo, repeticion y elaboracion. In: Obras Completas. Madrid:

Editorial Biblioteca Nueva, 1981, volume II, p. 1683-1688.

. (1919) Lo Siniestro. In: Obras Completas. Madrid: Editorial Biblioteca Nueva, 1981, volume III, p. 2483- 2506.

(1920-21) Psicologia de las masas y analisis del yo. In: Obras Completas.

Madrid Editorial Biblioteca Nueva, 1981, volume III, p. 2563-2610.

(1927) El porvenir de una ilusion. In: Obras Completas. Madrid: Editorial

Biblioteca Nueva, 1981, volume III, p. 2961-2992.

. (1929) El malestar en la civilización. In: Obras Completas. Madrid:

Editorial Biblioteca Nueva, 1981, volume III, p. 3017-3067.

(1932) Nuevas lecciones introductorias ao psicoanalisis - Leccion XXXIV -

Aclaraciones, aplicaciones y observaciones. In: Obras Completas. Madrid: Editorial Biblioteca Nueva, 1981, volume III, p. 3178- 3190

FORGET, J.-M. Quelles seraient les spécificités d'un matriarcat ordinaire actuel ? In: Le Bulletin. N. 2. Le dossier: résurgence du matriarcat? Association Lacanienne Internationale. Paris: Editions de 1'A.L. I., 2007.

FRANÇOIS, Y. Françoise Dolto - de la ética a la practica del psicoanalisis de niños. Buenos Aires: Nueva Visión, 1992.

GAVARINI, L. A. Du contrôle social à la prédiction: évolution du regard sur l'enfance, In: (orgs) NEYRAND, G., DUGNAT,M., REVEST, G. e TROUVÉ, J.-N. Familles et petite enfance. France: Érès, p. 93-108, 2006. 
. (2008) Novas normas e formas de laço familiar: a sexualidade na sombra. In:

Estilos da clínica. São Paulo, v.13, n.25, dez. 2008. Disponível em: http://www.revistasusp.sibi.usp.br/scielo.php?script=sci_arttext\&pid=S1415$71282008000200016 \& \operatorname{lng}=$ pt\&nrm=iso. Acesso em 17 jan. 2011.

Criança, sujeito de direitos e objeto de saberes. In: Formação de profissionais e a criança-sujeito, 7, 2009, São Paulo. Endereço eletrônico: http://www.proceedings.scielo.br/scielo.php?script=sci_arttext\&pid=MSC00000000320 08000100007\&lng=en\&nrm=abn.

GIAMPINO, S. Propôs sur la parentalité d'aujourd'hui. In: COUM, D. (org). La famille change-t-elle? Paris: Editions Érès, p. 33-43, 2006.

HAMAD, N. A criança adotiva e suas famílias. Rio de Janeiro: Companhia de Freud, 2002.

Adoção e parentalidade: questões atuais. Porto Alegre: CMC Editora, 2010.

HARARI, R. Como se chama James Joyce? A partir do seminário Le sinthome de J. Lacan. Salvador: Ágalma/Rio de Janeiro: Companhia de Freud, 2002.

HOUZEL, D. As implicações da parentalidade. In: Solis-Ponton, L.(org). Ser pai, ser mãe. Parentalidade: um desafio para o terceiro milênio. Uma homenagem internacional a Serge Lebovici. São Paulo: Casa do Psicólogo, 2004.

HURSTEL, F. Malaise dans la filiation paternelle: que devient la fonction du tiers? In: Cliniques méditerranéennes. N. 64, 2001/2002, p. 5-19. disponível no endereço eletrônico: http://www.cairn.info/revue-cliniques-mediterraneennes-2001-2-p-5.htm

JULIEN, P. Abandonarás teu pai e tua mãe. Rio de Janeiro: Companhia de Freud, 2000 .

KAFKA, F. Carta ao pai. Tradução e posfacio: Modesto Carone. São Paulo: Companhia das letras, 1997.

KAUFMANN, P. Dicionário Enciclopédico de Psicanálise: o legado de Freud e Lacan. Tradução de Vera Ribeiro, Maria Luiza X. de A. Borges; consultoria, Marco Antônio Coutinho Jorge. Rio de Janeiro: Jorge Zahar editor, 1996. 
KEHL, M. R. Sobre ética e psicanálise. São Paulo: Editora Companhia das Letras, 2002.

Em defesa da família tentacular. 2003. Disponível no endereço eletrônico: http://www.mariaritakehl.psc.br/PDF/emdefesadafamiliatentacular.pdf

KOLTAI, C. Totem e tabu - um mito freudiano. Rio de Janeiro: Civilização brasileira, 2010.

LACAN. J. (1938) Os complexos familiares na formação do indivíduo. Rio de Janeiro: Jorge Zahar, 2002.

. (1945) O tempo lógico e a asserção de certeza antecipada. In: Escritos. Rio de Janeiro: Jorge Zahar, 1998, p. 197-213.

(1952) Mito individual do neurótico. Lisboa: Assírio \& Alvim, 1980.

. (1953a) O simbólico, o imaginário e o real. In: Os nomes-do-pai. Rio de Janeiro, Jorge Zahar, 2005, p. 11- 53.

. (1953b) Discurso de Roma. Outros escritos. Rio de Janeiro: Jorge Zahar, 2003, p.139-172.

(1953c) Função e campo da fala e da linguagem na psicanálise. Escritos. Rio de Janeiro: Jorge Zahar, 1998, p. 238-324.

. (1953d) A significação do falo. In: Escritos. Rio de Janeiro: Jorge Zahar, 1998, p. $692-703$

. (1953/54) O seminário, livro 1: Os escritos técnicos de Freud. Rio de Janeiro: Jorge Zahar Editor.

$402-437$

. (1955) A coisa freudiana. In: Escritos. Rio de Janeiro: Jorge Zahar. 1998, p.

. (1955/56) De uma questão preliminar a todo tratamento possível da psicose.

In: Escritos. Rio de Janeiro: Jorge Zahar. 1998, p. 537-590. 
- (1957/58) O seminário, livro 5: as formações do inconsciente. Rio de Janeiro: Jorge Zahar, 1999.

. (1958) A direção do tratamento e os princípios de seu poder. In: Escritos. Rio de Janeiro: Jorge Zahar, 1998, p. 591-652.

(1959/60) O Seminário. Livro 7: A ética da psicanálise. Rio de Janeiro: Jorge Zahar, 1997.

. (1967) Alocução sobre as psicoses da criança. In: Outros Escritos. Rio de Janeiro: Jorge Zahar, 2003, p. 359-368.

. (1969) Nota sobre e a criança. In: Outros Escritos. Rio de Janeiro: Jorge Zahar, 2003, p. 369-370.

(1969/1970) O seminário, Livro 17: O avesso da Psicanálise. Rio de Janeiro : Jorge Zahar, 1992.

. (1971) O seminário, Livro 18: De um discurso que não fosse semblante. Rio de Janeiro: Jorge Zahar, 2009.

(1972/73) O Seminário, Livro 20: Mais, ainda. Rio de Janeiro, Jorge Zahar, 2008

(1974) A Terceira. Comunicação feita ao Congresso da EFP em Roma. In: UM Lacan inéditos. Escola Freudiana de São Paulo. Departamento de publicações internas, 1981, p. 1-32.

. (1974/75) R.S.I. Seminário inédito.

Zahar, 2007.

(1975/76) O Seminário, Livro 23: O Sinthoma. Rio de Janeiro: Jorge (1976) Prefácio à edição inglesa do Seminário 11. Outros escritos. Rio de Janeiro: Jorge Zahar, 2003, p. 567-569. 
(2002) Les clefs de la psychanalyse. Entrevista publicada em Les archives de L'Express du 31/05/1957 - mis à jour le 17/05/2002. Disponível no endereço eletrônico: http://www.lexpress.fr/actualite/sciences/sante/les-clefs-de-la-sychanalyse_499017.html

LAIA, S. Declinações do pai em Lacan. In: Latusa 11 - Para que serve um pai? Usos e Versões - Escola Brasileira de Psicanálise - Rio de Janeiro, 2006, p. 39-56.

LAJONQUIÈRE, L. Figuras do infantil. A psicanálise na vida cotidiana com as crianças. Petrópolis, RJ: Vozes, 2010.

LAPLANCHE e PONTALIS Vocabulário de psicanálise. São Paulo: Martins Fontes, 1998.

LAURENT, E. A sociedade do sintoma. A psicanálise, hoje. Rio de Janeiro: Contra Capa Livraria. Opção Lacaniana n. 6, 2007.

El niño como reverso de las familias. In: TORRES, M., FARAONI, J. e SCHNITZER, G. (orgs.). Uniones Del mismo sexo - diferencia, invención y sexuación. Buenos Aires: Grama Ediciones, 2010a, p. 149- 158.

. El niño como real del delírio familiar. In: KUPERWAJS, I. (Org.) Psicoanálisis con niños 3 - tramar lo singular. Buenos Aires: Grama Ediciones, 2010b, p. 19-25.

LEBRUN, J.- P. Um mundo sem limite: ensaio para uma clínica psicanalítica do social. Rio de Janeiro: Companhia de Freud, 2004.

A perversão comum - viver juntos sem outro. Rio de Janeiro: Campo matêmico, 2008.

. O mal-estar na subjetivação. Porto Alegre: CMC Editora, 2010.

LEDOUX, M. Introdução à obra de Françoise Dolto. Coleção Transmissão da psicanálise. São Paulo: Editora Jorge Zahar, 1991.

LÉVI-STRAUSS, C. As estruturas elementares de parentesco. Tradução de Mariano Ferreira. 4. Petrópolis: Vozes, 2008.

LINHART, V. Le jour où mon père s'est tu. Paris : Seuil, 2008. 
LISPECTOR, C. Laços de família. Rio de Janeiro: Rocco, 1998.

MALANDRIN, M.-H. Éducation/psychanalyse, l'impossible nouage ? In : Une psychanalyste dans la cite - l'aventure de la Maison Verte. Paris : Éditions Gallimard, 2009, p. 11-105.

MAÏLAT, M. Quels regards sur les parents? In: COUM, D. (org). La famille change-telle? Paris: Editions Érès, 2006, p. 45-52.

MANDEUlbaUn, B. Psicanálise da família. Coleção clínica psicanalítica: dirigida por Flávio Carvalho Ferraz. São Paulo: Casa do Psicólogo, 2008.

MARCELLI, D. L'enfant chef de la famille. Reunión-débat organizée par "Gandir ensemble", 2004. Disponível no endereço eletrônico: http://santesavoie.org/docs/enfant_chef_de_la_famille.pdf

MARTIM, C. La famille a-t-elle changé? In: COUM, D. (org). La famille change-telle? Paris: Editions Érès, 2006a, p. 7-18.

La parentalité: une question politique. In: COUM, D. (org). La famille change-t-elle? Paris: Editions Érès, 2006b, p. 53-63.

MILLER, J.-A. e MILNER, J.-C. Você quer mesmo ser avaliado? : entrevistas sobre uma máquina de impostura. São Paulo: Manole, 2006.

MILLER, J. A. Leitura crítica dos "Complexos familiares" de Jacques Lacan. In: Opção lacaniana online. 1984. Tradução de Vera Avellar Ribeiro. Disponível no endereço eletrônico:

http://www.opcaolacaniana.com.br/antigos/n2/pdf/artigos/JAMLeitura.pdf

Assuntos de famílias no inconsciente. In: Asephallus - revista eletrônica do núcleo Sephora. Vol. II, n. 4, maio a outubro de 2007.

NAJLES, A. R., Problemas de aprendizaje y psicoanálisis. Buenos Aires: Gramma Ediciones, 2008. 
NAPARSTEK, F. A. Do pai universal ao pai singular. In: Latusa 11 - Para que serve um pai? Usos e Versões - Escola Brasileira de Psicanálise - Rio de Janeiro, 2006, p. 163-175.

NEGRI, I. De la orientación paterna a la orientación «parental ». In: TORRES, M., FARAONI, J. e SCHNITZER, G. (orgs.). Uniones Del mismo sexo - diferencia, invención y sexuación. Buenos Aires: Grama Ediciones, 2010, p. 187-194.

NEYRAND, G. La place de la petite enfance das la reconfiguratin du champ des savoirs sur la famille. In : NEYRAND, G. e DUGNAT, M. (orgs) Familles et petite enfance mutations des savoirs et des pratiques. Editions Érés, 2006, p. 109-120.

NOMINÉ, B. A família e o sintoma: questões a Bernard Nomine. In: Revista Correio n. 17. Escola Brasileira de Psicanálise, 1997, p. 82-86.

PACHECO, R. A peste do capitalismo e a praga da psicanálise. In: A peste. São Paulo, v.1, n. 1, p. 143-163, jan/jun 2009.

PASSOS, M. C. Homoparentalidade: uma entre outras formas de ser família. In: Psicologia Clínica. Rio de Janeiro, v. 17, n. 2, 2005. Disponível no endereço eletrônico: http://www.scielo.br/scielo.php?script=sci_arttext\&pid=S0103-

$56652005000200003 \& \operatorname{lng}=$ en\&nrm=iso $>$.

PEUSNER, P. El sufrimiento de los niños. Buenos Aires: Letra Viva, 2009.

PIOLI, D. Le soutien à la parentalité : entre émancipation et contrôle. $\mathrm{n}^{\circ} 1 \mid$ printemps, 2006 : Varia Sociétés et jeunesses en difficulté - Revue pluridisciplinaire de recherche. Disponível no endereço eletrônico: http://sejed.revues.org/index106.html

PLANTET, J. La parentalité, un concept en vogue. Publication $n^{\circ} 722$ du 23 septembre 2004. Disponível no endereço eletrônico: http://www.liensocial.com/spip.php?article400\&id_groupe $=5$

PORGE, E. Os nomes do pai em Jacques Lacan. Rio de Janeiro: Companhia de Freud, 1998.

PUJÓ, M. Para una clínica de la cultura. Buenos Aires: Grama Ediciones, 2006. 
RICHARD, F. La parentalité, une notion à discuter. In: L'Esprit du Temps, Adolescence, 2006/1, Tome 55, p.43-53.

REY-FLAUD, H. Os fundamentos metapsicológicos de $O$ mal-estar na cultura. In: (orgs.) LE RIDER, J., PLON, M., RAULET, G. e REY-FLAUD, H. Em torno de $\boldsymbol{O}$ mal-estar na cultura, de Freud. São Paulo: Escuta, 2002, p. 5-68.

RITVO, J. O conceito de letra na obra de Lacan. In: A prática da letra. Escola Letra Freudiana, n. 26, Rio de Janeiro, 2000, p. 9-24.

ROSA, M. D. O lugar da criança e a família na contemporaneidade. In: A criança o infantil na clínica psicanalítica. Literal, 9, Escola de Psicanálise de Campinas, 2006, p. $115-128$.

ROUDINESCO, E. A família em desordem. Rio de Janeiro: Jorge Zahar Editor, 2003.

RUSSO, P. Qué hacer con la parentalidad? Uniones Del mismo sexo - diferencia, invención y sexuación. Buenos Aires: Grama Ediciones, 2010, p. 207-213.

SALMAN, S. Las Singularidades del Uno. In: KUPERWAJS, I. (Org.) Psicoanálisis con niños 3 - tramar lo singular. Buenos Aires: Grama Ediciones, 2010, p. 39-47

SANTIAGO, J. A clínica da pai-versão: um adeus ao pai morto. Latusa 11 - Para que serve um pai? Usos e Versões - Escola Brasileira de Psicanálise - Rio de Janeiro, 2006, p. 73-89.

SAURET, M. J. O infantil \& a estrutura. São Paulo: Escola Brasileira de Psicanálise, 1998.

SOLIS-PONTON, L. A construção da parentalidade. In: Solis-Ponton, L. (org). Ser pai, ser mãe. Parentalidade: um desafio para o terceiro milênio. Uma homenagem internacional a Serge Lebovici. São Paulo: Casa do Psicólogo, 2004.

SOLIMANO, M. L. Se eligen los amigos, no la família - pluralidad de las familias y singularidad del goce. In: Enlaces - psicoanálisis y cultura. Revista del Departamento de estudios psicoanalíticos sobre la família - Enlaces. Buenos Aires: Grama Ediciones. Ano 10, n. 13, 2008, p. 87-88.

SFAR, J. O Gato do rabino. V.1 : O Bar-Mitzvah. Rio de Janeiro: Jorge Zahar, 2006.

SILVA, J. M. O que pesquisar quer dizer - como fazer textos acadêmicos sem medo da ABNT e da Capes. Porto Alegre: Editora Sulina. 
SOUSA, E. L. A. de (1994) “(A vida entre parênteses)- o caso clínico como ficção”. In: Psicologia Clínica, vol.12, n.I, 2011.

STIGLITZ, G. La familia y la época, de um padre que no sea de semblante. In: Stiglitz, G. e Daumas, A. (orgs.) Psicoanálisis con niños y adolescentes 2- políticas, prácticas y saberes sobre el niño. Buenos Aires: Grama Ediciones, 2009, p. 109-111.

THIS, B. La Maison Verte - créer dês lieux d'accueil. Paris: Éditions Belin, 2007.

TORRES, M. La familia y el malentendido actual : madre sola y nuevas virilidades. In: GAVlOVSKI, E. J. e ULlOA, R. C. (orgs) Psicoanálisis e hipermodernidad. Venezuela: Editorial Pomaire, 2008, p. 199-208

. El analista como suplencia de lo real del padre. In: TORRES, M., FARAONI, J. e SCHNITZER, G. (orgs.). Uniones Del mismo sexo - diferencia, invención y sexuación. Buenos Aires: Grama Ediciones, 2010, p. 171-176.

TORT, M. La psychanalyse et la normalization psychologique. In : NEYRAND, G. e DUGNAT, M. (orgs) Familles et petite enfance - mutations des savoirs et des pratiques. Editions Érés, 2006, p. 49-74.

Fin del dogma paterno. Buenos Aires: Paidós, 2008

VANIER, A. Lacan. Coleção figuras do saber. São Paulo: Estação Liberdade, 2005.

VENTURA, Z. 1968: O ano que não terminou. São Paulo: Editora Planeta do Brasil, 2008a.

1968: O que fizemos de nós. São Paulo: Editora Planeta do Brasil, 2008b.

VIDAL, P. Em tempo: sozinho, mas não sem os outros. In: Latusa digital. N. 23, ano 3, julho de 2006.

VOLPE, M. M. S.O.S. Família e Escola: um estudo sobre a mediação dos especialistas da subjetividade no processo educativo. São Paulo: Humanitas/FAPESP, 2011.

VOLTOLINI, R. Psicanalisar e educar ou Psicanálise e Educação? Um retorno a Freud (2009). Disponível no site Educação on line, no endereço eletrônico: 
http://www.educacaoonline.pro.br/index.php?option=com_content \&view=article \&id=3 37:psicanalisar-e-educar-ou-psicanalise-e-educacao \&catid=36:especial $\&$ Itemid $=46$.

WINNICOTT, D. W. Conversando com pais. São Paulo: Martins Fontes, 1999.

A família e o desenvolvimento Individual. São Paulo: Martins Fontes, 2001.

YUREVICH, R. Estructura. In: MILLER, J.-A. Scilicet: Semblantes y sinthome. Buenos Aires: Grama Ediciones, 2009, p.117-119.

ZENONI, A. Versões do Pai na psicanálise lacaniana: o percurso do ensinamento de Lacan sobre a questão do pai. Psicologia em Revista 15. Belo Horizonte, v. 13, n. 1, p. 15-26, jun. 2007. 